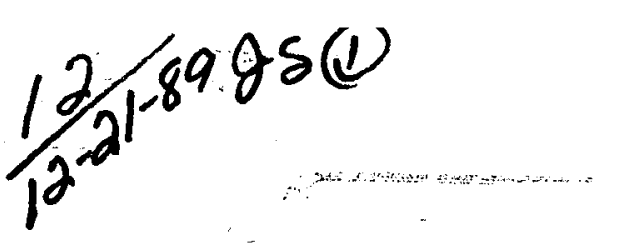

PNL-7131

UC-510

\title{
Nuclear Waste Treatment Program Annual Report For FY 1988
}

Compiled by

R. A. Brouns and J. A. Powell

November 1989

Prepared for the U.S. Department of Energy under Contract DE-AC06-76RLO 1830

Pacific Northwest Laboratory

Operated for the U.S. Department of Energy

by Battelle Memorial Institute

\section{Battelle}

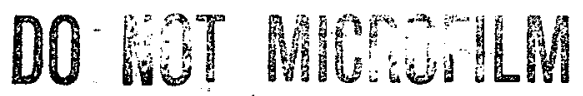

COVER 


\section{DISCLAIMER}

This report was prepared as an account of work sponsored by an agency of the United States Government. Neither the United States Government nor any agency Thereof, nor any of their employees, makes any warranty, express or implied, or assumes any legal liability or responsibility for the accuracy, completeness, or usefulness of any information, apparatus, product, or process disclosed, or represents that its use would not infringe privately owned rights. Reference herein to any specific commercial product, process, or service by trade name, trademark, manufacturer, or otherwise does not necessarily constitute or imply its endorsement, recommendation, or favoring by the United States Government or any agency thereof. The views and opinions of authors expressed herein do not necessarily state or reflect those of the United States Government or any agency thereof. 


\section{DISCLAIMER}

Portions of this document may be illegible in electronic image products. Images are produced from the best available original document. 


\section{DISCLAIMER}

This program was prepared as an account of work sponsored by an agency of the United States Government. Neither the United States Government nor any agency thereof, nor Battelle Memorial Institute, nor any or their employees, makes any warranty, expressed or implied, or assumes any legal liability or responsibility for the accuracy, completeness, or usefulness of any information, apparatus, product, or process disclosed, or represents that its use would not infringe privately owned rights. Reference herein to any specific commercial product, process, or service by trade name, trademark, manufacturer, or otherwise, does not necessarily constitute or imply its endorsement, recommendation, or favoring by the United States Government of any agency thereof, or Battelle Memorial Institute. The views and opinions of authors expressed herein do not necessarily state or reflect those of the United States Government or any agency thereof.

\section{PACIFIC NORTHWEST LABORATORY operated by \\ BATTELLE MEMORIAL INSTITUTE for the \\ UNITED STATES DEPARTMENT OF ENERGY under Contract DE-AC06-76RLO 1830}

\section{Printed in the United States of America}

Available to DOE and DOE contractors from the

Office of Scientific and Technical Information, P.O. Box 62, Oak Ridge, TN 37831; prices available from (615) 576-8401. FTS 626-8401.

Available to the public from the National Technical Information Service, U.S. Department of Commerce, 5285 Port Royal Rd., Springfield, VA 22161.

NTIS Price Codes, Microfiche A01

\begin{tabular}{cc}
\multicolumn{2}{c}{ Printed Copy } \\
& $\begin{array}{c}\text { Price } \\
\text { Pages }\end{array}$ \\
\hline $001-025$ & Codes \\
$026-050$ & A02 \\
$051-075$ & A03 \\
$076-100$ & A04 \\
$101-125$ & A05 \\
$126-150$ & A06 \\
$151-175$ & A07 \\
$176-200$ & A08 \\
$201-225$ & A09 \\
$226-250$ & A10 \\
$251-275$ & A11 \\
$276-300$ & A12
\end{tabular}

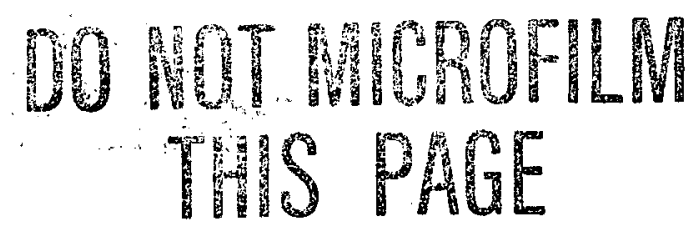


PNL- -7131

DE90 004982

\title{
NUCLEAR WASTE TREATMENT PROGRAM \\ ANNUAL REPORT FOR FY 1988
}

\author{
Compiled by \\ R. A. Brouns and J. A. Powe 11 \\ Contributing Task Managers \\ W. A. Ross \\ L. K. Holton, Jr. \\ S. C. Slate
}

Contributing authors are listed at the beginning of sections.

November 1989

Prepared for

the U.S. Department of Energy

under Contract DE-AC06-76RL0 1830

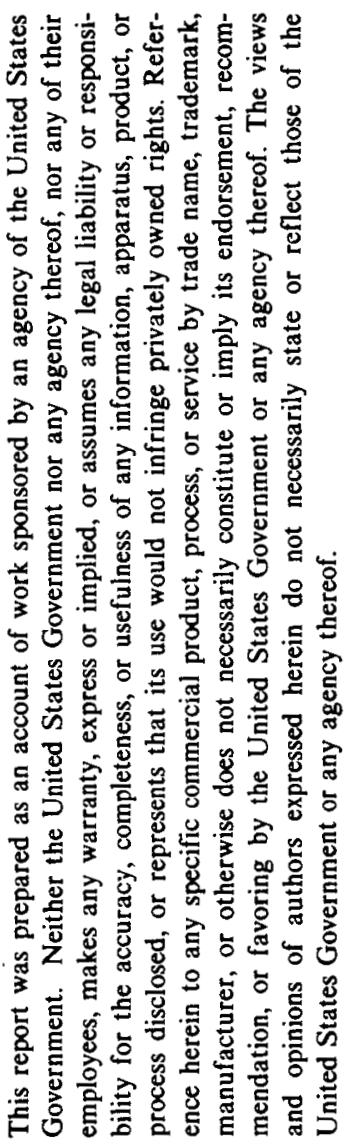

Pacific Northwest Laboratory

Richland, Washington 99352 


\section{EXECUTIVE SUMMARY}

\section{WEST VALLEY SUPPORT}

Much emphasis continues to be on the transfer of remote design technology for components integral to the West Valley Demonstration Project's (WVDP) vitrification process. In addition to preparing equipment specifications and drawings, Pacific Northwest Laboratory (PNL) staff also participated in numerous design coordination meetings and reviews of drawings prepared by other WVDP contractors. Nearly 200 jumper drawings for the vitrification cell were prepared by this program in FY 1988 . The remote jumpers connect vessels in the cell to each other for the transfer of solutions and provide for the flow of materials, instrumentation signals, and power from outside the cell. Analysis required in preparing the jumper designs involved balance, thermal stress, seismic, set-down stress, and displacement calculations.

Design efforts were begun on the canister decontamination and swipe station and on the remote maintenance station. Equipment selection and layouts of the vitrification off-gas treatment system, including a reamer to remotely clean the melter off-gas line, were finalized. Also finalized were the designs for the high-efficiency particulate air (HEPA) filter assemblies for heating, cooling and air conditioning of the vitrification cell.

Modifications to the waste feed slurry pump and the backup remote slurry sampler were completed. Conceptual designs for two alternative viewing systems to monitor the radioactive glass stream during filling of canisters were prepared as part of a feasibility study. The viewing system for the inside of the melter was fabricated, functionally tested in a remote mockup, and delivered to West Valley Nuclear Services. Conceptual drawings and engineering design criteria were issued for the suction canister that will be used to empty the melter at the end of the vitrification campaign.

Samples of actual West Valley high-level radioactive waste were received and characterized. Laboratory process tests duplicating the planned sludge washing, ion-exchange and blending steps for the project were conducted. other support work included preparation of a vitrification process 
description document, a detailed testing plan identifying and prioritizing the testing needs at West Valley to prepare for startup of vitrification, and review of the supernatant treatment system operations. Analysis and documentation of the mixing capability tests for the melter feed system were completed. Software used in mass balance calculations for the vitrification flowsheet was developed.

Support for the product qualification activities continued. A statistically designed study was completed that prepared and tested a set of glasses representing the expected range of operational variability in waste and glass composition. This work is providing data to build a statistical model of the leachability of the glass as a function of its chemical composition.

\section{FABRICATION OF ISOTOPIC HEAT AND RADIATION SOURCES}

Production of the 32 heat and radiation source canisters for the Federal Republic of Germany (FRG) was completed and reported in FY 1987. In addition, facility preparations were completed to install the equipment needed for canister closure, leak checking, decontamination, characterization, and storage. Functional testing and installation of this equipment were completed in early FY 1988, and approval to begin canister processing was obtained. The canisters were lid-welded using a gas tungsten arc welding process, and leak-tightness of the lid weld was verified by a helium leak test technique. Electropolishing technology was used to decontaminate the leak-tight canisters. All canisters easily passed both leak tightness and decontamination criteria. More specifically, the requirement for leak tightness was surpassed by roughiy a safety factor of 10 , and the decontamination criterion was surpassed by about a safety factor of 100 .

Surface temperature measurements, radiation exposure rates, gamma energy scanning, canister mass determination, and gauge testing were all completed as part of the characterization effort. A11 canister processing operations were completed well ahead of schedule due to the excellent performance of the equipment. The canisters are currently in storage at PNL. 


\section{LOW-LEVEL WASTE COORDINATION}

A design guide to allow engineered sorbent barrier technology to be applied to any low-level waste (LLW) site was drafted and is scheduled for publication in 1989. Additional adsorption behavior data on clinoptilolite and activated carbon were obtained. Previous testing had identified these as good candidates for engineered sorbent barriers because adsorption performance was good and the cost relatively low.

The Special Waste Form Lysimeters - Arid Program consisted of two studies in FY 1988. One study involved geochemical modeling of laboratory experiments to investigate the performance of solidified LLW in a typical arid, near-surface disposal site. The other study involved continuing to collect radionuclide release data from the lysimeter field facility where 200-L concrete, polymer and bitumen waste forms have been buried and exposed to leaching by water from natural precipitation since 1983. Two topical reports were issued covering the modeling work and analysis of the field data.

A document was submitted to the National LLW Management Program Office describing the development of site-specific DOE LLW radioactive waste classification systems based upon performance assessments of intruder scenarios.

\section{DOCUMENTATION OF NUCLEAR WASTE TREATMENT PROGRAM TECHNOLOGY}

Documentation of work related to the liquid-fed ceramic melter process for high-level waste treatment continued. Fourteen formal reports and professional meeting presentations were completed as part of this effort.

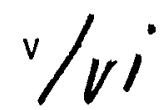




\section{CONTENTS}

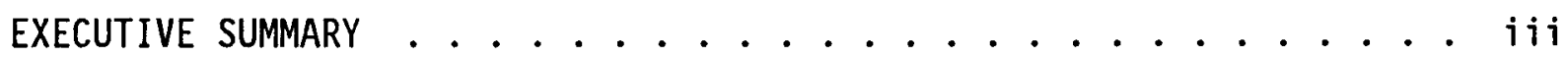

1.0 WEST VALLEY SUPPORT . . . . . . . . . . . . . 1.1

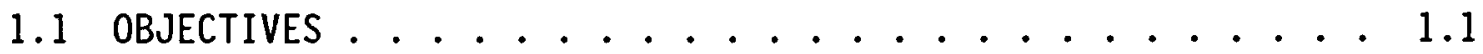

1.2 SUMMARY . . . . . . . . . . . . 1.1

1.3 REMOTE TECHNOLOGY SUPPORT . . . . . . . . . 1.3

1.3.1 Remote Jumpers .............. 1.3

1.3.2 Remote Process Components . . . . . . . . . 1.12

1.3.3 Auxiliary Remote Equipment ......... 1.21

1.3.4 Infrared-Television Melter Viewing System . . . 1.26

1.3.5 Suction Canister System . . . . . . . . 1.34

1.4 PROCESS SUPPORT . . . . . . . . . . . . 1.37

1.4.1 Process Chemistry and Waste Characterization ... 1.37

1.4.2 WVNS Proposed Supernatant Treatment System
Operational Sequence . . . . . . . . 1.42

1.4.3 Vitrification System Test Plan ........ 1.44

1.4.4 Evaluation of Sources of Batch-to-Batch Variability in the West Valley Glass Composition ....... 1.53

1.4.5 Development of Vitrification Mass Balance Flowsheet .................. 1.56

1.4.6 WVDP Vitrification Process Description Document . . 1.58

1.4.7 Slurry Homogeneity Testing of the West Valley Melter Feed Tank and Sampler System ....... 1.59

1.4.8 Evaluation of Properties of Simulated West Valley Feed ............. 1.63

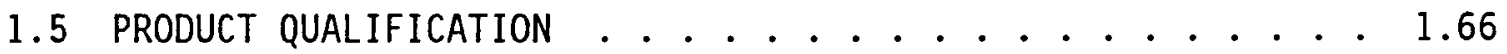

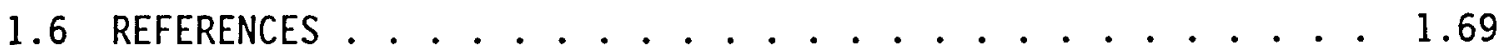

2.0 FABRICATION OF ISOTOPIC HEAT AND RADIATION SOURCES . . . . . 2.1 


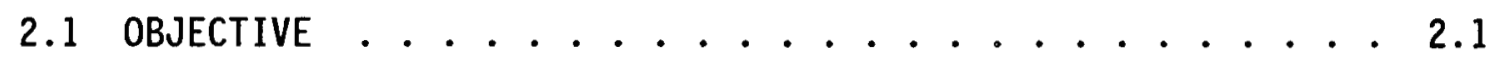

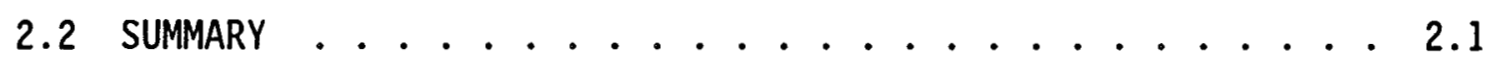

2.3 INTRODUCTION . . . . . . . . . . . . . . . 2.2

2.4 CANISTER ClOSURE . . . . . . . . . . . . . . . . . 2.4

2.4.1 Helium Capsule Filling . . . . . . . . . 2.5

2.4.2 Weld Preparation ........... 2.7

2.4 .3 Welding . . . . . . . . . . . 2.8

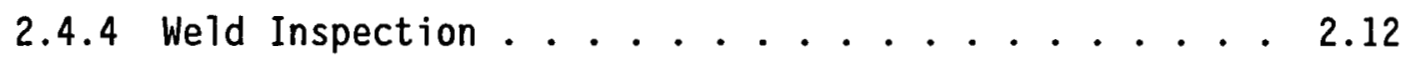

2.4 .5 Canister Rinsing . . . . . . . . . 2.12

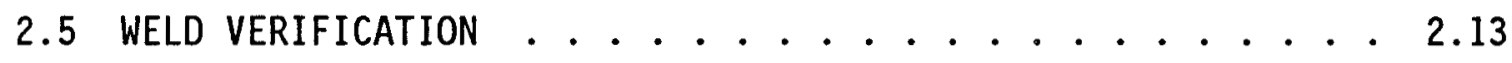

2.5.1 Gross Leak Check ............. . 2.13

2.5.2 Fine Leak Check . . . . . . . . . . 2.15

2.6 ELECTROPOLISHING . . . . . . . . . . 2.20

2.6.1 System Description ........... 2.20

2.6.2 Electropolishing Results ........... 2.25

2.7 CANISTER CHARACTERIZATION . . . . . . . . . 2.28

2.7.1 Exposure Rate Measurements . . . . . . . 2.29

2.7 .2 Temperature Scan ............ 2.33

2.7.3 Canister Weight Measurement . . . . . . 2.35

2.7.4 Canister Straightness and Ovality Test ..... 2.36

2.7.5 Gamma Scan ................ 2.37

2.8 REFERENCES . . . . . . . . . . . . . . . . 2.42

3.0 DOCUMENTATION OF NUCLEAR WASTE TREATMENT PROGRAM TECHNOLOGY . . . 3.1

4.0 LOW-LEVEL WASTE COORDINATION . . . . . . . . . . . 4.1

4.1 OBJECTIVES . . . . . . . . . . . . 4.1

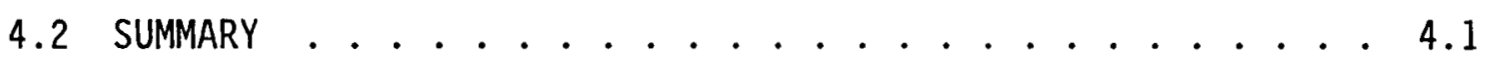


4.3 APPLICATION OF ENGINEERED SORBENT BARRIERS . . . . . . 4.2

4.3.1 Sorbent Barrier Design Guide ......... . 4.3

4.3.2 Laboratory Studies ........... . 4.10

4.3.3 Conclusion ............... 4.15

4.4 SPECIAL WASTE FORM LYSIMETERS - ARID . . . . . . 4.16

4.4.1 Geochemical Modeling of Laboratory Leach Tests . . 4 4.16

4.4 .2 Lysimeter Data . . . . . . . . . . 4.18

4.5 DOCUMENTATION OF INTRUDER SCENARIOS USED TO DEVELOP
SITE-SPECIFIC DOE LLW CLASSIFICATION SYSTEMS

4.5.1 Performance Objectives for LLW Disposal . . . . . 4.22

4.5.2 Review of Intruder Scenarios . . . . . . 4 4.23

4.5 .3 Discussion .............. 4.26

4.6 REFERENCES ................. . . 4.26 


\section{FIGURES}

1.1 Plan View of Vitrification Pit . . . . . . . . . . . 1.4

1.2 Typical Steam or Water Supply Jumper . . . . . . . . . 1.5

1.3 Steam Jumper with "S" Bend . . . . . . . . . . . . 1.5

1.4 Three-Way Connector . . . . . . . . . . . 1.6

1.5 Counterweight Designed To Balance Short Jumpers . . . . . 1.7

1.6 Thermocouple Design . . . . . . . . . . . . . . 1.7

1.7 Waste Header .................. 1.11

1.8 Vessel Vent Header . . . . . . . . . . . . . . 1.13

1.9 Key $\mathrm{P} 1$ an $8 \mathrm{Q}-1$ Pit .................. 1.14

1.10 Key Plan 8Q-2 Pump Pit ................ . . . . . . . . .

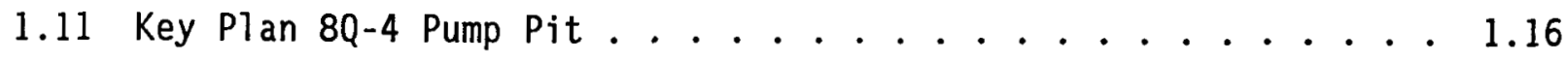

1.12 Key Plan 8Q-5 Diversion Pit . . . . . . . . . . 1.17

1.13 Canister Decon Station . . . . . . . . . . . . 1.18

1.14 HEPA Filter Housings ............... . 1.20

1.15 Remote Air Displacement S1 urry Pump . . . . . . . . . . 1.22

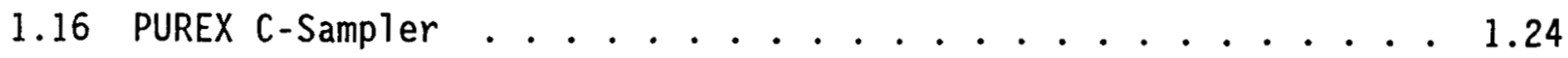

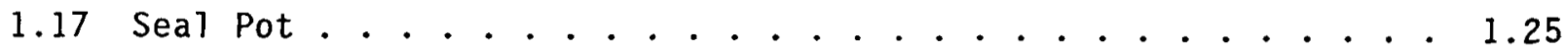

1.18 Glass Pour Viewing In-Cell Camera System . . . . . . . 1.27

1.19 Glass Pour Viewing Periscope System . . . . . . . . . 1.27

1.20 West Valley Nuclear Services Melter Viewing System . . . . . 1.28

1.21 Air and Steam Systems for Melter Viewing System . . . . . 1.29

1.22 Optical Path of Melter Viewing System .......... 1.30

1.23 Test System Arrangement . . . . . . . . . . . . 1.31

1.24 Cold Face View of the Mockup Test Stand . . . . . . . . 1.32 
1.25 Hot Face View of the Mockup Test Stand . . . . . . . . 1.33

1.26 Suction Canister System . . . . . . . . . . 1.36

1.27 Schematic of West Valley Melter Feed Tank . . . . . . . . 1.60

2.1324 Building Hot-Cell Complex ............ 2.5

2.2 Helium Source Capsule . . . . . . . . . . . 2.6

2.3 Helium Capsule Filling Manifold . . . . . . . . . 2.7

2.4 Remote Canister Lid Welder . . . . . . . . . . 2.9

2.5 Setting Parameters on Welding Power Supply ........ 2.10

2.6 Gow-Mac Gas Sniffer ................ 2.14

2.7 B-Cell Sniffer Arrangement . . . . . . . . . 2.15

2.8 Helium Leak Detection System . . . . . . . . . . 2.16

2.9 Helium Leak Test Being Performed . . . . . . . . . . . 2.17

2.10 Leak Detection Computation Results . . . . . . . . 2.19

2.11 Overhead View of the Canister Decontamination Cell . . . . 2.21

2.12 Canister Electropolishing System . . . . . . . . . 2.22

2.13 Retrieval of Canister from Electropolisher . . . . . . . 2.24

2.14 Radioactive Canister Before and After Electropolishing . . . . 2.26

2.15 Schematic of Exposure Rate Measurement System . . . . . . 2.29

2.16 Temperature Probe Equipment System . . . . . . . . . 2.35

2.17 Gamma Scan System . . . . . . . . . . . . 2.38

2.18 Gamma Scan of Normal Canister . . . . . . . . . 2.39

2.19 Typical Gamma Scan of RLFCM-8 Canister . . . . . . . . . 2.40

2.20 Gamma Scan of Canister with Void . . . . . . . . . 2.40

2.21 Gamma Spectrum of RLFCM Glass . . . . . . . . . . 2.41

Conceptual Design of a Sorbent Barrier in a Shallow
Land Burial Trench. . . . . . . . . . . . . . . . . 
4.2 Basic Design Steps for an Engineered Sorbent Barrier System . 4.4

4.3 Effect of $\mathrm{pH}$ on Sorption of ${ }^{85} \mathrm{Sr} . \ldots . . . . . . .4 .11$

4.4 Typical Adsorption Curve for (a) Strontium and (b) Magnesium . . 4.12

4.5 Effect of Contact Time on ${ }^{85} \mathrm{Sr}$ Distribution Coefficient . . . 4.13

4.6 Effect of Particle Size on Sorption of $85 \mathrm{Kr}$. . . . . . 4.14

4.7 Cumulative Release of Tritium from Lysimeters . . . . . . . 4.19

4.8 Cumulative Release of ${ }^{60}{ }^{\circ}$ from Lysimeters ......... . 4.19

\section{$\underline{\text { TABLES }}$}

1.1 Design Parameters for Jumpers to CTS Components . . . . . 1.9

1.2 Summary of Analytical Results for Sludge Samples . . . . . 1.39

1.3 Correlation of Testing Objectives and Testing Methods . . . . 1.46

1.4 Test Objectives, Priorities, Organizational Assignments, and Schedule ............... . . 1.49

1.5 Selected Factors and Levels for the Statistical Design of Simulation Runs .............. . 1.54

1.6 Batch-to-Batch Relative Standard Deviation Estimates for the Two Levels of Analytical and Sampling Uncertainty . . . . . 1.55

1.7 Results from Statistical Analysis of Elemental Concentration Data . . . . . . . . . . . . . 1.61

1.8 Summary of Property Ranges for West Valley Feed Simulants . . 1.64

1.9 Summary of Measured Values for West Valley Feed Simulants . . 1.65

2.1 Concentration of Constituents in Electrolyte Solution . . . . 2.27

2.2 Parameters To Convert Current to Exposure Rate at Room Temperature ................ 2.31

2.3 Measured Radiation Exposure Rates at Surface of

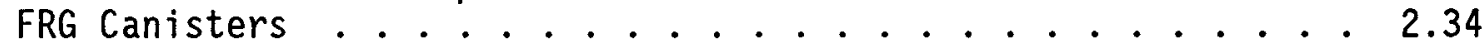

2.4 Canister Surface Temperature Summary, ${ }^{\circ} \mathrm{C} \ldots \ldots . . . . . .2 .36$ 
2.5 Summary of Canister Weight Data ............ 2.37

4.1 Distribution Coefficients of Selected Sorbent Materials . . . 4.6

4.2 Average Water Balance Parameters, cm . . . . . . . 4.18 


\title{
1.0 WEST VALLEY SUPPORT
}

\author{
W. A. Ross - Manager
}

\subsection{OBJECTIVES}

The Western New York Nuclear Services Center (WNYNSC) successfully reprocessed commercial nuclear fuel for five years until operations were terminated in 1972. Underground tanks at the site contain high-level waste ( $H L W)$ produced from the fuel reprocessing campaigns. Based on original agreements, the State of New York has assumed responsibility for these wastes. The Department of Energy (DOE) is assisting, through the West Valley Demonstration Project (WVDP), in retrieving and solidifying these wastes. The site contractor for the WVDP is West Valley Nuclear Services Co., Inc. (WVNS).

The overal1 objective of the West Valley Support Task (WVST) is to provide the technical support required by the WVDP, including the transfer of DOE-developed HLW treatment technology. Specific objectives include 1) providing characterization data that support the acceptability of the selected glass composition range, 2) assisting WVNS with the technology and equipment required to successfully vitrify the West Valley waste, and 3) providing support for the qualification of the West Valley process. The following sections summarize the FY 1988 activities of the WVST in support of these objectives.

\subsection{SUMMARY}

The WVST provided transfer of technology to the West Valley Support Project (WVSP) during FY 1988 in three major areas: remote technology design, process support, and product qualification.

Remote technology activities provided criteria and the remote design for components within the vitrification facility. During the past year a major emphasis was on design and analysis of remote jumpers which connect in-cel1 vessels to each other and provide for flow of materials or electrical signals and power from outside the cell to the process vessels. Design efforts were 
also begun on the canister decontamination and swipe station and on the maintenance station. The maintenance station is planned as the location where canisters filled with waste glass will be welded closed. The canister decontamination station will remove the condensed volatiles and other waste components from the canister surfaces. Since details on both of these operations are still being developed, the designs to date remain preliminary. The high-efficiency particulate air (HEPA) filter assemblies for heating, cooling, and air conditioning of the vitrification cell were designed, along with modifications to an air displacement slurry pump, and a mobile Csampler. Two alternative conceptual designs were prepared for a system to view the glass stream as it pours from the liquid-fed ceramic melter. A system for viewing the inside of the melter was fabricated, functionally tested, and provided to WVNS.

Process support activities are associated with equipment and process performance and operation. The major activities addressed during the year were: characterization and laboratory process testing of actual radioactive wastes from West Valley; preparation of a detailed testing $\mathrm{plan}$ which identifies and prioritizes the testing needs at West Valley; a review of the supernatant treatment system operations; evaluation of sources of variability in the final glass composition; development of a vitrification mass balance flowsheet; preparation of a vitrification process description document; testing of the mixing capability of the melter feed hold tank; and measurement of physical properties of simulated feeds.

Product qualification activities support the design of the waste product and the eventual preparation of the waste qualification report. A statistically designed study was completed which prepared and tested a set of glasses that represent the expected range of operational variability in waste and glass composition. The testing included the statistical design, the sample fabrication, the chemical durability testing, and the statistical analysis of the results to provide a model of the leachability of the glass as a function of its chemical composition. 
1.3 REMOTE TECHNOLOGY SUPPORT - J. M. Seay, D. N. Berger, R. L. Bogart, B. G. Place, R. E. Thornhill, and P. W. Zimmerman

The basic scope of work in this subtask was to provide remote design technology for components integral to West Valley's vitrification process. In general, unless the specific component was developmental or prototypical, the design was limited to defining component size, configuration, interfaces (e.g., nozzles and support attachments), and necessary remote handling features. The information was provided through drawings or input into WVNS equipment specifications. Final detailed design responsibility was passed on to the component fabricator. In conjunction with the design activities, Pacific Northwest Laboratory (PNL) provided technical assistance as deemed necessary by WVNS, including participation in design coordination meetings and review of drawings prepared by other contractors.

\subsubsection{Remote Jumpers}

Numerous designs for canyon remote jumpers were provided during FY 1988. Approximately 200 jumper drawings for the component test stand (CTS) equipment were prepared; five very detailed drawings were produced in support of these jumper drawings. Nearly all of these jumpers employed the time-tested and operational-proven PUREX connectors. Exceptions were several special thermocouple jumpers that had been proven during earlier development at PNL plus some 6-in. pipe jumpers on which the end connections had to be f1 anged.

\subsubsection{CTS Jumper Types and Functions}

Jumpers for the vitrification pit (Figure 1.1) covered a broad spectrum of types and functions although most were of the ordinary type that includes steam, water, air, power, or instrumentation. A steam and/or water supply jumper is usually a 2-in. pipe with 2-in. PUREX connectors (Figure 1.2). A steam jumper usually requires an " $S$ " bend to allow relief during thermal stressing (Figure 1.3). An air supply jumper is usually incorporated into a 2-in. three-way connector which consists of three 1/2-in. pipes held together with a strong back (Figure 1.4).

There were several specialty jumpers that provide service to the feed pump, sample pumps, feed jumper, and melter thermocouple jumpers. Two 


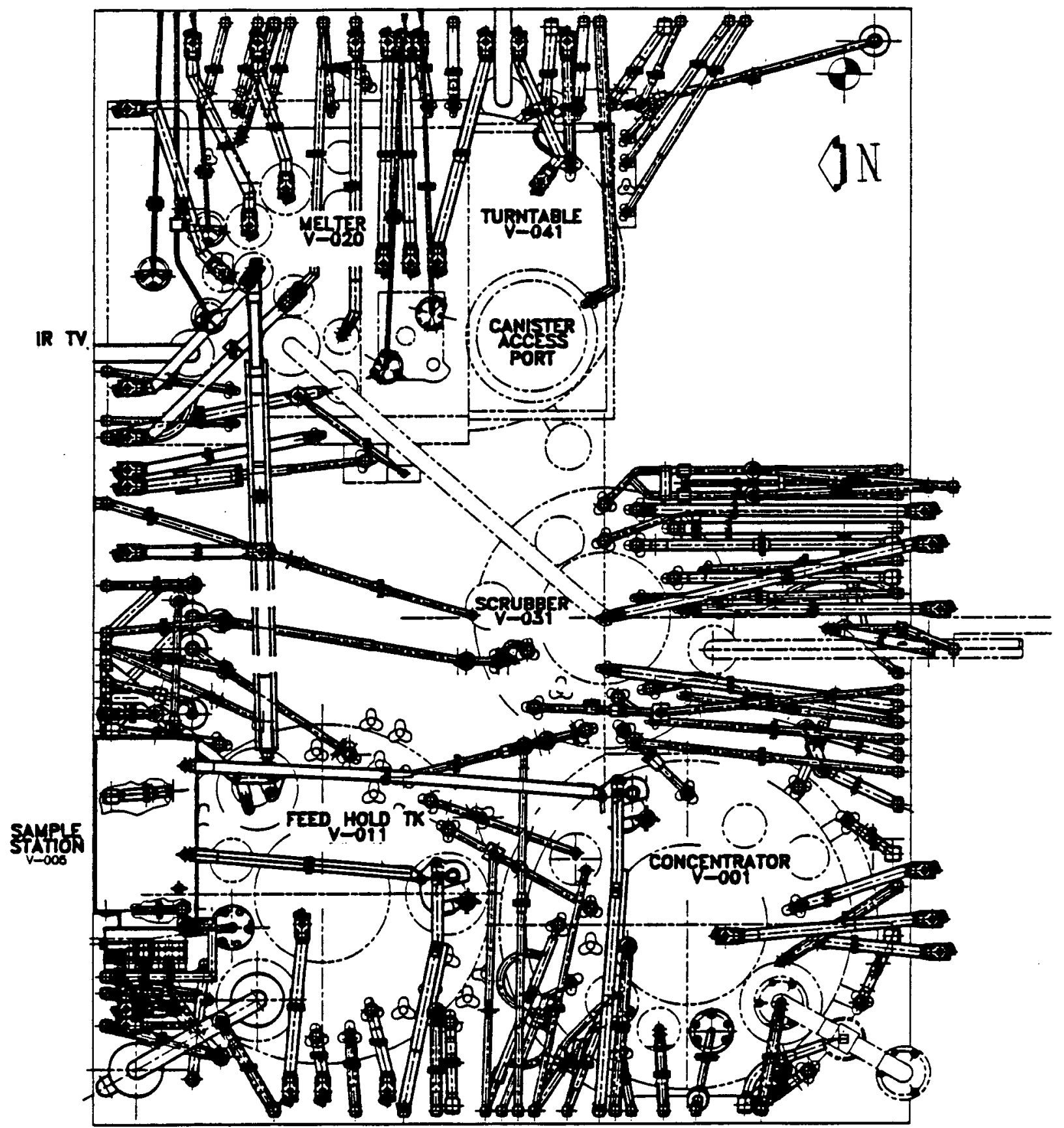

FIGURE 1.1. PIan View of Vitrification Pit 


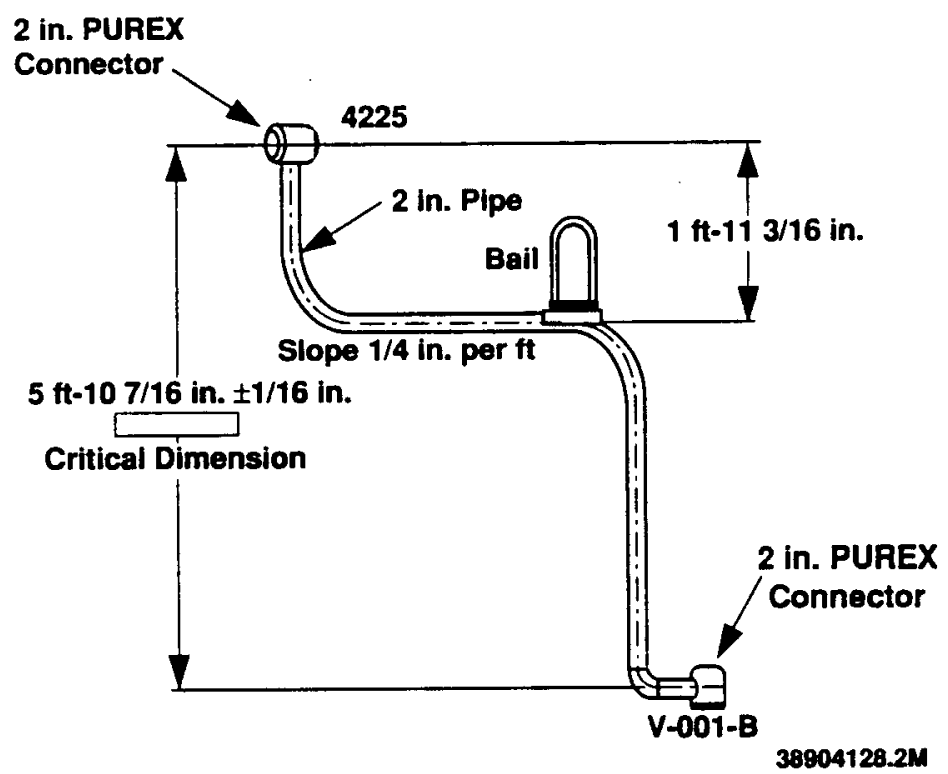

FIGURE 1.2. Typical Steam or Water Supply Jumper

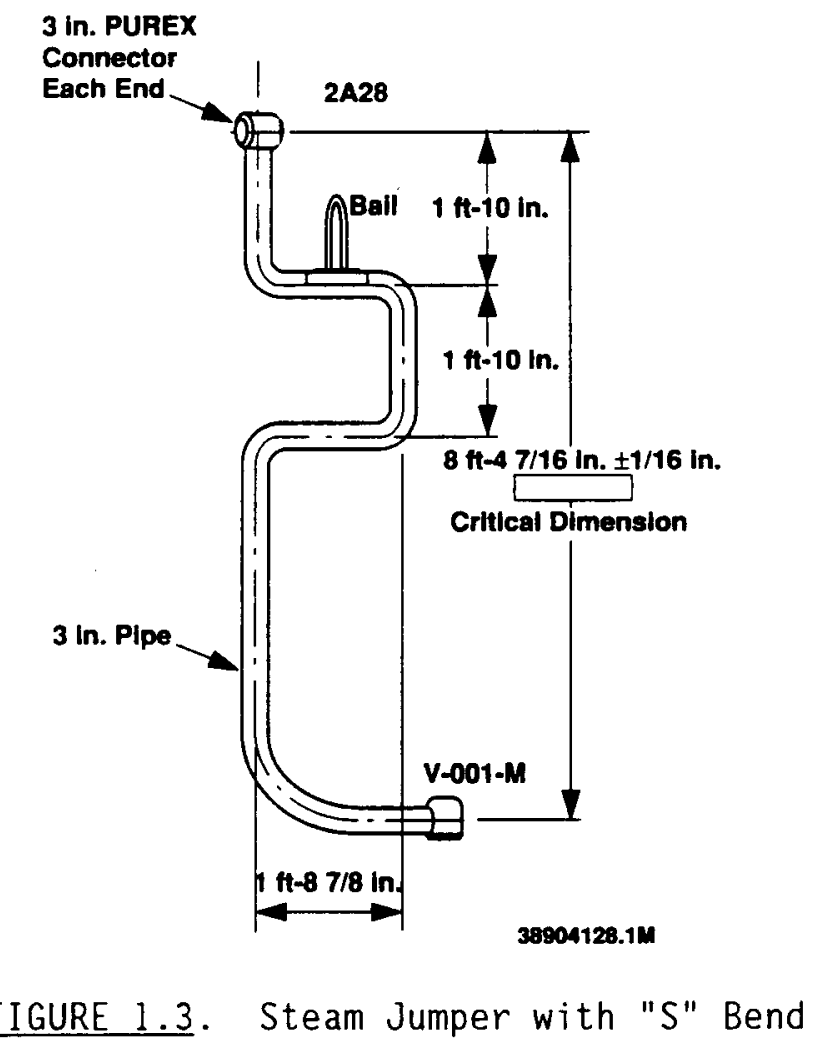

1.5 


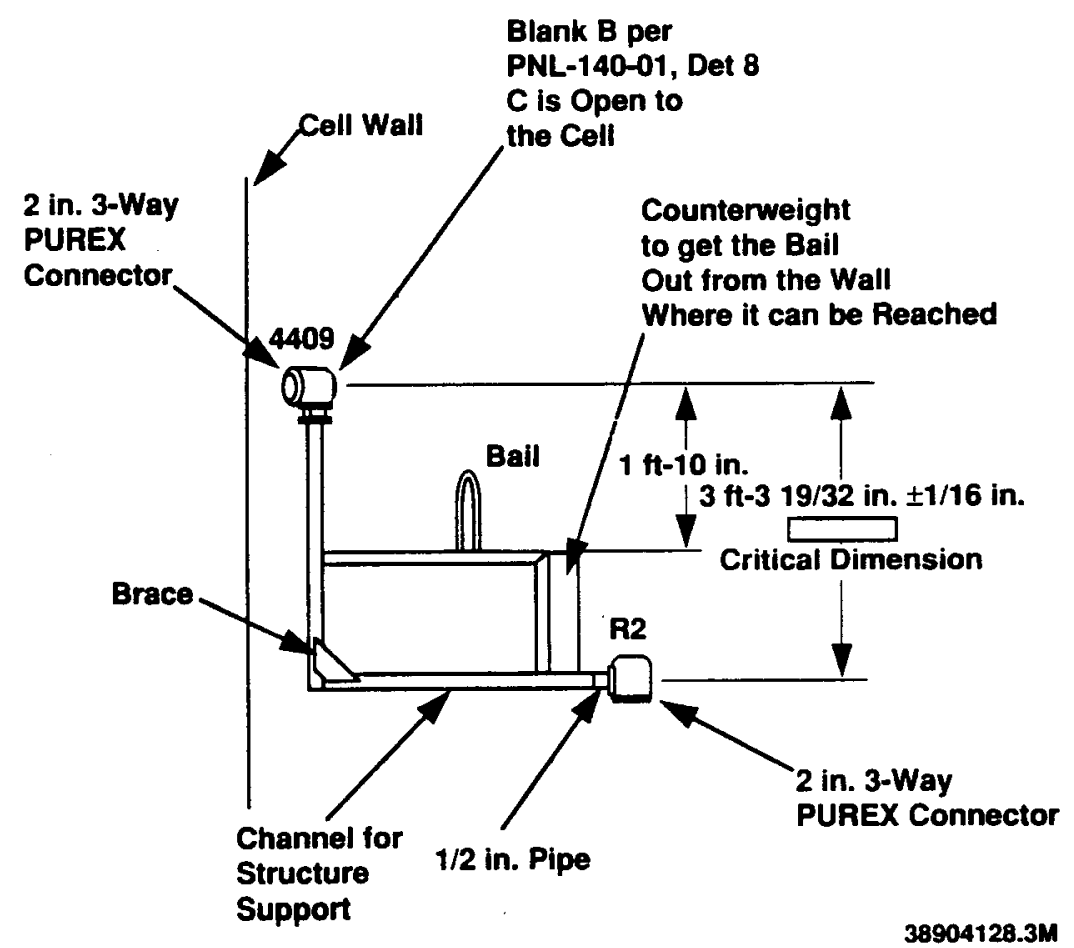

FIGURE 1.4. Three-Way Connector

jumpers have a design temperature above $600^{\circ} \mathrm{C}$, which requires the use of flexible connections. Other jumpers require the use of diaphragm-operated valves, jet ejectors, and canyon remote valves. As crane access is excluded 12 in. from the walls, and some jumpers are very short, a special counterweight design had to be developed to balance the jumper (Figure 1.5).

A thermocouple jumper design (Figure 1.6) was developed by PNL in a different program that is simply an open pipe which rests at a wall penetration and has the other end bolted to an equipment flange. The pipe serves as a guide to push a thermocouple through from the gallery into a thermowell within the equipment $f 1$ ange. When the pipe becomes filled with failed thermocouples, the in-cell crane is to remotely engage a clamp to contain the thermocouples. Then the pipe is removed with its thermocouples, and they are removed at a work station. This special pipe would then be returned to its original position, ready to receive other thermocouples. This design eliminates five bulky electrical jumpers in a very congested area. 


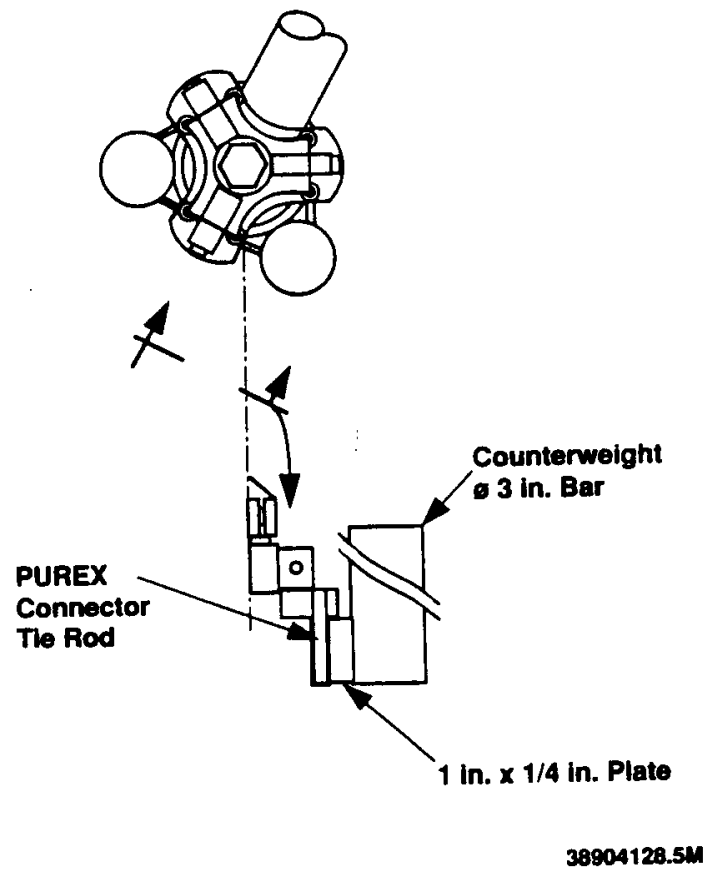

FIGURE 1.5. Counterweight Designed To Balance Short Jumpers

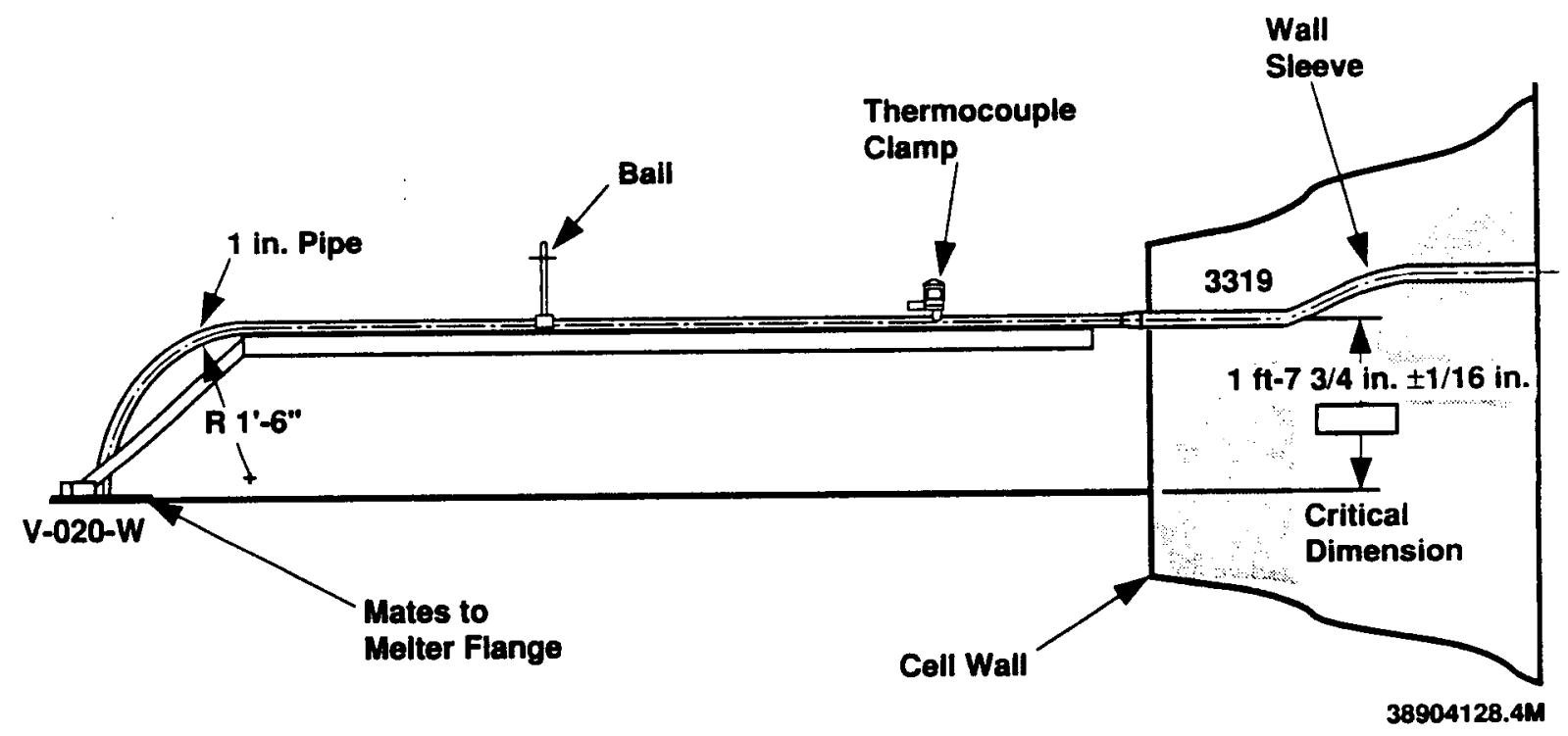

FIGURE 1.6. Thermocouple Design

Also during the testing program, the traditional bolt head-to-bolt head electrical connection within a PUREX electrical connector was replaced with a pin and socket type mating connection because of reported problems with 
arcing. This system was offered to WVNS for their implementation in the CTS facility, and they have decided to use it exclusively except for the connections to the agitator.

A 3-in. four-way PUREX connector was developed because of space restrictions in the feed system and because changes were not to be made in the baselined wall nozzle legend. Thus a four-way (1/2-in. pipe) connection in the 3-in. pipe size connector was designed.

\subsubsection{CTS Jumper Layout}

Jumpers were laid out in accordance with a wall matrix established in 1985 and with the function of the wall nozzle baselined in 1987. The equipment nozzles were assigned functions during the initial equipment design and fabrication that was established in 1985 and 1986.

Two service walls within the hot cell had to be created to provide jumper access to equipment due to the limited space on the walls next to the components. The stub wall, next to the recessed pit, provides 50 PUREX connectors and provides services to two tanks within the pit and to part of the off-gas system. The other created wall is the service wall; it provides 18 PUREX connectors that service the off-gas equipment in that vicinity.

\subsubsection{Jumper Design Parameters}

Table 1.1 lists the design parameters established for the jumpers that service the CTS components.

\subsubsection{Jumper Analysis}

A11 of the melter turntable and feed preparation system's jumpers, Rev. 0, have been analyzed for thermal, seismic and set-down stresses and for jumper connector displacement when the jumper is suspended by the crane. Analysis summaries were delivered to WVNS along with the drawings. The jumper analyses for the submerged-bed scrubber (SBS) and the off-gas system are being prepared. Jumper analyses consist of the following: 
TABLE 1.1. Design Parameters for Jumpers to CTS Components

Jumper Service

Chemical Addition

Cooling Water

Air (utility)

Air (instrument)

Steam/Condensate

Process

Off Gas

Off-Gas Heaters

Melter (off gas)
Pressure

80 psig

80 psig

100 psig

50 psig

100 psig

$100 \mathrm{psig}$

$-120 \mathrm{in} . \mathrm{wg} / 30 \mathrm{psig}$

-120 in. $w g / 30 \mathrm{psig}$

$-120 \mathrm{in.} w \mathrm{wg} / 30 \mathrm{psig}$
Temperature, ${ }^{\circ} \mathrm{C}$

99

43

37

37

170

170

120

185

343

- balance calculations

- thermal stress calculations

- seismic calculations

- set-down stress calculations

- displacement calculations.

Balance calculations locate the lifting bail to within $1 / 2$ in. of the center of gravity. Double-bail jumpers and vertical jumpers did not require balance calculations.

Thermal and seismic stress calculations for pipe jumpers were compared to ANSI B3I.3 code allowable stresses as specified. In the cases where two or more jumpers are connected, the connected assembly was analyzed. Electrical jumpers did not require thermal stress calculations.

Seismic stress calculations for electrical jumpers were compared to the yield point of the material. Values for seismic acceleration correspond to Uniform Building Code Zone III, with an importance factor of 1.5 and a vertical acceleration equal to two-thirds of the horizontal acceleration, as specified.

Set-down calculations simulate an operational scenario whereby one end of the jumper is set down on the floor or on a nozzle and the other end is leaning against a wall or piece of equipment. The end on the floor is treated analytically as a pin connection or a rigid anchor, while the other end is free to rotate and displace in the vertical plane but constrained in 
the horizontal planes. Stresses were compared to ANSI B31.3, "Basic Allowable Stresses in Tension." Set-down calculations were not done for very short jumpers or jumpers with long dip tubes.

Displacement is the deflection of the end of the jumper due to bending under its own weight when it is suspended by the crane. This does not include tilt due to imbalance. The displacement criterion is $1 / 4 \mathrm{in}$. in the horizontal and $1 / 2$ in. in the vertical, per agreement between WVNS and PNL.

Thermal and seismic stress analyses for pipe jumpers were performed using the AUTOPIPE ${ }^{\mathbb{M}}$ software package (Version 4.06). In cases of minimum dunnage, AUTOPIPE can be used for displacement and set-down stress calculations as well. Seismic stress, set-down stress, and displacement of jumpers with significant amounts of dunnage were analyzed with NISA II ${ }^{\mathrm{m}}$, a finite-element analysis software package.

\subsubsection{Waste Header Design}

Once the line size was established ( 3 in.) and all service connections were identified, the waste header was designed to connect the major in-cel1 components to vault tank $8 \mathrm{D}-3$. This header slopes $1 / 8 \mathrm{in.} / \mathrm{ft}$ until it exits the cell on the west wall at the 96-in. level. The waste header (Figure 1.7) has three branches; two can be flushed at their origins, and the third picks up the two sumps in the southwest corner of the cell. Some components require a trap, and others require a sophisticated seal pot with numerous indicators and flushing provisions. The major vessels also have provisions for ejecting their contents into this header, which snakes throughout the cell without a trap. The snake configuration is used to compensate for seismic and thermal stresses imposed on the header, which is hard-piped within the cell and lacks flex connections.

m AUTOPIPE is a trademark of Engineering Design Automation, Berkeley, California.

m NISA is a trademark of Engineering Mechanics Research Corporation, Troy, Michigan. 


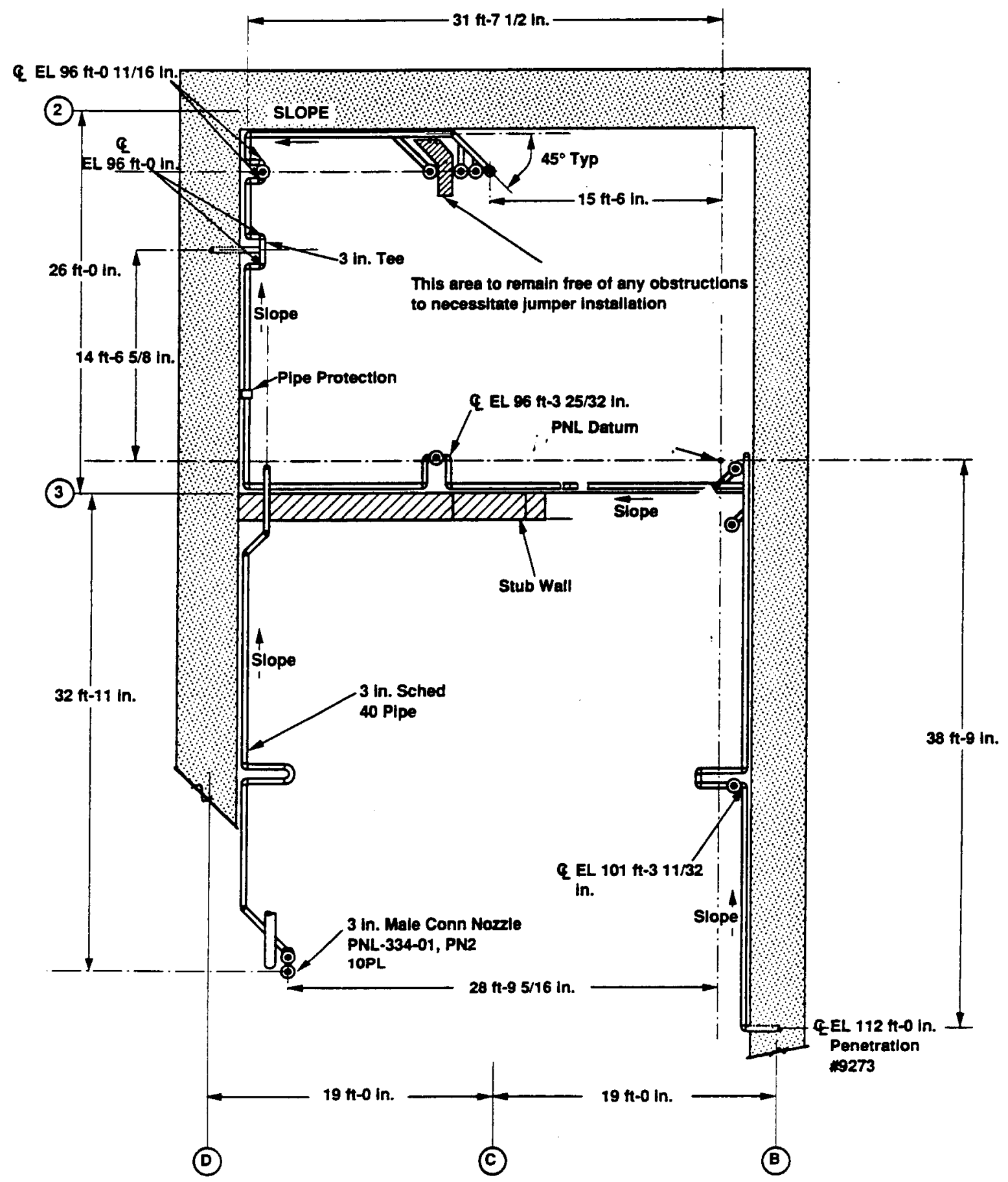

$38904128.9 M$

FIGURE 1.7. Waste Header 


\subsubsection{Vessel Vent Header}

A11 major components in the CTS cell are connected to a 6-in. hard-piped vessel vent header (Figure 1.8 ) located in a wall niche above all the vessels. The header has flex joints to offset thermal fluctuations and has flanges with pins and studs pointing up wherever a connection is made. It vents the decontamination station, the ceramic melter, and the feed preparation and feed hold tanks through the condenser. The vessel vent header slopes $1 / 8 \mathrm{in} . / \mathrm{ft}$ toward the condenser, into which it also drains; it serves also as an emergency outlet for the ceramic melter should the melter ever pressurize.

\subsubsection{Waste Mobilization Jumper Pits}

The design package for the waste mobilization jumpers, grinders, manifolds, and pump-mounting flanges was completed, and control was transferred to WVNS. The stress analysis was completed and transmitted to West Valley. The completed designs are shown in the four key plans: 1) 8Q-1 pit; 2) 8Q-2 pump pit, 3) 8Q-4 pump pit, and 4) 8Q-5 diversion pit (Figures 1.9 through 1.12).

The completed drawings reflect the changes required by the PNL and WVNS design reviews. The completed design package consisted of 48 drawings and four volumes of stress analysis data, one for each pit.

\subsubsection{Remote Process Components}

\subsubsection{0ff-Gas System}

The final issue of the vendor information drawings on the off-gas equipment was transmitted to WVNS.

The off-gas system begins at the ceramic melter. There the hot gases are partially cooled through a film cooler so that particulates will not stick to system walls. They are further cooled with 140 scfm of utility air prior to their descent into the scrubber, where the off gas is stripped of most of its particles and moisture. From there the remaining gaseous particles are once again stripped as they pass through a mist eliminator. From here the gases pass through a heater, a high-efficiency mist eliminator 


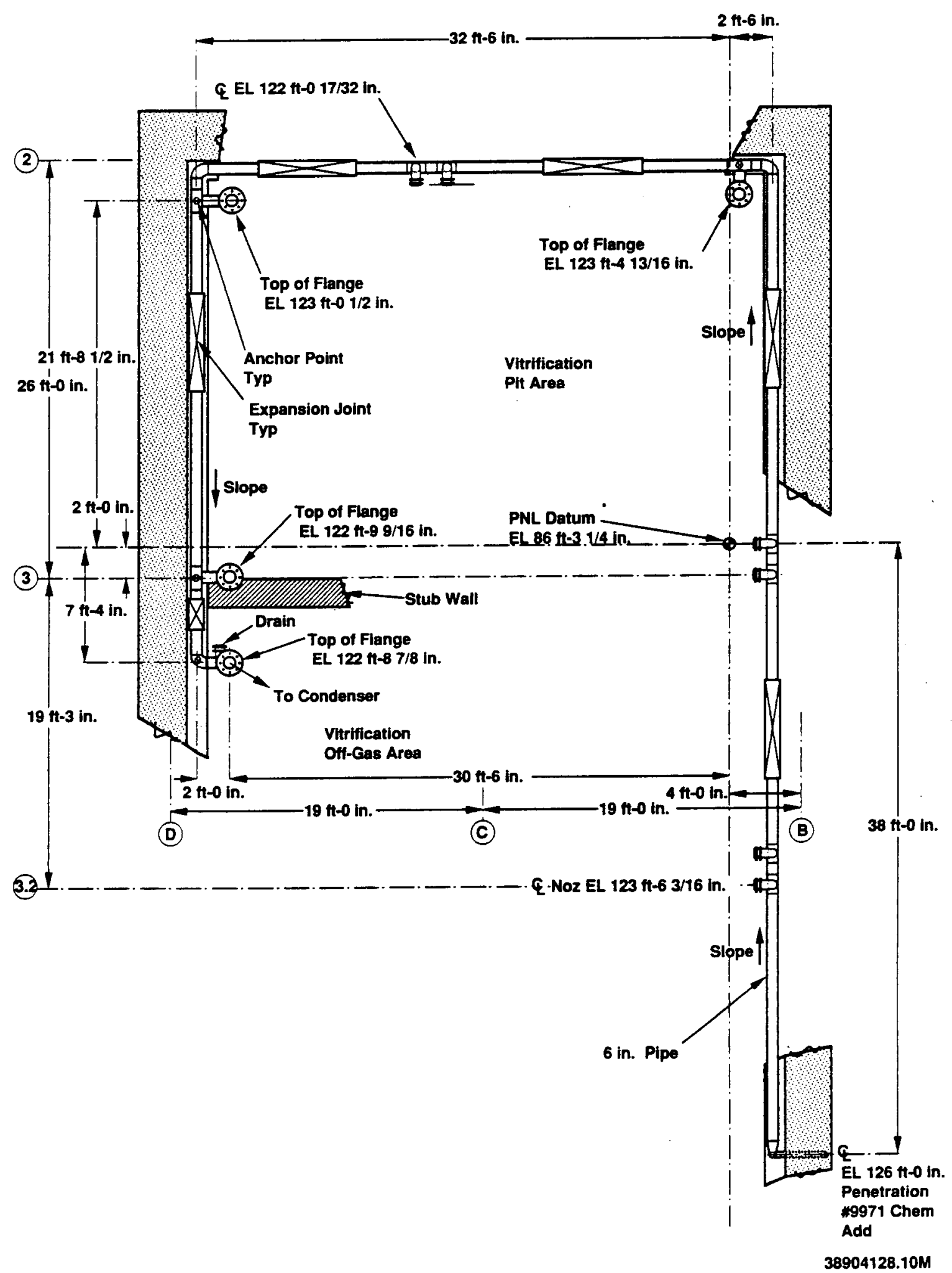

FIGURE 1.8. Vessel Vent Header 


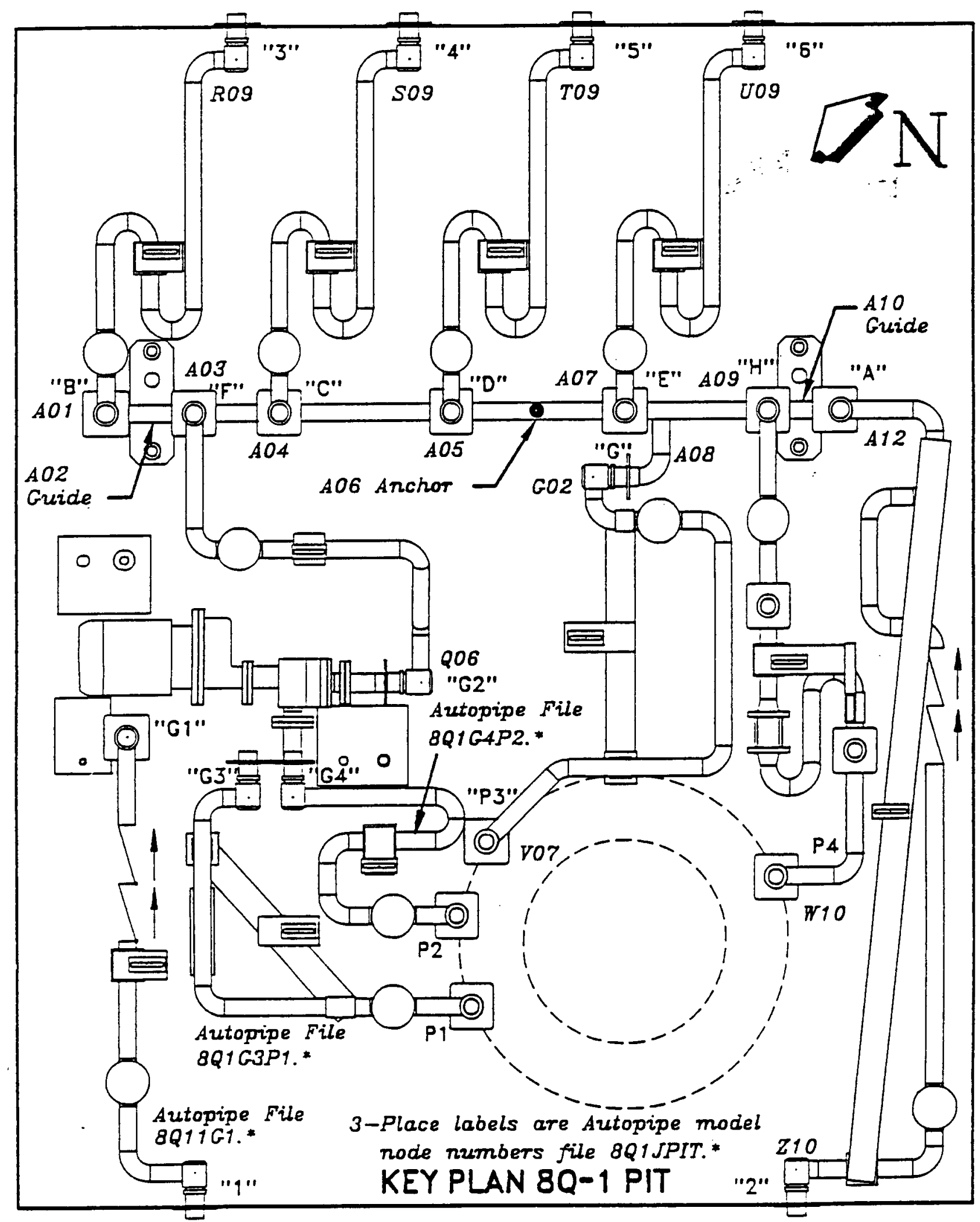

FIGURE 1.9. Key Plan 80-1 Pit 


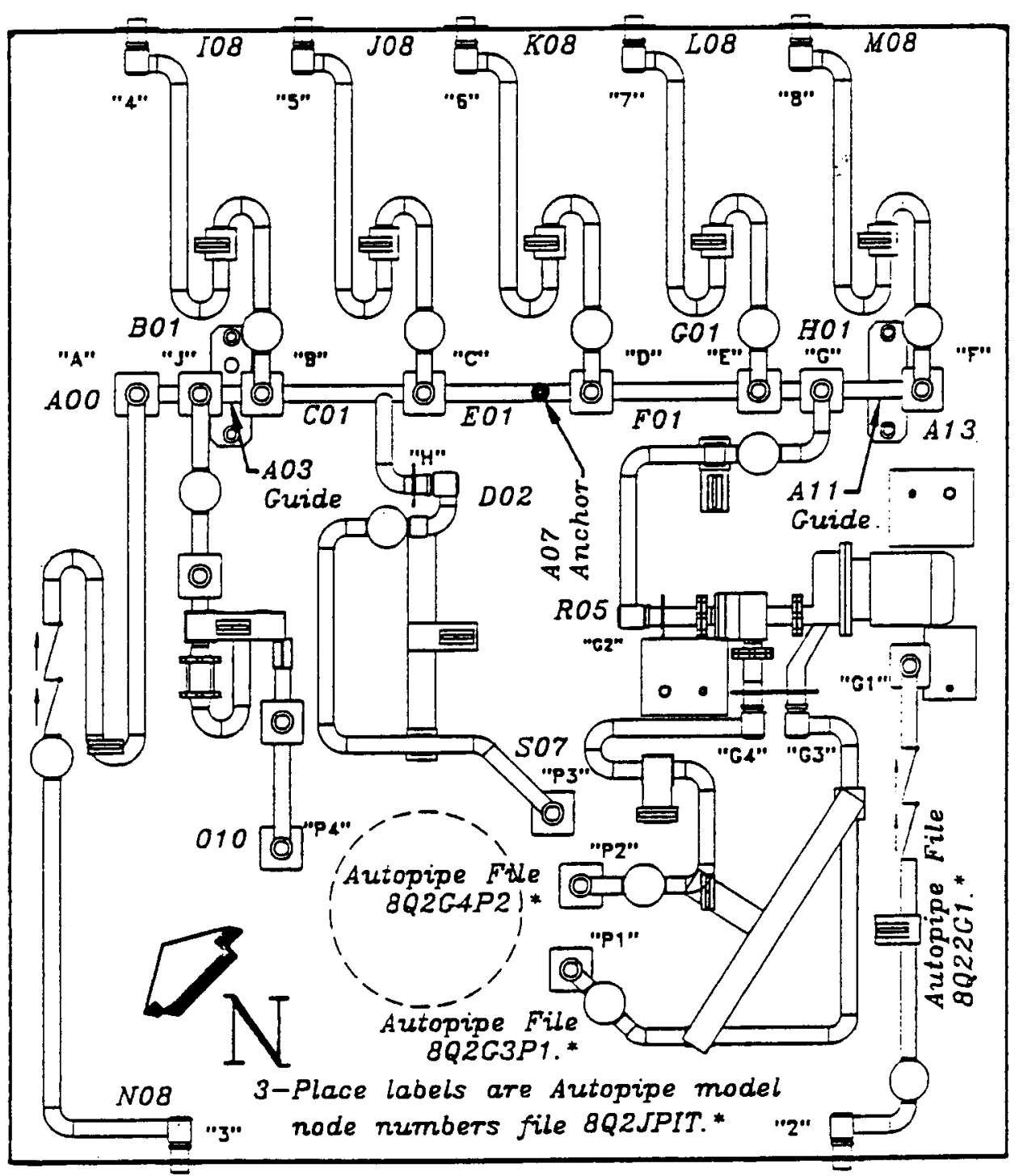

FIGURE 1.10. Key P1an 8Q-2 Pump Pit

(HEME), another heater, two HEPA filters back to back and then a postheater before exiting the cell and once again are filtered in the 01-14 Building before they exit from the stack.

The film cooler adjacent to the melter cavity contains an off-gas line reamer. The reamer is cycled during melter operation in an attempt to keep the throat clear of particulate and condensing semivolatiles so that the gases exit up through the spool piece and into the jumper leading to the SBS. 


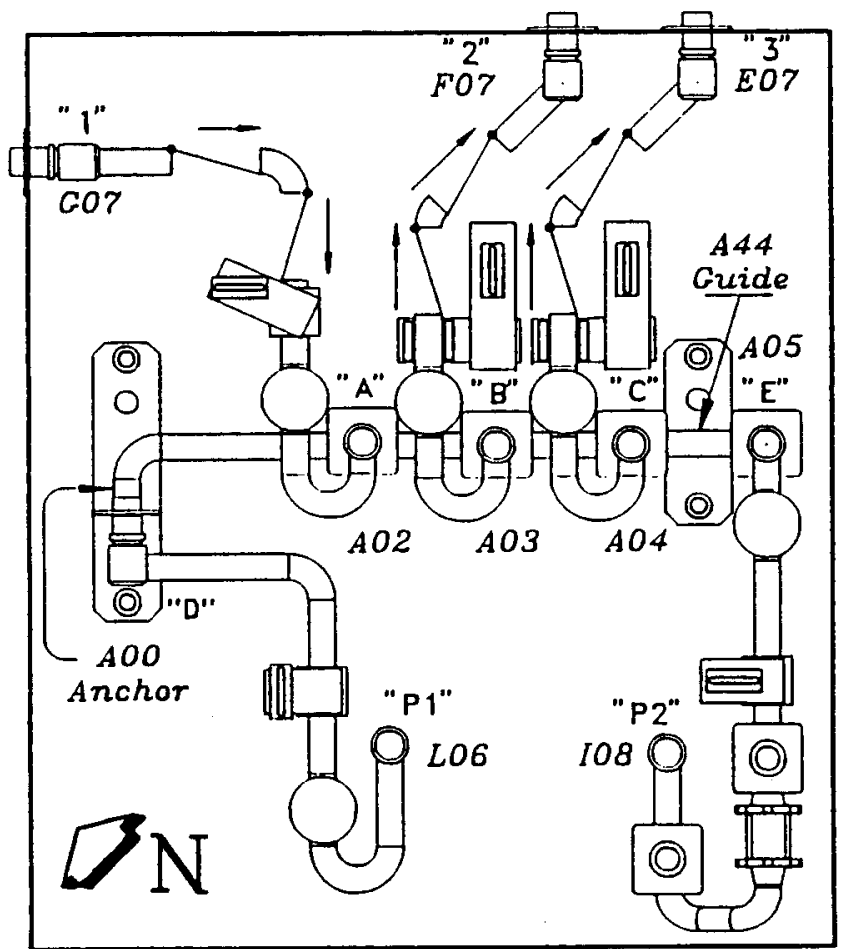

3-Place labels are Autopipe model

node numbers file BQ4JPIT.*

FIGURE 1.11. Key Plan 8Q-4 Pump Pit

After the first heater, the process off gas can pass through one of two trains, depending on which path is valved in. This option was provided so that one train could operate while the other was being repaired or some equipment replaced. HEPA filter assemblies will probably be replaced several times throughout the processing campaign.

The major lines between components of the off-gas system are 6-in. pipe, and since $6-i n$. PUREX connectors are not currently available or even designed, all of these connections are flanged. All flanged connections are horizontal, and the HEPA filters had to be placed at the top to preclude condensate draining into them. These two requirements caused the filters to be about $15 \mathrm{ft}$ high and thus required a structure for support and alignment of three heaters and two filters. 


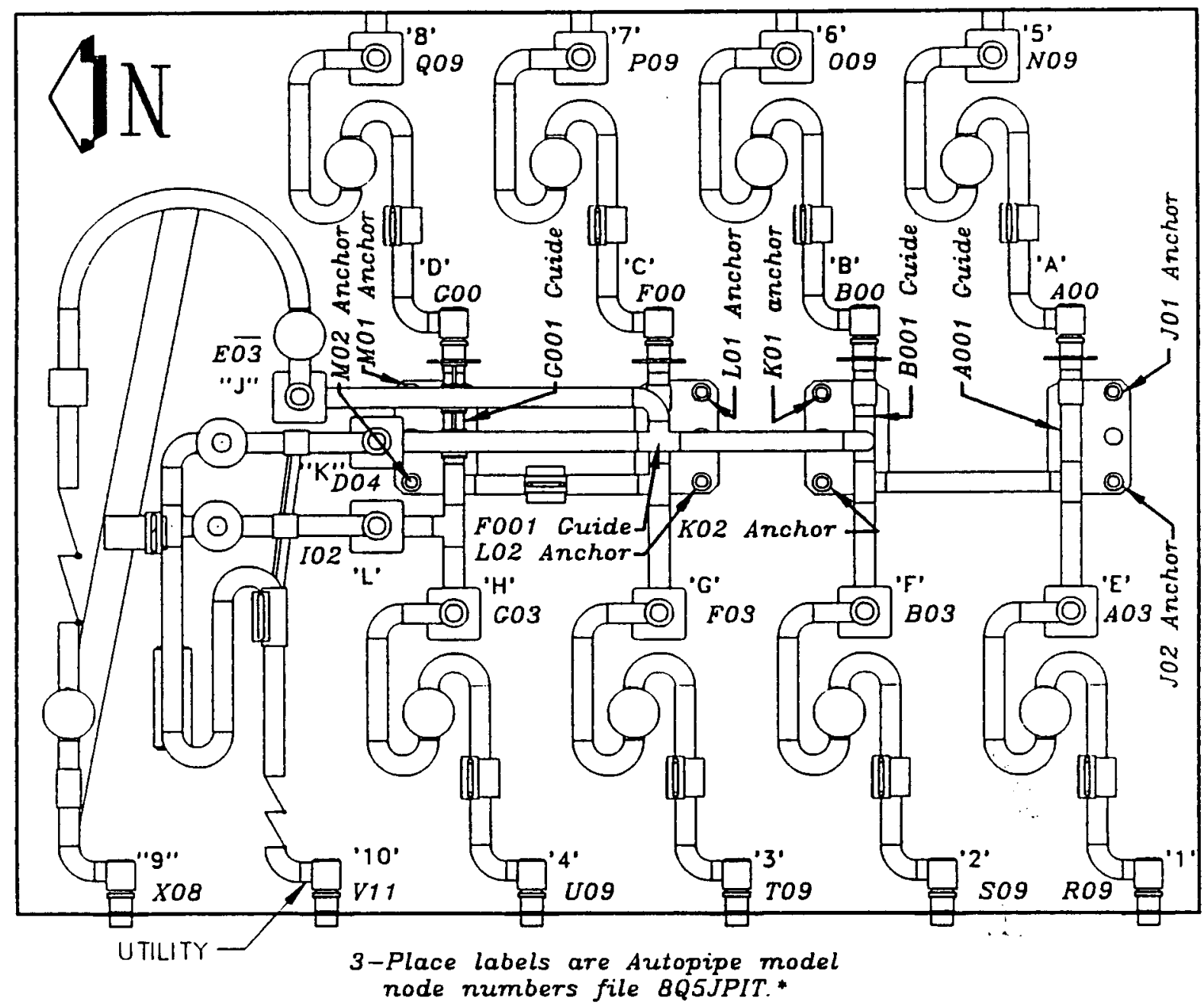

FIGURE 1.12. Key Plan 8Q-5 Diversion Pit

\subsubsection{Canister Decontamination and Swipe Station}

The decontamination station design is shown in Figure 1.13. Major accomplishments during 1988 include WVNS acceptance of design criteria, PNL design review, and preliminary design and specifications sent to WVNS ahead of schedule.

Decon station design reflects the change from a mechanical canister closure to a welded canister closure. The welded closure is superior in terms of reliability and is expected to cost about the same as, or less than, a qualified mechanical seal. The welded seal being considered is a 


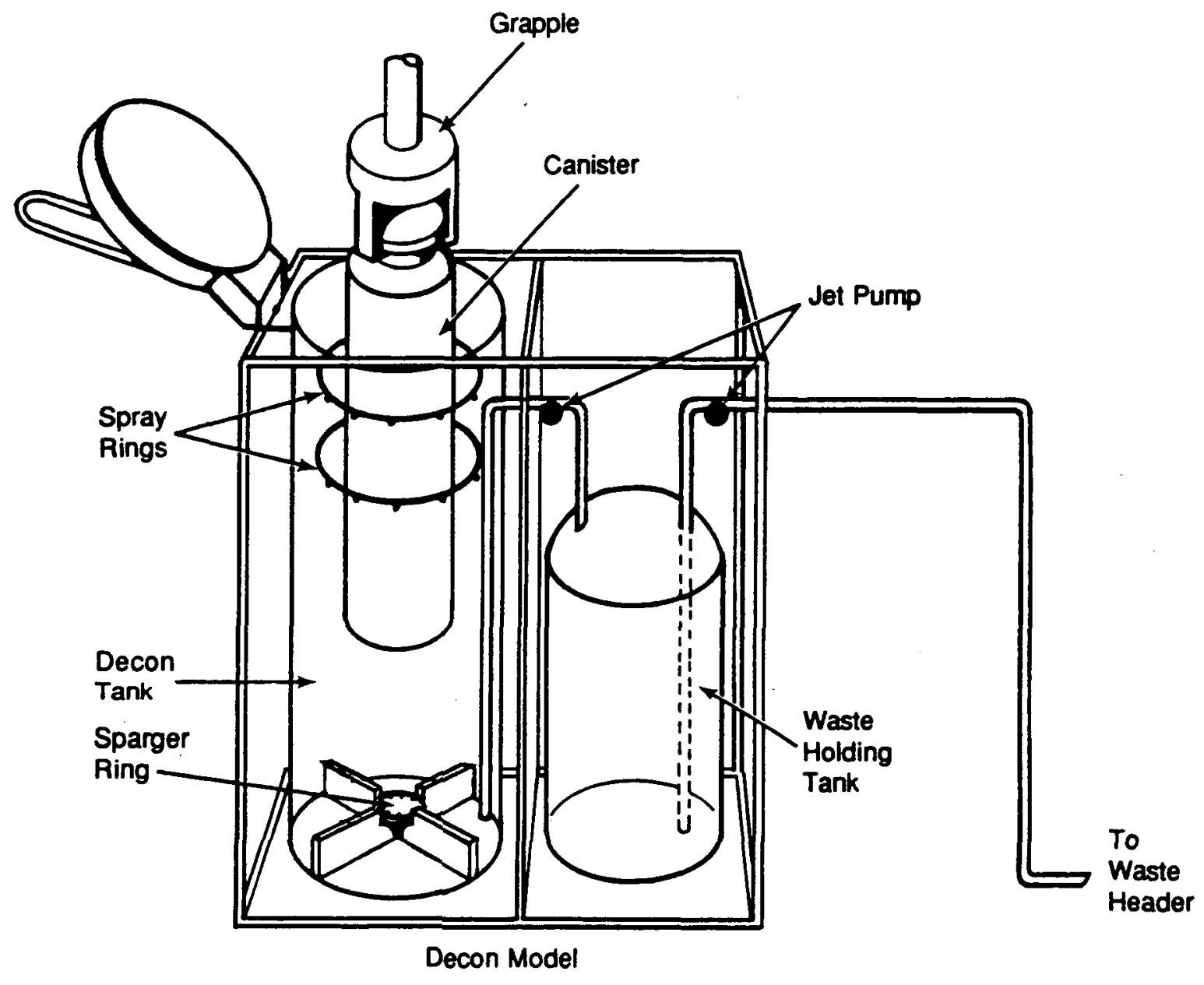

FIGURE 1.13. Canister Decon Station

"temporary" seal for decon. It would cover only about $1 / 4$ in. of the flange so that the decon fluid can clean the rest of the flange. Prior to shipping, a "permanent" or repository closure cap can be weided on, after the repository requirements are known. Glass samples would be taken before the "temporary" cap is installed to preclude the need to obtain them prior to shipment.

Other features of the design are remotely replaceable 1) upper spray rings and 2) decon tank lid. These features were added so that plugged spray rings or a damaged tank lid would not necessitate replacement of the decon module. 
The West Valley canister decontamination tank piping and instrumentation diagram (P\&ID) was red-lined, and corresponding comments on the P\&ID line list were sent to West Valley to correct discrepancies.

\subsubsection{Maintenance Station}

Design of the maintenance station is nearing completion. The design criteria were completed and sent to West Valley for approval. Comments were received from West Valley and incorporated into the design criteria, and approval to proceed with the design was given to PNL.

The drawings and the fabrication and installation specifications were completed and reviewed by PNL. The design package was transmitted to West Valley for review. Structural stress and seismic analyses were completed and are being included with the final deliverables.

\subsubsection{Heating, Ventilation and Air Conditioning HEPA Filters}

There are three banks of HEPA filters in the vitrificiation facility, each containing three $24 \times 24 \times 12$-in. filters, which are used as the primary exhaust filters for the vitrification cell. The filter housings were designed to use standard nuclear grade super-flow HEPA filters. The housings are located next to the south wall (Figure 1.14) of the CTS cell and are connected to three ducts protruding from the cell wall. Each housing has provisions for remote in-cell dioctyl phthalate (DOP) testing of the filter-to-mounting frame seals as well as $\triangle P$ measurement from the inlet to outlet of the housing. The housings with their filters were designed for an air flow of $3500 \mathrm{cfm}$.

To DOP-test HEPA filters that have been replaced remotely, a special diffuser is located upstream of the three filters. The diffuser provides uniform dissipation of the DOP droplets into the air stream. The polydispersed DOP is generated outside the cell by blowing compressed air through liquid DOP and exhausting the DOP through the special diffuser in the filter housing. The diffuser produces a cloud of DOP droplets with a lightscattering mean diameter of $\sim 0.7 \mu \mathrm{m}$. This provides for on- 1 ine DOP testing of the HEPA filter and seals within the enclosure housing. 

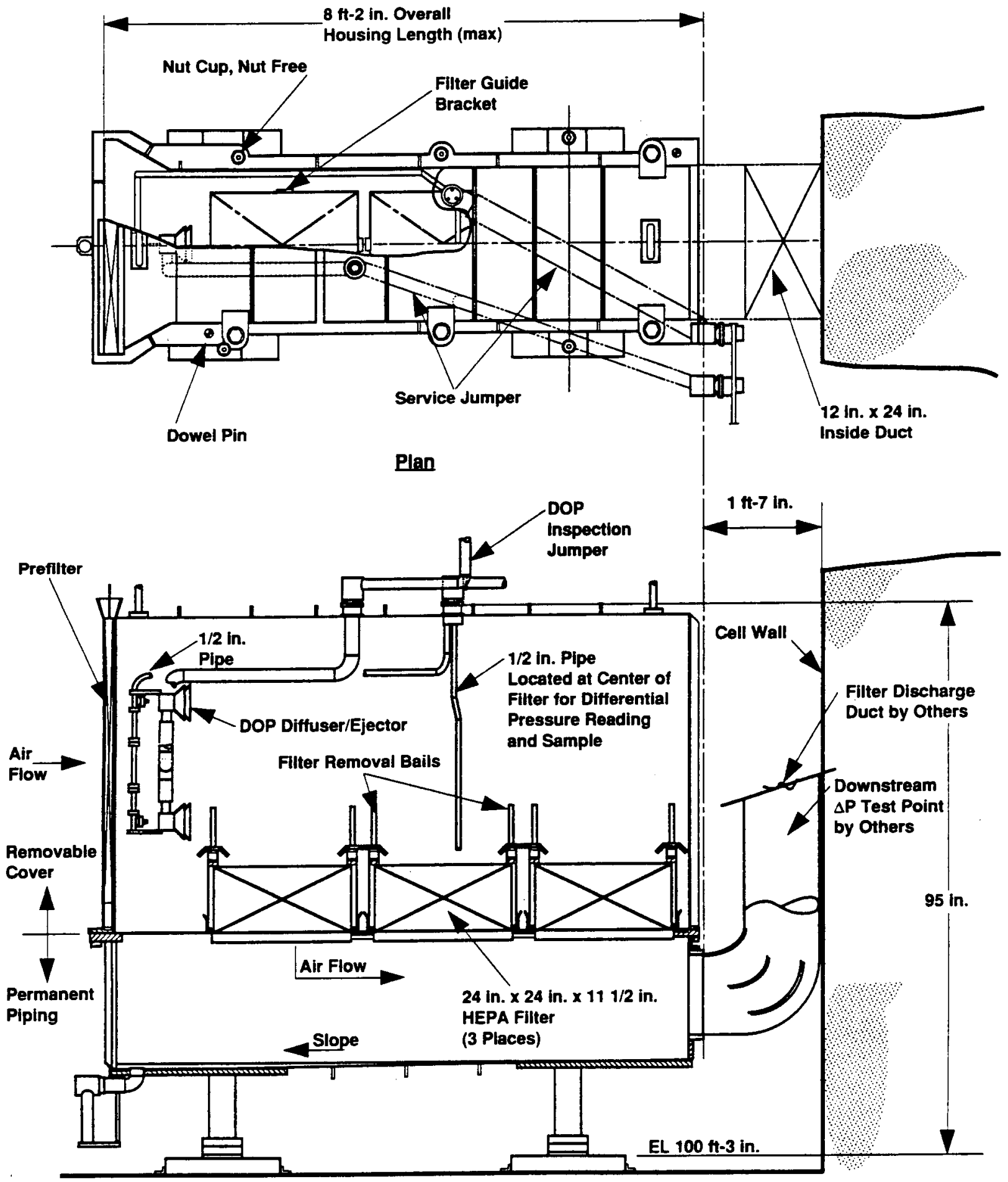

Elevation

38904128.11M

FIGURE 1.14. HEPA Filter Housings 
The housings are constructed of stainless steel and have remotely removable covers over the filters to protect them from accidental damage by falling objects. The covers and filters are installed and removed by means of the vitrification facility's process crane and impact wrench.

The design provided by PNL was a vendor's information drawing from which final detailed fabrication drawings could be produced. It contains all the key remote features necessary for canyon remote operations. A window on the west wall provides direct viewing of the filter's housing for maintenance and filter replacement.

\subsubsection{Auxiliary Remote Equipment}

\subsubsection{Off-Gas Line Reamer}

The off-gas reamer is to remove light material which may stick to the sides of the off-gas line. It is to prevent a buildup of material and blockage of the off-gas line.

The fabrication drawings and the fabrication, installation and operating specifications were completed. A PNL design review was held and the design package was sent to West Valley for their review.

\subsubsection{Air Displacement Slurry Pump Modifications}

The feed rate to the West Valley melter from the $V-011$ feed hold tank air displacement slurry (ADS) pump, Figure 1.15, needed to be increased to meet processing requirements. To accomplish this, the original ADS pump design feed rate capacity had to be increased $-50 \%$. This necessitated increasing the ADS pump chamber diameter and the chamber pressure. A modified ADS pump drawing showing the change to the pump chamber was provided to WVNS.

Calculations were performed to ensure that the cycle time and feed line diameter were not compromised. As a result of these calculations it was shown that $1 / 2-i n$. Sch. 40 pipe supplying the larger pump chamber was sufficient. The increased cycle time for the modified pump was $30.8 \mathrm{sec}$, which did not impact WVNS operational requirements. 


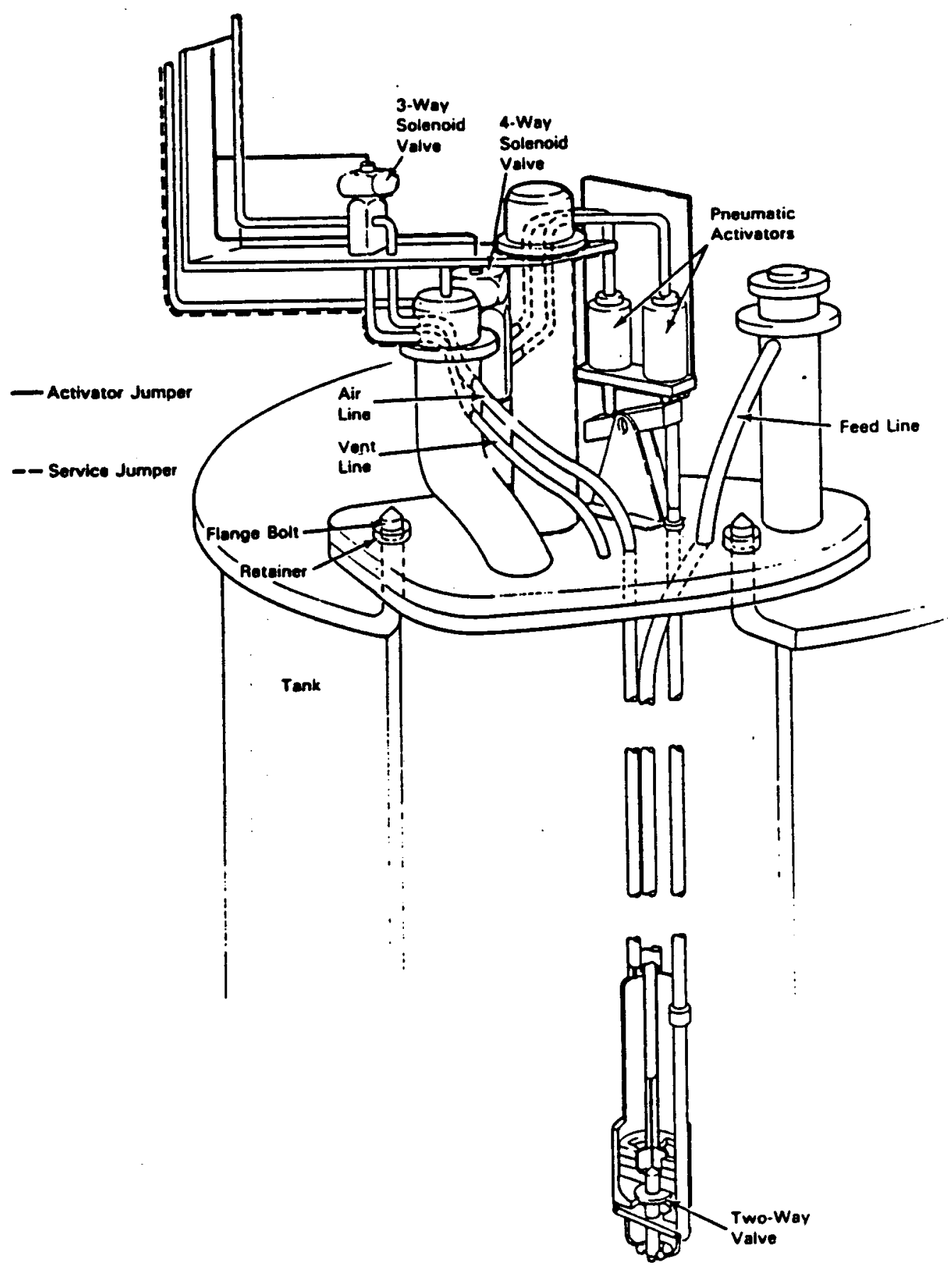

FIGURE 1.15. Remote Air Displacement Slurry Pump 


\subsubsection{C-Samplers}

The need to periodically sample the process vessel contents led to the development of a PUREX C-sampler connector (Figure 1.16) with a jet and a sample bottle incorporated in conjunction with the suction and return lines. A sample bottle is to be inserted under the jet and clamped in position at a sample station where manipulators are available. This PUREX assembly would then be transported and clamped to the appropriate vessel nozzle. After the air supply to the jet is turned on and the sample solution allowed to recirculate through the bottle for a specified time, the jet would be turned off and then the PUREX C-sampler assembly would be removed and brought to the sample station. There the sample bottle would be removed and sent to the laboratory for analysis. The sampler station contains provisions for flushing the PUREX C-sampler.

This scenario eliminates the need for an ADS sample pump in each vessel (each pump requires two support jumpers) and long, awkward jumpers to and from each vessel to the sample station. Despite all these advantages, however, a negative aspect is involved, the increased use of the in-cell crane.

PNL built the PUREX C-sampler, tested its remote aspects, and shipped the unit to WVNS for installation and functional testing in the CTS. Based on the testing, WVNS selected the Hydragard ${ }^{\circledR}$ sampling system, which the Defense Waste Processing Facility (DWPF) also plans to use as the main system. The Hydragard sampling system also is a recirculation type of system. The solution passes through a sample bottle for a time and then the diversion mechanism is retracted and the bottle is removed. The PUREX C-sampler will serve as a backup system in case of problems.

\subsubsection{Concentrator and Feed Hold Tank Seal Pots}

Both the concentrator tanks and the feed hold tank connect to the in-cell waste header via a seal pot (Figure 1.17). The final issue of the vendor information drawings for the two seal pots was transmitted to WVNS.

( $\quad$ Hydragard is a registered trademark of Hinds International, Inc., Hillsboro, Oregon. 


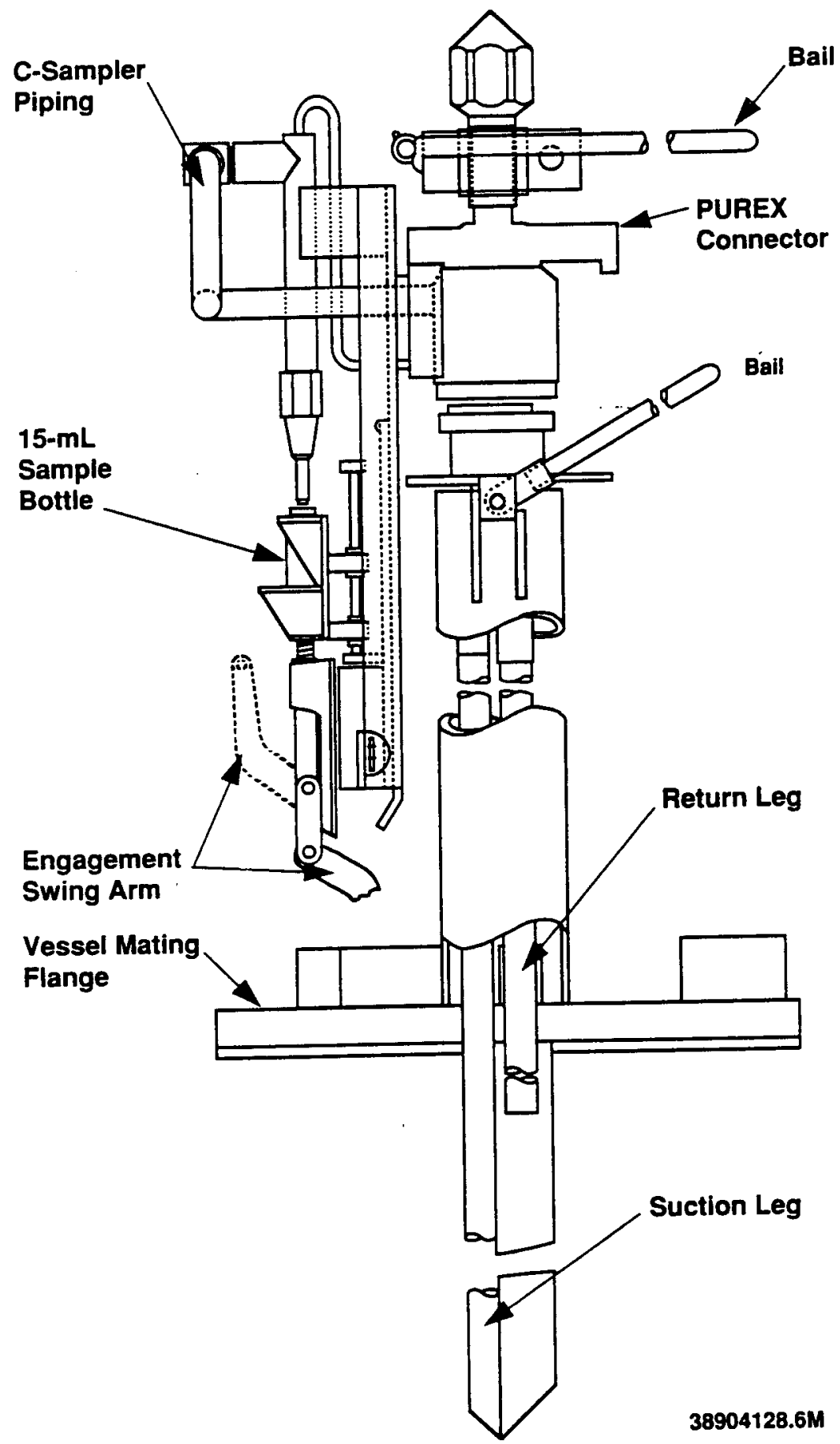

FIGURE 1.16. PUREX C-Sampler 


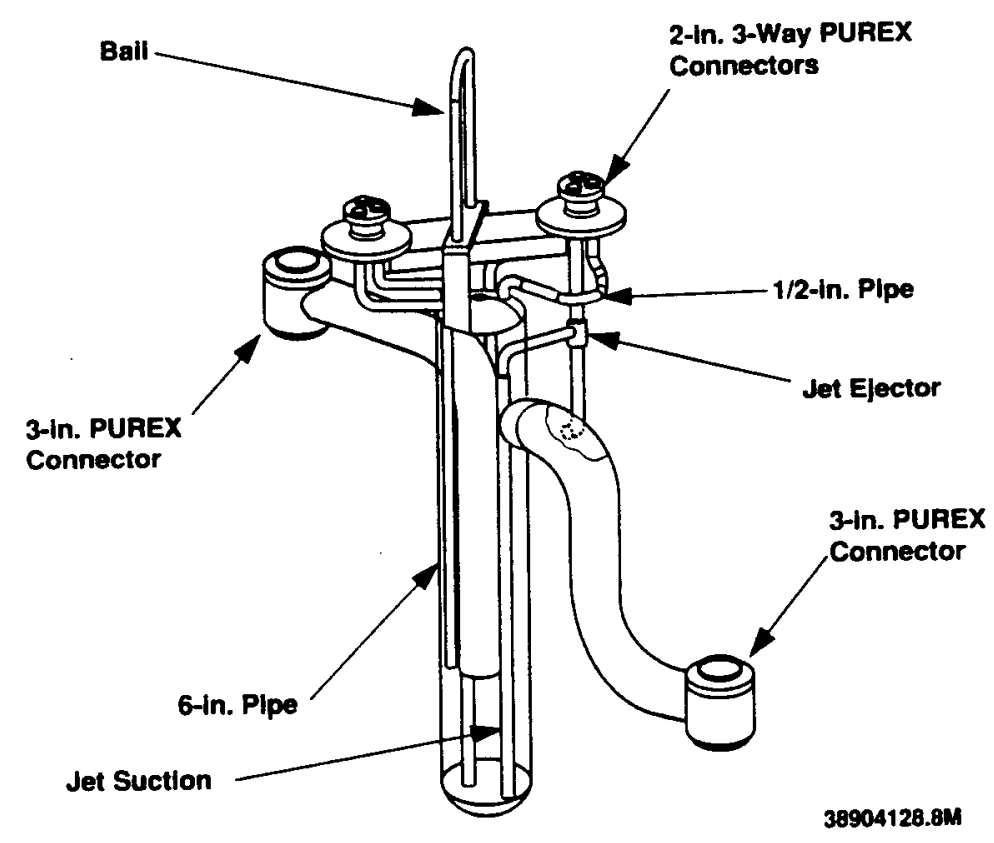

FIGURE 1.17. Seal Pot

Should the concentrator overfill, the solution will flow out through the seal pot and into the waste header. The feed hold tank, on the other hand, will overflow out the lowest nozzle with the least restriction because the seal pot connects to a nozzle on top of the tank. Both seal pots have a 20-in. differential built in. The seal pots have two 2 -in. three-way jumpers connecting to them which give them monitoring and corrective capabilities such as:

- weight factor (liquid level)

- specific gravity

- chemical addition (usualiy water)

- reference pressure

- jetting to the waste header. 


\subsubsection{Glass Pour Viewing}

The design criteria and two conceptual design sketches for glass pour viewing systems were completed and sent to WWNS for their review and selection of which concept to proceed with. The two concepts, the in-cell camera system and the periscope system, are shown in Figures 1.18 and 1.19.

\subsubsection{Infrared-Television Melter Viewing System}

The infrared-television (IR-TV) melter viewing system was procured, functionally tested at PNL, and delivered to WVNS during FY 1988. All milestones were completed for this activity as follows: 1) complete fabrication of the IR-TV melter viewing system; 2) ship the system to WVNS; and 3) issue a letter report describing the results of cold-testing the system at PNL.

Operational testing of the system in the slurry-fed ceramic melter (SFCM) at West Valley will be conducted during FY 1989 under the Remote Technology Review and Assistance subtask.

\subsubsection{Background}

The viewing system enables melter operations personnel to visually monitor the melt surface, in particular the cold cap. Cold-cap characteristics provide an important indicator for evaluating melter performance and controlling the melting process.

The viewing system developed for WVNS differs from previous PNLdeveloped systems in that the television camera is located in the hot-cell operating gallery. Previous systems have utilized a television camera mounted to an in-cell periscope assembly. Locating the camera outside the cel1 will extend camera 1 ife by protecting it from the hot cell's high gamma radiation environment. The WVNS viewing system comprises a wall plug assembly, a jumper (periscope) assembly, and a television camera as shown in Figure 1.20 .

During operations at the West Valley Site, the wall plug assembly (which is lead-filled to attenuate radiation from the hot cell) will be installed in a penetration of the vitrification cell wall. The periscope assembly will then be placed into the cell, and a flexible jumper, which supplies cooling air to the bottom lens, will be attached. The cooling air from this jumper 


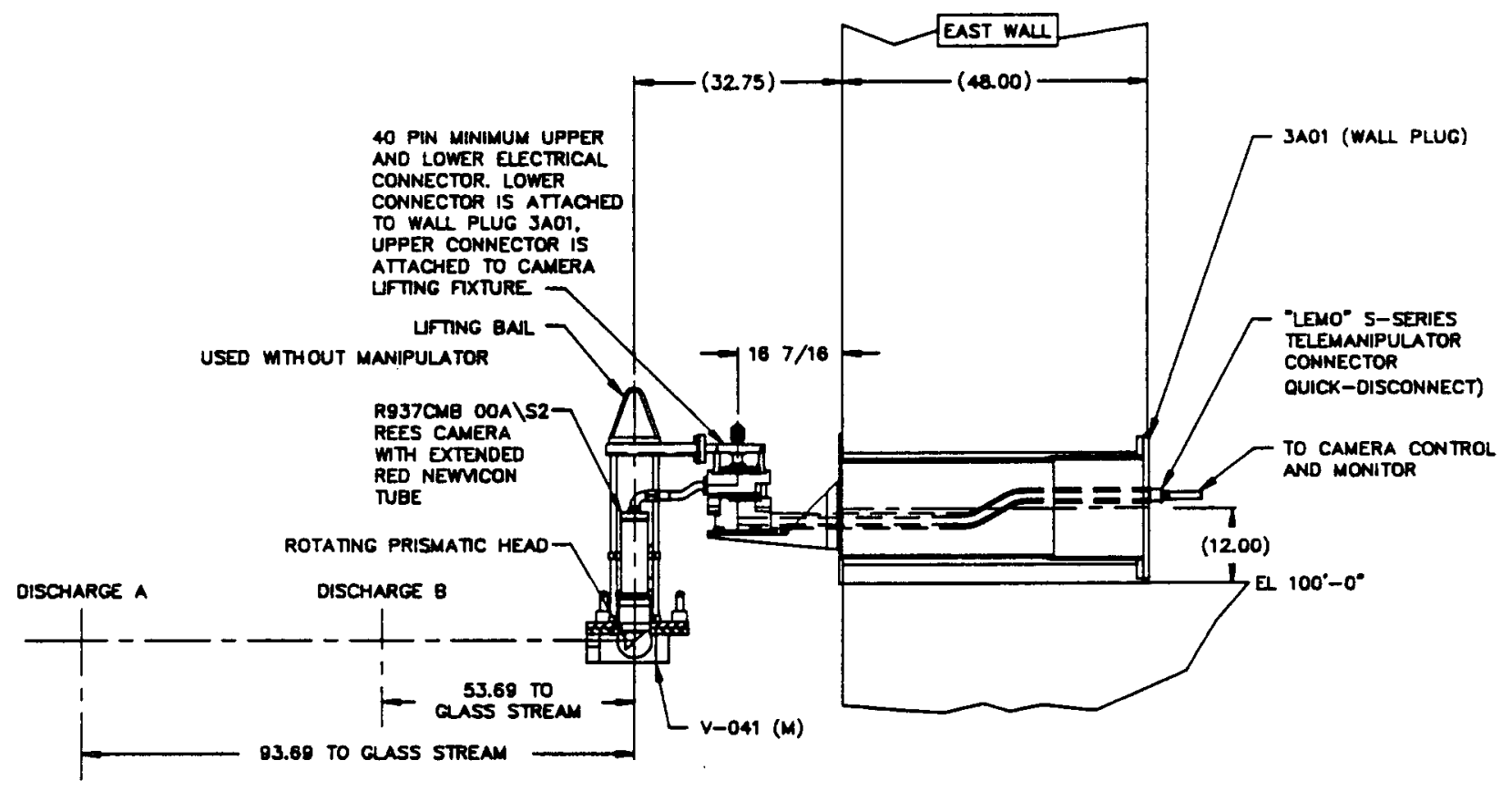

\section{FIGURE 1.18. Glass Pour Viewing In-Cell Camera System}

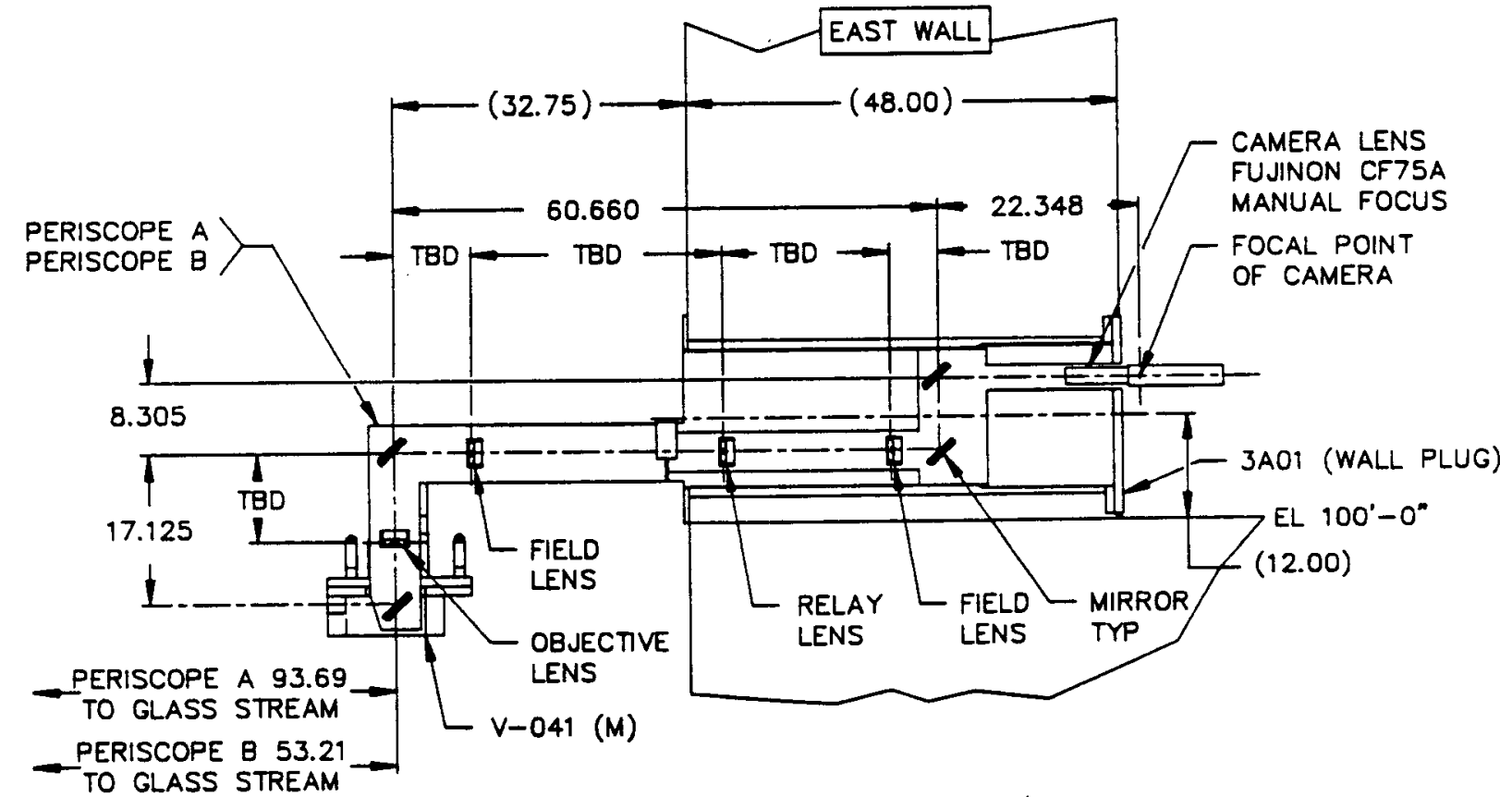

FIGURE 1.19. Glass Pour Viewing Periscope System 


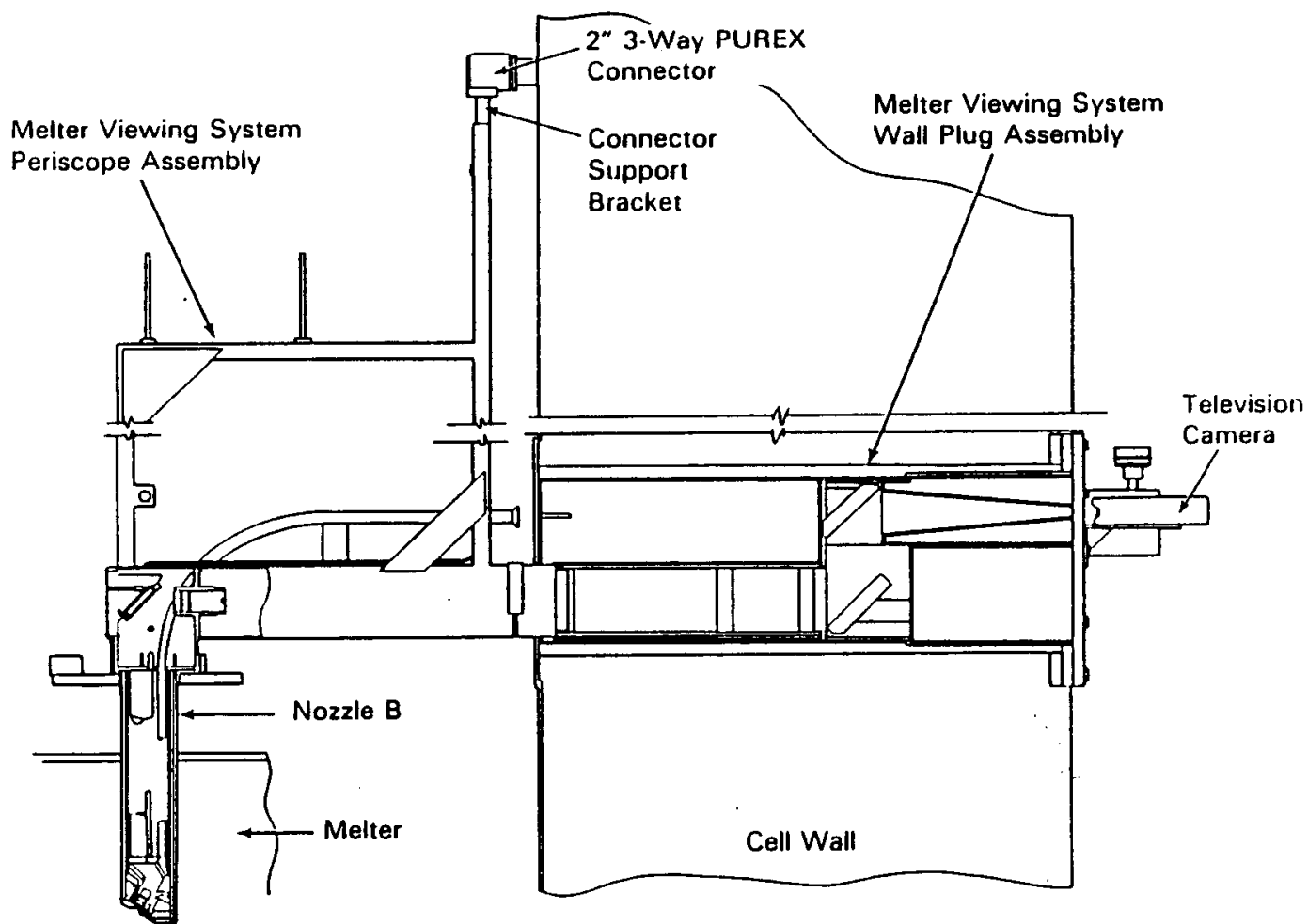

FIGURE 1.20. West Valley Nuclear Services Melter Viewing System

will flow at $-3 \mathrm{scfm}$ around the bottom lens and will exhaust into the melter. This air flow also protects the lens from feed or glass spatter and melter off gas. Once this air supply is started, the periscope assembly will be inserted into melter nozzle $B$. When seated in the melter nozzle, the periscope assembly horizontal leg will mate with the hot face end of the wall plug assembly. At the same time, a 2-in. three-way PUREX horizontal connector, attached to the periscope assembly dunnage, will mate with the wall nozzle. A second cooling air system is supplied from this connector. Air from this system flows at $20 \mathrm{scfm}$ around the lower lens housing and past the lower mirrors and exhausts into the cell. The PUREX nozzle also contains a steam line. Steam is used intermittently to remove any feed or glass spatter which may accumulate around the bottom lens viewing aperture. The air and steam systems are shown in Figure 1.21. 


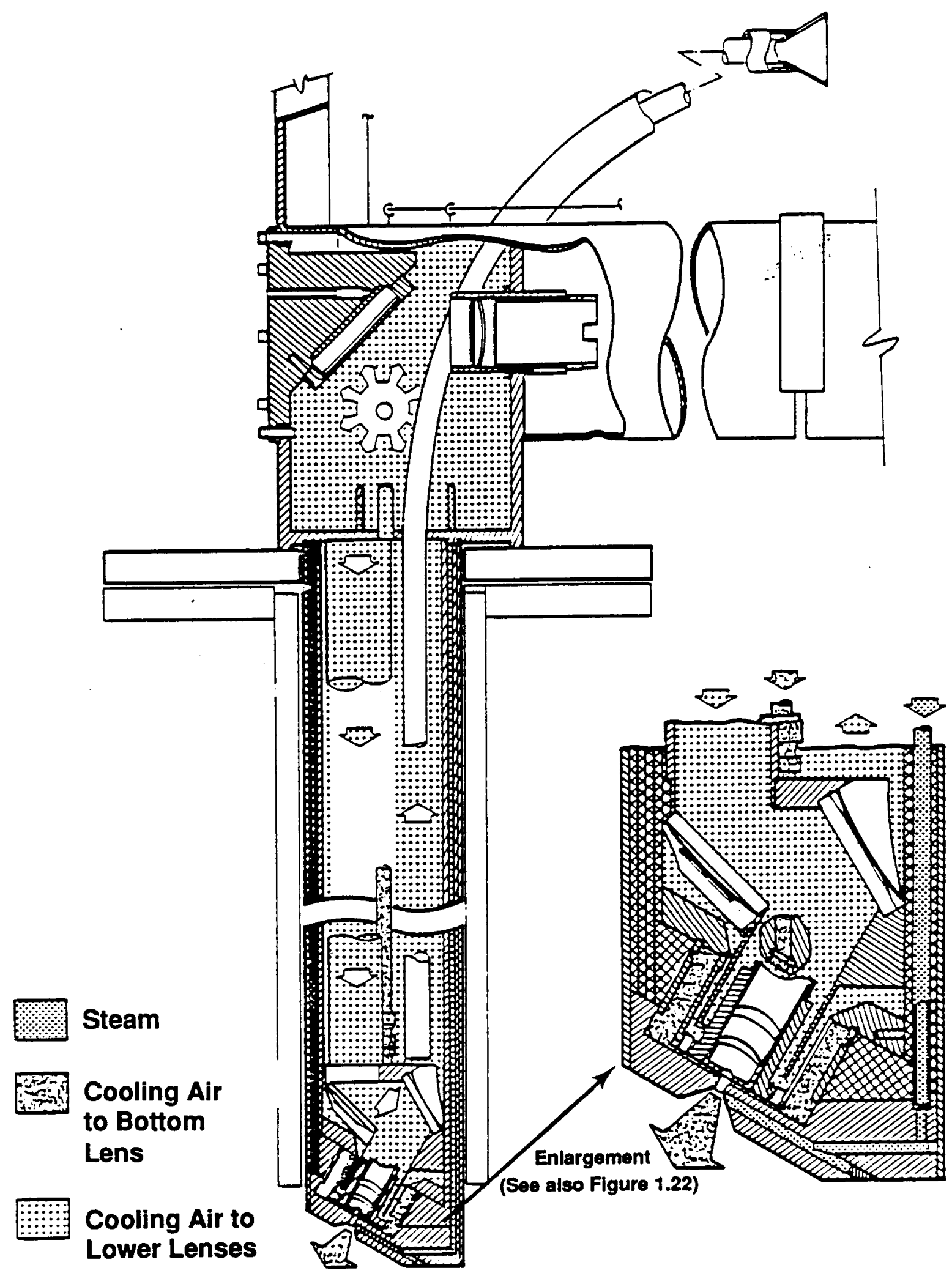

FIGURE 1.21. Air and Steam Systems for Melter Viewing System 
As shown in Figure 1.22, an image of the melt surface is transmitted, via a system of lenses and mirrors in each assembly, to a camera attached to the wall plug assembly cold face. The camera is equipped with a video tube chosen to have extended near-infrared response (optical radiation spectrum between 750 and $950 \mathrm{~nm}$ ) because the melt cavity sometimes lacks sufficient light to provide adequate images in the visual spectrum.

\subsubsection{Procurement}

Separate procurement orders were prepared for the wall plug and periscope assemblies. Requests for proposals were submitted to 15 different manufacturers across the U.S. for each item. A quality assurance survey was then conducted for each item before awarding the contracts to the low bidder, Basin Engineering Services, Inc., in Richland, Washington. The periscope and wall plug assemblies were received at PNL at the end of March 1988.

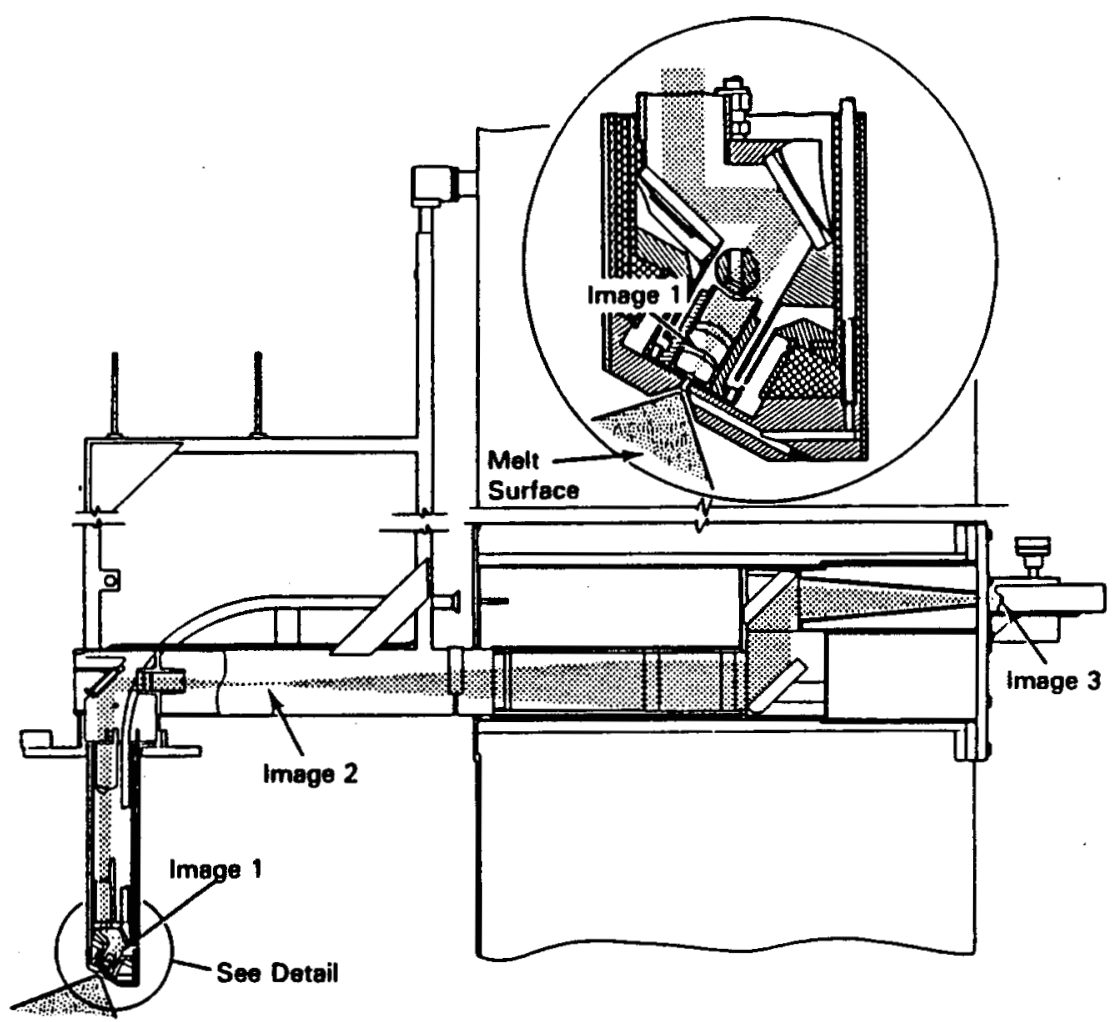

FIGURE 1.22. Optical Path of Melter Viewing System 


\subsubsection{Functional and Remote Installation Testing and Delivery}

Functional testing and remote installation testing were conducted using a mockup that had been designed and fabricated to the dimensional specifications of the vitrification cell north wall and melter nozzle B. The test system arrangement is depicted in Figures 1.23, 1.24, and 1.25.

Testing was completed in accordance with the approved WVNS Test Plan. Both functional and remote installation tests were performed with the following objectives.

- Functional testing:

- Verify alignment of a11 optical components.

- Determine the system's field of view.

- Determine the image resolution capability of each assembiy and of the integrated system.

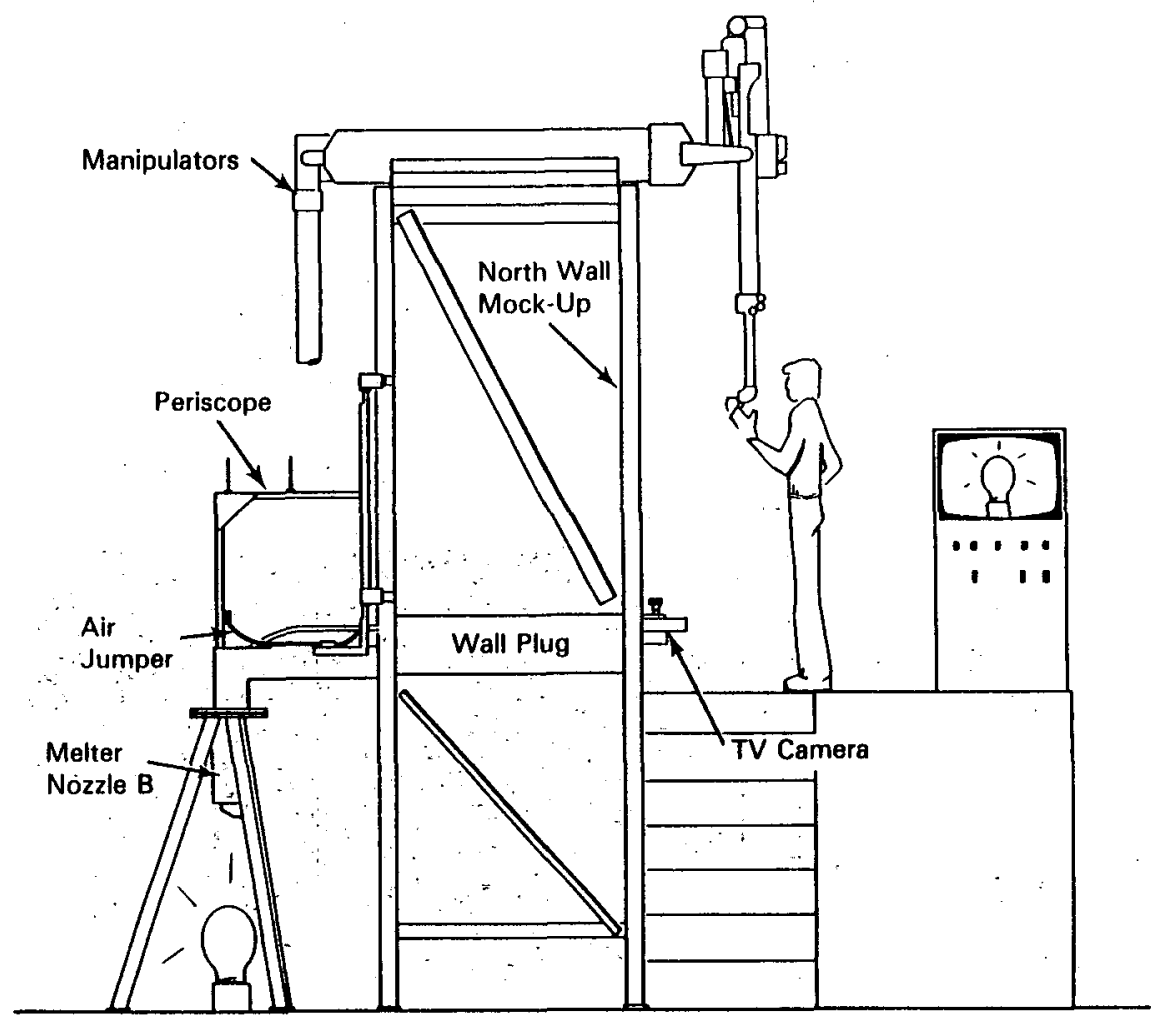

FIGURE 1.23. Test System Arrangement 


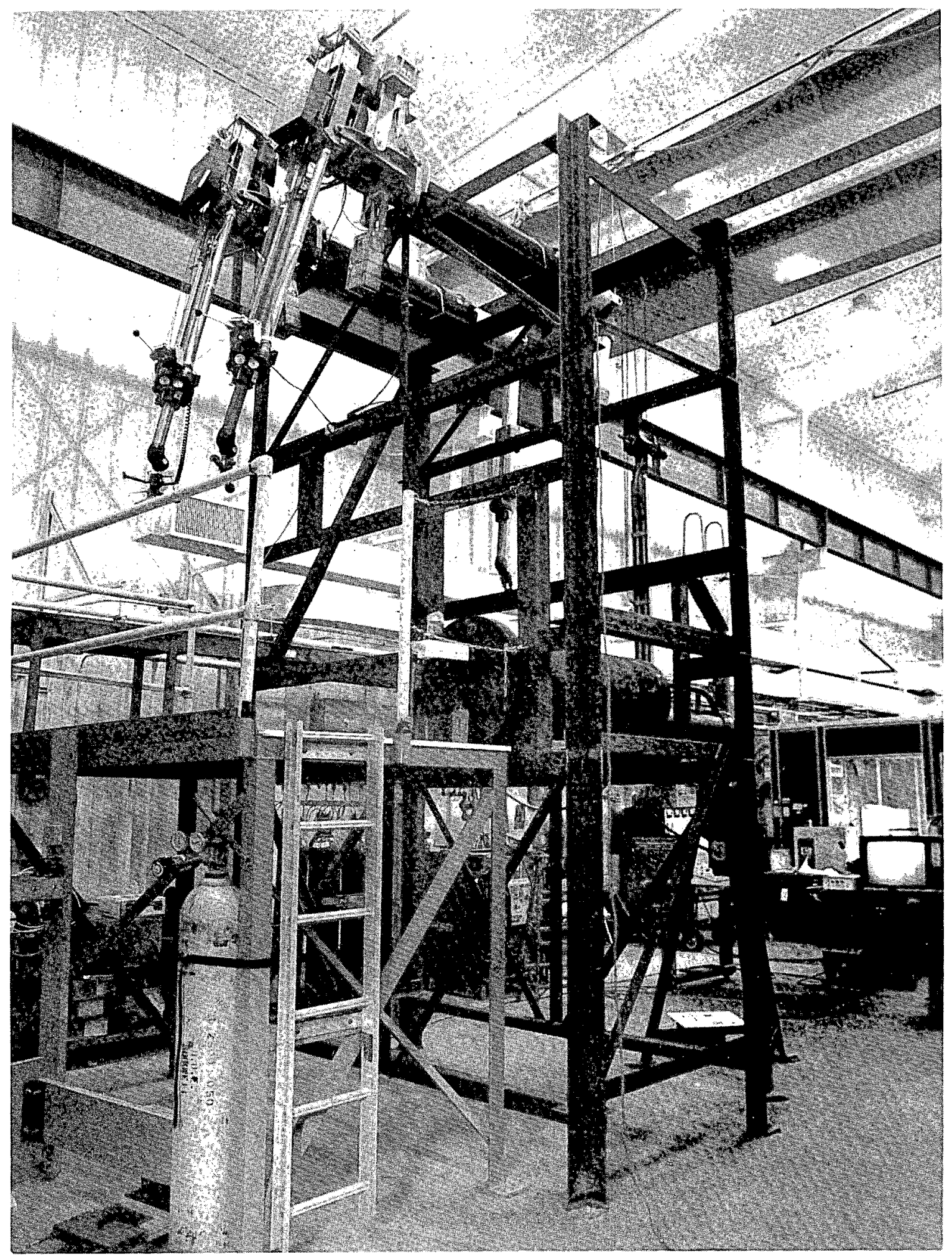

$8801728-19 c n$

FIGURE 1.24. Cold Face View of the Mockup Test Stand 


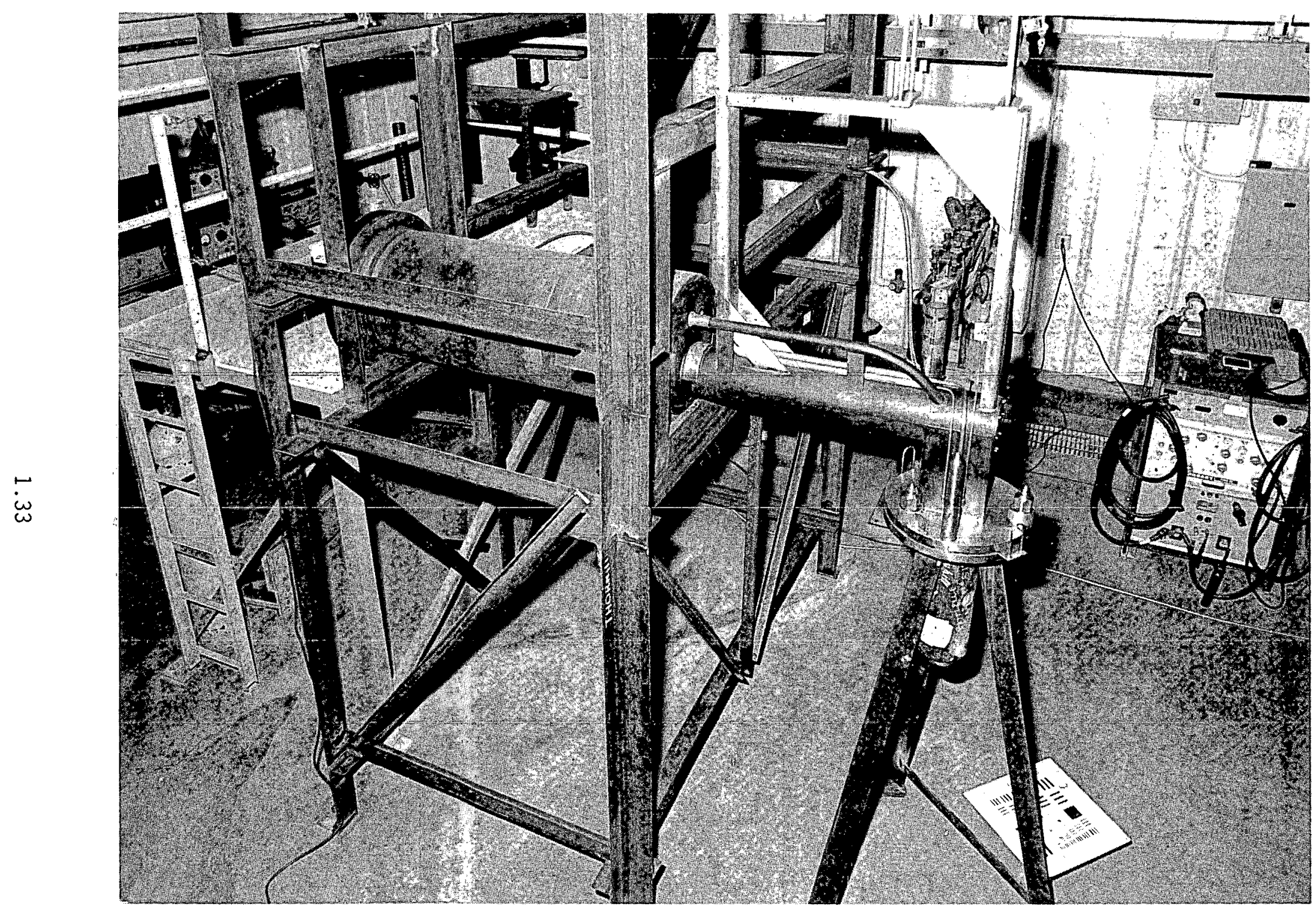

8801728-31cn

FIGURE 1.25. Hot Face View of the Mockup Test Stand 
- Remote installation testing:

- Place the periscope assembly into operating position in the melter.

- Demonstrate that the cooling air jumper for the bottom lens can be attached to the periscope's 1/2-in. Swagelok male connector using manipulators while the assembly is suspended from the crane.

- Verify that during insertion of the periscope assembly into the melter nozzle there is concurrent alignment/interface of the periscope's

- flange with the melter nozzle B flange

- horizontal leg with the wall plug assembly lens holder tube

- 2-in. three-way PUREX horizontal connector to wall nozzle 1360 .

Testing at melter temperature, radiation testing, and testing of the cooling air and steam systems were not part of the PNL functional testing activities. Flow through the steam and air lines was verified by a source inspection at the vendor's shop before the periscope assembly was received at PNL.

Individual shipping containers were designed and fabricated for both the wall plug assembly and the periscope assembly. The assemblies were packaged and shipped to the West Valley Site in mid-May in accordance with the approved technical procedures.

\subsubsection{Suction Canister System}

Conceptual drawings and engineering design criteria for the suction canister were issued to WVNS for review and comment in February 1988 as scheduled. The function of the suction canister system is to drain molten glass from the melter. The suction canister is intended to be used at the conclusion of radioactive operations to remove the glass that remains below the effective airlift height of the normal overflow drain system. The

(8) Swagelok is a registered trademark of Crawford Fitting Company, Solon, Ohio. 
suction canister will also be used to drain the melter in the event that both overflow systems fail.

In a melter failure, two suction canisters would be required. The capacity of a standard WVNS canister (at $85 \% \mathrm{fill}$ ) is about $26 \mathrm{ft}^{3}$. The potential melter capacity (assuming 4 in. of refractory corrosion over 3 years) is about $48 \mathrm{ft}^{3}$.

As currently conceived, the suction canister system (Figure 1.26) consists of a glass transfer jumper attached to a reference WVNS canister. The jumper is sealed at one end with an aluminum plug and is attached at the opposite end using a remotely removable split flange. A seal is located between the jumper flange and the canister flange to provide a vacuum-tight connection. The system is evacuated to a pressure of 1 torr before it is installed in the vitrification cell. In cell, the system is positioned to submerge the sealed end of the jumper through a melter nozzle into the molten glass. The aluminum plug melts and the molten glass is vacuum-transferred through the jumper into the suction canister. The jumper is then removed from the canister, and the canister proceeds through the remainder of the process without special handling.

To support the suction canister conceptual design it was also necessary to prepare thermal stress calculations on the reference WVNS glass canister design. The thermal stress analysis of the reference WVNS canister indicated that, under the conditions of vacuum and temperature summarized in the calculations, the bottom of the canister would fail without additional reinforcement. The calculations, however, are conservative, using worst-case temperatures; a detailed analysis on glass temperatures and flow rates should be conducted before final design of the suction canister system. Such detailed analysis was beyond the scope and funding level of this activity.

The suction canister could also be used for preventive melter maintenance to remove any noble metals/sludge that might accumulate on the melter bottom. The rheologies and densities of these materials, however, would need to be further investigated before the system's applicability for this use can be confirmed. 


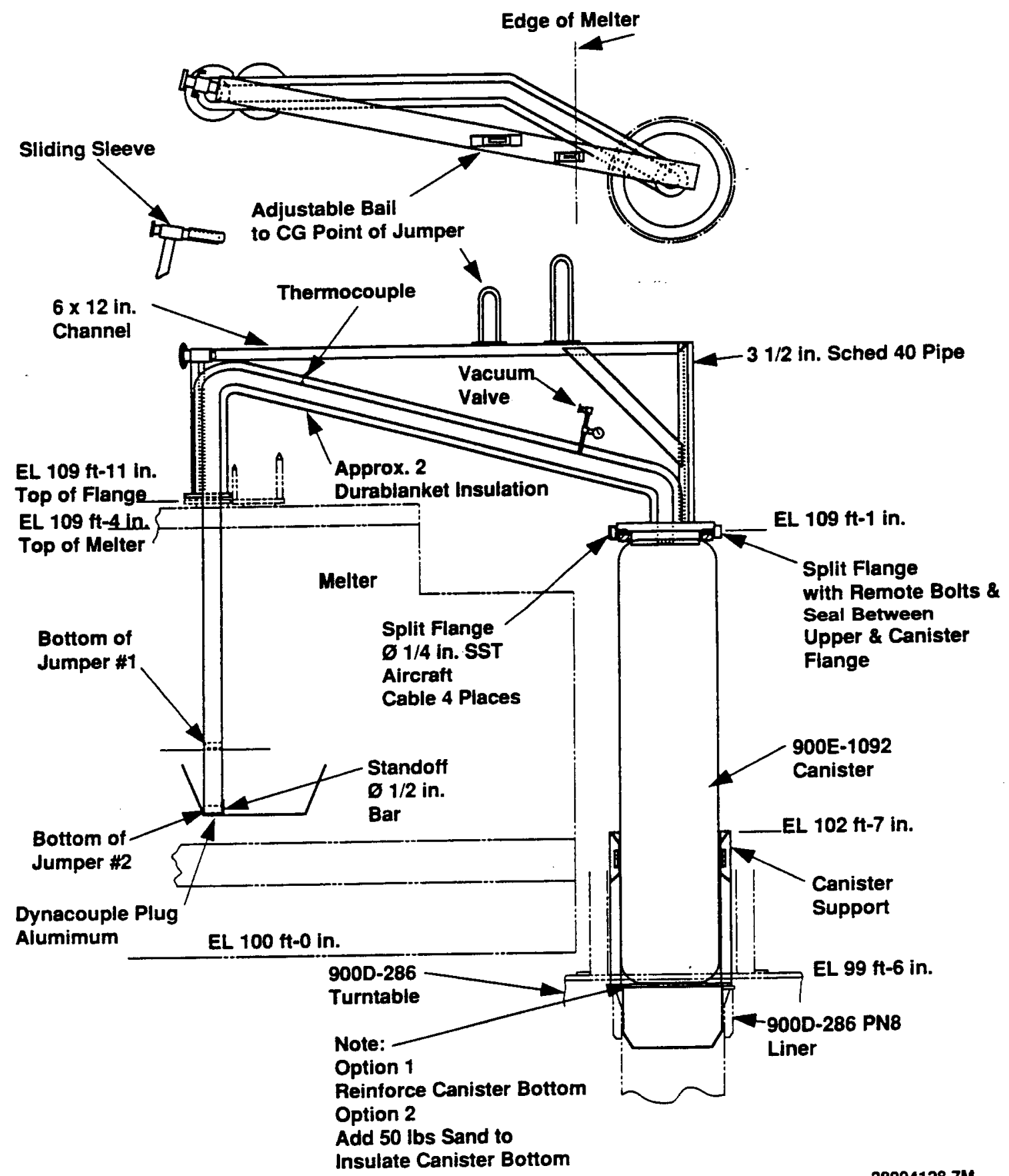

$38904128.7 M$

FIGURE 1.26. Suction Canister System 
1.4 PROCESS SUPPORT - W. A. Ross, S. 0. Bates, L. A. Bray, R. A. Brouns, C. C. Chapman, C. L. Fow, R. W. Goles, W. O. Heath, D. E. Kurath, R. K. Nakaoka, J. M. Perez, Jr., B. A. Pulsipher, J. H. Westsik, and K. D. Wiemers

The scope of work in this subtask comprises those activities associated with the equipment performance and process operations in the waste treatment system. The activities address needs related to the characterization of the wastes, process chemistry, waste mobilization, feed system, melter, off-gas treatment, and instrumentation and process control. Work in the task also related to work performed under the Remote Technology and Waste Form Qualification subtasks.

\subsubsection{Process Chemistry and Waste Characterization}

Samples of actual West Valley wastes and process fluids were received and characterized. They consisted of two samples of sludge from tank 8D-2, a dried sample of THOREX Waste from tank 8D-4, zeolite containing a partial loading of ${ }^{137} \mathrm{Cs}$, and typical utility water. These samples represent the major sources of chemicals that will comprise the waste streams. Two of the streams will result from the currently planned preprocessing of the waste in tank 8D-2. In this preprocessing, the supernatant will be removed and treated in ion exchange columns containing zeolite which will remove the radiocesium and allow the sodium to go on to the low-level waste treatment system. Following treatment of the supernatant in tank 8D-2, three tanks at West Valley will contain high-level waste. Tank 8D-1 will contain cesiumloaded zeolite, tank 8D-2 will contain PUREX alkaline sludge and residual supernatant, and tank 8D-4 wi11 contain THOREX acid waste. Current plans are to remove these tank contents and process them via an onsite vitrification facility, converting them to a borosilicate glass form.

Before these wastes can be vitrified, the following major operations must be performed:

1. Each process stream must be thoroughly analyzed to determine its chemical and radiochemical contents and its physical properties.

2. The alkaline supernatant must be removed from tank $8 D-2$ and processed through zeolite ion exchange to remove the ${ }^{137} \mathrm{Cs}$ content. 
3. The PUREX sludge must be washed with water to remove excess sodium sulfate to prevent adverse impact on vitrification.

4. To avoid the complication of processing three separate streams, the three wastes will be combined and blended in tank 8D-2.

5. The sludge/THOREX/zeolite combined waste will be transferred to a concentrator where excess water will be removed.

6. The waste will be blended with glass formers and adjusted with nitric acid to a final pH of about 4 .

The purpose of this study was to characterize West Valley tank 8D-2 sludge, tank 8D-4 THOREX acid waste, 137Cs-loaded zeolite, and WV utility process water, and to mix these materials as described above.

The following steps were completed:

- West Valley alkaline sludge $(57 \mathrm{~g})$, THOREX acid waste $(30 \mathrm{~mL})$, and cesium-loaded zeolite $(20 \mathrm{~g})$ were received in two shipments using the Battelle Columbus Laboratory shipping cask (BCL-3).

- Detailed chemical and radiochemical analyses were completed on the sludge, THOREX waste, zeolite, and WV utility water. Table 1.2 provides the detailed analytical results for the two sludge samples.

- Five grams of sludge, remaining after completion of the analytical tests, were used to complete the washing studies. Five washes were required to reduce the sulfate level to less than $1 \%$ of the initial value. Settling rate studies were completed for five wash steps. About 24 hours were sufficient to settle the sludge to a constant height.

- West Valley washed sludge, ground cesium-loaded zeolite (-140 mesh), THOREX acid waste neutralized with sodium hydroxide, and glass formers were mixed to achieve WV vitrification feed of near ATM-10(a) composition. The resulting composition was adjusted to a $\mathrm{pH}$ of $\sim 4$ and dried. About $16 \mathrm{~g}$ oxide weight were provided to the Materials Characterization Center to complete fabrication of a glass sample containing the actual wastes to be used in characterization tests.

The difficult tasks of sampling the underground tanks at WV and shipping small samples to PNL plus the major tasks of detailed chemical and

(a) ATM: Approved testing material. ATM-10 was the reference glass composition for the WVDP as defined by the Materials Characterization Center at PNL. 
IABLE 1.2 Summary of Analytical Results for Sludge Samples

Analyses Performed
Specific Gravity, g/md.
Percent Solids, wt\%
Total Carbon, wt\%
Anions (IC), $\mu \mathrm{g} / \mathrm{g}$

Pu Isotopic, mass \%

U Isotopic, mass \%

Cs Isotopic, mass \%

$\mathrm{Hg}, \mu \mathrm{g} / \mathrm{g}$

$\mathrm{H}-3, \mathrm{mCi} / \mathrm{g}$

Total Beta, Ci/g

$\mathrm{Sr}-90, \mathrm{~d} / \mathrm{m} / \mathrm{g}$

Alpha (AEA), mCi/g
Raw Sludge,

\begin{tabular}{|c|c|}
\hline g wet & Sludge $E$ \\
\hline & 2.01 \\
\hline & 73.7 \\
\hline & $0.29 \pm 15 \%$ \\
\hline$F^{-}$ & 88 \\
\hline $\mathrm{Cl}^{-}$ & 634 \\
\hline $\mathrm{NO}_{2}^{-}$ & 70,983 \\
\hline $\mathrm{NO}_{3}^{\prime}$ & 75,633 \\
\hline $\mathrm{PO}_{4}^{=}$ & 2,054 \\
\hline $\mathrm{so}_{4} \overline{\bar{z}}$ & 10,530 \\
\hline $\mathrm{Pu}-238$ & 1.21 \\
\hline .239 & 79.4 \\
\hline .240 & 15.8 \\
\hline-241 & 2.50 \\
\hline-242 & 1.06 \\
\hline-242 & 1.06 \\
\hline$U-238$ & 98.1 \\
\hline-236 & 0.176 \\
\hline-235 & 1.69 \\
\hline-234 & 0.024 \\
\hline Cs-137 & 30.4 \\
\hline-135 & 20.7 \\
\hline Cs- 134 & 0.0023 \\
\hline-133 & 49.0 \\
\hline
\end{tabular}

$7.7 \pm 1.2$

$2.42 E 6 \pm 10 \%$

$0.080 \pm 10 \%$

$6.47 \mathrm{E} 1 \mathrm{C} \pm 3.5 \%$

$1.40 \mathrm{E}-4 \pm 11 \%$

$1.28 \mathrm{E}-\overline{\mathrm{c}} \pm 3 \%$

$2.70 E-3 \pm 3 \%$

$0.338 \pm 3 \%$

$0.126 \pm 3 \%$

$3.62 \mathrm{E}-3 \pm 3 \%$

\begin{tabular}{l} 
Sludge F \\
\hline 2.07 \\
75.1 \\
$0.58 \pm 15 \%$ \\
112 \\
570 \\
68,483 \\
79,500 \\
2,160 \\
22,723 \\
1.19 \\
79.6 \\
15.7 \\
2.46 \\
1.09 \\
1.09 \\
98.1 \\
0.176 \\
1.73 \\
0.019 \\
30.1 \\
20.6 \\
0.0029 \\
49.2
\end{tabular}

$9.8 \pm 2$ $2.40 \mathrm{E}-6 \pm 10 \%$ $0.063 \pm 10 \%$ $7.61 E 10 \pm 3.7 \%$ $1.24 E-4 \pm 14 \%$ $1.23 E-2 \pm 3 \%$ $2.40 E-3 \pm 3 \%$ $0.2997 \pm 3 \%$ $0.1097 \pm 3 \%$ $3.10 E-3 \pm 3 \%$ 


\section{TABLE 1.2 (contd)}

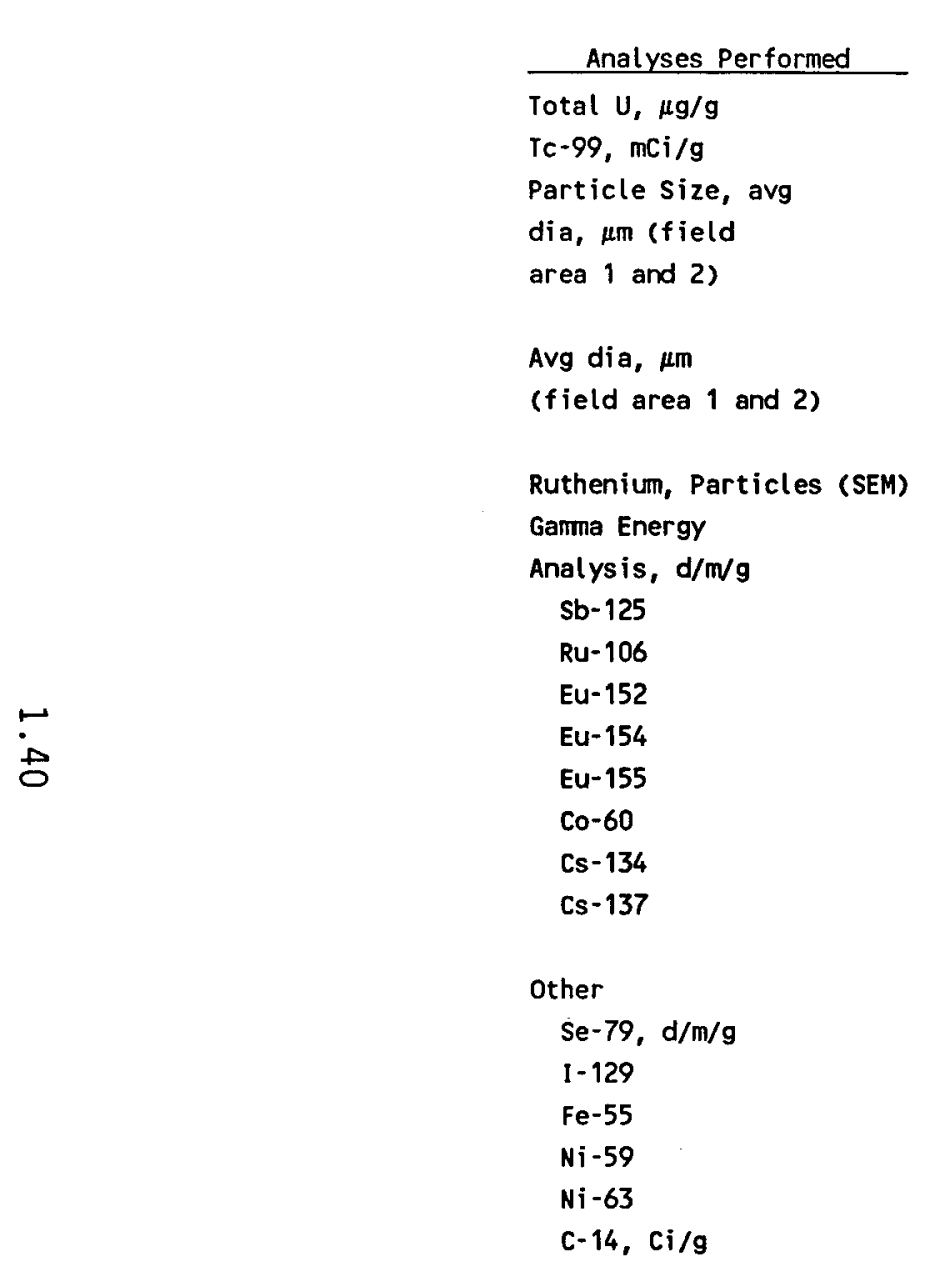

Raw sludge, $\mathrm{g}$ wet

\section{$d / m / g$}

$d / m / g$

$\mathrm{d} / \mathrm{m} / \mathrm{g}$
Sludge $E$

$3496 \pm 3.2 \%$

$3.99 E-4 \pm 2.4 \%$

$0.58 \pm 0.44$

$0.63 \pm 0.06$

$<0.3$ wt\%

$4.13 E 7 \pm 4 \%$

$2.90 \mathrm{E} 7 \pm 8.5 \%$

$7.48 \mathrm{E} 6 \pm 14 \%$

$1.15 \mathrm{Eg} \pm 3.5 \%$

$1.79 E 8 \pm 4 \%$

$5.34 E 7 \pm 22 \%$

$5.21 \mathrm{E} 6 \pm 3.5 \%$

$3.61 E 9 \pm 3.5 \%$

$845 \pm 13 \%$

$113 \pm 6.3 \%$

$3.00 E 6 \pm 7 \%$

$1.25 \mathrm{E5} \pm 2.5 \%$

$2.95 E 7 \pm 7 \%$

$1.98 \mathrm{E}-9 \pm 15 \%$
Sludge $F$

$6444 \pm 4 \%$

$3.18 \mathrm{E}-4 \pm 2.7 \%$

$0.59 \pm 0.44$

$0.51 \pm 0.37$

$<0.3$ wt\%

$5.53 \mathrm{E} 7 \pm 4 \%$

$1.54 \mathrm{E} 7 \pm 11 \%$

$6.05 \mathrm{E} 6 \pm 17 \%$

$9.97 \mathrm{E} 8 \pm 4 \%$

$1.52 E 8 \pm 4 \%$

4.72E7 \pm 23

$6.27 E 6 \pm 3.5 \%$

$2.94 \mathrm{E} 9 \pm 3.5 \%$
$500 \pm 66 \%$

$179 \pm 4 \%$

$2.45 \mathrm{E} 6 \pm 1 \%$

$8.44 E 4 \pm 2.5 \%$

$2.38 E 7 \pm 5.4 \%$

$4.06 \mathrm{E}-9 \pm 15 \%$ 


\section{IABLE 1.2 (contd)}

ICP Analytical Results

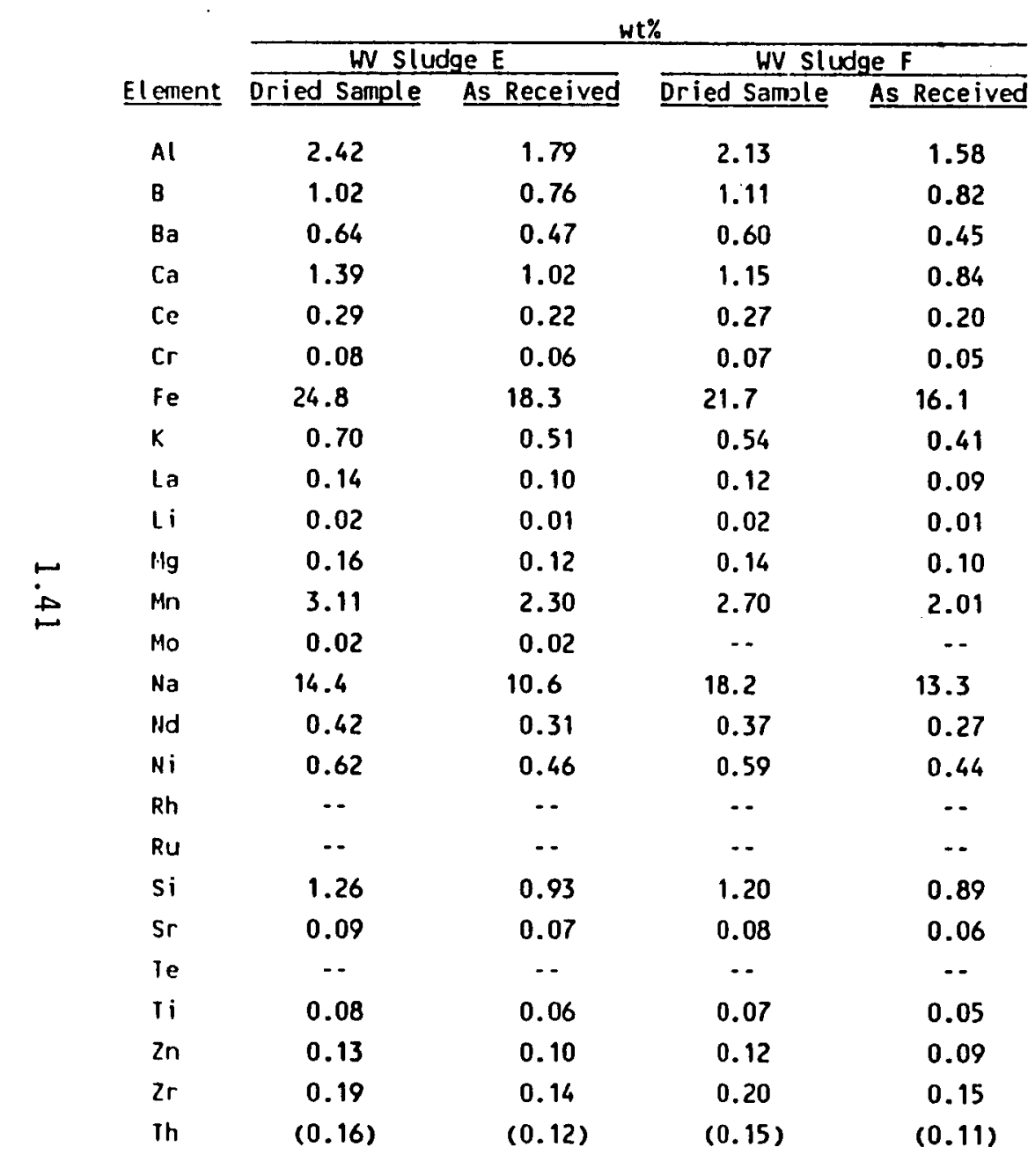

\begin{tabular}{|c|c|c|c|c|}
\hline \multirow[b]{3}{*}{ Oxide } & \multicolumn{4}{|c|}{ wt\% } \\
\hline & \multicolumn{2}{|c|}{ WV Sludge E } & \multicolumn{2}{|c|}{ WV sludge $F$} \\
\hline & Dried Sample & As Received & Dried Sample & As Received \\
\hline $\mathrm{Al}_{2} \mathrm{O}_{3}$ & 4.57 & 3.38 & 4.02 & 2.98 \\
\hline $\mathrm{B}_{2} \mathrm{O}_{3}$ & 3.30 & 2.44 & 3.57 & 2.84 \\
\hline Bao & 0.71 & 0.52 & 0.67 & 0.50 \\
\hline $\mathrm{CaO}$ & 1.94 & 1.43 & 1.61 & 1.17 \\
\hline $\mathrm{CeO}_{2}$ & 0.36 & 0.26 & 0.34 & 0.25 \\
\hline $\mathrm{Cr}_{2} \mathrm{O}_{3}$ & 0.11 & 0.08 & 0.10 & 0.07 \\
\hline $\mathrm{Fe}_{2} \mathrm{O}_{3}$ & 35.5 & 26.2 & 31.0 & 23.0 \\
\hline $\mathrm{K}_{2} \mathrm{O}$ & 0.84 & 0.62 & 0.66 & 0.49 \\
\hline $\mathrm{La}_{2} \mathrm{O}_{3}$ & 0.16 & 0.12 & 0.14 & 0.10 \\
\hline $\mathrm{Li}_{2} \mathrm{O}$ & 0.04 & 0.03 & 0.03 & 0.02 \\
\hline $\mathrm{MgO}$ & 0.26 & 0.19 & 0.23 & 0.17 \\
\hline $\mathrm{MnO}_{2}$ & 4.92 & 3.53 & 4.27 & 3.17 \\
\hline $\mathrm{MoO}_{3}$ & 0.04 & 0.03 & -. & 0.02 \\
\hline $\mathrm{Na}_{2} \mathrm{O}$ & 19.4 & 10.4 & 24.6 & 17.9 \\
\hline $\mathrm{Nd}_{2} \mathrm{O}_{3}$ & 0.49 & 0.36 & 0.43 & 0.32 \\
\hline NiO & 0.80 & 0.59 & 0.75 & 0.56 \\
\hline $\mathrm{RhO}_{2}$ & -. & -. & -. & -. \\
\hline $\mathrm{RuO}_{2}$ & -. & -. & - & -- \\
\hline $\mathrm{SiO}_{2}$ & 2.69 & 1.98 & 2.57 & 1.90 \\
\hline Sro & 0.10 & 0.08 & 0.09 & 0.07 \\
\hline $\mathrm{IeO}_{2}$ & -. & - & -. & -. \\
\hline $\mathrm{IiO}_{2}$ & 0.13 & 0.09 & 0.12 & 0.09 \\
\hline $2 n o$ & 0.17 & 0.12 & 0.15 & 0.11 \\
\hline $2 \mathrm{rO}_{2}$ & 0.26 & 0.19 & 0.27 & 0.20 \\
\hline $\mathrm{ThO}_{2}$ & $(0.18)$ & $(0.13)$ & $(0.16)$ & $(0.12)$ \\
\hline
\end{tabular}


radiochemical analyses have been challenging and rewarding. A11 major objectives were met except that the limited quantity of sludge did not permit the rheological analysis that was recommended.

\subsubsection{WVNS Proposed Supernatant Treatment System Operational Sequence}

WVNS was preparing to start up a supernatant treatment system (STS) for decontaminating the alkaline supernatant stored in tank 8D-2. The STS uses a zeolite ion-exchange process to remove most of the radioactive cesium before solidifying the supernatant as a concrete waste form. The original design basis for the STS was provided by PNL (Holton et al. 1984). Several operational modifications to the original process have been proposed by WVNS because budget constraints preclude continuous operation of the STS. At the request of WVNS, PNL completed a review of the WVNS proposed STS operational sequence.

The main areas reviewed were the existing data, zeolite (IE-96) requirements, loading of the first and second columns, column shutdown, and heat effects and gas generation by radiolys is in the second column during a 9 to 21-day standby period and during column restart. Additional laboratory work was also completed as needed to provide additional data. These included the determination of cesium distribution coefficients for the zeolite (IE-96) as a function of temperature and supernatant dilution, ion exchange column loading, column flushing and water recycle through the second, third, and fourth columns during a 9 to 21-day standby period.

The WVNS proposed mode of operation included several significant changes that affected primarily the operation of the ion exchange columns. These changes include operating the ion exchange columns intermittently and at a higher flow rate with no dilution of supernatant rather than continuously at a lower flow rate and/or with supernatant dilution. The higher flow rate increases ${ }^{137} \mathrm{Cs}$ loading on the downstream columns, raising the heat and gas generation rates from radiolysis during standby of the partially loaded columns. These effects can be mitigated by cooling the columns with a water recycle during column standby. Operating the ion exchange columns with no 
supernatant dilution can significantly increase the zeolite requirement, and this can impact the vitrification process by changing the feed composition and increasing the glass produced.

Although the review indicates that satisfactory performance can be obtained operating intermittently, it is generally agreed that continuous operation of the ion exchange columns at a slower flow rate and/or with supernatant dilution is preferred. Continuous operation would minimize the standby periods that generate excess gas. However, even with a continuous mode of operation there would probably still be unplanned downtime, causing the same concerns about heat generation and radiolysis as a planned downtime. Dilution of the supernatant, as orginally planned, can significantly reduce the zeolite requirement from that of the currently proposed approach.

Based on the review of the existing data and the performance and analysis of several laboratory experiments, the following conclusions and recommendations were made:

- The new zeolite IE-96 that WVNS has purchased for processing the alkaline supernatant does not differ significantly from the old IE-96 previously tested at PNL and WVNS. However, the loading capacities of the new zeolite appear to be slightiy $(4 \%-7 \%)$ higher.

- The total zeolite requirement for the proposed STS operational sequence (no supernatant dilution, $6^{\circ} \mathrm{C}$ ) is estimated by PNL to be about $51,000 \mathrm{~kg}$ anhydrous weight, or about $64,000 \mathrm{~kg}$ as-received weight, not including a factor for process upsets. This estimate is significantly higher than the WVNS estimate derived from the proposed STS operational sequence. The difference derives from the use of different assumptions in estimating the zeolite requirements and not from the PNL recommendations for changes to the operational sequence.

- The ion exchange columns should be operated at $6^{\circ} \mathrm{C}$, as proposed, since higher temperatures increase the zeolite requirement.

- With a supernatant dilution of $1: 3$ (initial volume:total volume) at $6^{\circ} \mathrm{C}$, the zeolite requirement could be reduced to about $35,000 \mathrm{~kg}$ (anhydrous weight) or about $44,000 \mathrm{~kg}$ (as-received weight). Smaller dilutions will result in smaller but still significant reductions in the zeolite requirement.

- The system decontamination factor (DF) for the proposed operational sequence for cesium is conservatively estimated to be at least 1,000 and could very likely exceed 10,000 . 
- In determining the percent breakthrough for cesium during column operation, at least 30 min should be allowed between sampling time and analysis time. This allows for reestablishment of secular equilibrium between $137 \mathrm{~m} \mathrm{Ba}$ and ${ }^{137} \mathrm{Cs}$, and thus accurate determinations of 137 Cs content.

- Before each standby period, all four columns should be flushed in series with demineralized water until the sodium concentration in the effluent from column 4 is less that $1 \mathrm{~g} / \mathrm{L}$.

- The recommended water-flushing procedure involves adding demineralized water continuously to the feed tank with the minimum possible liquid heel (150 gal) while continuously withdrawing the resulting solution. With this procedure at least 3000 gal of demineralized flush water will be required. The solution in the columns at the end of flushing should be sampled and analyzed for sodium content.

- Allowing the partially loaded second column to sit idle for 9 to 21 days with no cooling will raise the temperature in the column significantly, perhaps to the boiling point.

- During standby, columns 2,3 and 4 should be maintained near $6{ }^{\circ} \mathrm{C}$ with recycled demineralized water to prevent their excessive temperature rise. The sodium level in the recycle water should be maintained at less than $1 \mathrm{~g} / \mathrm{L}$ to minimize cesium desorption and migration. The sodium content of the recycle water should be determined periodically to ensure that its level stays below $1 \mathrm{~g} / \mathrm{L}$. The $137 \mathrm{Cs}$ concentration in the effluent from the second column should also be determined. The laboratory experiment recycling demineralized water showed that sodium content of the recycle solution can be expected to rise during each standby. This may require periodic blowdown of the recycle solution to keep the sodium level below $1 \mathrm{~g} / \mathrm{L}$.

- The rate of hydrogen generation in tank $8 D-1$, when supernatant processing is complete and the tank contains $8 \mathrm{E}+6 \mathrm{Ci}$ of ${ }^{137} \mathrm{Cs}$, is estimated to be $3100 \mathrm{~L} /$ day (STP). To keep the $\mathrm{H}_{2}$ below a limit of 2 v01\% will require an air purge rate of $3.8 \mathrm{scfm}$.

- Continuous operation of the ion exchange columns at a slower flow rate will minimize the concerns about heat and gas generation during standby.

\subsubsection{Vitrification System Test Plan}

A testing needs $p l a n$ was prepared in FY 1988 that identifies remaining requirements to aid in testing of the WVDP vitrification system. This system is by far the most complex and visible waste processing activity that the 
WVDP will undertake. The plan addresses formal requirements concerning safety, operations, and waste form qualification (WFQ).

A systematic testing strategy was developed to identify key independent variables for assessing their influence on achievement and for quantifying process control limits. Seventy-six independent testing needs were identified based on reviews of the Waste Acceptance Preliminary Specifications (WAPS) and on plant operational and process safety requirements and are shown in Table 1.3. Table 1.3 also suggests a test matrix in which the testing needs are logically integrated into the planned WVNS vitrification process test program known as FACTS (functional and checkout testing of system). Completion of these needs is considered necessary to provide efficient and successful operation of the vitrification facility. Failure to resolve issues during the current testing phase may lead to future delays in startup and hot operations and to increased total Project costs.

It was estimated that 50 man-years of qualified engineering staff above the current operational crews will be required to support the testing efforts and that an additional effort of about 30 man-years will be necessary for operational readiness activities. The current schedule of activities (Table 1.4) shows that most of the testing activities are concentrated in FY 1989, with some follow-up activities in FY 1990 and final confirmation testing in FY 1992. Because of the magnitude and complexity of the testing program that must be implemented, statistical tools, engineering analysis, and other numerical analysis techniques are proposed to minimize the testing days in the CTS. The plan also attempted to rank testing requirements so that those issues likely to be most critical to startup approval and efficient operation are addressed first.

The most challenging and important testing needs are those most likely to impact WVDP's schedule and total cost adversely. These testing needs are the development and demonstration of the required integrated process and chemistry controls and procedures to consistently do the following:

- produce an acceptable product (WAPS 1.1 .2 and 1.3.2)

- control reboil and foaming through bulk glass redox control 
TABLE 1.3. Correlation of Testing Objectives and Testing Methods

\section{Description - Title}

WVNS Waste Characterization

Waste and Feed Simulation

Slurry Tank Minimum Mix Time

CFMT, MFT, and Cold-Chemical Slurry Homogeneity

Evaluation of Hydragard Sampl ing Performance

volume Measurement

RECIPE Code Confirmation

Chemical Analyses

Chemical Additions

CFMT Evaporation

Caking and Precipitation in Tanks

Process Monitoring and Control

Idling Melter Mixing Test

- Melter Mixing

\& Volatilization from Glass Pour Stream

Glass Sampling

Volatilization and Entraiment to Off-Gas

Corrosion Products

Characterize Melter sludge

Radionucl ide Release Properties

Glass Product Crystallinity and Canister cooling

$G$ lass Transition Temperature and $T-T-T$ Response

Canistered Waste Form Storage and Shipment

Closure Weld Development and Qual ification

Temporary Canister Closure System

Canister Labeling

Radiogenic Gases

Free volume

Canister Decontamination

Chemical Compatibility

Canister weight
Engineering Pilot-Scale Component

Analysis Testing Testing

FACTS RunS

Support Operational SF-10 SF-10A SF-10B SF-10C Frit SF-11 SF-12 Testing

Testing

$\begin{array}{ccc}x & x & x \\ x & x & x \\ x & & x \\ x & & x \\ x & & x \\ x & & \end{array}$

$x$
$x$
$x$
$x$

$x$ $x$

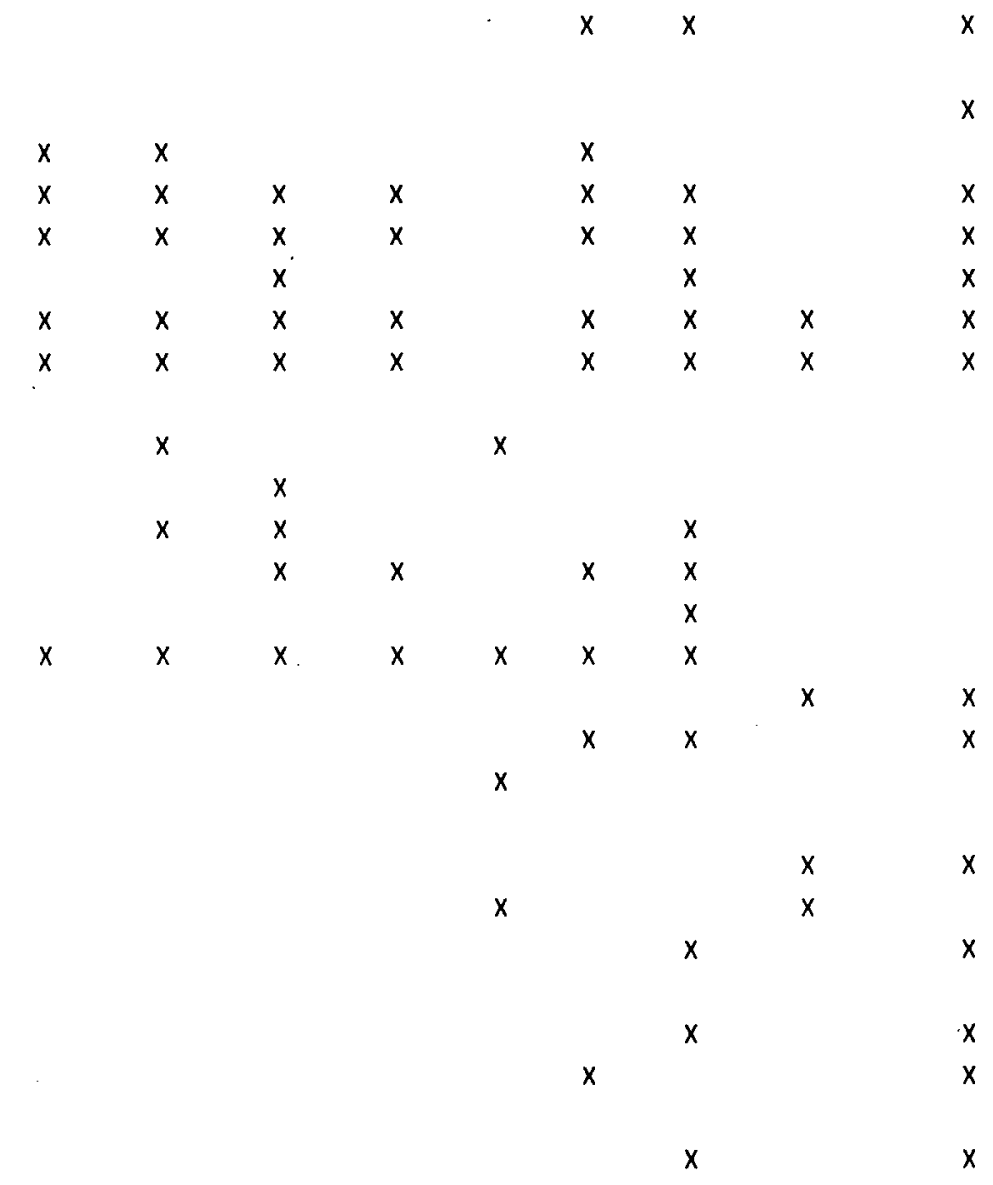


TABLE 1.3. (contd)

Engineering Pilot-Scale Component

FACTS Runs

Support Operational

Canister Handling Features

Demonstration of Rework of an Unacceptable Canister

Tank 8D-1 Corrosion

Waste Mobilization and Retrieval in Tank 8D-2

Define Heat Transfer Operating Parameters for CFMT

Demonstrate Agitator Restart

Characterize the CFMT Demister Performance

Demonstrate Cold Chemical Makeup Operation

Characterize Jet Transfer Operation and Control

Demonstration of CFMT/MFT Operations

Testing of CFMT and MFT Instrumentation

- Specify Operating Parameters of SFCM Feed System

Grinder Wear Calibration

Discharge of Sulfur from Vitrification Process

Effect of Melter Feed Components on SFCM Process Char.

Effect of Waste Variability on SFCM Bulk Glass Redox State

Define Film Cooler Flow Rate Limits

Establ ish Minimum SFCM Plenum Vacuum Requirements

Design and Operating Requirements for the Glass Level Bubbler

In-Situ Determination of Melter Sludge Layer Depth

Establ ish SFCM Mixing Char. and Opt imum Electrode Power skewing Assess Suction Canister

Develop On-Line Process Rate Measurement

Interim Examinations of Refractory Condition

Overflow Heater Aging

Correlation of Air Cool ing with Electrode Temperature

Characterize Glass-Pouring Operation

Maximum Pumpdown of the Melting Chamber

Assess East Overflow Functionality

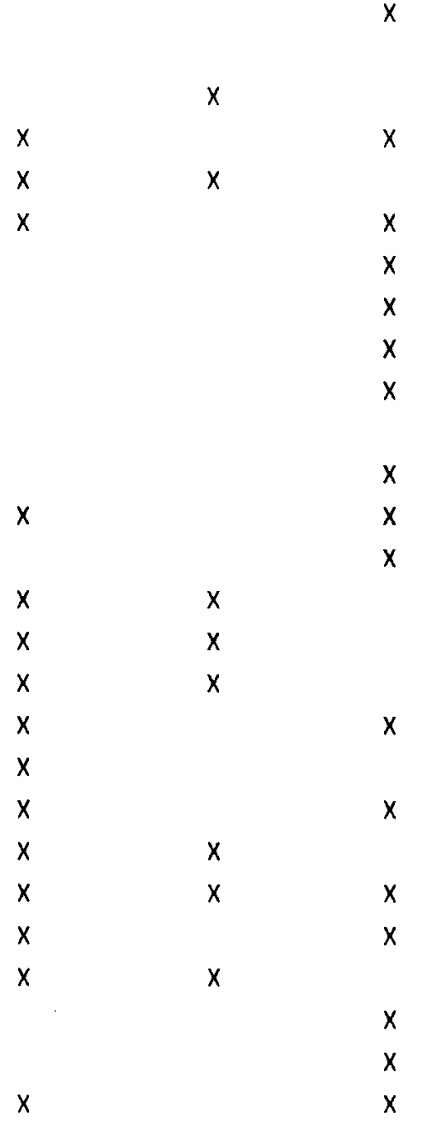

$x$

$x$

$x-x$

$x-x$

$x$

$x-x-x$

$x$

$x$

$x$

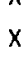

$\begin{array}{lll}x & x & x \\ x & x & x \\ x & & \end{array}$

$x$

$x$

$x$

$x$ 


\section{TABLE 1.3. (contd)}

Description - Title

Engineering Pilot-Scale Component Analysis

FACTS Runs

Support Operational

Mel ter Destructive Examination Plan and Study

$x$ Production Attainment Verification

Glass Level Detection System

off-Gas System Integrated Testing

Off-Gas Line Blockages

Off-Gas Sampling Techniques

Off-Gas Line Condensation

Submerged Bed Scrubber Pluggage

SBS Vessel Level Detection

HEME Backflush Cycle Definition

HEME Deterioration During Operation

Rate of Loading of Process HEPAS

off-Gas System Corrosion

$\mapsto$ Analytical Chemistry Capabilities $x$

$x$

$x$

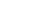

$x$
$x$
$x$
$x$

$x$
$x$
$x$
$x$

$$
\begin{aligned}
& x \\
& x
\end{aligned}
$$

$x$ SF-10A SF-10B SF-10C Frit SF-11 SF-12

Iesting

Testing

$\stackrel{\infty}{\infty}$ 
IABLE 1.4. Test Objectives, Priorities, Organizational Assignments, and Schedule

\section{Description of Test Objective}

WVNS Waste Characterization

Waste and Feed simulation

Slurry Tank Minimum Mix Time

CFMT, MFT, and cold-Chemical slurry Homogeneity

Evaluation of Hydragard Sampl ing Performance

Volume Measurement

RECIPE Code Confirmation

Chemical Analyses

Chemical Additions

CFMT Evaporation

Caking and Precipitation in Tanks

$\mapsto \quad$ Process Monitoring and Control

is Idling Melter Mixing Test

Melter Mixing

Volatilization from Glass Pour Stream

Glass Sampling

Volatilization and Entrairment to Off-Gas

Corrosion Products

Characterize Melter sludge

Radionuclide Release Properties

Glass Product Crystallinity and Canister cooling

Glass Transition Temperature and T-T-T Response

Canistered Waste Form Storage and Shipment

closure Weld Development and Qualification

Temporary Canister Closure System

Canister Labeling

Radiogenic Gases

Free Volume

Canister Decontamination

Chemical Compatibility

Canister Weight
Priorities

(Highest is 1)

PNL WNNS WNS PNL CUA(a) AU(b) $\mathrm{CPAC}^{(c)}$

\begin{tabular}{ccc} 
Activity Duration \\
\hline Pre FY88 FY88 FY89 FY90 FY91 FY92
\end{tabular}

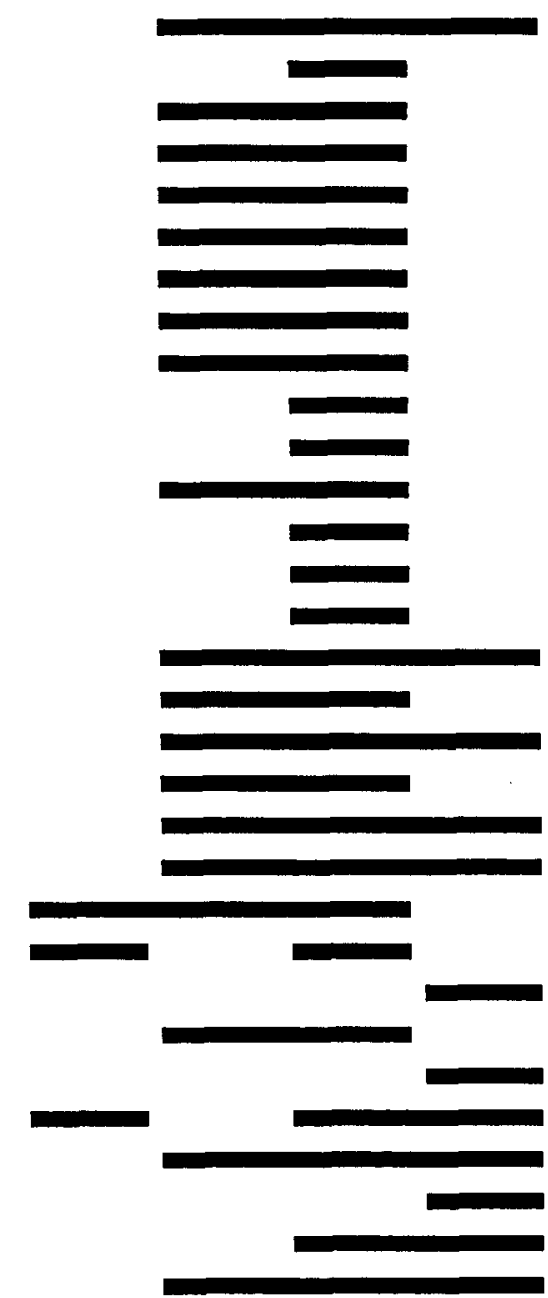

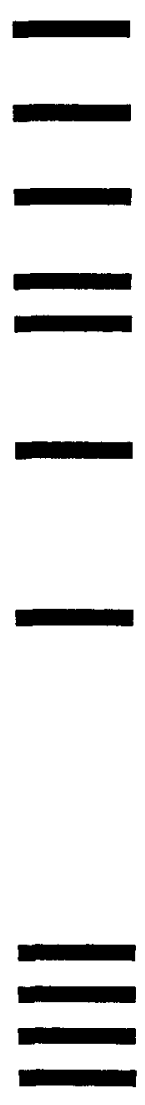


TABLE 1.4. (contd)

Description of Test Objective

Canister Dimensions

Canister Drop Tests

Canister Handling Features

Demonstration of Rework of an Unacceptable Canister

Tank 80-1 Corrosion

Haste Mobilization and Retrieval in Tank $80-2$

Define Heat Transfer Operating Parameters for CFMT

Demonstrate Agitator Restart

Characterize the CFMT Demister Performance

Demonstrate Cold Chemical Makeup Operation

Characterize Jet Transfer Operation and Control

$\mapsto \quad$ Demonstration of CFMT/MFT Operations

if Testing of CFMT and MFT Instrumentation

Specify Operating Parameters of SFCM Feed System

Grinder Wear Calibration

Discharge of Sulfur from Vitrification Process

Effect of Melter Feed Components on SFCM Process Char.

Effect of Waste Variability on SFCM Bulk Glass Redox State

Define Film Cooler Flow Rate Limits

Establish Minimum SFCM Plenum Vacuum Requirements

Design and Operating Requirements for the Glass Level Bubbler

In-Situ Determination of Melter Sludge Layer Depth

Establish SFCM Mixing Char. and Optimum Electrode Power skewing 2

Assess Suction Canister

Develop On-Line Process Rate Measurement

Interim Examinations of Refractory Condition

Overflow Heater Aging

Correlation of Air Cooling with Electrode Temperature

Characterize Glass-Pouring Operation

Maximum Pumpdown of the Melting Chamber

Assess East Overflow Functionality
Priorities

(Highest is 1)

Activity Assignment

WNS PNL CUA(a) AU(b) $\operatorname{CPAC}^{(c)}$

\begin{tabular}{ll} 
Activity Duration \\
\hline Pre FY88 FY88 FY89 FY90 FY91 FY92
\end{tabular}

$x$

$x$

$\mathrm{x}$

$x$
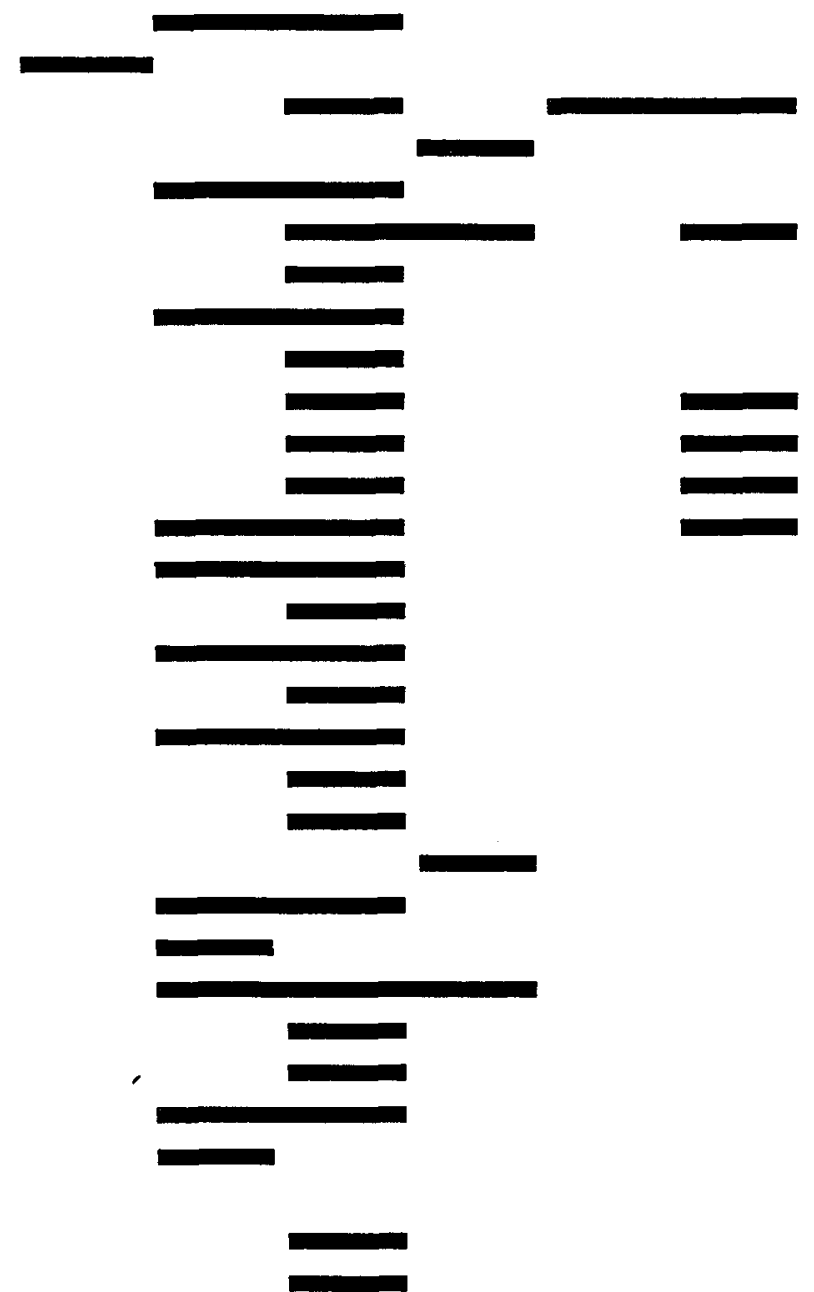


\section{TABLE 1.4. (contd)}

Priorities

Description of Test Objective

Melter Destructive Examination Plan and Study Production Attainment Verification

Glass Level Detection System

off-Gas System Integrated Testing

off-Gas Line Blockages

off-Gas Sampling Techniques

of $f-G$ as Line Condensation

submerged Bed Scrubber Pluggage

SBS Vessel Level Detection

HEME Backflush Cycle Definition

HEME Deterioration During Operation

$\mapsto \quad$ Rate of Loading of Process MEPAs

ir off-Gas System Corrosion

Analytical Chemistry Capabilities
(Highest is 1)

Activity Assigrment

PNL WNS WNNS PNL CUA(a) AU(b) $\mathrm{CPAC}^{(c)}$

$x$

$x$

$\mathrm{X}$

$x$

$x$

$\mathrm{x}$

$x$

$x$

$x$

$x$

$\mathbf{x}$

\begin{tabular}{ll}
\multicolumn{2}{c}{ Activity Duration } \\
\hline Pre FY88 FY88 & FY89 FY90 FY91 FY92
\end{tabular}

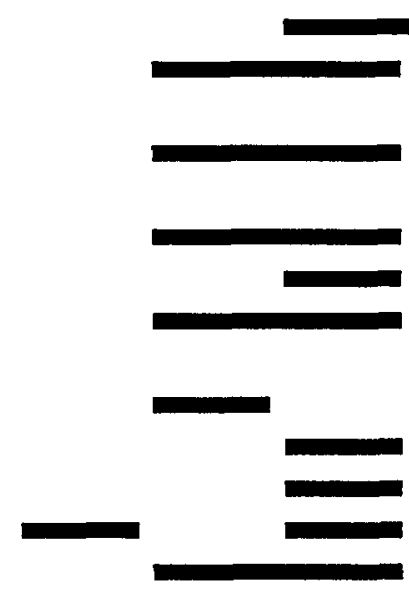

(a) Catholic University of America

(b) Alfred University

(c) Center for Process Analytical Chemistry, University of Washington 
- ensure that no significant secondary phases (crystals, molten salts, and/or conductive sludges) form which cause disruption or failure of the melter

- obtain the needed processing rate through the melter.

The following are specific conclusions and recommendations resulting from preparation of the plan:

- Adequate, early testing is most beneficial because it minimizes modifications and testing later during the more costly, mature stages of the project. Further, it provides a sound technical basis for obtaining approval to proceed with hot operations.

- Approval or concurrence with the Office of Civilian Radioactive Waste Management (OCRWM) and the Nuclear Regulatory Commission (NRC) on the technical and quality assurance plans for the qualification activities, down through implementation of procedures, should be obtained to avoid delays before startup. At a minimum, frequent and thorough communications with these institutions on the approach and results from functional and checkout testing of system (FACTS) should be maintained.

- The full range of evaluation methods--including laboratory- through full-scale testing, engineering analyses, and application of existing process simulation models--needs to be used to efficiently resolve remaining testing needs.

- An improved estimate of waste composition should be developed to increase the probability that the testing data are useful for hot operations and process/product qualification. Additional samples should be obtained and fully characterized.

- The analytical laboratory should complete WFQ work under the same hot-cell conditions anticipated for hot operations and should implement statistical control charting for all critical work.

- Based on the high dilution factor used to determine total dose to the surrounding population, characterization of the off-gas equipment's DF performance can be significantly reduced.

- Several process and equipment selections have not yet been made by WVDP. Their deferral may impede authorization from OCRWM and NRC to go to hot operations. Specifically, the canister welder and the final canister decontamination system are not yet selected. After these are selected, the WVDP testing program should be expanded to include them. 
- The WFQ simulation model computer code developed by the Nuclear Waste Treatment Program (NWTP) and the HWVP, or a similar code, should be used extensively to reduce full-scale testing for satisfying WFQ and process operations requirements.

- A technical data summary of the testing results in a simple, concise, trackable and useful document should be created, updated, and maintained.

- The necessary and sufficient documentation required for the process and for each canister for the radioactive production records should be defined and implemented during the FACTS testing program.

\subsubsection{Evaluation of Sources of Batch-to-Batch Variability in the West Valley Glass Composition}

Although sampling the wastes and adding individual bulk glass formers produces glass with a given target composition, normal uncertainties about process measurements, chemical analyses, and process control actions will usually prevent hitting the target exactly. The objective of this work was to investigate how much the true glass composition can be expected to vary because of these uncertainties and to identify which factors contribute most to the expected variation.

\subsubsection{Experimental Design}

Variability around the target composition is quantified by the batch-tobatch variation. A simulation model was used to track the true glass composition without introducing the sampling and analytical uncertainties that would occur in determining the glass composition in the real process. By comparing the batch-to-batch variations of the actual glass composition under varying conditions, the major factors can be identified that cause departures from the target composition.

Several factors could affect the variability of actual waste glass composition. Four major ones were identified and included in the study, as shown below:

- Variation in the waste stream composition entering the vitrification process. 
- Sampling and analytical uncertainty in determining the waste composition. The more uncertainty in the apparent composition, the greater will be the error in determining the recipe for the additions of glass-forming and shim chemicals.

- Uncertainty in tank volume determinations. If the volume of the tank contents is not well characterized, the amount of glass formers added may not be correct.

- Variation in cold chemical additions. The true amounts added may vary from the intended amounts.

A set of simulation runs was statistically designed to examine the individual and interactive effects of these four factors. It was set up as a screening study to examine only a high and low level for each factor. Because there were only four factors, each at two levels, a full-factorial design was feasible that resulted in sixteen $\left(2^{4}\right)$ runs of the process simulation. The high and low factor levels are shown in Table 1.5.

\subsubsection{Discussion of Results}

Batch-to-batch variability was found to decrease from the chemical feed makeup tank (CFMT) through the melter feed hold tank (MFT) to the melter as a result of the damping effect of the tank heels and the mixing behavior. If the four factors 1 isted in Table 1.5 were at their maximum assumed relative standard deviation (RSD) of $20 \%, 15 \%, 15 \%$, and $5 \%$, respectively, then the RSD

TABLE 1.5. Selected Factors and Levels for the Statistical Design of Simulation Runs

\begin{tabular}{|c|c|c|}
\hline Factor & High Level & Low Level \\
\hline $\begin{array}{l}\text { Waste Stream Composition Relative } \\
\text { Standard Deviation (WRSD) }\end{array}$ & $20 \%$ & $5 \%$ \\
\hline $\begin{array}{l}\text { Analytical and Sampling } \\
\text { Relative Standard Deviation } \\
\text { (RSDA and RSDS) and Number of } \\
\text { Samples (NS and NA) }\end{array}$ & $\begin{aligned} \text { RSDS } & =1 \% \\
\text { RSDA } & =15 \% \\
N S & =1 \\
N A & =1\end{aligned}$ & $\begin{aligned} \text { RSDS } & =1 \% \\
\text { RSDA } & =5 \% \\
N S & =1 \\
N A & =3\end{aligned}$ \\
\hline $\begin{array}{l}\text { Tank Volume Measurement Relative } \\
\text { Standard Deviation (VRSD) }\end{array}$ & $15 \%$ & $5 \%$ \\
\hline $\begin{array}{l}\text { Cold Chemical Addition Relative } \\
\text { Standard Deviation (BRSD) }\end{array}$ & $5 \%$ & $2 \%$ \\
\hline
\end{tabular}


for most glass components would be more than $10 \%$ in the CFMT, about $8 \%$ in the MFT, and about $5 \%$ in the glass (see Table 1.6). If the four factors were at their low values of $5 \%$ RSD except for a $2 \%$ batching error, then the RSD for the glass components in the glass would be less than $1 \%$.

TABLE 1.6. Batch-to-Batch Relative Standard Deviation Estimates for the Two Levels of Analytical and Sampling Uncertainty

\begin{tabular}{|c|c|c|c|c|c|}
\hline Element & $\begin{array}{r}\text { Factgr } \\
\text { Level(a) }\end{array}$ & $\begin{array}{l}\text { Target } \\
\text { Concen- } \\
\text { tration } \\
\end{array}$ & $\begin{array}{c}\text { CFMT } \\
\text { Relative } \\
\text { Std. Dev.(b) } \\
\end{array}$ & $\begin{array}{c}\text { MFT } \\
\text { Relative } \\
\text { Std. Dev. }\end{array}$ & $\begin{array}{l}\begin{array}{r}\text { Glass } \\
\text { Relative } \\
\text { Std. Dev. }\end{array} \\
\end{array}$ \\
\hline $\mathrm{SiO}_{2}$ & $\begin{array}{l}\text { High } \\
\text { Low }\end{array}$ & $\begin{array}{l}42.5 \\
42.5\end{array}$ & $\begin{array}{l}5.03 \% \\
1.64 \%\end{array}$ & $\begin{array}{l}3.83 \% \\
1.26 \%\end{array}$ & $\begin{array}{l}1.88 \% \\
0.78 \%\end{array}$ \\
\hline $\begin{array}{l}\text { Alkali } \\
\text { Oxides }\end{array}$ & $\begin{array}{l}\text { High } \\
\text { Low }\end{array}$ & $\begin{array}{l}16.3 \\
16.3\end{array}$ & $\begin{array}{l}9.51 \% \\
2.54 \%\end{array}$ & $\begin{array}{l}7.17 \% \\
1.93 \%\end{array}$ & $\begin{array}{l}3.59 \% \\
0.93 \%\end{array}$ \\
\hline $\mathrm{Fe}_{2} \mathrm{O}_{3}$ & $\begin{array}{l}\text { High } \\
\text { Low }\end{array}$ & $\begin{array}{l}12.0 \\
12.0\end{array}$ & $\begin{array}{r}11.49 \% \\
4.10 \%\end{array}$ & $\begin{array}{l}8.78 \% \\
3.19 \%\end{array}$ & $\begin{array}{l}4.28 \% \\
2.19 \%\end{array}$ \\
\hline $\mathrm{B}_{2} \mathrm{O}_{3}$ & $\begin{array}{l}\text { High } \\
\text { Low }\end{array}$ & $\begin{array}{l}9.3 \\
9.3\end{array}$ & $\begin{array}{l}8.78 \% \\
2.96 \%\end{array}$ & $\begin{array}{l}6.75 \% \\
2.23 \%\end{array}$ & $\begin{array}{l}3.18 \% \\
1.19 \%\end{array}$ \\
\hline $\mathrm{Al}_{2} \mathrm{O}_{3}$ & $\begin{array}{l}\text { High } \\
\text { Low }\end{array}$ & $\begin{array}{l}7.8 \\
7.8\end{array}$ & $\begin{array}{l}9.05 \% \\
2.72 \%\end{array}$ & $\begin{array}{l}7.15 \% \\
2.11 \%\end{array}$ & $\begin{array}{l}3.37 \% \\
1.32 \%\end{array}$ \\
\hline $\begin{array}{l}\text { Alkal ine } \\
\text { Earth Oxides }\end{array}$ & $\begin{array}{l}\text { High } \\
\text { Low }\end{array}$ & $\begin{array}{l}1.8 \\
1.8\end{array}$ & $\begin{array}{r}10.50 \% \\
2.50 \%\end{array}$ & $\begin{array}{l}8.15 \% \\
1.90 \%\end{array}$ & $\begin{array}{l}3.73 \% \\
0.87 \%\end{array}$ \\
\hline $\mathrm{ThO}_{2}$ & $\begin{array}{l}\text { High } \\
\text { Low }\end{array}$ & $\begin{array}{l}3.5 \\
3.5\end{array}$ & $\begin{array}{r}12.27 \% \\
4.13 \%\end{array}$ & $\begin{array}{l}9.46 \% \\
3.21 \%\end{array}$ & $\begin{array}{l}4.46 \% \\
2.21 \%\end{array}$ \\
\hline $\mathrm{P}_{2} \mathrm{O}_{5}$ & $\begin{array}{l}\text { High } \\
\text { Low }\end{array}$ & $\begin{array}{l}2.5 \\
2.5\end{array}$ & $\begin{array}{l}9.95 \% \\
2.68 \%\end{array}$ & $\begin{array}{l}7.47 \% \\
2.06 \%\end{array}$ & $\begin{array}{l}3.36 \% \\
0.95 \%\end{array}$ \\
\hline$U_{3} 0_{8}$ & $\begin{array}{l}\text { High } \\
\text { Low }\end{array}$ & $\begin{array}{l}0.5 \\
0.5\end{array}$ & $\begin{array}{r}13.34 \% \\
4.89 \%\end{array}$ & $\begin{array}{r}10.25 \% \\
3.94 \%\end{array}$ & $\begin{array}{l}4.33 \% \\
2.56 \%\end{array}$ \\
\hline Other & $\begin{array}{l}\text { High } \\
\text { Low }\end{array}$ & $\begin{array}{l}2.5 \\
2.5\end{array}$ & $\begin{array}{r}11.43 \% \\
3.44 \%\end{array}$ & $\begin{array}{l}8.75 \% \\
2.67 \%\end{array}$ & $\begin{array}{l}3.41 \% \\
1.52 \%\end{array}$ \\
\hline
\end{tabular}

(a) Low is $\operatorname{RSDA}=5 \%, \mathrm{RSDS}=1 \%, \mathrm{NA}=3$, and $N S=1$. High is $\mathrm{RSDA}=15 \%$, $\mathrm{RSDS}=1 \%, \mathrm{NA}=1$, and $\mathrm{NS}=1$.

(b) The relative standard deviation is the standard deviation represented as a percentage of the target concentration. 
Statistical analysis of the simulated data from the model revealed that decreasing the sampling and analytical uncertainty reduced significantly the batch-to-batch variability. Reducing waste variability, volume uncertainty, or batching errors did not significantly change batch-to-batch variability. These study results do not suggest that these three factors do not affect the batch-to-batch uncertainty for all elements besides the alkali oxides and alkaline earth oxides. The study shows only that decreasing the factors from their high levels to the low levels does not significantly affect the resulting glass composition. The three factors certainly remain sources of batchto-batch variability. However, these results indicate that to reduce the batch-to-batch variations, WVNS resources are best directed toward reducing sampling and analytical uncertainties.

Future simulations could be conducted to determine the appropriate sampling and analytical schemes required to obtain an acceptable glass composition variation. More exact estimates of the sampling and analytical uncertainty would be needed to determine a required sampling/analysis scheme.

\subsubsection{Development of Vitrification Mass Balance Flowsheet}

Three material balance programs using LOTUS $123^{\circ}$ spreadsheet programs were constructed that carry out WVDP vitrification mass balance calculations. The programs and included information are meant to provide information on process engineering and process stream properties to facilitate engineering/ flowsheet parametric studies. Each program performs three parallel mass balance calculations--a chemical balance, a radionuclide balance, and an equivalent oxides balance--in addition to providing calculated or input process properties.

The programs were structured into process area groupings based on available computer random access memory (RAM) and associated activities as follows:

(ब) Registered trademark of LOTUS Development Corporation, Cambridge, Massachusetts. 
- Hest Valley Waste Composition (WNIC) provides the compositions of tanks $8 \mathrm{D}-2$ and $8 \mathrm{D}-4$ contents by supernatant composition, sludge composition (supernatant- and soluble solids-free), and composite composition. The associated radionuclide content activities are included and decayed by the program to the year specified based on a parameter input.

- West Valley Tank Farm Processing (WVTFP) performs mass balance calculations for batch water washing the sludge in tank 8D-2 to remove sulfate and other water-soluble chemicals. A dilution model is used for calculations of solids washing. The tank 8D-2 supernate and sludge wash water are processed for cesium removal by ion exchange using a zeolite. The amount and composition of associated zeolite, cesium, water, and other materials placed in tank 8D-1 for recycle to tank $8 \mathrm{D}-2$ are estimated. The composite composition of tank 8D-1 contents, including the ion-exchange recycle material, chemical additions, and the existing corrosion products and water content in tank $8 \mathrm{D}-1$, is determined. The amount of sodium hydroxide required to neutralize the THOREX waste in tank 8D-4 is estimated. The resulting neutralized THOREX waste is transferred to tank 8D-2 with associated water flushes. This approach is equivalent to adding the required sodium hydroxide to tank $8 \mathrm{D}-2$, followed by adding the acid THOREX waste with associated water flushes to tank 8D-2 for neutralization. The washed sludge in tank 8D-2, the neutralized THOREX waste from tank 8D-4, and tank 8D-1 corrosion product/ion-exchange recycle material/chemical additions with associated flushes are combined in tank 8D-2 to provide the vitrification feed material.

- Hest Valley Vitrification (WVv) combines vitrification feed from tank 8D-2 with other vitrification system process wastes, such as SBS solution, HEME wash/drain solution, canister decontamination waste, and miscellaneous process and vessel decontamination wastes, in the CFMT for concentration. After CFMT contents are concentrated, the required glass-forming chemicals to achieve an ATM-10 glass composition are added to the CFMT as a slurry. After transfer to the MFT, the made up melter feed is transferred to the melter for vitrification. The molten glass is poured into canisters. The melter off gas (MOG), after air addition from melter/ turntable inleakage, film cooler, and pressure control air, is treated by quenching/scrubbing in the SBS and de-entrainment. The vessel vent air (after passing through a condenser) is combined with the partially treated MOG at this point, and the combined stream is further treated by particulate removal in the HEME, heated, and then double-filtrated by two HEPA filters. The MOG is finally heated for transfer to another building, where it receives final treatment to remove nonradioactive noxious gases and possibly iodine. Vitrification process wastes are defined and routed for recycle or disposal. 


\subsubsection{WVDP Vitrification Process Description Document}

The draft WVDP Vitrification Process Description document was completed and issued this year. The document describes the high-level radioactive waste vitrification process and its application at the West Valley Site.

The Vitrification Process Description document is intended to be used to orient staff and to provide flowsheet information for process engineering and for analyzing process operations to determine timing compatibility of process elements. The description was divided into two main sections:

- WVDP Mission - The project mission provides the context for developing the process design and operating guidelines.

- WVDP Vitrification Process Description - The process description describes the various process operations. Each description includes:

- system function

- process

- time cycle analyses (as appropriate).

The following process elements are described in detail:

- melter feed preparation system

- melter feed system

- melter/turntable system

- process off-gas system

- canister handling and inspection system

- canister decontamination system

- process waste handling system

- vitrification equipment maintenance.

Chemical usage and conditions in the process description may not match precisely those in the mass balance due to updated information and more detailed analyses provided in the West Valley Vitrification Process Description. 
- WVDP Vitrification Mass Balance - The vitrification mass balance presents the following elements:

- bases and assumptions

- mass balance

- mass balance discussions.

- WVDP Vitrification Sample Schedule - A representative process sample schedule is included to provide a basis for time cycle analyses and to include information for analytical capability preparation. The sample schedule contains information on sample frequency, analyses, and other requirements.

- Process Equipment Description - Major equipment systems in the vitrification process are physically described by providing data and figures on physical features.

\subsubsection{Slurry Homogeneity Testing of the West Valley Melter Feed Tank and Sampler System}

Full-scale tests performed in FY 1987 at West Valley using the MFT (Figure 1.27) were based on a PNL-prepared test $p l a n$. The test objectives were to 1) quantify the homogeneity of the melter feed slurry in the MFT, 2) determine the representativeness of the slurry sample obtained by the liquid-sampling system for the MFT, 3) determine the time required to resuspend and homogenize the melter feed slurry after a simulated unexpected power outage, and 4) verify the scale-up of the results from the bench-scale mixing study. Analysis and reporting of this work were completed in FY 1988 by Fow, Kurath, and Pulsipher (1989).

\subsubsection{Study Methods}

Two types of tests (homogeneity/sampling system tests and resuspension tests) were performed using three concentrations of simulated, nonradioactive melter feed slurry. The melter slurry concentrations tested included the reference melter feed, the reference melter feed concentrated to 75 vol\% (concentrated feed), and the reference melter feed diluted to 125 vol\% (dilute feed). The homogeneity/sampling system tests were performed to characterize the melter feed system and verify the bench-scale mixing data. The resuspension tests were performed to determine the time required to resuspend and uniformly mix the solids in the MFT after a simulated unexpected power outage. 

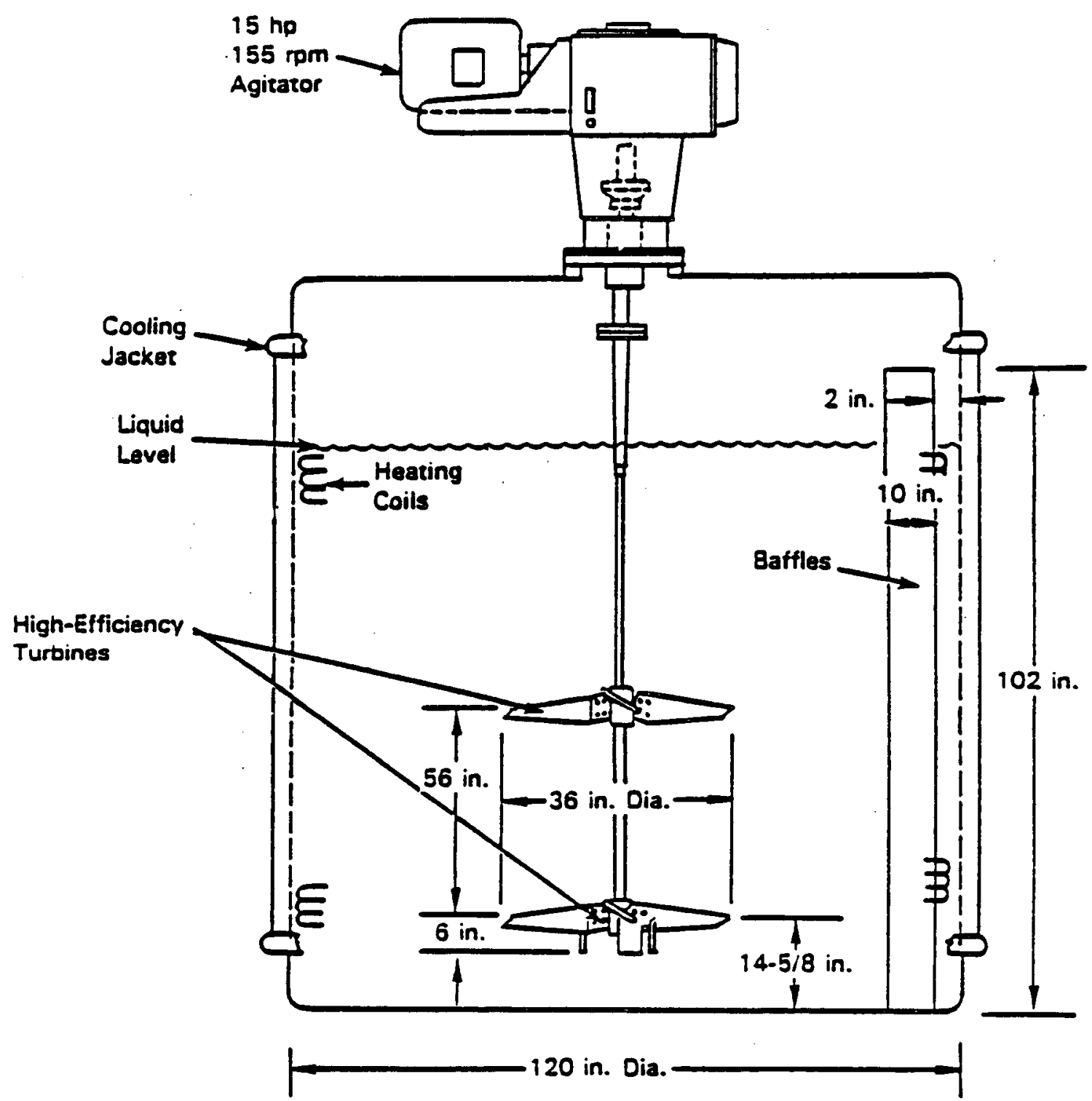

38806- i 52.004

FIGURE 1.27. Schematic of West Valley Melter Feed Tank

For the homogeneity/sampling system tests, slurry homogeneity was measured by comparing the average weight percent solids and the elemental concentrations of slurry samples taken from six sampling locations within the tank. The representativeness of the sampling system was determined by comparing the average weight percent solids and the elemental concentrations between the samples taken at six tank-sampling locations and those from the 
sampling system. For the resuspension tests, tank homogeneity was determined by comparing only weight percent solids of the slurry samples from within the tank.

The statistical design of the homogeneity/sampling system tests required 21 samples at each sampling location to attain a 95\% confidence level of detecting a difference of $>4.5$ elemental weight percent. The statistical design of the resuspension tests required six samples at each sampling location. Samples were taken from the tank and analyzed for total solids and elemental concentrations in a random order. All analyses were conducted at West Valley.

\subsubsection{Study Results}

Statistical data analyses were performed on as-analyzed and normalized values of the elemental concentrations; they are summarized in Table 1.7.

\section{TABLE 1.7. Results from Statistical Analysis of} Elemental Concentration Data

\begin{tabular}{|c|c|c|c|}
\hline \multirow[b]{2}{*}{$\begin{array}{c}\text { Slurry } \\
\text { Concentration }\end{array}$} & \multicolumn{3}{|c|}{ As-Analyzed Elemental Concentration, \% } \\
\hline & $\begin{array}{c}\text { Sampler } \begin{array}{c}B j a s \\
\text { Range }(a)\end{array} \\
\end{array}$ & $\begin{array}{l}\text { Tank Inhomogenejty } \\
\text { RSD (b) Range (c) } \\
\end{array}$ & $\begin{array}{l}\text { Analytical } \\
\text { RSD Range (d) }\end{array}$ \\
\hline Concentrated & $0.3-5.7$ & $0.0-1.3$ & $1.4-7.8$ \\
\hline Reference & $0.4-12.2$ & $0.0-0.0$ & $2.4-12.0$ \\
\hline \multirow[t]{2}{*}{ Dilute } & $2.1-29.2$ & $0.0-2.3$ & $2.0-20.7$ \\
\hline & \multicolumn{3}{|c|}{ Normalized Elemental Concentration, $\%$} \\
\hline Concentrated & $0.1-1.7$ & $0.0-0.7$ & $2.6-5.3$ \\
\hline Reference & $0.8-6.9$ & $0.0-0.0$ & $3.2-9.6$ \\
\hline Dilute & $0.2-13.9$ & $0.0-0.8$ & $4.2-16.1$ \\
\hline
\end{tabular}

(a) Sampler bias is the difference in elemental concentration between the average of the six tank-sampling locations and that of the liquid-sampling system.

(b) RSD: relative standard deviation.

(c) Tank inhomogeneity range is the variability among the six sampling locations.

(d) Analytical range is the variability in the analytical results for a particular sampling location. 
Four significant conclusions as follows can be drawn from the data:

1. Analysis of normalized values can sometimes mask interactions. It can be deceptive when certain conditions affect some elements but not others, or when they affect all elemental constituents similarly. This can have significant impact during feed makeup.

2. The 15-hp, single-speed (155 rpm) agitator installed in the MFT produces a homogeneous mixture for the three concentrations of simulated melter feed slurry used in these tests. Slurries with significantly greater settling rates may produce different results.

3. The liquid-sampling system used in these tests obtains samples that are up to $2.6 \%$ higher in total solids and are significantly different in certain elements.

4. The major source affecting accuracy of the results is the variability in replicate analytical measurements.

Other significant conclusions drawn from analyses of the data are as follows:

- After 4 days of settling in the MFT (simulating a loss of power), less than $2 \mathrm{hr}$ of agitation were required to resuspend and uniformly mix the slurries tested.

- Scale-up of the bench-scale tests was verified qualitatively. It was shown that the mixing system operated in the turbulent flow region and that the liquid in the tank was homogeneous. A precise verification of scale-up of bench-scale data was not possible due to dissimilarities between the bench- and full-scale mixing systems.

- The maximum flow rate of the ADS pump used for the sampling system does not achieve turbulent flow in a 0.5-in.-ID pipe; this may contribute to the nonrepresentative samples due to solids settling in the lines.

- The mixing Reynolds numbers calculated for the three concentrations of slurry tested were 1 to 2 orders of magnitude greater than the Reynolds number at which fully turbulent mixing is defined. This implies that the agitator speed could be reduced without affecting feed homogeneity in the MFT, if slurry settling rates are similar to those of the tested slurries. 
The following are recommendations to improve melter feed consistency and reduce the number of required analyses per sample:

- Much of the analytical uncertainty was due to long-term effects (e.g., lab conditions, calibration procedures). A statistical quality control program, such as is detailed in this study, would isolate and eliminate some major sources of variation. Reduced analytical uncertainty lowers the number of required analyses per sample, thereby reducing cost.

- Perform characterization tests on the actual liquid-sampling system to determine procedures that will provide a more representative sample. These tests should include evaluation of sample bottle design, sampling cycle times, minimum flow rates, and flushing requirements.

\subsubsection{Evaluation of Properties of Simulated West Valley Feed}

Physical properties of simulated West Valley slurries were characterized to help explain process results such as melter process rates, cold-cap behavior, and the extent of slurry suspension and mixing. Beginning with samples from the SF2 frit run in FY 1985, two samples each from 11 consecutive slurry-fed ceramic melter runs were evaluated. Qualitative observations and the measured values for the ratio of settled solids to total sample volume, $\mathrm{pH}$, density, and rheological properties were determined.

Table 1.8 summarizes the observed ranges for the properties noted and measured. Sample set SF7 exhibited a significantly higher ratio of solids to total volume, higher yield stress, and higher apparent viscosity. The lowest and highest $\mathrm{pH}$ values were observed for sample sets SF9 and SF4, respectively. Except for sample sets SF2 and SF3, a pseudohomogeneous mixture (fine dispersion) that remained stable for a minimum of $1 \mathrm{hr}$ was obtained upon shaking. Sample sets SF2 and SF3 were coarse dispersions of premade glass frit that separated into two phases (supernatant and solids) immediately after shaking. 


\section{TABLE 1.8. Summary of Property Ranges for} West Valley Feed Simulants

Physical Properties

Color (3)

Settling Rate

Mixture Type

Ratio Solids/Total Volume

Density, $\mathrm{g} / \mathrm{mL}$

$\mathrm{pH}$

Rheological Behavior (predominant)

Yield Stress, $\mathrm{Pa}$

Apparent Viscosity, CP
Observed Range

Grey, green-yellow, brick red

Immediate to stable for a minimum of $10 \mathrm{~min}$

Fine dispersion to two phases

0.25 to 0.76

1.2 to 1.37

12.80 to 2.87

Pseudoplastic and yieldpseudoplastic

0 to 1.59

4.33 to 22.2

2.84 to 11.98

Table 1.9 summarizes the values collected for the volume of settled solids to total sample volume, and the sample pH, density, and rheological properties.

The sample densities range from 1.2 to 1.37. In general, they increased with sampling date, indicating progressively higher solids loadings in the feed simulations.

The $\mathrm{pH}$ values range from 2.87 to 12.8 , with the highest observed for the SF4 sample set. Samples SF2 and SF3 have an average pH of $10 \pm 0.4$. In general, acidity increases with sampling date; the possible exception is the last sample set, SF $10 A$ and $B$.

The rheological data were evaluated on the basis of a power law fit. The power law as applied to rheological measurements is defined as

$$
\gamma=\gamma_{y}+K D^{n}
$$


TABLE 1.9. Summary of Measured Values for West Valley Feed Simulants

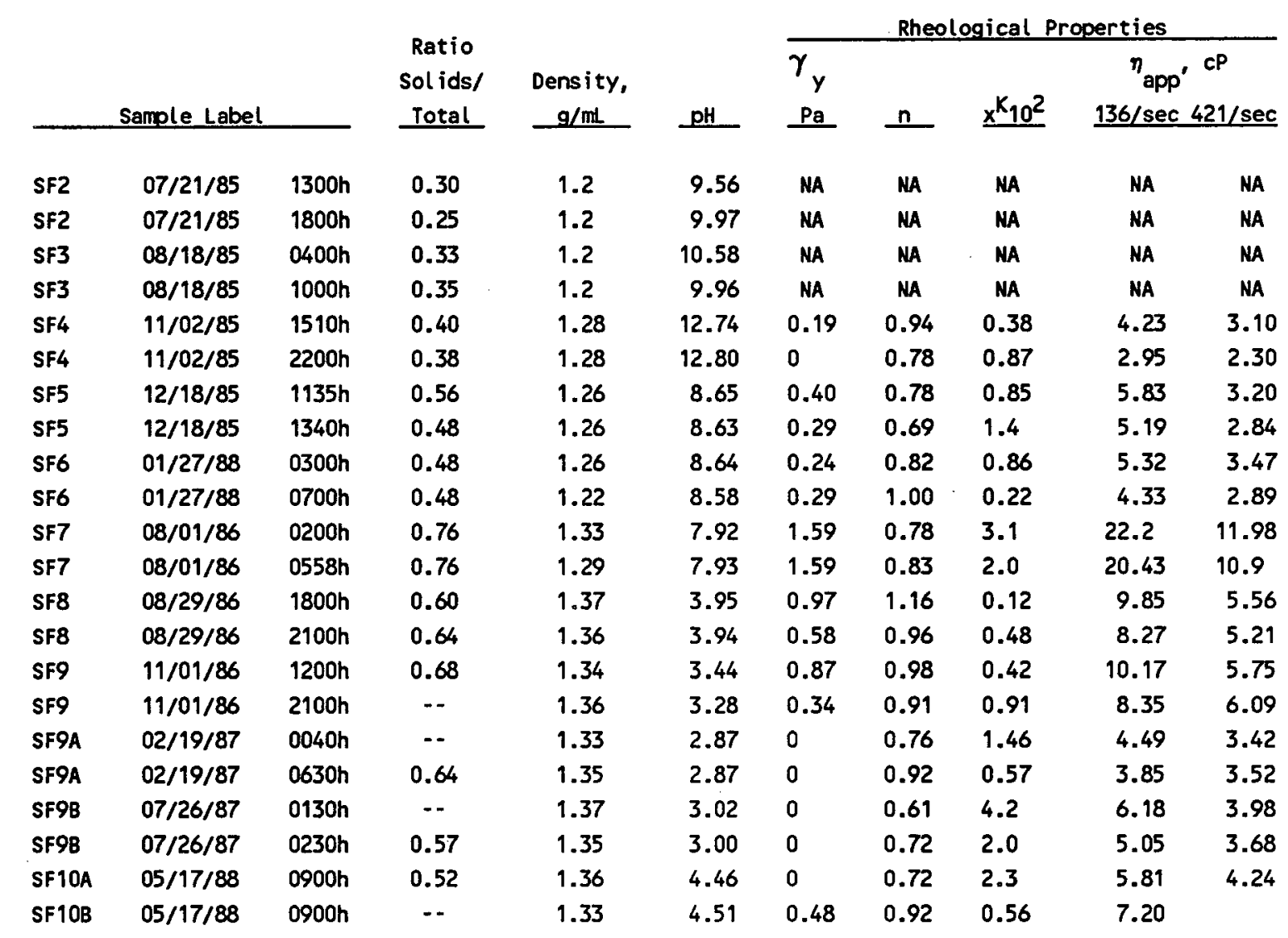

where $\gamma=$ shear stress

$$
\begin{aligned}
\gamma_{y} & =\text { yield stress } \\
D & =\text { shear rate } \\
K & =\text { consistency factor } \\
n & =\text { flow index. }
\end{aligned}
$$

Several types of rheological behaviors were observed. Most of the samples exhibit pseudoplastic or yield-pseudoplastic behavior $(n<1.00)$. The yield stress and apparent viscosity for sample set SF7 is greater than or equal to two times that of the other samples. Most samples have apparent viscosities (measured at spindle rotational speeds of 136 and $421 \mathrm{sec}^{-1}$ ) of about 3 to $5 \mathrm{CP}$ and yield stresses $<1 \mathrm{~Pa}$. The rheological behavior of sample set SF7 may be attributed to the relatively large volume of undissolved solids 
present. Due to the rapid settling rate and the presence of visibly large particles, rheological properties could not be measured for the frit slurry sample from SF2 and SF3.

of the measured values, the density, $\mathrm{pH}$, and viscosity most clearly indicated the changes in slurry makeup as the runs occurred. Density values increased to a high of about $1.35 \mathrm{~g} / \mathrm{mL}$, consistent with siurry oxide loadings of 450 to $550 \mathrm{~g} / \mathrm{L}$. Over time the value for $\mathrm{pH}$ can be affected by dissolution of materials, which can shift the solution $\mathrm{pH}$. The samples collected from SFCM runs conducted over the last 2 years had $\mathrm{pH}$ values on the order of 3 to 4.5. This range of $\mathrm{pH}$ is what would be expected for slurries containing little, if any, excess nitric acid and is consistent with the current flowsheet being tested.

Viscosity can have a large effect on melter processing rate if it is high enough to impede distribution of the slurry over the surface of the cold cap and glass. The viscosity values measured for the samples tested indicated that the slurry tested in SF7 had a significantly higher viscosity than did the other samples received for analyses. Although lower than SF7, the SF8 and SF9 samples also had viscosity values significantly higher than did the remaining samples. Based on these results, the slurries for runs SF7, SF8, and SF9 should not have covered the cold cap and glass surface as readily as the other feed slurries. The causes for the higher viscosity do not correlate with the other physical properties measured. Therefore, the viscosities were probably affected by the selection of chemical feed stocks or the use of higher concentrations of soluble chemicals such as sugar.

\subsection{PRODUCT QUALIFICATION - M. A. H. Reimus, L. R. Bunne11, G. B. Mellinger, and G. F. Piepe]}

The product qualification subtask of the West Valley Support Project at PNL supports the waste form qualification (WFQ) efforts at WVNS. In support of these efforts, waste forms are being tested to determine their chemical durability, and the effects of composition, ferrous/ferric ratio (redox state), thermal history, and groundwater. 
During FY 1988, $16 \mathrm{glasses}$ were fabricated based on statistically selected compositional variations of the reference West Valley waste glass composition, WV-8801. The glasses were examined for the presence of secondary (crystalline) phases, and the glass compositions were analyzed. Chemical durabilities were characterized using 28-day Materials Characterization Center (MCC)-1, and 7- and 28-day MCC-3 leach tests.

The results of testing conducted during FY 1988 and FY 1987 were compiled in a topical report (Reimus et al. 1988) to which the reader is referred for details. A summary of the results obtained during FY 1988 and FY 1987 follows.

Glasses were tested using modified MCC -3 and MCC-1 test methods. Replicates were run for each glass composition. These 7 - and 28-day tests are useful for initial studies and are applicable to WFQ. Tests of longer duration are needed, however, to determine the long-term durability of these glasses.

During FY 1987, two sets of compositional variation glasses were fabricated and leach-tested with the 7-day MCC-3 test to determine the effect of composition on waste glass chemical durability. The first set of glasses consisted of eight variations of West Valley ceramic melter reference glass WVCM-47 while the second set consisted of 16 variations of reference glass WVCM-50. The set of eight glasses was selected to investigate the effects of specific single-component and other variations (from WVCM-47) of interest. The set of $16 \mathrm{glasses}$ was selected using statistical experimental design techniques so as to provide the most information about the effects of varying composition within the specified compositional variation region. Boron releases of the glasses ranged from $34 \%$ above to $29 \%$ below the WVCM-50 value. A linear mixture model fitted the data very well and demonstrated that varying composition has a statistically significant effect on chemical durability (as quantified by boron release in the 7-day MCC-3 leach test). The fitted linear mixture model can be used to predict the effects on durability of varying the composition within the region investigated.

All glasses tested had observed normalized release rates below the Waste Acceptance Preliminary Specifications. The applicable specification states 
that the normalized release rates of sodium, silicon, boron, uranium, and cesium must be below $1 \mathrm{~g} / \mathrm{m}^{2}$-day or $28 \mathrm{~g} / \mathrm{m}^{2}$ in a 28 -day MCC-1 test in deionized water at $90^{\circ} \mathrm{C}$. However, the $95 \%$ upper confidence 1 imit of the release over the compositional region investigated is $29.3 \mathrm{~g} / \mathrm{m}^{2}$, which accounts for short- and long-term within-lab variability in the leach testing and chemical analysis procedures. The $95 \%$ upper confidence 1 imit increases to $41.1 \mathrm{~g} / \mathrm{m}^{2}$ when including a $20 \%$ lab-to-1ab variability. Both of these latter values are above the proposed limit.

Several options--including a smaller compositional region, need for statistical variability consideration, reduction in analytical variability, investigation of an additional composition region, or reassessment of the proposed limit--should be further investigated. It is clear that lab-to-1ab and within-lab uncertainties should not be ignored, either in characterizing the chemical durability of a region of glass compositions, or in the specification of an acceptance criterion.

The results of the microstructural characterization of the 16 WV-8801 glass variations indicate that the compositional changes within the region being characterized by PNL do not produce marked changes in the nonglass phases found in these glasses. Though some glass-to-glass variations occur, differences are subtle and the total amount of crystalline material is quite sma11. Further study of the formation of these crystals should be undertaken, however, because they could cause sludge to form in the melter.

Four glasses with identical composition (WVCM-50, which was developed earlier) but with different redox states were tested to determine the effect of redox state on chemical durability. Analyses of the normalized elemental releases from the glasses indicate that redox state does not have a statistically significant effect on their chemical durability.

WVCM-50 was subjected to two types of heat treatment, then leach-tested to determine the effects of thermal history on glass chemical durability. Two types of heat treatment were used: slow cooling--simulating glass canister cooling--and isothermal. Cubic spinel-type crystals $\left[(\mathrm{Fe}, \mathrm{Ni})(\mathrm{Cr}, \mathrm{Fe})_{2} \mathrm{O}_{4}\right]$ and $\mathrm{ThO}_{2}$ crystals were observed in all treated specimens. Hematite-type crysta]s $\left[(\mathrm{Cr}, \mathrm{Fe}) \mathrm{O}_{3}\right]$ and ruthenium inclusions were observed in 
most specimens. Rapidly cooled glass specimens were more durable chemically than the more slowly cooled specimens. Based on boron release, the slow-cool heat treatments caused a maximum decrease in durability of $40 \%$. The isothermal heat treatments caused a maximum decrease of $100 \%$. Isothermal treatments of $725^{\circ} \mathrm{C}$ for $\geq 12 \mathrm{hr}$ caused the most consistent decrease in durability, $44 \%$.

West Valley reference glass (WVCM-50) was tested in four groundwaters to determine their effect on chemical durability. The four groundwaters tested were PBB1 and PBB3 (bedded salt site groundwaters), J-13 wel1 water (a tuff groundwater), and GR-4 (a basalt groundwater). Groundwater type was found to definitely affect chemical durability, increasing it as much as a factor of 5 , based on boron release, over durability in deionized water. The 7-day boron releases from the glass were $0.045 \mathrm{~g} / \mathrm{m}^{2}$ in PBB1, $0.060 \mathrm{~g} / \mathrm{m}^{2}$ in PBB3, $0.076 \mathrm{~g} / \mathrm{m}^{2}$ in $\mathrm{J}-13$ water, $0.092 \mathrm{~g} / \mathrm{m}^{2}$ in $\mathrm{GR}-4$, and $0.209 \mathrm{~g} / \mathrm{m}^{2}$ in deionized water.

\subsection{REFERENCES}

Fow, C. L., D. E. Kurath, and B. A. Pulsipher. 1989. Evaluation of the Mixing System for the West Valley Melter Feed Hold Tank. PNL-6724, Pacific Northwest Laboratory, Richland, Washington.

Reimus, M. A. H., G. F. Piepel, G. B. Mellinger, and L. R. Bunnell. 1988. West Valley Glass Product Qual ification Durability Studies, FY 1987-1988: Effects of Composition, Redox State, Thermal History, and Groundwater. PNL-6723, Pacific Northwest Laboratory, Richland, Washington. 


\subsection{FABRICATION OF ISOTOPIC HEAT AND RADIATION SOURCES}

L. K. Holton, Jr. - Manager

\subsection{OBJECTIVE}

The objective of this task is to fabricate 30 isotopic heat and radiation sources (canisters) containing prescribed amounts of ${ }^{90} \mathrm{Sr}$ and ${ }^{137} \mathrm{Cs}$ in a borosilicate glass for the Federal Republic of Germany's (FRG) disposal studies. The work of this task is part of a bilateral exchange agreement between the U.S. Department of Energy (DOE) and the German government to help jointly demonstrate the liquid-fed ceramic melter under actual radioactive conditions. During FY 1988 the primary objective of the FRG Canister Fabrication Task was to complete the closure, decontamination, and characterization of the 30 isotopic heat sources that had been produced in the B-Cell radioactive liquid-fed ceramic melter (RLFCM) during FY 1986 and FY 1987. This task included completing the functional testing and installation of equipment systems for welding, electropolishing, and characterization in A-Ce11, B-Ce11, and the air lock of the 324 Building. It also required staff training, preoperational reviews and approval of program readiness.

The data from this work will provide future users of high-level waste canister handling technology with information to aid in planning, design, and operation of these systems.

\subsection{SUMMARY}

The Pacific Northwest Laboratory (PNL), under contract to the U.S. DOE, has produced 30 isotopic heat sources (canisters) for the FRG to be used in repository testing there. PNL staff filled, closed, and decontaminated the canisters by remote operations. The 30 canisters were fabricated (filled) in three separate processing campaigns in FY 1986 and 1987 using the RLFCM to produce a borosilicate glass. Within the borosilicate glass matrix radiochemical constituents $\left({ }^{137} \mathrm{Cs}\right.$ and ${ }^{90} \mathrm{Sr}$ ) were immobilized to yield a product with a predetermined decay heat and surface radiation exposure rate.

During FY 1988 the canisters were lid-welded using a gas tungsten arc welding process. Leak tightness of the canister lid weld was verified by a 
helium leak test. The leak rate of each canister was found to be no greater than $2.4 \times 10^{-8} \mathrm{~atm}-\mathrm{cc} / \mathrm{sec}$, which was less than the leak rate criterion of $10^{-7} \mathrm{~atm}-\mathrm{cc} / \mathrm{sec}$.

The top, sides, and bottom of the canisters were decontaminated by electropolishing. All canisters were decontaminated to surface smear contamination levels of less than $33 \mathrm{~Bq} / 100 \mathrm{~cm}^{2}$ beta-gamma radiation. No significant alpha contamination was observed on surfaces.

The canisters were characterized in five tests: 1) surface temperature measurement, 2) surface radiation exposure rate, 3) gamma energy scanning, 4) canister mass determination, and 5) gauge testing. The surface temperatures of the canisters ranged from a minimum average temperature of $133^{\circ} \mathrm{C}$ to a maximum average temperature of $205^{\circ} \mathrm{C}$. All but eight of the canisters had surface exposure rates of 218,000 to $320,000 \mathrm{R} / \mathrm{hr}$. Results from gamma energy scanning of the canisters correlated well with previous knowledge of the canisters' radiochemical characteristics. The average glass mass in the canister was $158 \mathrm{~kg}$, and the average canister fill volume was $60.6 \mathrm{~L}$. Al1 canisters passed easily through the ovality gauge. (For greater detail regarding this work, see PNL-6790 by Holton et al.)

The FRG also requested PNL to 1id-weld, decontaminate, characterize, and provide two additional filled canisters. It was agreed that PNL would provide these two canisters that had been specially instrumented to study the effect of glass cooling rates on glass cracking (Brouns and Powe 11 1988).

\subsection{INTRODUCTION}

Since 1973 the liquid-fed ceramic melter (LFCM) process for vitrifying high-level liquid wastes (HLLW) to borosilicate glass has been under development and testing in the United States. Its early success and inherent simplicity led to its adoption as the reference HLLW vitrification process in the U.S., Japan, and the FRG. The LFCM is the Department of Energy's reference process for $\mathrm{planned}$ defense and commercial nuclear waste solidification facilities, including the West Valley Demonstration Project, the Hanford Waste Vitrification Plant (HWVP), and the Defense Waste Processing Facility (DWPF) at Savannah River. 
Because of the LFCM's wide acceptance as the reference waste vitrification process in the U.S., DOE requested that PNL design, construct and operate a prototypical radioactive pilot-scale waste solidification facility employing the LFCM process. Pilot-scale radioactive testing is used to validate the design and operating data being applied to the three productionscale projects. The RLFCM will also provide needed documentation of design, data, and operating experience for use by architect-engineers involved with future commercial waste treatment facilities. The RLFCM equipment was installed in FY 1984 (Burkholder and Rus in 1985) and underwent shakedown testing in FY 1985 using higher levels of activity in each test. In FY 1986 preparation of isotopic heat and radiation sources for the FRG began. These sources using ${ }^{90} \mathrm{Sr}$ and ${ }^{137} \mathrm{Cs}$ as the active isotopes in borosilicate glass are to be used as part of a repository testing program in the Asse Salt Mine located in northeastern West Germany.

Decontamination, characterization and storage of the canisters of waste glass are necessary components of the RLFCM program. This activity requires the use of hot-cell space because the glass contains large quantities of radioactivity. The 324 Building's A-Ce11, adjacent to B-Ce11 where the RLFCM is located, was selected for this work. Cleanout and renovation of A-Cell has been necessary to make space available as the cell contained obsolete equipment used in previous programs. Extensive radionuclide decontamination of the cell has been necessary to ensure that canisters decontaminated for shipment are not recontaminated during interim storage.

The 30 isotopic heat and radiation sources (canisters) were produced

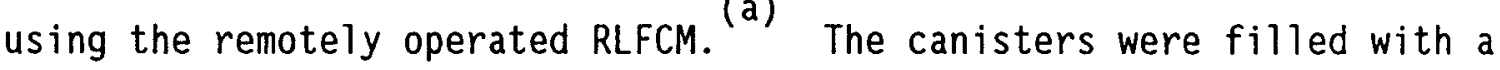
borosilicate glass in PNL's radiochemical engineering cell complex in the 324 Building, where the RLFCM, along with associated supporting equipment, was located in the largest of four hot cells. This equipment included the feed makeup and feed system, the canister handling and storage systems, and the off-gas treatment system of the RLFCM. After all 30 canisters had been

(a) For accounts of earlier work in this program, the reader is referred to prior annual reports in this series, PNL-6325 and PNL-6686, and to quarterly progress reports PNL-6320-1, -2, -3 , and -4 . 
filled, the lids were welded on using a remotely operated welding system, and the canisters were then decontaminated using an electropolishing process. The canisters were physically characterized using a series of nondestructive tests and measurements.

After the welding of the canister lid to the canister, it was passed into an air lock between the hot cell containing the vitrification equipment and the cell containing the decontamination equipment. In the air lock the integrity of the lid weld was verified using a helium leak-detection system and the canister surface exposure rate was measured.

The surfaces of the canisters were decontaminated using an electropolishing process. The remaining physical measurements were performed in the decontamination cell before the canisters were placed in a water-cooled storage rack, where they will remain until shipment to the FRG.

\subsection{CANISTER CLOSURE - R. F. K1ein, D. 0. Jenkins, and D. L. Alexander}

The FRG canisters were stored in B-Cell of the 324 Building hot-cell complex (Figure 2.1) after being filled with borosilicate glass. Each canister was encased by an overpack with a protective lid and placed in a specially designed canister storage rack. Before welding operations were begun, a11 equipment was installed by the end of the first quarter of 1988 and staff training and operational readiness reviewed and approved by midFebruary 1988.

The first steps of canister closure and decontamination were to retrieve each canister from storage, clean the lid weld surface for welding, measure the void height between the top of the glass surface and canister lid flange, calculate the void volume and place a calibrated helium capsule containing a known quantity of helium in the void space, and weld the lid onto the canister. A gross helium leak test and visual examination of the weld were then completed. The canisters were then rinsed with water to remove any loose contamination before being sent to the air lock to complete a sensitive helium leak test to verify weld integrity. 


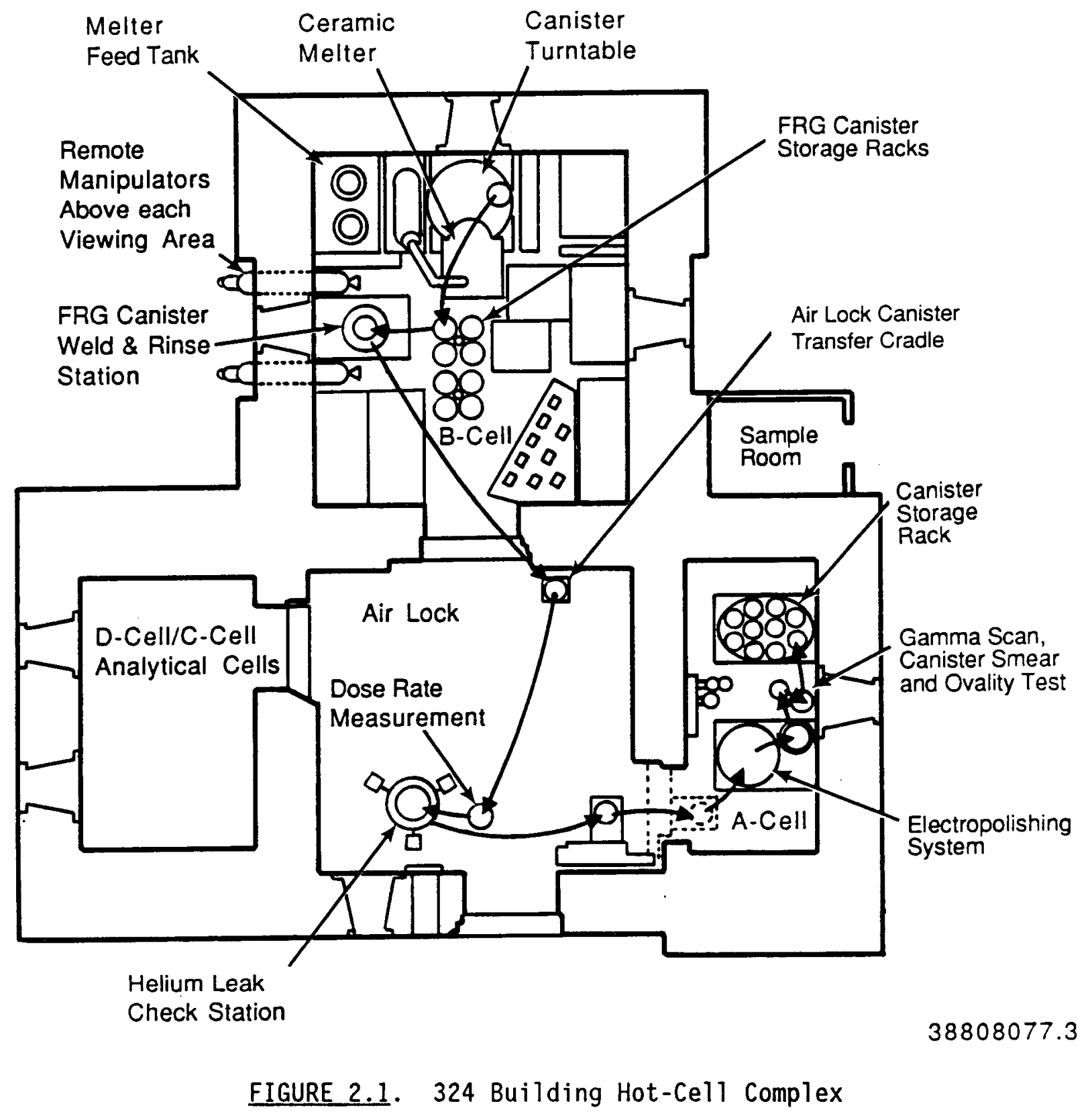

\subsubsection{Helium Capsule Filling}

A helium leak detection system was used to verify the leak tightness of the lid closure weld on each canister. This was done by filling a special gas cylinder with helium which would leak at a predetermined rate. This source capsule was then placed in the void space of an FRG canister prior to welding. After welding, the capsule was allowed to build up pressure in the 
canister void space. The leak tightness of the canister was then determined by checking the outside of the weld for escaping helium.

The helium source capsule (Figure 2:2) consisted of a 300-cc gas cylinder with a tapered glass capillary sealed in one end. The cylinder was filled with helium and sealed. The helium then slowly leaked out through the glass capillary. This slow leak rate ensured that the capsule would still be leaking well after the canister lid was welded. The fill pressure of each capsule was calculated using the canister void height such that once all the helium had leaked into the void space of the welded canister, the total pressure in the void would be $<5.6 \mathrm{~atm}$, the maximum allowable pressure.

Each helium capsule was filled by mounting it to a manifold consisting of a series of valves and pressure gauges, a calibrated volume, a helium source, and a vacuum source (Figure 2.3). The capsule was calibrated by filling it with helium to $1 \mathrm{~atm}$ and then recording the leak rate of the helium into the calibrated volume. This was done by monitoring the pressure increase in the calibrated volume over a given time. The capsule was then

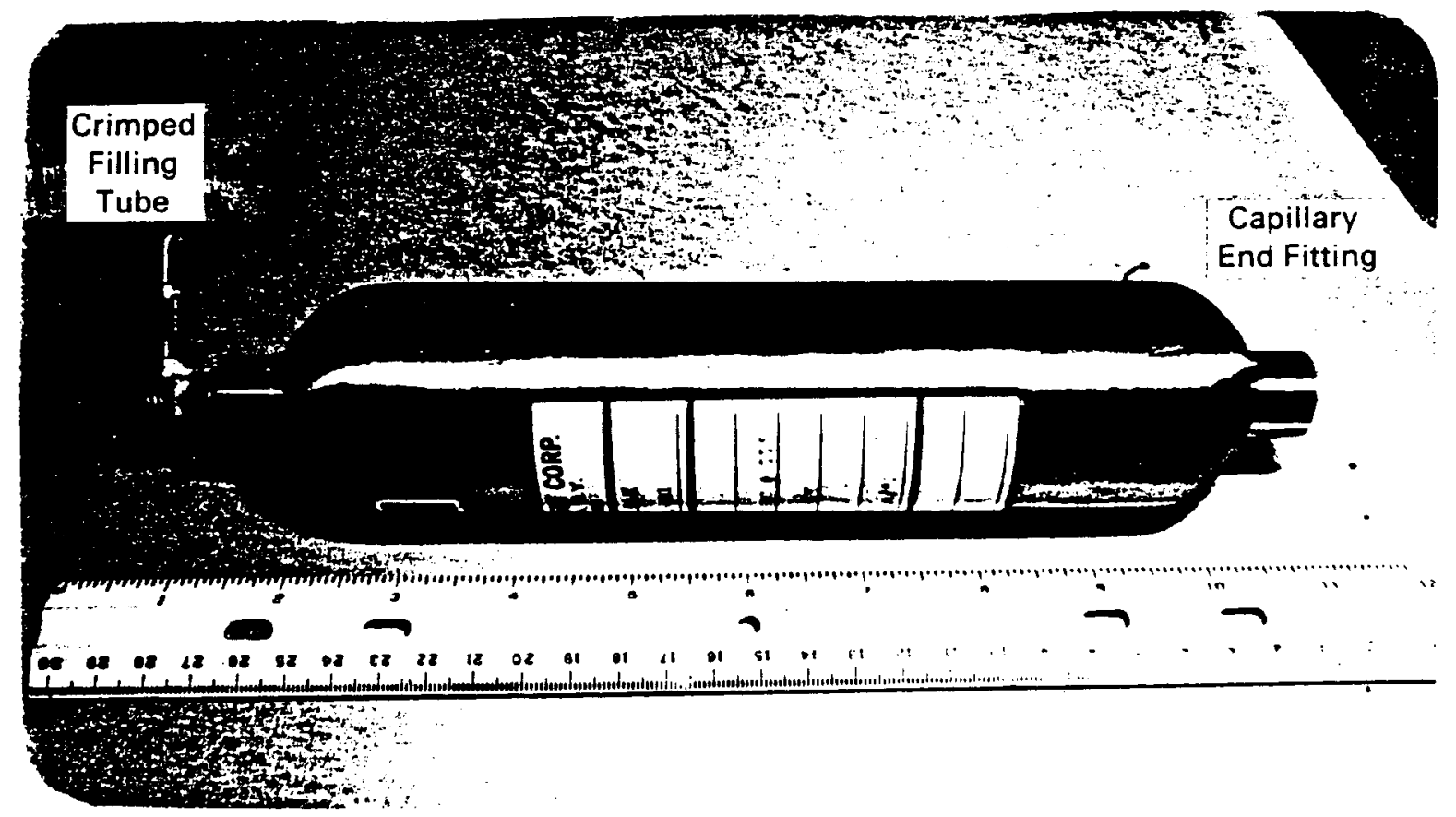

$8702985-70 \mathrm{cn}$

FIGURE 2.2. Hel ium Source Capsule 


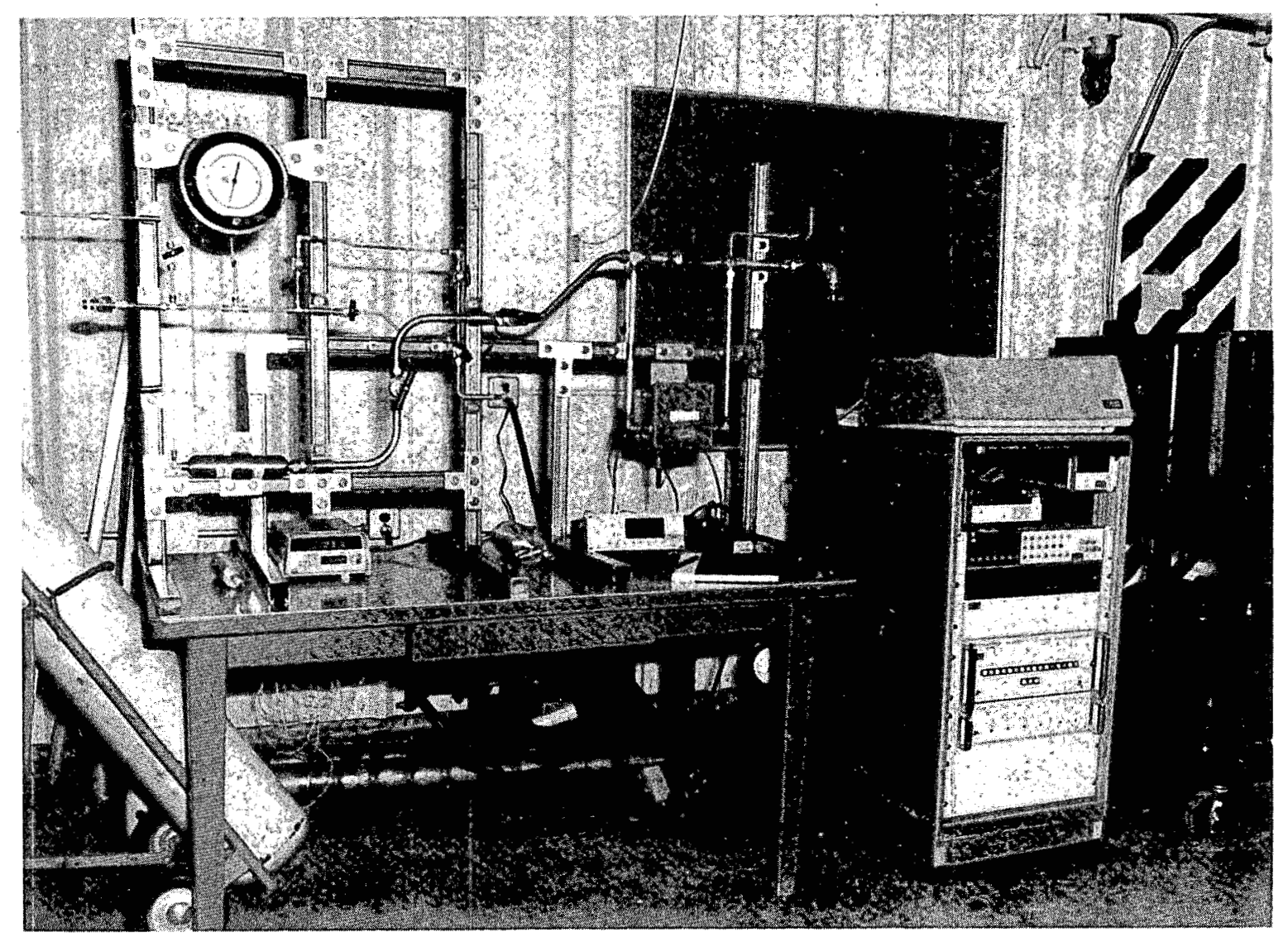

$8702985-20 \mathrm{cn}$

FIGURE 2.3. Helium Capsule Filling Manifold

filled to its final pressure (20 to $62 \mathrm{~atm})$, and the leak rate was again calculated. With the records of the leak rates of each capsule used for the 30 canisters as well as the times at which the capsule was filled, placed in the FRG canister, and welded, the canister void pressure could be calculated at any time after a canister was welded.

\subsubsection{Weld Preparation}

Sequentially, each canister in its overpack was moved from its in-cell storage position to a weld/rinse station in B-Cell. The protective $1 \mathrm{id}$ and the weld protector ring placed previously on the canister were then removed using a special yoke and the overhead crane. 
Next the void height between the top of the glass surface and the top of the canister was measured with a ruler at four places and in the center. An average value of the five measurements was determined, and the void volume and its uncertainty were calculated from the void height measurement. This void volume was used in determining the fill pressure for the helium capsule.

The canister flange was cleaned by using a stainless steel wire brushing wheel on a pneumatic grinder. The grinder was powered by a cylinder of breathing air located outside the hot cell. Breathing air was used to eliminate the possibility of contaminating the flange with oil or water. The inside surface of the flange near the weld joint and the top of the flange on both sides of the groove were thoroughly brushed. The groove itself was cleaned using a manipulator-held stainless steel brush. After brushing, the flange area was blown with breathing air to remove loose particulate and was visually inspected with a television camera.

The flange 1 id was thoroughly cleaned outside the cell using acetone and then alcohol. The cleaned lid and the precalibrated and filled helium capsule were then transferred into the cell. The helium capsule was placed into the canister, and the lid was set on the flange. A gross helium cell background reading was taken, and then a gross helium reading was taken over the canister to ensure that the capsule was releasing helium (see Section 2.5.1). At this point the welding head was swung over the canister lid from its storage location and lowered into position on the canister lid. Figures 2.4 and 2.5 are photographs showing the welding head and the welding power supply.

Weld specifications required a flange and 1 id temperature of $80^{\circ} \mathrm{C}$ to $250^{\circ} \mathrm{C}$ before any welding could take place. Therefore, the flange and lid temperatures were measured with a contact thermocouple. In general, $15 \mathrm{~min}$ were required to heat the canister lid through contact with the canister flange to within acceptable welding temperatures.

\subsubsection{Welding}

A11 canisters were lid-welded using an autogenous gas tungsten arc (GTA) welding process. After the welding head was set in place on the lid, the 


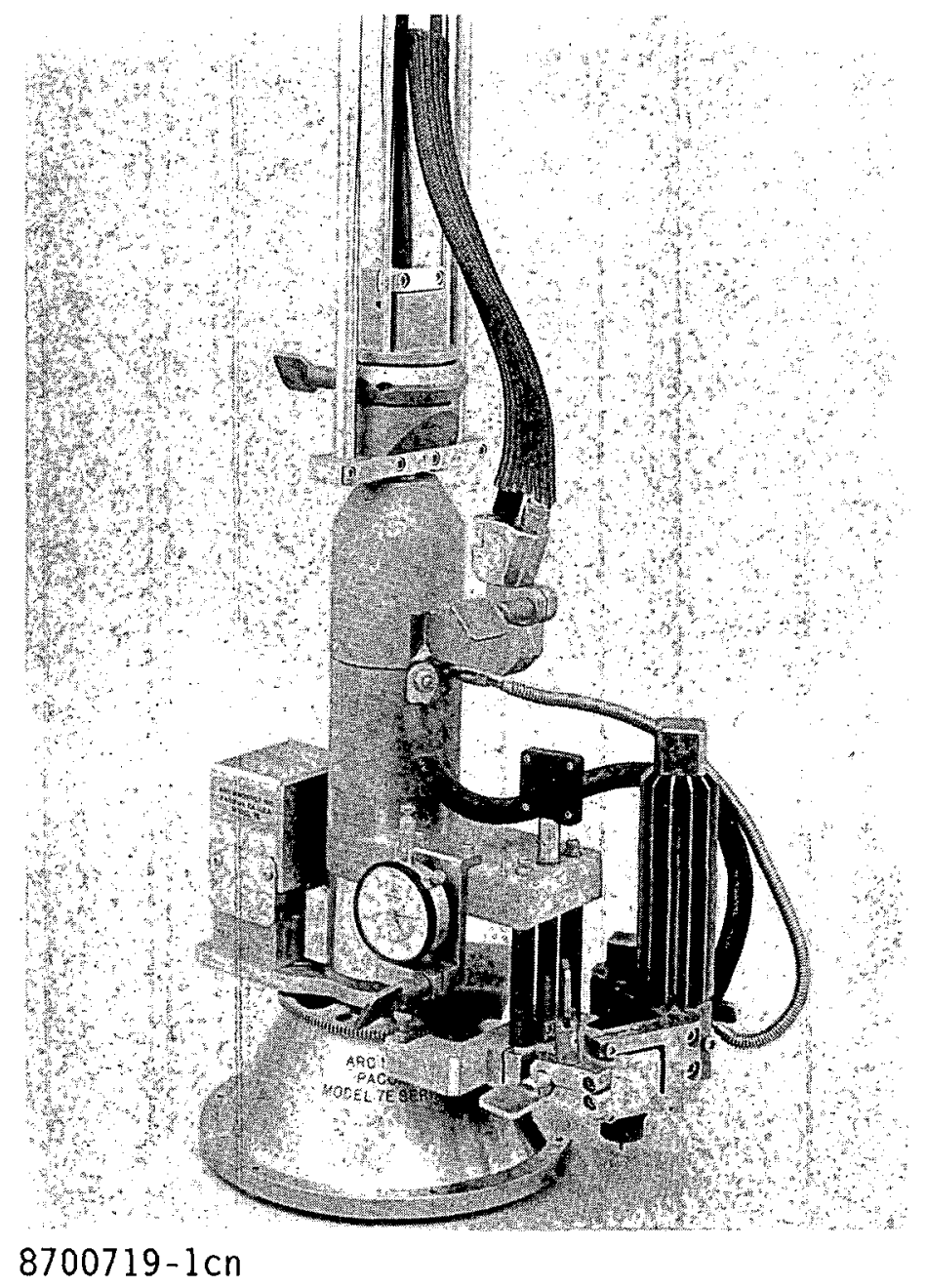

\section{FIGURE 2.4. Remote Canister Lid Welder}

alignment of the electrode tip with the weld joint was checked in two locations $180^{\circ}$ apart. This checking and any subsequent adjustment to the welding head were made by remote viewing through a Rees TV camera. Along with checking the electrode alignment, the arc gap (or the distance between the end of the electrode and the canister lid) was adjusted. This was accomplished by moving the electrode down until it touched the lid, completing an electrical circuit which turned on an audible alarm. The electrode was then adjusted upward to the predetermined arc gap distance. This distance was measured by a dial indicator mounted on the welding head which measured vertical movement of the electrode holder. After these adjustments were made 


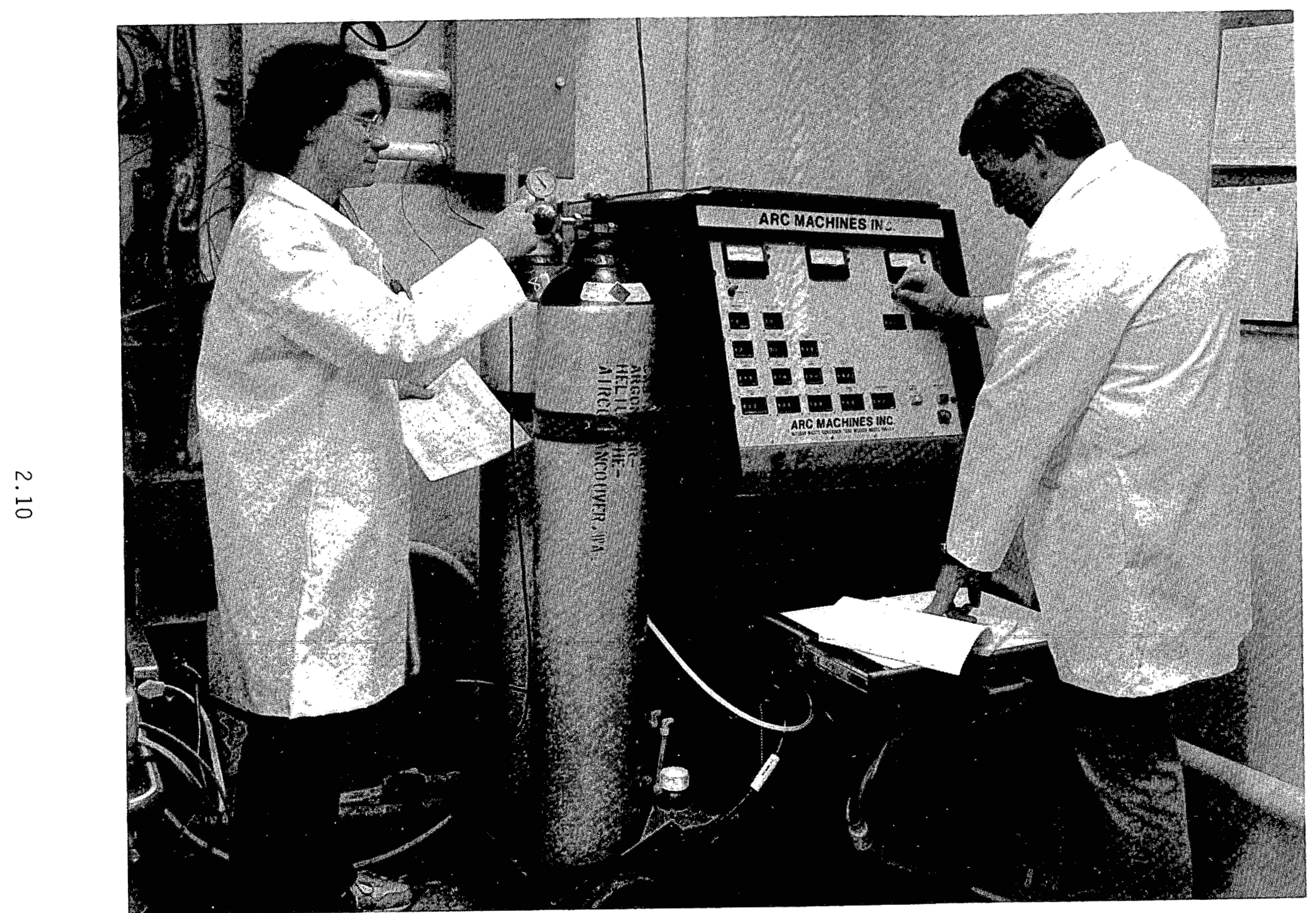

$8801711-13 \mathrm{cn}$

FIGURE 2.5. Setting Parameters on Welding Power Supply 
and the flange and dial temperatures were determined to be within the acceptable limits, welding of the lid to the flange was begun.

Prior to lid-weld closure the lid was first tack-welded to the flange in three locations spaced $120^{\circ}$ from each other. The final closure weld was then started midway between the first and last tack weld so that the weld overlap could be observed clearly.

The welding of the radioactive waste-filled canisters began on February 17, 1988, and was completed on March 31, 1988. The welder electrode was replaced after the seventh, fourteenth, and twenty-third welds.

Welding progressed well up to the sixth canister, when the quality of the welding arc deteriorated after the weld had gone about halfway around the weld joint. The arc color changed to orange, and the arc expelled bits of materials. The completed weld bead width and height varied, and the bead laps were not uniform. Test welds were made to learn the cause of the problem, but no positive determination could be made. As experience had shown that the most likely cause was inadequate inert gas cover of the welding arc, three corrective steps were taken: 1) the inert gas supply tube from the power supply to the welding head was changed, 2) the inert gas cylinder was changed, and 3) the inert gas regulator/flowmeter was changed. The welding electrode was also changed. Three test welds were then made and all were acceptable.

Welding of the canisters began again and continued without incident until the fourteenth canister, just after replacement of the welding electrode holder and electrode. The arc color during the tack welds was abnormal, and weld material spattered, resulting in blackish tack welds. The inert gas shielding of the arc was obviously inadequate. The inert gas supply tube between the power supply and the welding head was again replaced, but tests showed that the problem still existed. Then it was found that the new electrode holder had been received from the manufacturer with the locating pin $180^{\circ}$ out of position and prevented the inert gas from entering the electrode holder. The holder was replaced, the canister tack welds were thoroughly brushed, and an acceptable canister seal weld was made. The next sixteen canisters were welded without problems. It should be noted that some 
weld beads contained a significant number of "slag islands," which are caused by impurities in the base metal composition.

\subsubsection{Weld Inspection}

During each weld, a continuous chart recording of the arc voltage, arc current, and rotational speed of the welding head was made. The date, canister number, and time of weld start was written on each recording. After each weld, the welding head was lifted off the canister lid and moved to its storage position. A gross helium leak check of the weld was then performed. After the gross leak check was completed, the weld head was visually inspected using a Rees TV camera.

\subsubsection{Canister Rinsing}

Each FRG canister was rinsed to remove any loose contamination before being transported from B-Cell to the air lock cell. After the 1id weld was inspected, the canister was lifted from the overpack using a 3.4-m-1ong lifting yoke attached to the B-Cell 6-ton crane. It was moved to the east end of the cell cautiously to avoid contact with any material that might further contaminate the canister. The overpack yoke was attached to the 3 -ton crane, and the empty overpack was moved from the welding station to its storage location. The spray cone apparatus was then placed onto the weld station and the water supply piping connected. The canister was centered over the rinse cone, and the valves to the water supply were opened. The canister was lowered and raised through the rinse cone once before being transported immediately to the air lock.

The spray cone apparatus consists of a containment vessel with a 24-in.-dia pipe ring located 2 in. down from the opening at the top. This ring, constructed of 1 -in. Sch 40 pipe, contains four evenly spaced spray nozzles which are pointed inward. One other spray nozzle, located at the bottom of the rinse tank, sprays directly upward and is used to rinse the bottom of the canister. 
2.5 WELD VERIFICATION - M. L. Elliott, J. L. Duce, G. N. Buck, and J. F. Hutchens

The canister lid weld was verified by first performing a gross leak check in B-Cell immediately after welding and then a more sensitive helium leak check in a special helium leak-test vessel located in the air lock. The maximum helium leak rate specification of the canisters was $10^{-7} \mathrm{~atm}-\mathrm{cc} / \mathrm{sec}$.

\subsubsection{Gross Leak Check}

After the canister lid weld was visually inspected, it was tested for gross leaks using a Gow-Mac ${ }^{\text {TM }}$ gas sniffer (Figure 2.6). This sniffer works by drawing gas through a small hose into a thermal conductivity cell that detects the presence of helium from leaks as small as $10^{-5} \mathrm{~atm}-\mathrm{cc} / \mathrm{sec}$. The canister weld was tested by placing a cone of sheet metal over the lid and then positioning the sniffer probe over a small hole located at its apex. If helium were escaping from the weld, it would rise to the top of the cone and be sampled by the sniffer, the cone would be removed, and the probe would be moved slowly along the weld bead to locate the leak source. This was not done as no leaks were detected on any of the 30 canisters.

Originally the entire sniffer unit was placed in B-Cell to detect gross leaks, but high radiation exposure rates there quickly damaged the system's electronics. A new system was then designed to place the sniffer unit in a shielded sample room adjoining B-Cell (Figure 2.7). A small vacuum pump located in the sample room drew air in from B-Cell via a small flexible hose. The sniffer probe was mounted into the pump inlet line to sample the incoming gas for helium. The exhaust from the pump was then returned to the cell to complete the closed loop. The end of the flexible hose in B-Cell was positioned over the canister the same as when the entire sniffer probe was in B-Ce11. This system proved very sensitive to helium when the vacuum pump's flow rate was adjusted correctly.

Before each canister was welded, the sniffer was tested by placing the capsule in the canister and positioning the lid for welding. The sheet metal cone was then placed above the canister, and the sample hose was set above

TM Trademark of Gow-Mac Instrument Co., Bridgewater, New Jersey. 


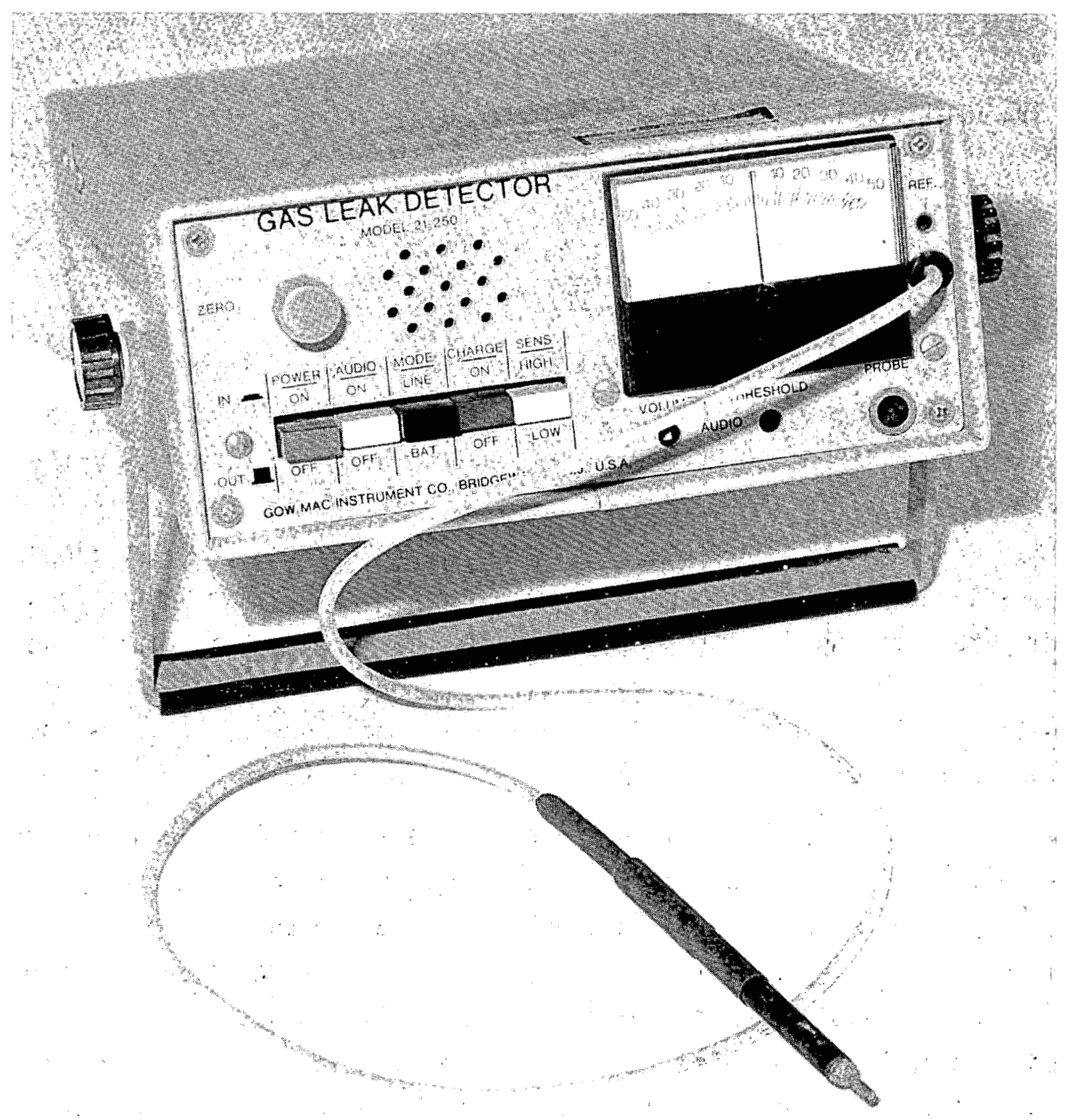

8802971

\section{FIGURE 2.6. Gow-Mac Gas Sniffer}

the cone tip. Helium escaping through the unwelded lid seam was easily detected after the capsule had built up sufficient pressure in the canister void space. The sniffer could also be tested by placing the sample hose by the GTA welder electrode and turning on the cover gas, which contained $75 \%$ helium. 


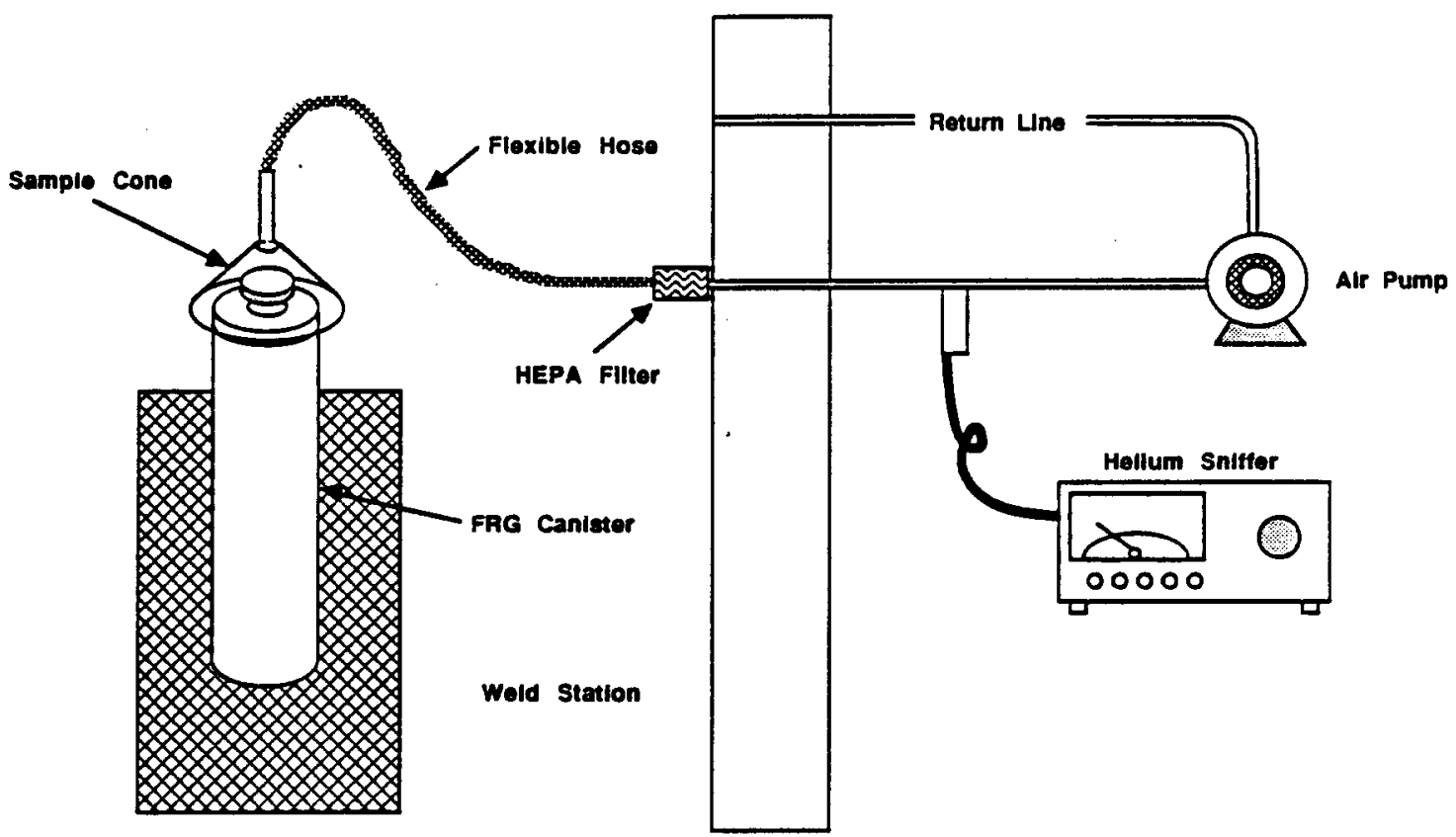

B-Cell

Sample Room

38805-167.3M

FIGURE 2.7. B-Cell Sniffer Arrangement

\subsubsection{Fine Leak Check}

After the canisters were welded and rinsed in B-Cell, they were transferred to the air lock (Figure 2.1), where they remained for about $24 \mathrm{hr}$ to allow sufficient helium to leak from the capsule and thus increase the pressure sufficiently in the canister void space. The canisters were then subjected to a more sensitive leak test in which they were sealed inside a $160-L$ cylindrical vacuum vessel (Figure 2.8 ). The vacuum vessel was then evacuated and the effluent tested for the presence of helium using a mass spectrometer leak detector that detects leak rates as $10 \mathrm{w}$ as $10^{-9} \mathrm{~atm}-\mathrm{cc} / \mathrm{sec}$ (Figure 2.9).

Before each canister was tested, the leak detector was calibrated using a standard helium source capsule with a known leak rate to determine the detector's sensitivity. This leak was connected to the detector, which was outside the air lock. The detector's sensitivity was normally $-5 \times 10^{-10} \mathrm{~atm}-\mathrm{cc} / \mathrm{sec} / \mathrm{unit}$. The entire system was calibrated once each week 


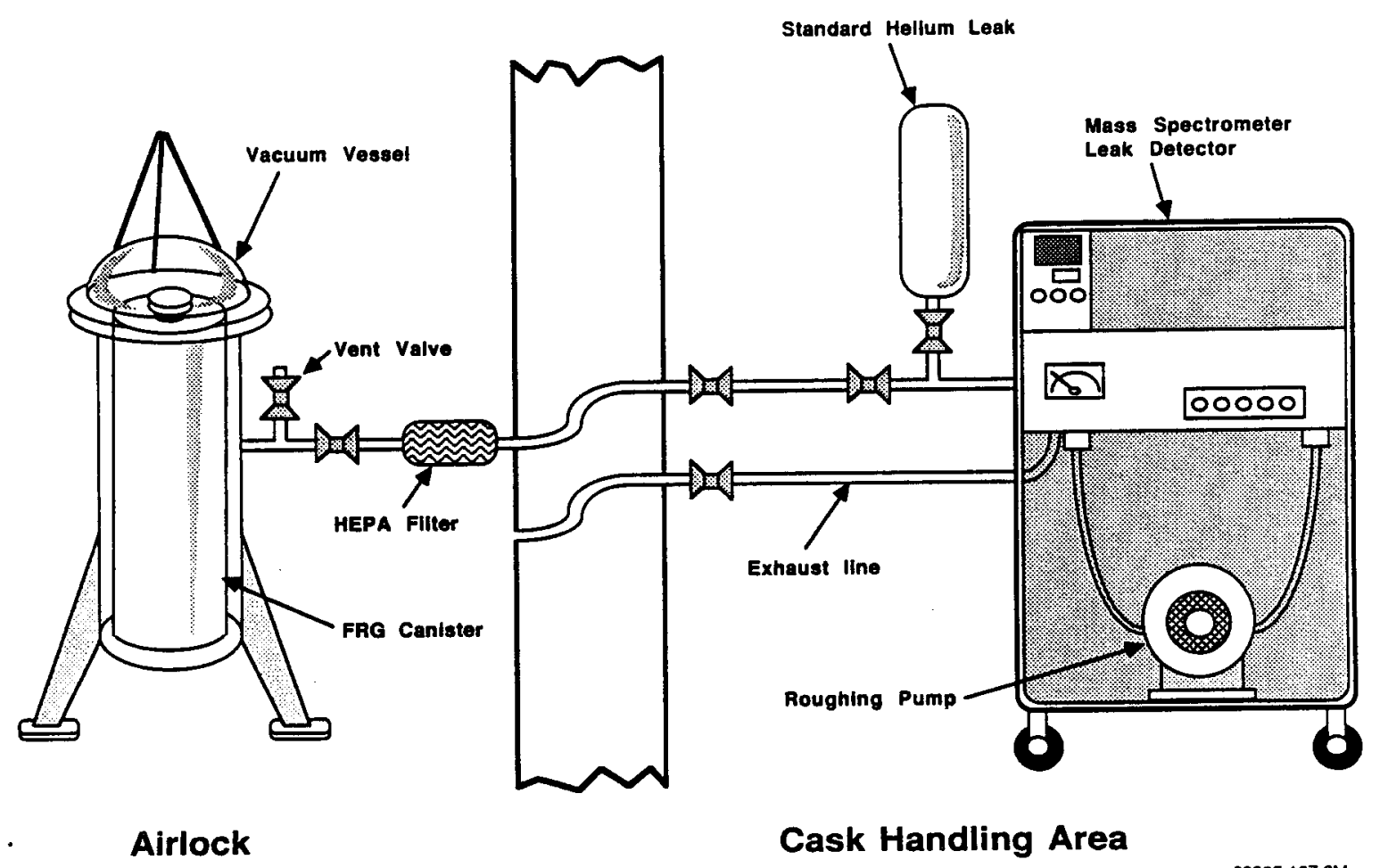

38805-167.2M

FIGURE 2.8. Helium Leak Detection System

by $p l a c i n g$ another standard leak source inside the vacuum vessel in the air lock and evacuating the vessel. The response of the leak detector was used to calculate the experimental leak rate of the source, and this was compared to the actual value. The actual standard leak rate was

$5.7 \times 10^{-8} \mathrm{~atm}-\mathrm{cc} / \mathrm{sec}$, and the value calculated each week was between 5 and $7 \times 10^{-8} \mathrm{~atm}-\mathrm{cc} / \mathrm{sec}$.

Each FRG canister was tested by first placing it in the vacuum vessel and sealing the vacuum vessel lid. The vessel was then evacuated down to $10 \mu \mathrm{m}$ of mercury using the roughing pump on the leak detector. This step usually took 1 to $2 \mathrm{hr}$ because the vessel was large and lengthy tubing connected it to the detector. When the pressure was below $10 \mu \mathrm{m}$, the effluent stream was shifted to the mass spectrometer and the pressure was reduced below $1 \mu \mathrm{m}$ using a diffusion pump. A gross leak rate could then be calculated by comparing the detector's response for the canister to that for the standard leak. The canister was then removed from the vacuum vessel, and the 


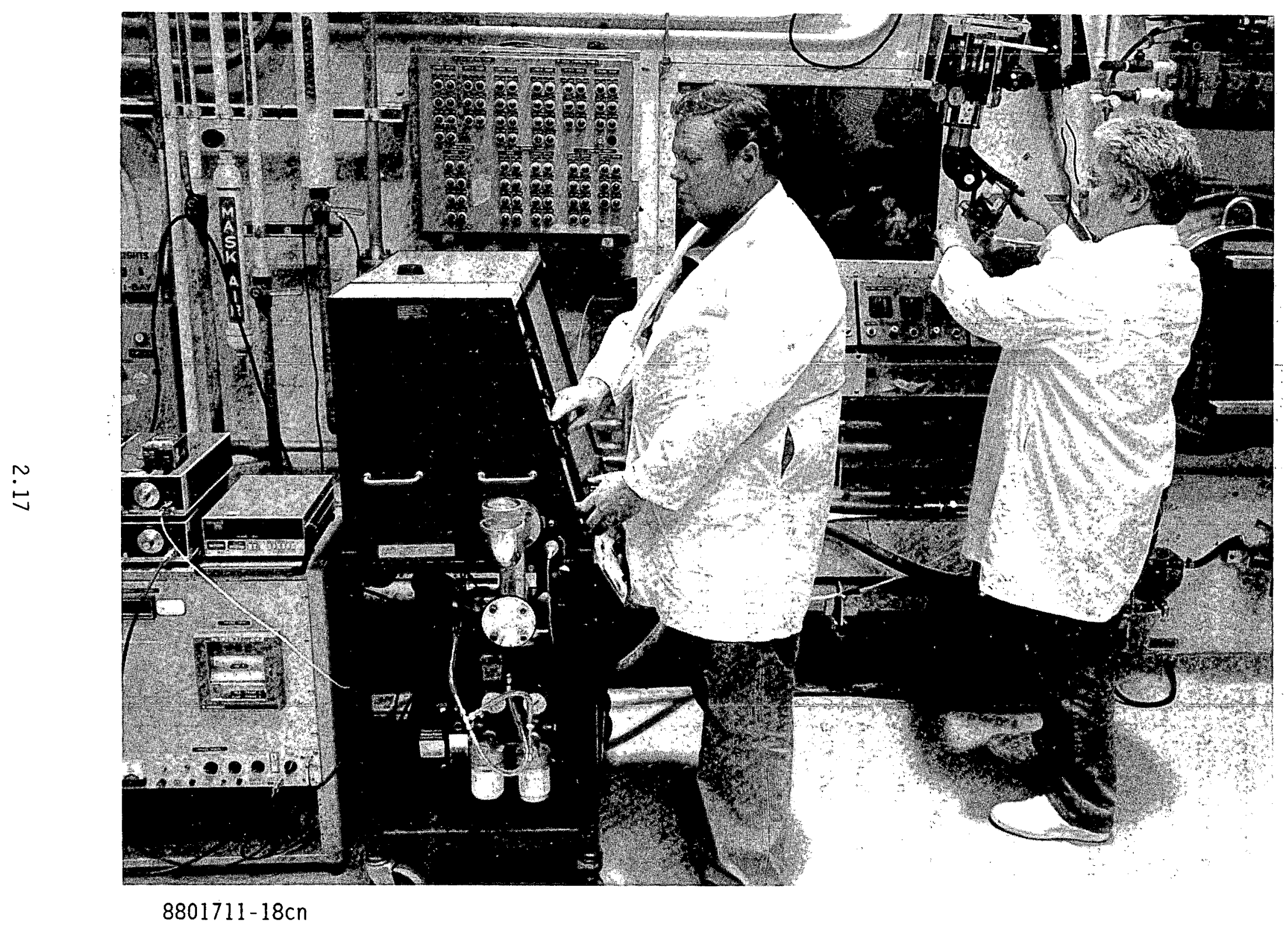

FIGURE 2.9. Helium Leak Test Being Performed 
lid of the vessel was resealed. The empty vacuum vessel was then evacuated and its effluent was shifted to the mass spectrometer in the same manner as when the canister was in it. The response of the leak detector to the empty vessel was recorded and converted to a leak rate. This served as a background for the system. The net leak rate for the canister was then calculated by subtracting the background for the empty vessel from the gross leak rate. The net leak rate is the portion of the gross leak rate attributed to the canister.

The average net leak rate for the 30 canisters was $2.4 \times 10^{-9} \mathrm{~atm}-$ $\mathrm{cc} / \mathrm{sec}$, and the maximum value was $2.4 \times 10^{-8} \mathrm{~atm}-\mathrm{cc} / \mathrm{sec}$. This value is well below the maximum allowable FRG limit of $10^{-7} \mathrm{~atm}-\mathrm{cc} / \mathrm{sec}$. For five of the 30 canisters the net leak rate was negative. This occurred because the vacuum vessel had to be vented between the background and gross leak rate readings so that the canister could be removed from it. For these five canisters it apparentiy caused a change in the vessel background reading, but the differences were very small.

A computer program was written to calculate the canister void pressure versus time when given the canister void volume, helium capsule characteristics, capsule filling time, capsule emplacement time, and welding time. It was used to determine the time required before the helium capsule built up enough pressure in the canister void to allow leak testing. The program also converted the experimentally determined leak rate to the leak rate that would be observed if the canister were at ambient conditions of $25^{\circ} \mathrm{C}$ and $1 \mathrm{~atm}$ differential pressure. This was done because the specified criterion of $10^{-7} \mathrm{~atm}-\mathrm{cc} / \mathrm{sec}$ maximum leak rate was at ambient conditions and not those of the individual canisters.

A second computer program was written to determine the equivalent measurable leak rate that would be present at the time of detection for the given conditions of each canister (void temperature and pressure and capsule pressure) if there were an actual leak at a rate of $10^{-7}$ atm-cc/sec at ambient conditions $\left(25^{\circ} \mathrm{C}\right.$ and $\left.1 \mathrm{~atm}\right)$. These calculations were then repeated for a leak rate of $10^{-8} \mathrm{~atm}-\mathrm{cc} / \mathrm{sec}$ at ambient conditions. Figure 2.10, a graph showing canister processing sequence numbers versus the various leak 


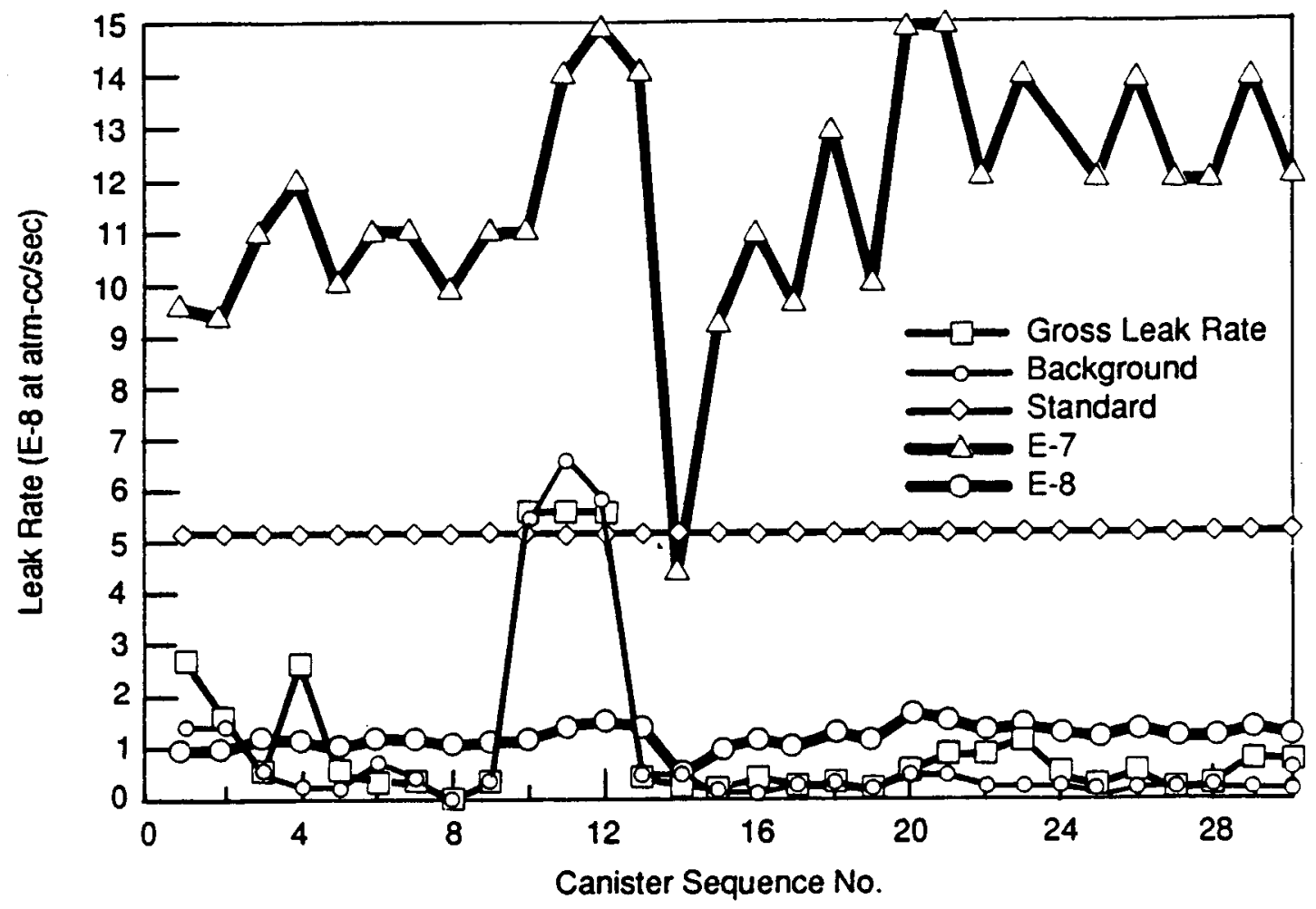

FIGURE 2.10. Leak Detection Computation Results

rates, provides these computational results. Leak rates are at the conditions (temperature, void pressure, viscosity, etc.) of the various canisters, not at ambient. The line labeled E-7 represents the equivalent measurable canister leak rate for a $10^{-7} \mathrm{~atm}-\mathrm{cc} / \mathrm{sec}$ leak at ambient conditions, and the line labeled E-8 represents that for a $10^{-8} \mathrm{~atm}-\mathrm{cc} / \mathrm{sec}$ leak at ambient conditions. For instance, if a canister had a $10^{-7} \mathrm{~atm}-\mathrm{cc} / \mathrm{sec}$ leak rate at $25^{\circ} \mathrm{C}$ and $1 \mathrm{~atm}$ differential pressure, what would this leak rate be at the actual testing conditions of $300^{\circ} \mathrm{C}$ and $0.8 \mathrm{~atm}$ differential pressure of canister 19 ? Plotted against this group of data are the gross leak rate, the vacuum vessel background, and the standard leak reading (the standard helium leak used to calibrate the leak detector each day). This standard is a constant rate of $5.2 \times 10^{-8} \mathrm{~atm}-\mathrm{cc} / \mathrm{sec}$, which generally corresponded to a leak detector reading of 100 units. Thus the leak detector's sensitivity was in the range of $5 \times 10^{-10} \mathrm{~atm}-\mathrm{cc} / \mathrm{sec} / \mathrm{unit}$. 
Two anomalies are seen in Figure 2.10. The first is the unusually high gross leak rates and background leak rates for canisters 10 through 12 , due to contamination in the vacuum vessel causing a high background reading. It poses no problem because the net leak rate (gross minus background) was still near zero. The second anomaly is the low equivalent measurable leak rate calculated for the $10^{-7} \mathrm{~atm}-\mathrm{cc} / \mathrm{sec}$ leak rate of canister 14 . This was due to a low void pressure in the canister at the time; this rate was far above the leak detector's limits and would have been easily detected.

Figure 2.10 confirms that all canister leak rates were well below the requirement of $10^{-7} \mathrm{~atm}-\mathrm{cc} / \mathrm{sec}$, and in most cases one to two orders of magnitude lower. The graph shows also the leak detector's fine sensitivity.

2.6 ELECTROPOLISHING - J. E. Surma, R. P. Allen, G. H. Bryan, S. D. Halstead, S. J. Morris, and F. E. Haun

Electropolishing technology was used to decontaminate the top, sides, and bottom of the FRG canisters. The specifications for smearable contamination on the FRG canisters required the surface contamination to be below $22,000 \mathrm{dpm} / 100 \mathrm{~cm}^{2}\left(370 \mathrm{~Bq} / 100 \mathrm{~cm}^{2}\right)$ beta-gamma and $2200 \mathrm{dpm} / 100 \mathrm{~cm}^{2}$ $\left(37 \mathrm{~Bq} / 100 \mathrm{~cm}^{2}\right.$ ) alpha.

\subsubsection{System Description}

The 30 filled and sealed FRG canisters were decontaminated using an electropolishing system located in A-Cell of the 324 Building (Figure 2.1). Shown in Figure 2.11 is the equipment arranged in the decontamination cel1. This equipment includes the electropolisher, an equipment storage rack, and a water-cooled storage vessel in which the canisters were placed after electropolishing. The major components of the electropolishing system are shown in Figure 2.12. The electropolishing tank, constructed from Hastelloy $\mathrm{C}-276^{\circledR}$, holds up to $1000 \mathrm{gal}$ of electrolyte and is provided with systems to heat, cool, filter, and mix the electrolyte. The electrolyte used was $85 \mathrm{wt} \%$ phosphoric acid.

(B) Registered trademark of Cabot Corporation, Kokomo, Indiana. 


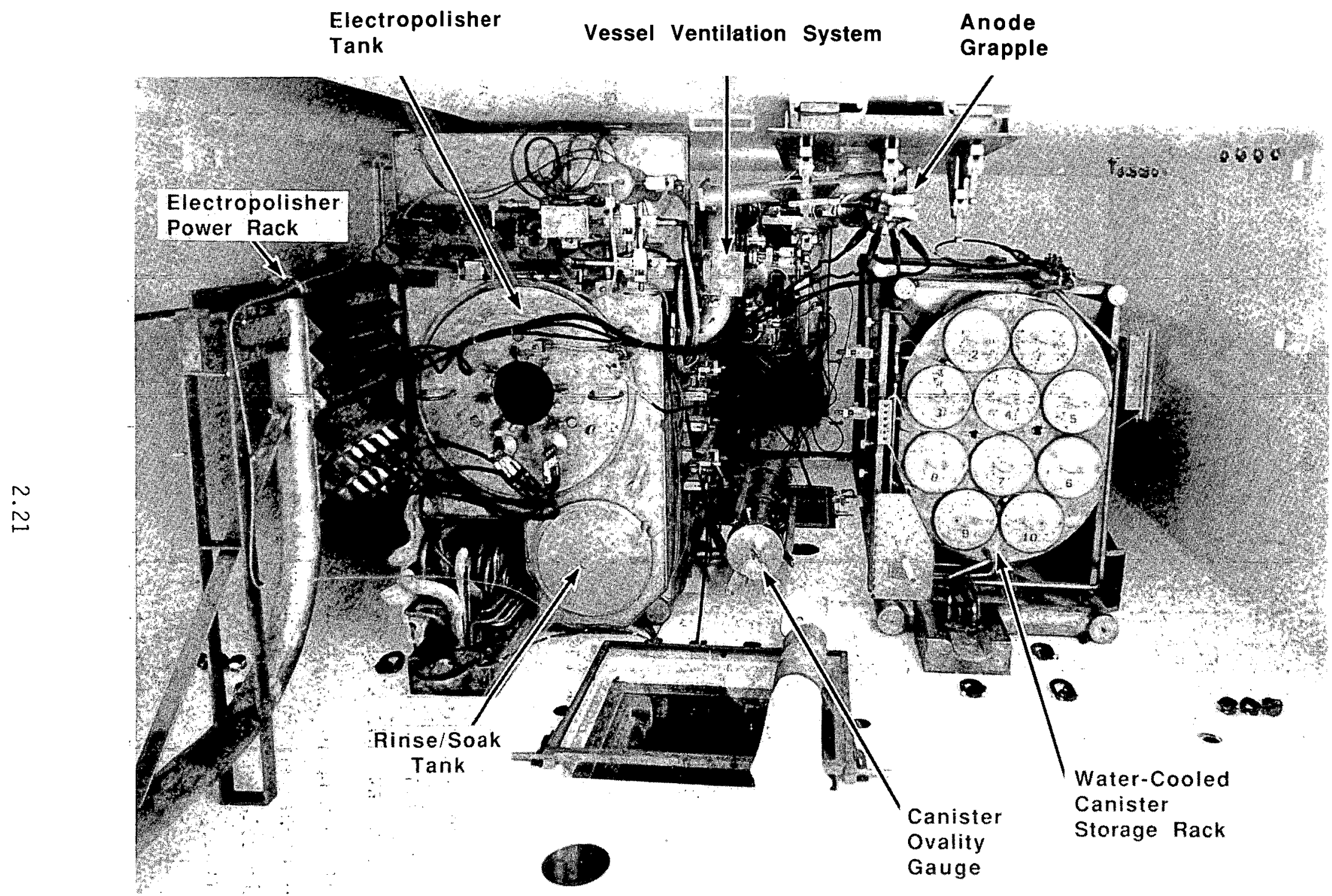

89020223-1

FIGURE 2.11. Overhead View of the Canister Decontamination Cell 


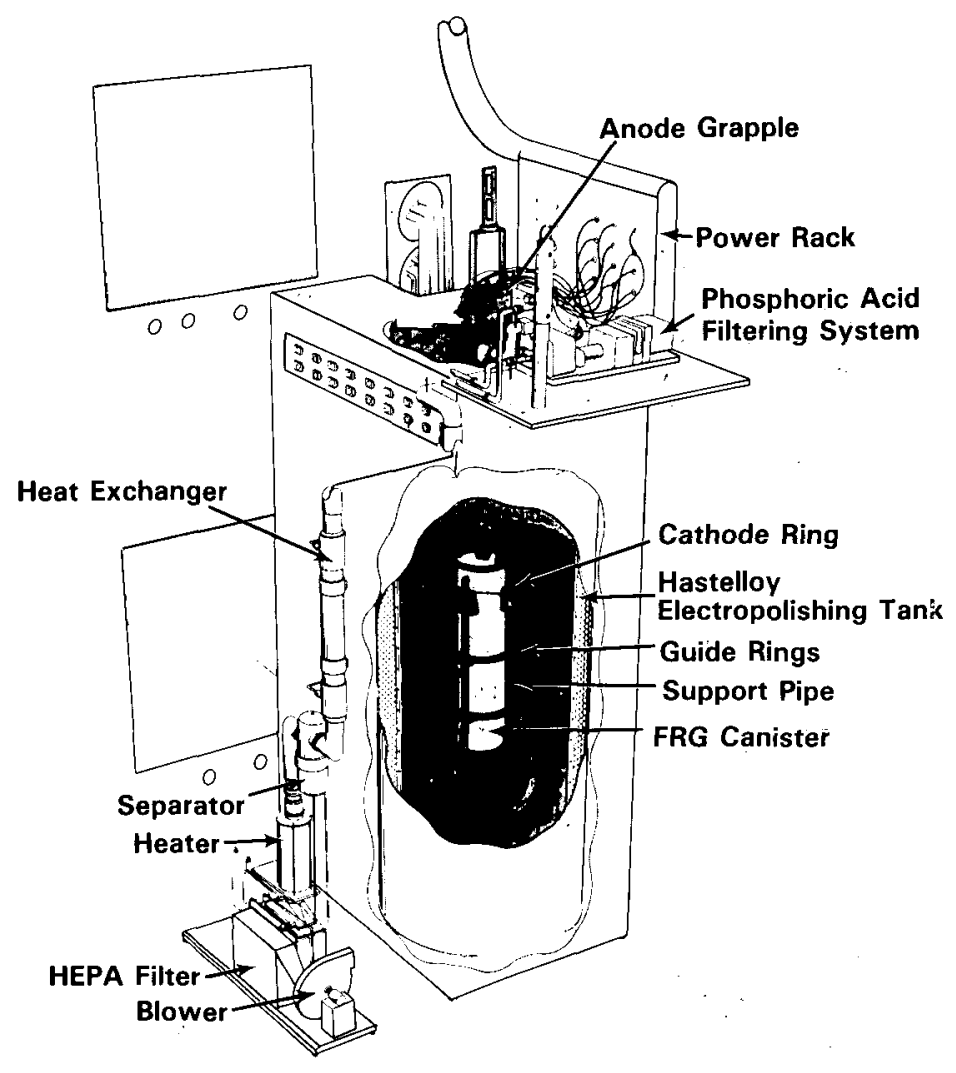

FIGURE 2.12. Canister Electropolishing System

In electropolishing the FRG canisters, the first A-Cell operation was to retrieve the canister from the $A-C e l l$ door transfer cradle and place it in the electropolisher.

First the canister lid was electropolished at a power setting of $1000 \mathrm{~A}$ for $10 \mathrm{~min}$. The electrical contact to the canister was through the lower electrode, on which the canister sat. The canister lid was in the center of the cathode ring at this time.

Next the bottom of the canister was electropolished. First the anode grapple was connected to the canister, which was sitting on the lower electrode of the cathode cage. The canister was then raised $15 \mathrm{~cm}$ above the lower electrode, and the bottom was electropolished for $10 \mathrm{~min}$ at the 1000-A setting on the power supply. The canister level was determined by reading the calibration on the side of the anode grapple, which directly corresponds to the spacing between the bottom of the canister and the lower electrode. 
The last step in this process was to electropolish the canister walls in two stages: first at a high current density (500-A power supply) and next at a low current density $(100 \mathrm{~A})$. In the first stage the canister was actually decontaminated by removing $\sim 1 \mathrm{mil}(0.25 \mu \mathrm{m})$ of the surface metal. The second stage was an etching mode performed to dull the canister surface and thus enhance its emissivity. Emissivity is a heat transfer property important in the exchange of radiant thermal energy from one surface to another. The specifications for the FRG canisters called for an emissivity of greater than 0.4 to provide for adequate heat transfer in the canister shipping cask. The etching achieved this. The canister wall was electropolished by sequentially raising and lowering the canister through the cathode ring. The anode grapple completed the anodic circuit to the canister, and the counter electrode was the ring in the cathode cage. The cathode ring is $15 \mathrm{~cm}$ in height; therefore, the canister had to be raised or lowered in $15-\mathrm{cm}$ increments to electropolish the canister wall.

In the first of the two stages the canister wall was electropolished in two passes. In the first pass the canister was sequentially raised through the cathode ring in $15-\mathrm{cm}$ increments. At each incremental position the electropolisher was operated for 5 min at a power supply setting of $500 \mathrm{~A}$. In the second pass, at the same power setting and time, the canister was lowered back through the cathode ring. However, the canister was first lowered $7.5 \mathrm{~cm}$ to offset each incremental position by $7.5 \mathrm{~cm}$ as it was passed back through the cathode ring. This resulted in a more uniform finish on the final surface.

To etch the canister walls (the final step), the canister was lowered incrementally through the cathode ring as was done in the second pass of stage one. Only one pass through the cathode was required; the power supply setting was $100 \mathrm{~A}$ and the etching time 15 min at each incremental position. Before the canister was removed from the electropolishing tank, the lid was electropolished for $1 \mathrm{~min}$ at $500 \mathrm{~A}$ to remove any acid residue that may have adhered to it.

The canister was then raised (Figure 2.13.) from the cathode cage through an air/water spray originating from the spray ring in the upper portion of 


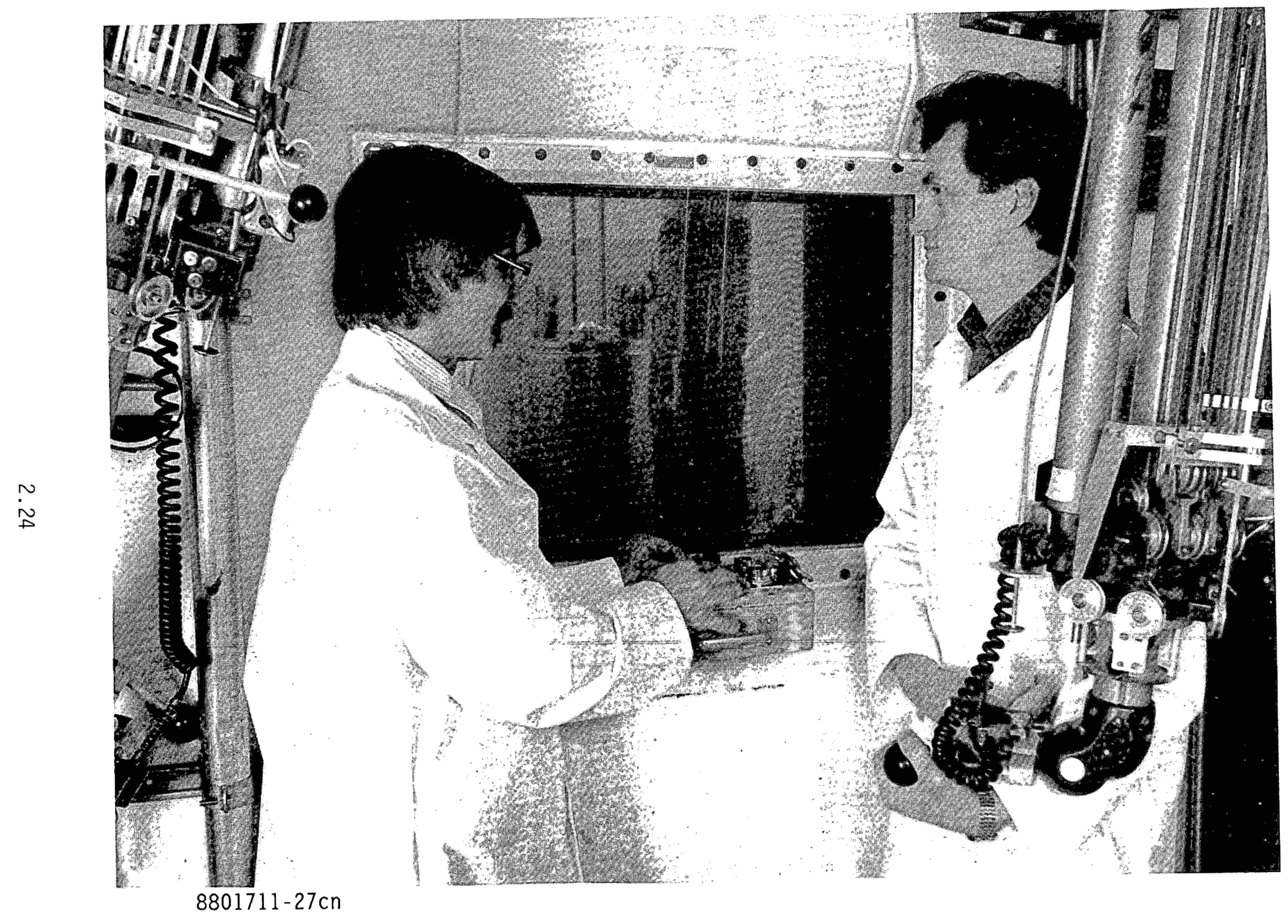

FIGURE 2.13. Retrieval of Canister from Electropolisher 
the electropolishing tank. To provide adequate time for rinsing the canister, the crane was operated at low speed while raising it through the spray ring. The canister was then transported to the rinse/soak tank and lowered to the bottom. The bottom of the canister was then rinsed using the spray nozzle on the floor of the rinse/soak tank. The final rinse was then completed by slowly raising the canister through the spray ring of the rinse/ soak tank.

After rinsing, the canister was allowed to dry and a smear test was conducted using a special smear pad holder, held with a manipulator and moved a fixed distance along the canister side. The smear pad was held by doublesided tape in a preformed holder. Refractory felt was used as the smear pad because of its resistance to the high temperature of the canister side wall. The smear pad ( $5 \mathrm{~cm}$ dia) was moved $30.5 \mathrm{~cm}$ along the axis of the canister, as monitored by a gauge. The total smeared area was $175 \mathrm{~cm}^{2}$.

Gamma activity on the smear pads from ${ }^{137}$ Cs decay products was counted with a GeLi detector in a shielded cave. The beta activity from ${ }^{90} \mathrm{Sr}$ was counted using a mini-scaler and external detector apparatus. The beta activity was counted on air sample filters $5 \mathrm{~cm}$ in diameter. The sample holder positions of the smear pad were very close to the detector in order to capture the short-range beta particles. Alpha activity was determined with a ZnS scintillation detector designed for counting samples shaped like the smear pads.

\subsubsection{Electropolishing Results}

The electropolishing system operated very well for the period during which the 30 FRG canisters were decontaminated. The canisters received in A-Cell were highly oxidized with high levels of smearable contamination on the surface. Figure 2.14 shows a typical canister before and after electropolishing. Electropolishing removed all oxide coating the canister surface and decreased the levels of smearable contamination to levels averaging $300 \mathrm{dpm}$ per $100 \mathrm{~cm}^{2}$ units $\left(5 \mathrm{~Bq} / 100 \mathrm{~cm}^{2}\right)$.

The canisters were determined to contain smearable surface contamination in the range of $1 \mathrm{mrem}$ to $60 \mathrm{mrem}$ per $100 \mathrm{~cm}^{2}$. The decontamination factor (DF) for the process was in the range of $10^{3}$ to $10^{5}$. The smearable 

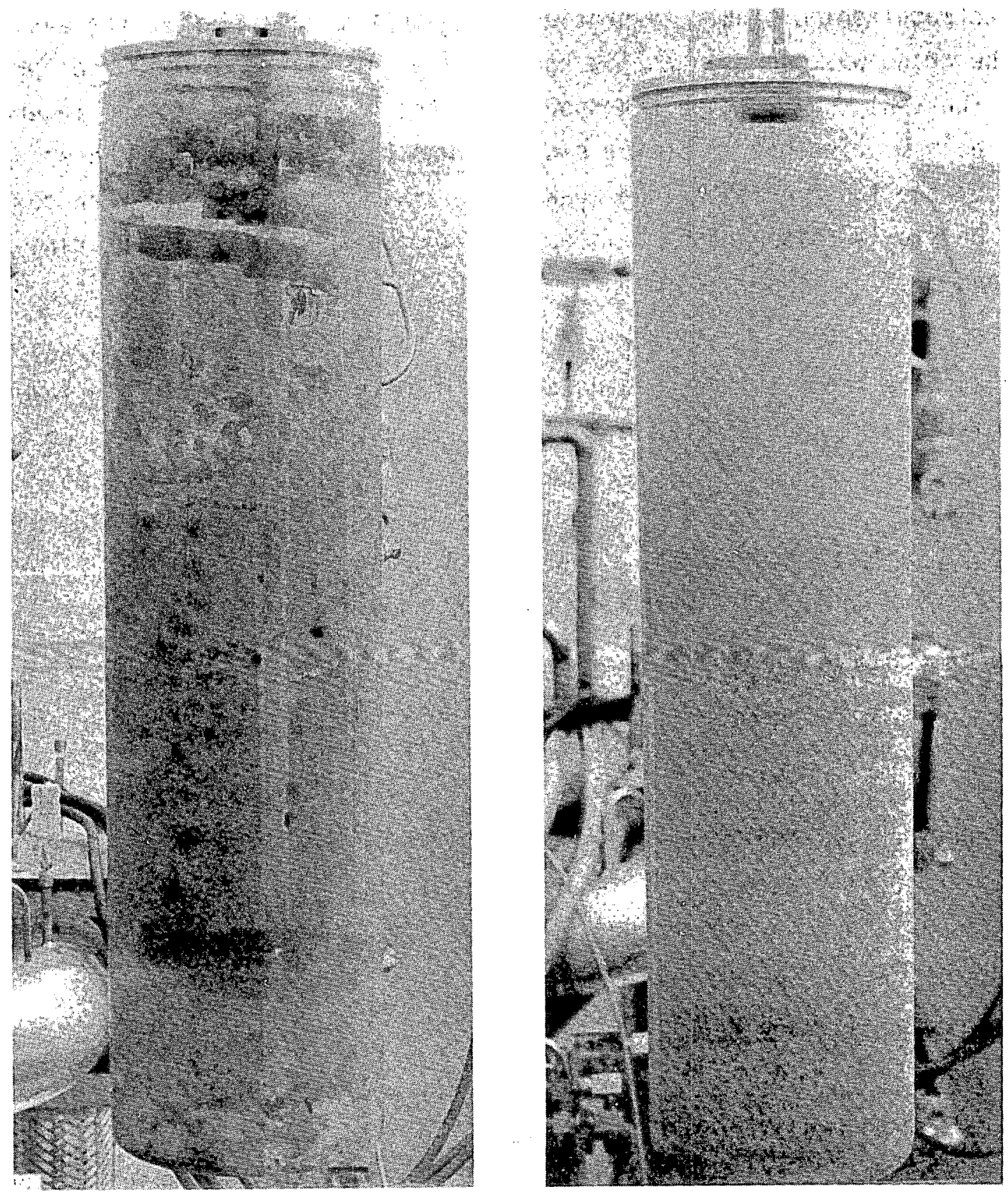

$8801760-1 \mathrm{cn}$ and $-2 \mathrm{cn}$

FIGURE 2.14. Radioactive Canister Before and After Electropolishing 
contamination levels on the decontaminated canisters ranged from 0 to $2000 \mathrm{dpm}$ per $100 \mathrm{~cm}^{2}$ ( 0 to $33 \mathrm{~Bq} / 100 \mathrm{~cm}^{2}$ ) for beta and gamma radiation. The decontamination requirement for the canisters was to reduce the smearable surface contamination to at least $22,000 \mathrm{dpm}$ per $100 \mathrm{~cm}^{2}\left(370 \mathrm{~Bq} / 100 \mathrm{~cm}^{2}\right)$ beta-gamma radiation and $2200 \mathrm{dpm}$ per $100 \mathrm{~cm}^{2}\left(37 \mathrm{~Bq} / 100 \mathrm{~cm}^{2}\right)$ alpha radiation. The actual results of the process surpassed this requirement by a factor of 100 .

The electropolishing process removed $\sim 1 \mathrm{~kg}$ of metal and oxide from the surface of each canister, as measured by weighing the canister before and after electropolishing. The level of chemical species as well as radiochemical species was monitored throughout operation of the electropolisher. Table 2.1 presents the concentration of the various constituents detected in the electrolyte solution.

The total metals concentration in the acid after the 30 canisters were electropolished was $0.8 \mathrm{wt} \%$. Previous electropolishing experience has shown that an electrolyte is useful up to metal concentrations of $10 \mathrm{wt} \%$ metals. Experience gained in electropolishing the FRG canisters shows that a total of

TABLE 2.1. Concentration of Constituents in Electrolyte Solution

\begin{tabular}{|c|c|c|c|c|c|}
\hline Sample \# & $\begin{array}{l}\text { Number of } \\
\text { Canisters } \\
\text { Processed }\end{array}$ & $\begin{array}{l}\mathrm{Fe}, \\
\mathrm{ppm}\end{array}$ & $\begin{array}{l}\mathrm{Ni}, \\
\mathrm{ppm}\end{array}$ & $\begin{array}{l}\mathrm{Cr}, \\
\mathrm{ppm}\end{array}$ & ${ }^{137} \mathrm{Cs}, \mathrm{Ci} / \mathrm{L}$ \\
\hline 1 & 1 & 647 & 1280 & 365 & -- \\
\hline 2 & 5 & 703 & 1685 & 455 & -- \\
\hline 3 & 9 & 945 & 3057 & 790 & $1.86 \times 10^{-6}$ \\
\hline 4 & 18 & 2138 & 2908 & 1062 & $5.95 \times 10^{-6}$ \\
\hline 5 & 22 & 3475 & 3137 & 1405 & $1.05 \times 10^{-5}$ \\
\hline 6 & 25 & 4173 & 3603 & 1695 & $1.20 \times 10^{-5}$ \\
\hline 7 & 27 & 4502 & 4328 & 1933 & $1.29 \times 10^{-5}$ \\
\hline 8 & 30 & 4373 & 4503 & 1932 & $1.35 \times 10^{-5}$ \\
\hline 9 & 32 & 5700 & 4543 & 2229 & $2.10 \times 10^{-5}$ \\
\hline 10 & $33^{(a)}$ & 6627 & 3568 & 2221 & $5.72 \times 10^{-5}$ \\
\hline
\end{tabular}

(a) Three canisters were processed prior to electropolishing the FRG canisters. 
375 canisters could be decontaminated, based on the accumulation of metal in the acid. After electropolishing 30 canisters, there was a total of $3 \times 10^{-2} \mathrm{Ci}{ }^{137} \mathrm{Cs}$ in the $2200 \mathrm{~L}$ of phosphoric acid. This value equates to $-1 \times 10^{-3} \mathrm{Ci}{ }^{137} \mathrm{Cs}$ from each canister.

The general appearance of the electropolished canister surfaces could be characterized as an even "matte" or dull finish although the finish varied somewhat from canister to canister. It was not determined why some canister surfaces were not dulled to the same degree as others. Generally, however, the seven canisters that were pre-electropolished appeared less dull than the others. A11 30 canisters appeared much like the one on which emissivity measurements were obtained. It was measured at greater than 0.4.

The top and bottom of the canisters appeared to have all oxides removed. A smear of the canister bottom was obtained to assess the smearable contamination level after electropolishing. This surface smeared well below the specifications for the $F R G$ canisters.

Al1 30 FRG canisters were placed in a water-cooled storage vessel on completion of electropolishing operations. The water-cooled storage rack consists of an elliptical vessel with an array of 10 vertical tubes in which the canisters are stacked three high. Water is circulated past the array of tubes to dissipate the decay heat of the canisters. After all 30 canisters were $\mathrm{placed}$ in the storage rack, the flow rate of the cooling water was adjusted to $20 \mathrm{~L} / \mathrm{min}$. At this flow rate the inlet and outlet temperatures were 15 and $42^{\circ} \mathrm{C}$, respectively. The cooling water removes $-38 \mathrm{~kW}$ of decay heat from the storage rack. The total decay heat generated from the 30 canisters is $\sim 47 \mathrm{~kW}$. This indicates that $20 \%$ of the decay heat is lost to the cell air through convection from the surface of the electropolishing tank.

2.7 CANISTER CHARACTERIZATION - R. D. Peters, R. W. Goles, J. E. Surma, J. F. Hutchens, G. N. Buck, S. D. Halstead, and S. J. Morris

Each FRG canister was nondestructively characterized by measuring the surface radiation exposure rate, surface temperature, canister weight, ovality and straightness by passage through a go-no go gauge, gamma spectrum, and smearable surface contamination level. The surface temperature and 
exposure rate were measured before the canisters were electropolished, and the canister weight, ovality, gamma spectrum, and smear test were completed after electropolishing.

\subsubsection{Exposure Rate Measurements}

The decay of ${ }^{137} \mathrm{Cs}$ in the glass generates a gamma flux at the surface of the canisters. This flux was measured in terms of Roentgens per unit time $(R / h r)$. The following sections describe the equipment used and the methods for handling data to determine exposure rates.

\subsubsection{Equipment Description}

The equipment for measuring the canister exposure rate consists of ion chamber probes, power supplies, electrometers for measuring passage of current, thermocouples for the probes, and a holder for the probes in the remote ce11. Figure 2.15 gives a schematic of the system.

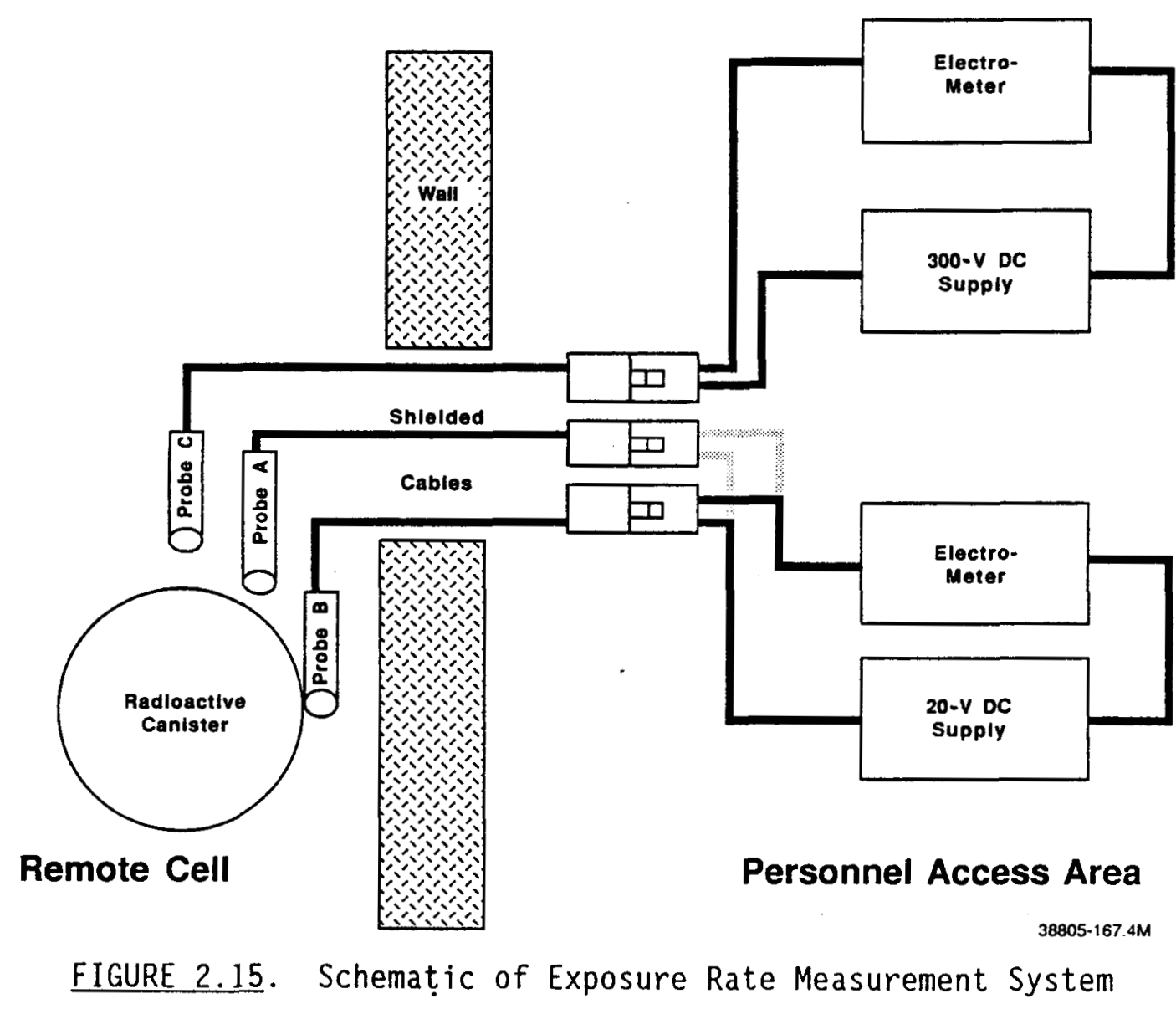


Three probes were used: two are designed for use in a reactor core and are manufactured by Reuter-Stokes, and the other is for medical radiology applications and is manufactured by Exradin. The Reuter-Stokes chambers are $6.4 \mathrm{~mm}$ dia by $76 \mathrm{~mm}$ long, with a $0.033-\mathrm{mm}$-thick steel chamber wall. The Exradin chamber is spherical, has a volume of $3.6 \mathrm{cc}$, and is constructed of plastic. The ion chambers are filled with gas which becomes ionized when subjected to gamma photons. Ionized species migrate to electrodes in the chamber which are polarized by the power supply. The collected ions register as current on a microammeter (or electrometer). This current is converted to exposure rate using calibration data.

The Reuter-Stokes probes were alternately connected to the same direct current power supply and electrometer during measurements. The Exradin probe had an independent power supply (a 300-V dry-cell battery) and electrometer. Probe chambers were positioned at fixed distances from the FRG canisters using an adjustable holder attached to the helium detection vessel. Also, one of the core chambers was held against canisters with a manipulator. Reuter-Stokes chamber temperatures were measured with a thermocouple and displayed on a digital thermometer. During measurements each probe was connected in series with a power supply and electrometer.

\subsubsection{Conversion of Probe Current to Exposure Rate}

Current induced in the ion chamber probe by radiation from FRG canisters can be converted to an exposure rate using calibration data. The following empirical relation is used:

$$
D=\left(y-y^{\prime}-\sigma\right) / \alpha
$$

where $D$ is measured exposure rate, $y$ is measured current in amperes, $y^{\prime}$ is leakage current, and $\alpha$ and $\sigma$ are coefficients. Values of $\alpha, \sigma$, and $y^{\prime}$ for all probes are shown in Table 2.2. The two Reuter-Stokes probes were operated at $20 \mathrm{~V} d c$ and are designated $A$ and $B$. The Exradin probe was operated at $300 \mathrm{~V}$ dc and is designated $C$. Leakage current is the current through the probe/power supply/electrometer circuit in the absence of gamma flux and was measured after the probes were installed in the remote cell. 

TABLE 2.2. Parameters to Convert Cuygent to Exposure
Rate at Room Temperature

\begin{tabular}{rr}
8,700 to & $100,000 \mathrm{to}$ \\
$100,000 \mathrm{R} / \mathrm{hr}$ & $\underline{2,000,000 \mathrm{R} / \mathrm{hr}}$ \\
\hline
\end{tabular}

Probe $A, 20$ volts
$\alpha, A / R / h r$
$5.05 \times 10^{-15}$
$4.72 \times 10^{-15}$
$\left(5.30 \times 10^{-15}\right)$
$\left(5.30 \times 10^{-15}\right)$
$\sigma, A$
$8.36 \times 10^{-12}$
$3.84 \times 10^{-11}$
$\left(4.84 \times 10^{-11}\right)$
$y^{\prime}, A$
$9.00 \times 10^{-11}$
$9.00 \times 10^{-11}$

Probe $B, 20$ volts
$\alpha, A / R / h r$
$5.60 \times 10^{-15}$
$5.19 \times 10^{-15}$
$\left(5.00 \times 10^{-15}\right)$
$\left(5.00 \times 10^{-15}\right)$
$\sigma, A$
$8.39 \times 10^{-12}$
$4.23 \times 10^{-11}$
$\left(2.20 \times 10^{-11}\right)$
$y^{\prime}, A$
$9.00 \times 10^{-11}$
$9.00 \times 10^{-11}$

Probe $C, 300$ volts
$\alpha, A / R / h r$
$4.08 \times 10^{-14}$
$4.08 \times 10^{-14}$
$\sigma, A$
0
0
$y^{\prime}, A$
0
0

(a) Values not in parentheses were obtained by initial calibration using known gamma sources. Values in parentheses have been adjusted to minimize the relative standard error between all measurements. The adjusted values were used to report canister exposure rates, rather than the corresponding initial calibration values.

Values of $\alpha$ and $\sigma$ for probes $A$ and $B$ were based primarily on vendorsupplied calibrations at $8,700 \mathrm{R} / \mathrm{hr}, 100,000 \mathrm{R} / \mathrm{hr}$, and $2,100,000 \mathrm{R} / \mathrm{hr}$. The slightly nonlinear exposure-current response was linearized using different 
sets of $\alpha$ and $\sigma$ for the low range $(8,700 \mathrm{R} / \mathrm{hr}$ to $100,000 \mathrm{R} / \mathrm{hr})$ and the high range $(100,000 \mathrm{R} / \mathrm{hr}$ to $2,100,000 \mathrm{R} / \mathrm{hr})$. Once al1 measurements were made, it was found that probe $A$ readings were consistently higher than probe $B$ readings and that the average relative error for all exposure rates was about $10 \%$. The consistent variation between probes $A$ and $B$ suggested that the vendor-supplied conversion parameters were inaccurate. Values for $\alpha$ and $\sigma$ were then varied by successive trials until a minimum average relative error was found. These adjusted values are shown in parentheses in Table 2.2. The average relative error was reduced from about $10 \%$ to $5 \%$ using the adjusted conversion parameters.

During measurements, probes $A$ and $B$ were usually heated by FRG canisters to about $40^{\circ} \mathrm{C}$ but never exceeded $65^{\circ} \mathrm{C}$. Room-temperature calibration data were used, however, because $\alpha$ and $\sigma$ are insensitive to temperatures below $100^{\circ} \mathrm{C}$.

Probe $\mathrm{C}$ was calibrated at PNL with one exposure rate of $66,000 \mathrm{R} / \mathrm{hr}$ and at room temperature only. The parameter $\sigma$ is indeterminate and is presumed to be zero. The value for $y^{\prime}$ was found to be less than $10^{-13} \mathrm{~A}$, and was also considered to be zero in the calculations. No adjustment of $\alpha$ and $\sigma$ for probe $C$ was needed.

During measurements, current from probes $A$ and $B$ generally ranged from $0.2 \times 10^{-9}$ to $1.5 \times 10^{-9} \mathrm{~A}$. For probe $C$, the current was higher because of greater sensitivity and was in the range of $0.8 \times 10^{-9}$ to $10 \times 10^{-9} \mathrm{~A}$.

\subsubsection{Distance Correction}

Probes were located some finite distance $X$ from the canister surface. It is necessary to correct measurements made at a distance to a surface exposure rate. Based on analys is of the results from the computer code ISOSHLD, the following relation is found to describe the dependence of exposure rate versus distance from $F R G$ canisters for distances less than about $15 \mathrm{~cm}$ :

$$
D=\frac{D_{0}}{1+h X}
$$


where $D_{0}$ is surface exposure $(R / h r), h$ is a coefficient with a value of $0.095 \mathrm{~cm}^{-1}$, and $X$ is distance between the center line of the probe and the surface of the canister. The radius of all three probes is about $3.2 \mathrm{~mm}$. The value for $X$ is given by the distance between the outside of the probe and the canister plus the radius of $3.2 \mathrm{~mm}$. The distance from the probe wall to the canister varied from $0 \mathrm{~cm}$ (probe held against canister) to $16.2 \mathrm{~cm}$. Most measurements were done with one probe against the canister (probe $B$ ), one at $1.5 \mathrm{~cm}$ from the canister (probe $A$ ), and one at $2.5 \mathrm{~cm}$ from the canister (probe $C$ ). To determine $D_{0}$, Equation (2) is rearranged:

$$
D_{0}=(1+h X) D \text {. }
$$

\subsubsection{Exposure Rate Results}

The results from measuring the 30 canisters containing ${ }^{137} \mathrm{Cs}$ and ${ }^{90} \mathrm{Sr}$ isotopes are given in Table 2.3. The reported exposure rate is generally an average of three probe measurements that have been extrapolated to a surface exposure using Equation (3). The range of exposure rates is $26,000 \mathrm{R} / \mathrm{hr}$ (canister 44) to $320,000 \mathrm{R} / \mathrm{hr}$ (canister 48). The standard deviation is calculated using the variance and t-values from the "Student" distribution (Perry and Chilton 1973). All but eight canisters have surface exposure rates in the range of 218,000 to $320,000 \mathrm{R} / \mathrm{hr}$.

\subsubsection{Temperature Scan}

The axial surface temperature profile of each canister was taken while the canister was in the air lock prior to leak checking. The temperature was taken at five equidistant points along each canister using the canister surface temperature probe (Figure 2.16) and the temperature probe alignment

guide. The temperature probe consists of an Omega surface thermocouple having a flexible stainless steel tip so that little pressure is needed to ensure good contact with the canister. A temperature probe alignment guide was made to hang above the canister, with five pieces of angle steel serving as resting points for the temperature probe. The alignment guide was 
TABLE 2.3. Measured Radiation Exposure Rates at Surface of FRG Canisters

\begin{tabular}{|c|c|c|}
\hline $\begin{array}{l}\text { Canister } \\
\text { Number }\end{array}$ & $\begin{array}{c}\text { Mean Surface } \\
\text { Exposure } \\
\mathrm{R} / \mathrm{hr} \times 10^{3} \\
\end{array}$ & $\begin{array}{c}\text { Standard Deviation, } \\
95 \% \text { Confidence Limit, } \\
\mathrm{R} / \mathrm{hr} \\
\end{array}$ \\
\hline $\begin{array}{r}1 \\
2 \\
3 \\
5 \\
6 \\
7 \\
8 \\
10 \\
12 \\
14 \\
17 \\
18 \\
20 \\
21 \\
28 \\
33 \\
34 \\
36 \\
37 \\
38 \\
41 \\
42 \\
43 \\
44 \\
45 \\
46 \\
47 \\
48 \\
49 \\
50\end{array}$ & $\begin{array}{r}236 \\
266 \\
233 \\
273 \\
293 \\
284 \\
282 \\
275 \\
235 \\
262 \\
238 \\
284 \\
269 \\
255 \\
219 \\
95 \\
172 \\
106 \\
79 \\
277 \\
58 \\
44 \\
33 \\
26 \\
320 \\
286 \\
290 \\
313 \\
283 \\
287\end{array}$ & $\begin{array}{r}22.7 \\
-- \\
15.6 \\
8.8 \\
38.6 \\
19.4 \\
17.6 \\
19.3 \\
36.9 \\
8.4 \\
19.9 \\
18.7 \\
12.7 \\
19.4 \\
19.9 \\
14.8 \\
18.5 \\
6.6 \\
7.8 \\
49.1 \\
1.1 \\
1.6 \\
5.4 \\
0.3 \\
-. \\
34.2 \\
65.2 \\
32.3 \\
40.4 \\
12.4\end{array}$ \\
\hline
\end{tabular}

designed so that the upper position corresponds to the top surface of the glass in the canister and the lower four positions are below the glass surface.

The canisters sat in the air lock at least $2 \mathrm{hr}$ before the temperature scan was conducted to let them reach thermal steady state. In addition to the five measurements obtained using the temperature probe alignment guide, the lid temperature was taken. The temperature of the bottom flange was 


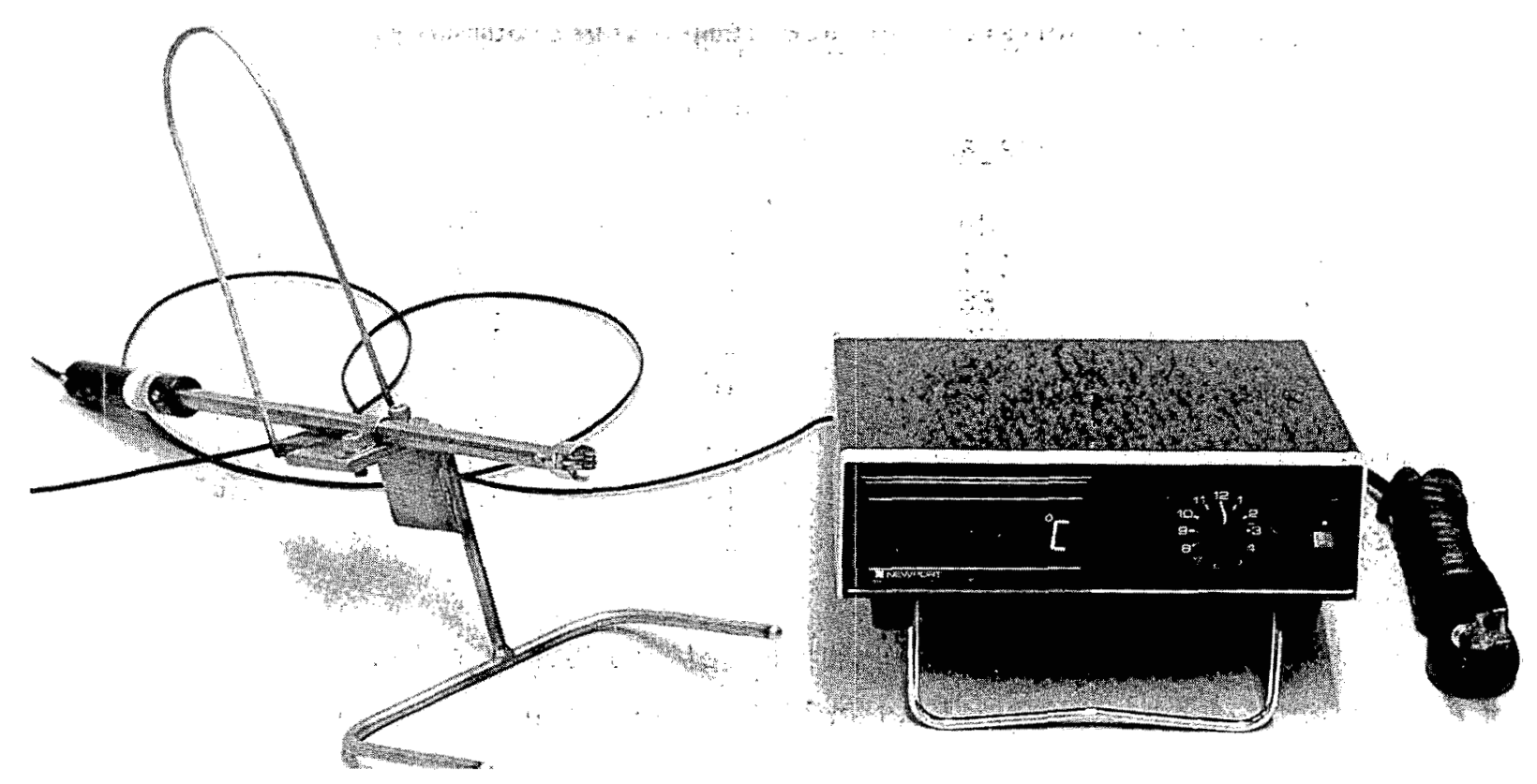

$8707264-6 \mathrm{cn}$

FIGURE 2.16. Temperature Probe Equipment System

recorded for the last eight canisters. Table 2.4 summarizes the data: the average temperature, standard deviation, and minimum and maximum values are given for the seven temperatures recorded for each canister as well as the average of the four lower positions on the canister $(36,56,76$ and $96 \mathrm{~cm}$ ) and the maximum variation of each canister (maximum temperature minus minimum temperature). The average of the lower four temperatures was $171^{\circ} \mathrm{C}$, and the average lid temperature was $89^{\circ} \mathrm{C}$ for the 30 canisters. The maximum average temperature for a canister was $205^{\circ} \mathrm{C}$, and the minimum average temperature was $133^{\circ} \mathrm{C}$. The average maximum temperature difference was $57^{\circ} \mathrm{C}$.

The canister surface temperatures were also analyzed for the individual RLFCM campaigns. The average of the lower four canister surface temperatures was $171^{\circ} \mathrm{C}$ with a standard deviation of $16^{\circ} \mathrm{C}$ for RLFCM- $7 ; 159^{\circ} \mathrm{C}$ with a standard deviation of $18^{\circ} \mathrm{C}$ for RLFCM-8; and $181^{\circ} \mathrm{C}$ with a standard deviation of $12^{\circ} \mathrm{C}$ for RLFCM- 9 .

\subsubsection{Canister Weight Measurement}

The canister weighing system was. used to weigh each canister after it was electropolished and rinsed. The weighing system consisted of a Dillon 
TABLE 2.4 Canister Surface Temperature Summary, ${ }^{\circ} \mathrm{C}$

Distance from Top of Canister, cm

Lid

15

36

56

76

96

Lower Flange

Avg. of Lower Four

Max.-Min.
Standard

Average Deviation

89
121
166
172
176
168
144
171
57

11

16

19

20

18

18

22

18

12

\begin{tabular}{ccc} 
Minimum & & Maximum \\
\cline { 1 - 1 } 70 & & 118 \\
87 & & 155 \\
128 & & 201 \\
132 & & 207 \\
135 & 208 \\
123 & 204 \\
105 & 174 \\
133 & 205 \\
28 & & 79
\end{tabular}

Model $Z$ load ce11, lifting bail, Dillon Model SG1000P digital readout, and $15 \mathrm{~m}$ of connecting cable. The load cell was connected in series with the 2.4-m lifting yoke before a canister was removed from the rinse/soak tank. The weight of the canister was then recorded after the canister was allowed to dry.

The amount of metal removed during electropolishing, $1.1 \mathrm{~kg}$, was determined by weighing a canister before and after electropolishing. The weight of glass in each canister was calculated by subtracting the total empty canister weight and the weight of metal removed during electropolishing from the full canister weight. The volume of glass in each canister was calculated based on void space measurements taken prior to welding. The glass specific gravity was calculated by dividing the glass weight by the glass volume for each canister. Table 2.5 summarizes the canister weight data, reporting the average weight, standard deviation, maximum weight, and minimum weight, as well as the glass volume and specific gravity, for the 30 canisters.

\subsubsection{Canister Straightness and Ovality Test}

One of the quality assurance criteria required by the FRG was that the canisters pass a go-no go test for ovality and straightness. This was necessary so that the canisters will fit in the tubes of the Asse Mine in Germany. The FRG supplied one small tube (306 mm inside diameter) and one large tube (310 $\mathrm{mm}$ inside diameter) that the canisters were required to fit through. In 
TABLE 2.5. Summary of Canister Weight Data

\begin{tabular}{|c|c|c|c|c|}
\hline & Average & $\begin{array}{l}\text { Standard } \\
\text { Deviation }\end{array}$ & Minimum & Maximum \\
\hline $\begin{array}{l}\text { Canister Weight, } \mathrm{kg} \\
\text { Lid Weight, kg } \\
\text { Fiberfrax Weight, } \mathrm{kg} \\
\text { Helium Capsule Weight, } \mathrm{kg} \\
\text { Total Empty Canister Weight, } \mathrm{kg} \\
\text { Weight Removed in EPT, } \mathrm{kg} \\
\text { Ful1 Canister Weight, kg } \\
\text { Glass Weight, kg }\end{array}$ & $\begin{array}{r}73.4 \\
5.2 \\
0.5 \\
0.7 \\
79.8 \\
1.1 \\
237 \\
158.3\end{array}$ & $\begin{array}{l}1.1 \\
0.0 \\
0.0 \\
0.0 \\
1.1 \\
0.0 \\
6.0 \\
5.9\end{array}$ & $\begin{array}{r}71.4 \\
5.1 \\
0.5 \\
0.7 \\
77.8 \\
1.1 \\
222 \\
143.6\end{array}$ & $\begin{array}{r}76.4 \\
5.2 \\
0.5 \\
0.7 \\
82.8 \\
1.1 \\
249 \\
171.4\end{array}$ \\
\hline $\begin{array}{l}\text { Glass Volume, liters } \\
\text { Glass Specific Gravity }\end{array}$ & $\begin{array}{r}60.6 \\
2.61\end{array}$ & $\begin{array}{l}1.6 \\
0.10\end{array}$ & $\begin{array}{l}58.6 \\
2.32\end{array}$ & $\begin{array}{r}64.2 \\
2.81\end{array}$ \\
\hline
\end{tabular}

the event that a canister failed to pass through the small tube, the larger one would be used to determine whether the canister was acceptable.

The ovality and straightness test consisted of lowering the canister into the tube, which was mounted on the side of the electropolisher rack in A-Cel1. The canister was then rotated $180^{\circ}$ and raised back out of the tube. A11 30 canisters passed through the smaller tube without difficulty; thus the larger tube was not needed during the A-Cell operations.

\subsubsection{Gamma Scan}

The FRG canisters were gamma scanned to determine the homogeneity of ${ }^{137} \mathrm{Cs}$ in the canister glass. (The canisters also contain ${ }^{90} \mathrm{Sr}$, but this isotope is difficult to measure since no significant $\gamma$ activity is associated with its decay.)

Canisters were gamma scanned in the decontamination cell using a GeLi detector which monitored gamma emissions through a field-of-view restricting collimator. The system depicted in Figure 2.17 was used to draw the canister up out of the canister ovality gauge with the A-Cell crane. The ovality gauge was used to position the canister at a fixed distance from the GeLi detector. As each canister was lifted past the collimator at a fixed rate, two gamma scans were obtained at $180^{\circ}$ from each other. The second scan was used as a further check of glass homogeneity. 

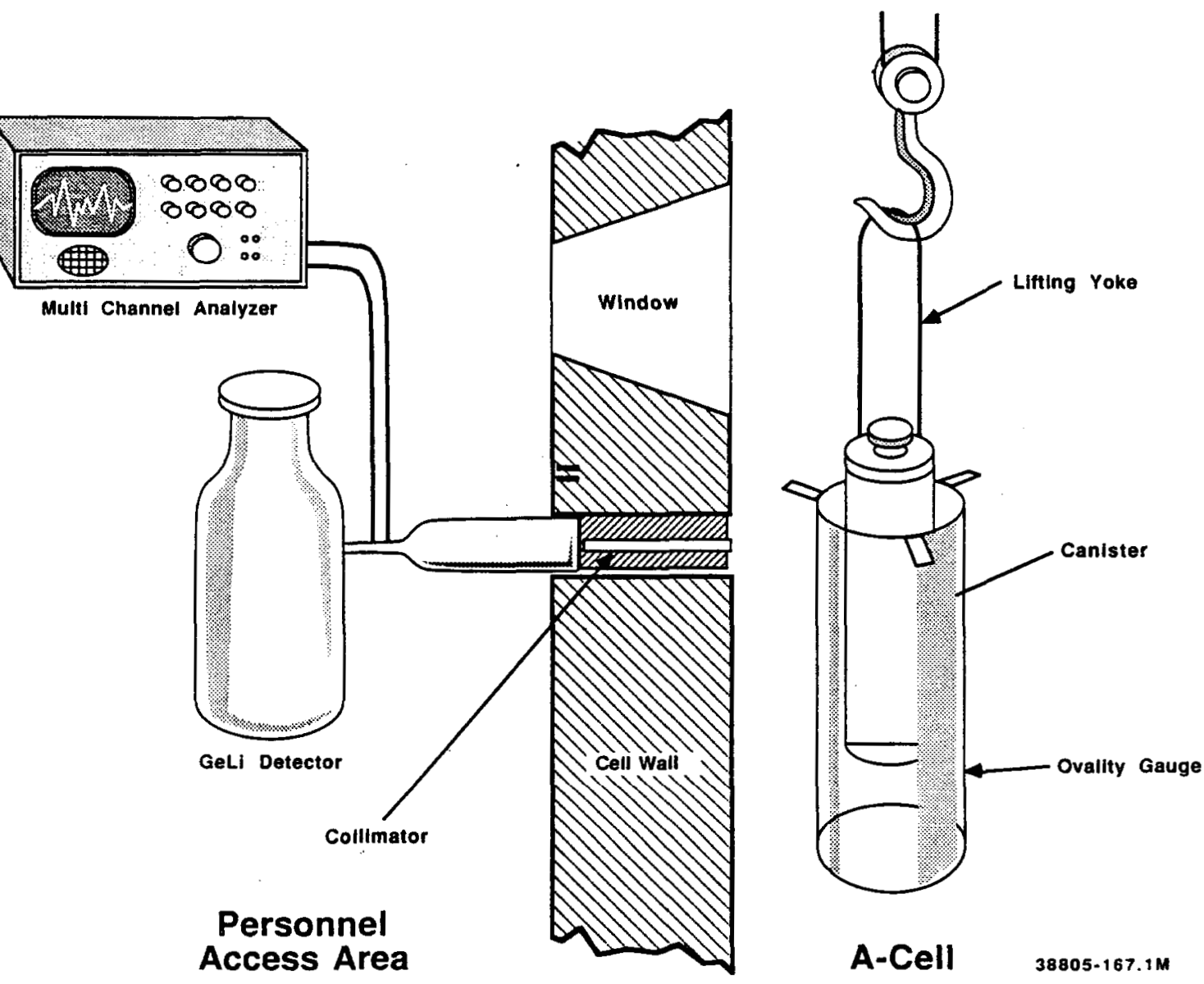

\section{FIGURE 2.17. Gamma Scan System}

Gamma scanning did not provide absolute $\gamma$-detection; however, the gamma system's sensitivity was invariant throughout each scan. Therefore, all canister-scan data were collected under similar conditions so that canister results are all comparable.

The three sets of canisters produced contained different levels of ${ }^{137} \mathrm{CS}$ within the glass. The specifications for the first and third sets of ten canisters called for an equal cesium content in each canister. If the glass was homogeneous in ${ }^{137} \mathrm{Cs}$, the gamma scan would reveal this. Figure 2.18 shows a gamma scan typical of either the first or third set of canisters. The second set of canisters contained varied amounts of cesium; the cesium concentration in the glass of the first canisters was the same as that of the 


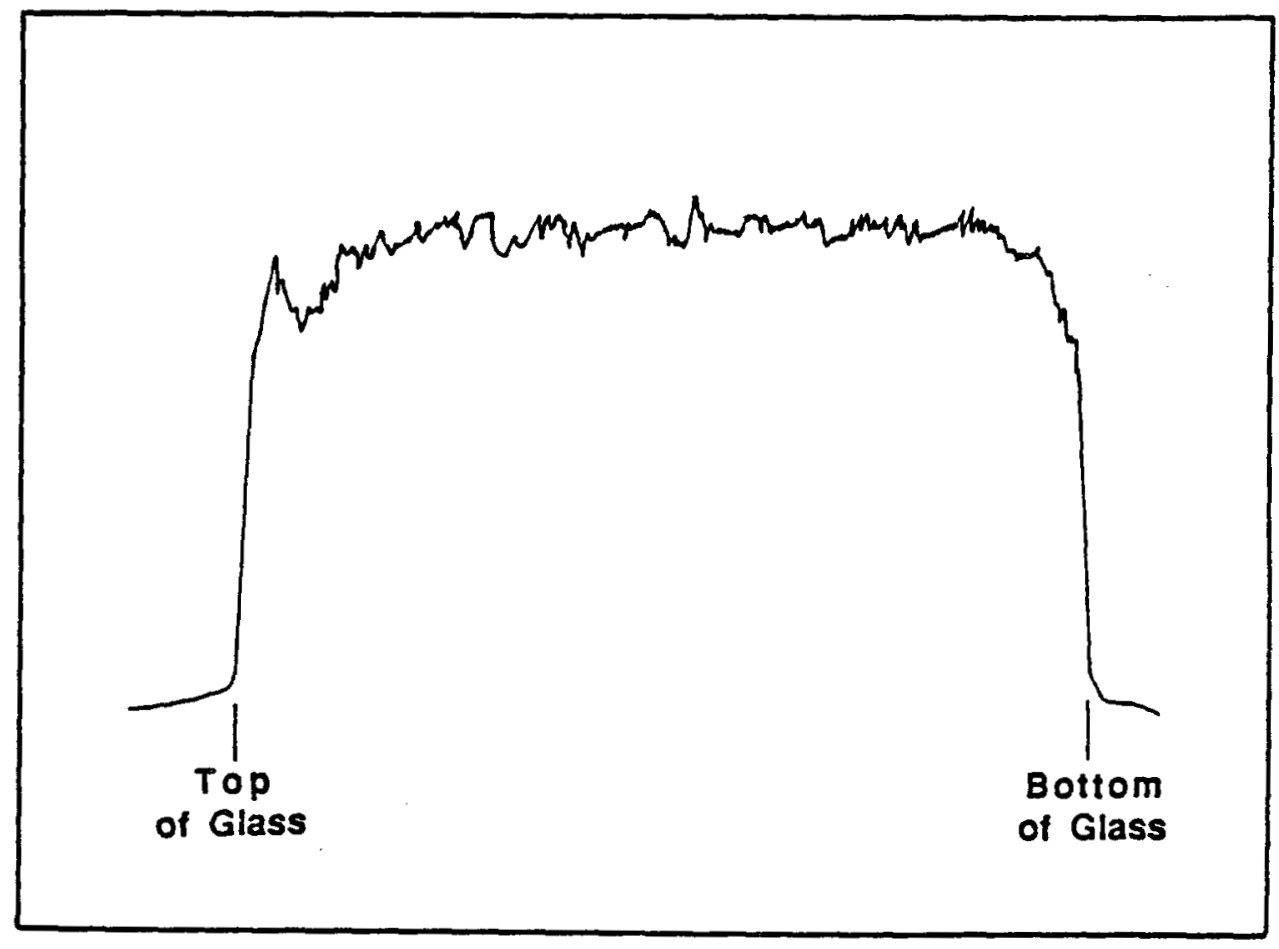

$38806-159.2$

FIGURE 2.18. Gamma Scan of Normal Canister

first set of ten canisters, but gradually decreased throughout production. Figure 2.19 is a typical scan from this second set of ten canisters.

A void within the glass was detected for only one canister (no. 33) and was confirmed by weight measurement. Figure 2.20 shows the gamma scan, with the area labeled where a void is suspected. There were two glass pours into the canister, one with a higher cesium concentration than the other. If no void were present, the scan for the first pour would not have the lower step labeled void on the figure. This scan indicated that the void area is $-15 \mathrm{~cm}$ long and, since there was a fairly strong gamma emission, it probably contains thin strands of hairlike glass rather than being completely void.

One further measurement was performed on selected canisters to determine the distribution of gamma energy emitted from the canisters. This measurement was obtained by positioning a stationary canister opposite the collimator and detector and using the multichannel analyzer. A scan from 0 to 


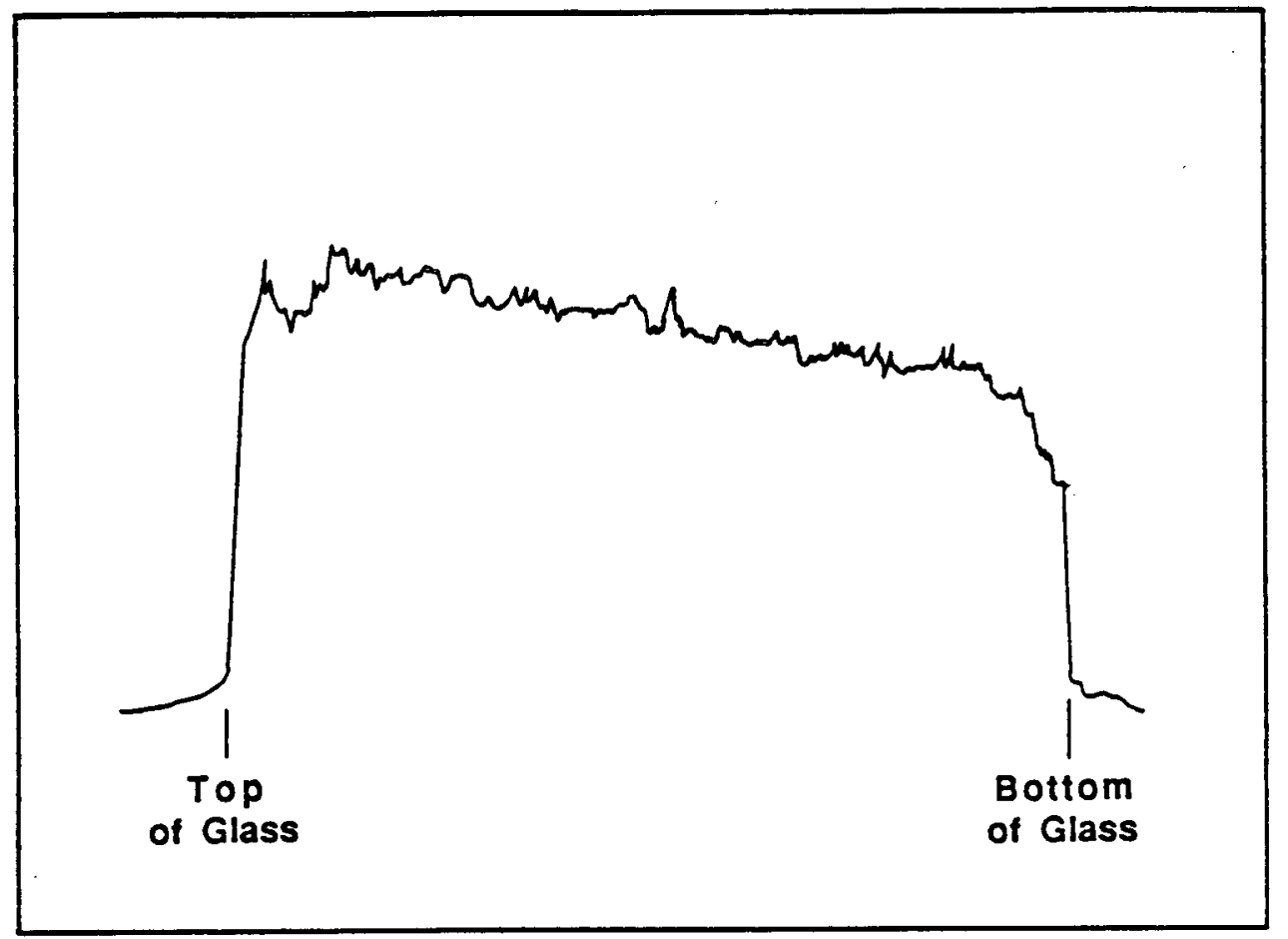

$38806-159.4$

FIGURE 2.19. Typical Gamma Scan of RLFCM-8 Canister

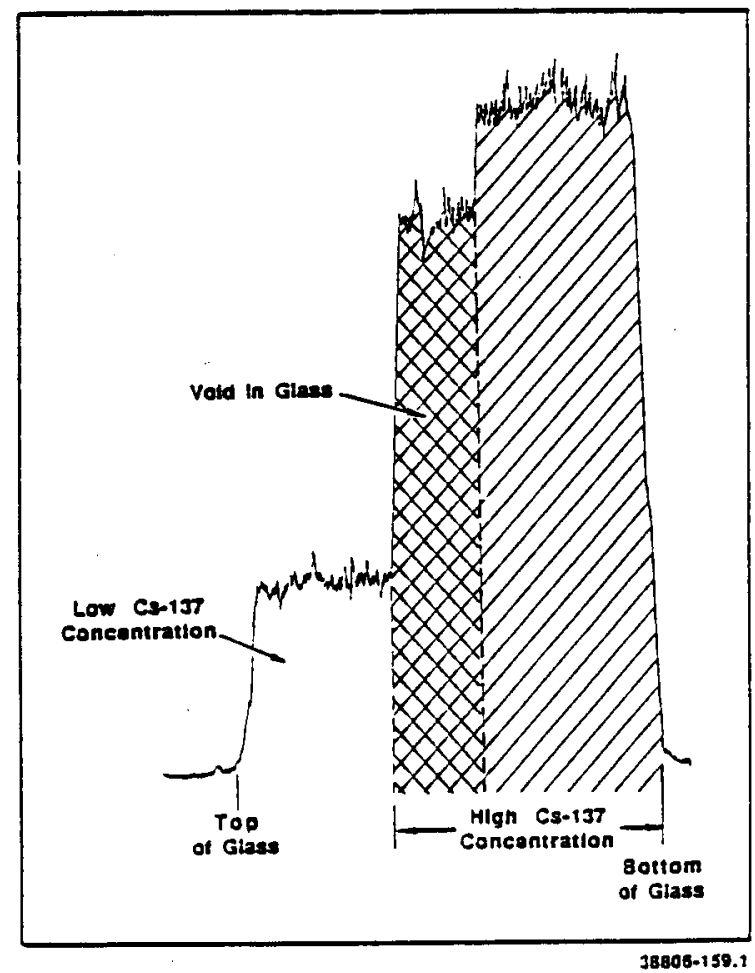

FIGURE 2.20. Gamma Scan of Canister with Void 
$1,024 \mathrm{MeV}$ was obtained similar to that shown in Figure 2.21. This scan shows that a large portion of the $\gamma$ emissions is in the lower energy area of the scan.

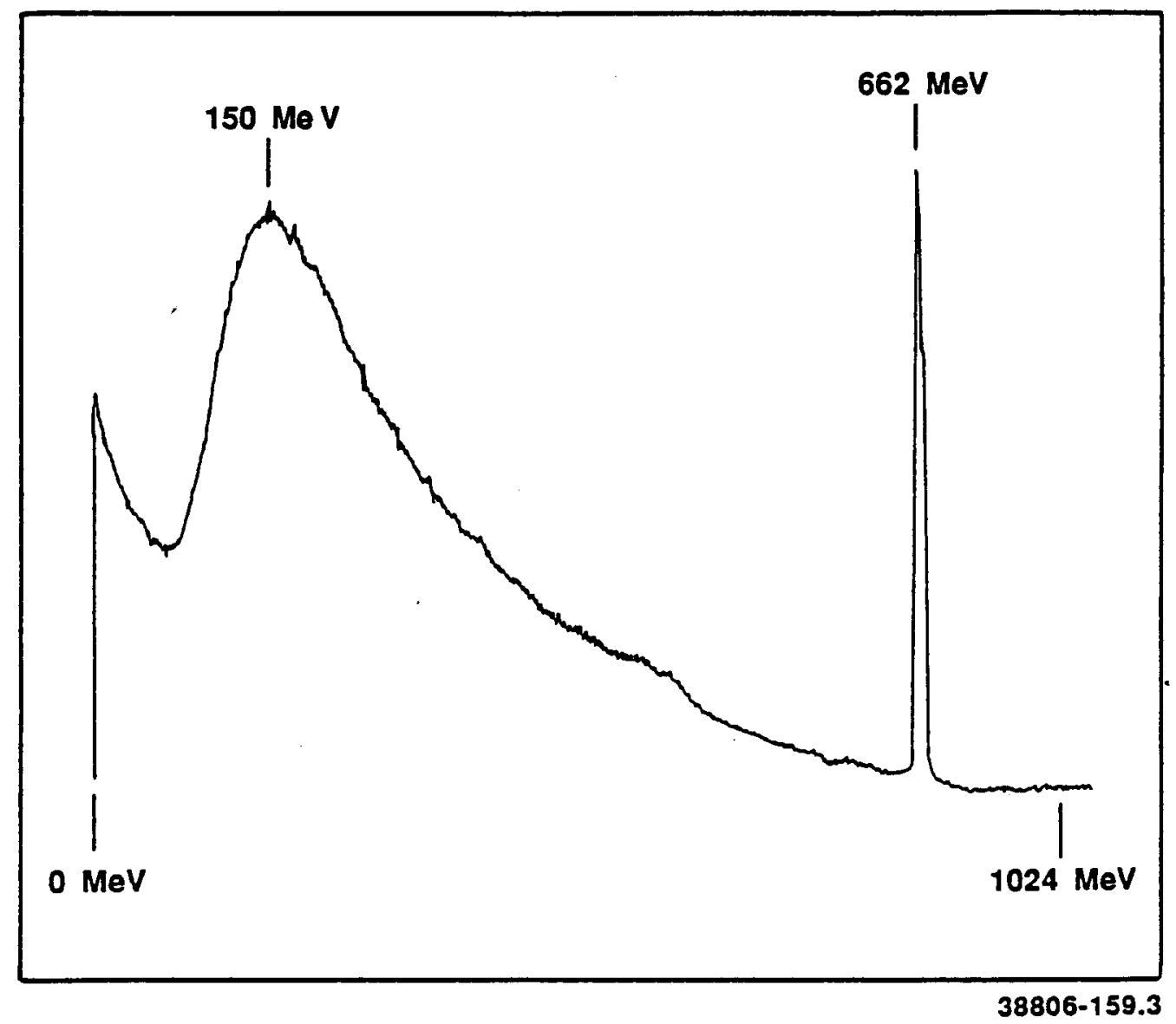

FIGURE 2.21. Gamma Spectrum of RLFCM Glass 


\subsection{REFERENCES}

Brouns, R. A., C. R. Allen, and J. A. Powe11, compilers. 1987. LFCM Vitrification Technology Quarterly Progress Report October-December 1986. PNL-6320-1, Pacific Northwest Laboratory, Richland, Washington.

Brouns, R. A., C. R. Allen, and J. A. Powell, compilers. 1988. LFCM Vitrification Technology Quarterly Progress Report January-March 1987. PNL-6320-2, Pacific Northwest Laboratory, Richland, Washington.

Brouns, R. A., C. R. Allen, and J. A. Powel1, compilers. 1988. LFCM Vitrification Technology Quarterly Progress Report Apri]-June 1987. PNL-6320-3, Pacific Northwest Laboratory, Richland, Washington.

Brouns, R. A., C. R. Allen, and J. A. Powell, compilers. 1988. LFCM Vitrification Technology Quarterly Progress Report July-September 1987. PNL-6320-4, Pacific Northwest Laboratory, Richland, Washington.

Brouns, R. A., and J. A. Powe11, compilers. 1988. Nuclear Waste Treatment Program Annual Report for FY 1987. PNL-6686, Pacific Northwest Laboratory, Richland, Washington.

Burkholder, H. C., and R. A. Brouns, compilers. 1987. Nuclear Waste Treatment Program Annual Report for FY 1986. PNL-6325, Pacific Northwest Laboratory, Richland, Washington.

Burkholder, H. C., and J. M. Rusin, compilers. 1985. Nuclear Waste Treatment Program, Annual Report for FY 1984. PNL-5414, Pacific Northwest Laboratory, Richland, Washington.

Holton, L. K., Jr., et a1. 1989. Processing Summary Report: Fabrication of Cesium and Strontium Heat and Radiation Sources. PNL-6790, Pacific Northwest Laboratory, Richland, Washington.

Perry, R. H., and C. H. Chilton. 1973. Perry's Chemical Engineers' Handbook 5th edition. Chapter 2, "Statistical Analysis." McGraw-Hill, New York. 


\subsection{DOCUMENTATION OF NUCLEAR WASTE TREATMENT PROGRAM TECHNOLOGY}

The documentation of NWTP work was emphasized as a key part of the efficient closeout of the program. The reports and presentations issued in FY 1988 are listed below:

Brouns, R. A., C. R. Allen, and J. A. Powe11, compilers. 1988. LFCM Vitrification Technology Quarterly Progress Report January-March 1987. PNL-6320-2, Pacific Northwest Laboratory, Richland, Washington.

Brouns, R. A., C. R. Allen, and J. A. Powell, compilers. 1988. LFCM Vitrification Technology Quarterly Progress Report April-June 1987. PNL-6320-3, Pacific Northwest Laboratory, Richland, Washington.

Brouns, R. A., C. R. Allen, and J. A. Powe11, compilers. 1988. LFCM Vitrification Technology Quarterly Progress Report July-September 1987. PNL-6320-4, Pacific Northwest Laboratory, Richland, Washington.

Brouns, R. A., and J. A. Powe11, compilers. 1988. Nuclear Waste Treatment Program Annual Report for FY 1987. PNL-6686, Pacific Northwest Laboratory, Richland, Washington.

Bunne11, L. R. 1988. Laboratory Work in Support of West Valley Glass Development. PNL-6539, Pacific Northwest Laboratory, Richland, Washington.

Faletti, D. W., H. Harty, T. A. Erb, and C. A. Lo Presti. 1988. User's Guide for West Valley Feed Preparation Code (RECIPE). PNL-6425, Pacific Northwest Laboratory, Richland, Washington.

Faletti, D. W., and L. J. Ethridge. 1988. "A Method for Predicting Cracking in Waste Glass Canisters." Nuclear and Chemical Waste Management.

Farnsworth, R. K., D. W. Faletti, and M. J. Budden. 1988. Application of TEMPEST Code to Canister Filling Heat Transfer Problem. PNL-6474, Pacific Northwest Laboratory, Richland, Washington.

Holton, L. K., R. D. Dierks, R. W. Goles, and J. E. Surma. 1988. "Operating Experience in a Radioactive Liquid-Fed Ceramic Melter Vitrification Facility." In Waste Management '88, Vol. 2, R. G. Post, Editor, p. 217. University of Arizona, Tucson, Arizona.

Koegler, S. S., and S. J. Mitche11. 1988. Evaluation of Liquid-Fed Ceramic Melter Scale-Up Correlations. PNL-6362, Pacific Northwest Laboratory, Richland, Washington.

Kuhn, W. L., M. R. Toland, and B. A. Pulsipher. 1988. Process Simulation and Statistical Approaches for Validating Waste Form Qual ification Models. PNL-6699, Pacific Northwest Laboratory, Richland, Washington. 
Reimus, M. A., G. B. Mellinger, and G. F. Piepel. 1988. "West Valley Glass Product Qualification Durability Studies: Effects of Composition, Redox State, Heat Treatment, and Groundwater." In Waste Management '88, University of Arizona, Tucson, Arizona.

Ross, W. A., R. A. Brouns, and H. C. Burkholder. 1988. "Treatment Needs for Greater-Than-Class C LLW." Proceedings of Spectrum '88, American Nuclear Society, La Grange Park, IIlinois.

Surma, J. E., L. K. Holton, Jr., Y. B. Katayama, R. F. Klein, and M. L. Elliott. 1988. "Closure, Decontamination and Characterization of Canisters of High-Activity Borosilicate Glass." Proceedings of Spectrum '88, American Nuclear Socjety, La Grange Park, Illinois. 


\subsection{LOW-LEVEL WASTE COORDINATION}

S. C. Slate - Manager

\subsection{OBJECTIVES}

The Low-Level Waste Coordination Task coordinates long-term research and development programs that focus on low-level radioactive wastes. The programs are conducted for the Department of Energy's (DOE) National Low-Leve1 Waste Management Program (NLLWMP) at DOE-Idaho and comprise theoretical and experimental studies on many facets of low-level waste (LLW) management. The three programs conducted during FY 1988 concerned barrier enhancement (Engineered Sorbent Barriers Program), waste-form leaching (Special Waste-Form Lysimeters - Arid Program), and intruder scenarios (Review of Intruder Scenarios Program). The programs are jointly funded by DOE's Office of Nuclear Energy and Office of Defense Programs. Pacific Northwest Laboratory has coordinated the management of these three programs within the Nuclear Waste Treatment Program.

\subsection{SUMMARY}

The major accomplishments of the three FY 1988 Low-Level Waste Coordination programs are discussed below.

The primary focus of the Engineered Sorbent Barriers Program in FY 1988 was the development of a design guide that will allow sorbent barrier technology to be applied to any site. Six steps were identified that must be followed to successfully design an engineered sorbent barrier (ESB). The procedures, factors, and concerns for each step were identified and discussed in the draft design guide, which was submitted to the NLLWMP for review. The design process is summarized in this report. The guide will be completed and published in FY 1989.

Another focus of the Engineered Sorbent Barriers Program in FY 1988 was a study of laboratory batch contact tests involving different sorbent materials. The purpose of the tests was to determine their effectiveness under various conditions. The results indicated that 1) the adsorption of both clinoptilolite and activated carbon does not vary at $\mathrm{pH}$ of 3 and above; 
2) based on the 7 inear adsorption curves for ${ }^{85} \mathrm{Sr},{ }^{60} \mathrm{Co}$, and ${ }^{137} \mathrm{Cs}$, the use of a constant $K_{d}$ is appropriate when estimating sorption; and 3) alternative methods to flow-through column tests are required because of slow adsorption kinetics. The final report on this testing will be published in FY 1989.

The Special Waste Form Lysimeters - Arid Program consisted of two studies in FY 1988. The first study involved geochemical modeling of laboratory experiments to investigate the performance of solidified LLW in a typical arid, near-surface disposal site. Batch leaching, soil adsorption column and soil/waste form column experiments conducted earlier were analyzed with the geochemical model MINTEQ to provide insight into the effects of waste on leachate composition. The second study was conducted at a lysimeter facility, where concrete, polymer and bitumen waste forms were buried in 1983 and have been leached by water from natural precipitation since that time. Data continued to be collected in FY 1988 on the release of radionuclides from each lysimeter. The measurements indicated that the release of tritium continues to be a linear function of the amount of water draining from the lysimeters and that the amounts of ${ }^{60} \mathrm{Co}$ released from the concrete and polymer lysimeters per unit of drainage with continues to increase. Two topical reports were issued during FY 1988.

The focus of the Documentation of Intruder Scenarios Program in FY 1988 was to provide a document describing the development of site-specific DOE LLW radioactive waste classification systems that are based upon performance assessments of intruder scenarios and that comply with the DOE performance objective of 1 imiting doses to intruders. The document was completed (Kennedy and Peloquin 1988) and submitted to the NLLWMP for publication.

\subsection{APPLICATION OF ENGINEERED SORBENT BARRIERS - H. D. Freeman}

The objective of the Engineered Sorbent Barriers Program is to develop and evaluate new and cost-effective technology for restricting the migration of radionuclides from low-level wastes. The technology being evaluated uses sorbent materials in engineered barriers. The primary focus in FY 1988 was to develop a design guide to allow sorbent barrier technology to be applied to any LLW site. In addition, a number of laboratory batch contact tests 
were performed to determine the effectiveness of clinoptilolite, activated carbon, and Savannah River soil in sorbing radioactive strontium, cesium, and cobalt under various conditions.

\subsubsection{Sorbent Barrier Design Guide}

Designing a sorbent barrier is similar to designing a standard waste trench except that the required thickness and the permeability of the sorbent layer must be determined. Figure 4.1 illustrates a typical sorbent barrier as applied to a shallow land burial trench.

The required thickness will depend on the effectiveness of the barrier formulation in sorbing the contaminants. The permeability should be designed to provide enough time for the contaminants to adsorb onto the barrier material, but still allow percolation rates as fast as the annual infiltration rate. Keeping the permeabilities as low as possible also allows the barrier to remain in a near-saturated condition, which promotes sorption.

Several steps must be followed to successfully design an ESB (see Figure 4.2):

1. Characterize the site.

2. Project waste volume and characteristics.

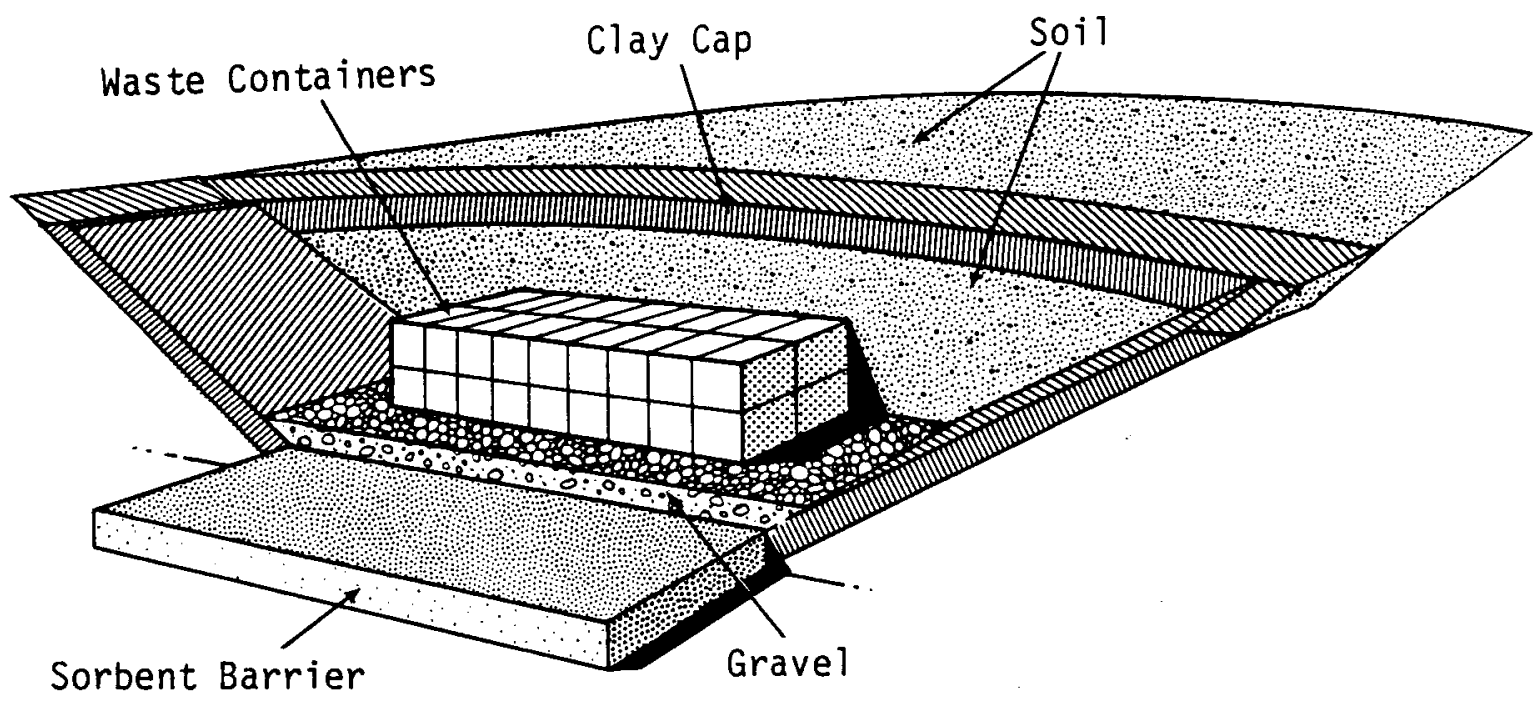

FIGURE 4.1. Conceptual Design of a Sorbent Barrier in a Shallow Land Burial Trench 


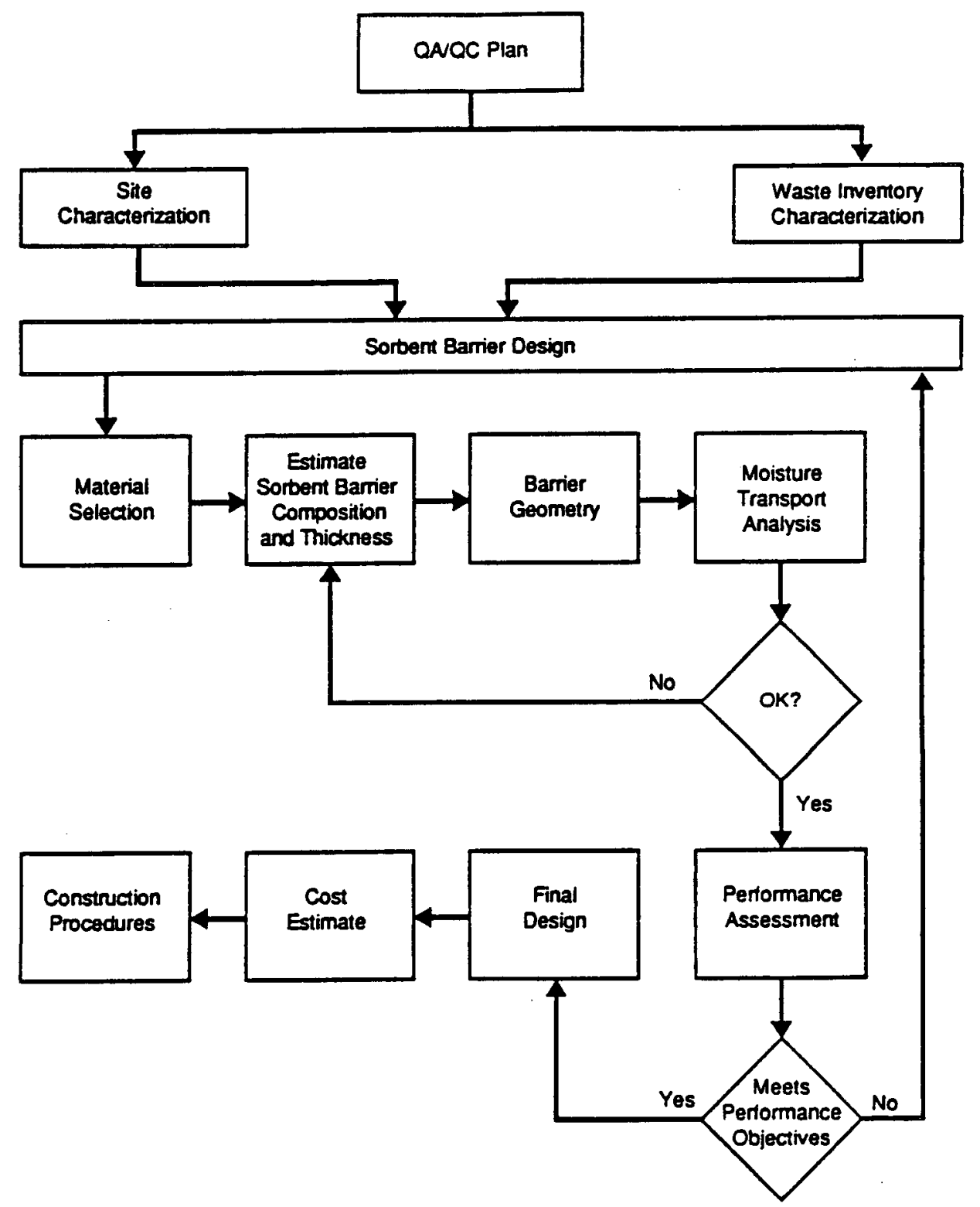

FIGURE 4.2. Basic Design Steps for an Engineered Sorbent Barrier System

3. Select candidate sorbent materials based on waste and groundwater chemistry.

4. Conduct laboratory testing of sorbent materials under expected trench conditions. 
5. Estimate required barrier thickness based on site and waste characteristics and data obtained from laboratory tests and from computer models such as PATHRAE (Rogers and Hung 1987) and UNSAT2 (Davis and Neuman 1983).

6. Estimate construction and material costs based on trench dimensions and barrier thickness.

Each step is briefly described in the following paragraphs.

\subsubsection{Site Characterization}

Site characterization techniques vary from site to site. An example of an approach used earlier is outlined in Davis et al. (1984). In general, for characterizing a candidate site, the parameters should include soil properties such as density, porosity, permeability, and distribution coefficient $\left(K_{d}\right)$; hydrologic characteristics such as depth and flow rates of the aquifer and infiltration rates; climatic conditions; and surface barrier design.

\subsubsection{Projection of Waste Volume and Characteristics}

Sorbent barriers can be tailored to work under a variety of chemical environments. Ideally, the chemical makeup of the waste, the radionuclide inventory, and the expected waste leach rates should be established. Since sorbent barriers are designed primarily for new LLW sites, the waste volumes and compositions must be estimated from previous experience and from projections of expected future activities. Yearly estimates of waste volumes, compositions, and activities for the active life of the LLW site should be obtained so that occupational and offsite exposures can be more accurately projected.

\subsubsection{Selection of Sorbent Materials}

The sorbent material selected for an ESB will provide the most adsorption of contaminant from the leachate relative to the costs of the materials. The leachate composition will depend on the interaction of the infiltrating water and the waste forms. A number of criteria must be applied to select the most appropriate material. Key properties required for a successful barrier include high $K_{d}$ for contaminants in the waste, long-term durability, low cost, availability, and suitable hydraulic properties (i.e., ability to meet the permeability requirements of the barrier). Materials that have been 
tested in the PNL program would provide an excellent starting point for selecting candidate materials for other sites. The materials were evaluated using a leachate composition representative of a humid LLW site: $1 \mu \mathrm{Ci} / \mathrm{L}$ each of ${ }^{60} \mathrm{Co},{ }^{90} \mathrm{Sr}$, and ${ }^{134,137} \mathrm{Cs} ; 100 \mathrm{ppm}$ each of calcium, sodium, and magnesium; and $1 \mathrm{ppm}$ EDTA at a pH of 5 . Table 4.1 provides a partial 1 ist of materials and their $K_{d}$ values as determined with batch contact tests.

The $K_{d}$ values in Table 4.1 are for typical materials selected for sorption of ${ }^{90} \mathrm{Sr},{ }^{137} \mathrm{Cs}$, and ${ }^{60} \mathrm{Co}$. The values for specific site conditions must be measured in the laboratory using the leachate compositions actually expected. The methods for obtaining $K_{d}$ values are described in more detail in the following section.

\subsubsection{Laboratory Testing of Sorbent Materials}

Laboratory testing of applicable adsorbent materials helps to predict the performance of an ESB. The most common laboratory procedures are batch contact tests and column tests.

Batch contact tests are widely used to obtain equilibrium data of the contaminants on the adsorbent. These tests are a relatively fast and inexpensive method for screening candidate materials and assessing the effects of environmental parameters such as $\mathrm{pH}, \mathrm{eH}$, and contact time. These tests combine the adsorbent and the contaminated solution in a closed vessel until the mixture reaches equilibrium. Adsorption curves are generated from a series

TABLE 4.1. Distribution Coefficients of Selected Sorbent Materials

Material
Clinoptilolite, CH Deposit
Clinoptilolite, XY Deposit
Greensand (Glauconite)
Indian Red Pottery Clay
Bentonite
A5l Synthetic Zeolite
Activated Carbon

\section{Material}

Clinoptilolite, CH Deposit

Greensand (Glauconite)

Bentonite

Activated Carbon

\begin{tabular}{|c|c|c|}
\hline \multicolumn{3}{|c|}{$K_{d}, m L / g$} \\
\hline$\underline{\mathrm{C}_{0}}$ & $\mathrm{Sr}$ & $\mathrm{Cs}$ \\
\hline 0 & 1,270 & 4,830 \\
\hline 0 & 558 & 5,140 \\
\hline 0 & 5.9 & 5,150 \\
\hline 131 & 15.8 & 14,700 \\
\hline 109 & 23.6 & 1,830 \\
\hline 216 & 1,720 & 1,100 \\
\hline 995 & 18 & 25 \\
\hline
\end{tabular}


of batch contact tests over a range of contaminant concentrations. However, there is some question about the validity of using batch contact data to predict long-term performance of sorbent materials. Batch contact tests tend to mix particles and solution better than can actually be expected in the field and therefore predict a greater maximum adsorption coefficient than that achieved in the field. In addition, batch contact tests are normally performed under an oxidizing atmosphere (with air), while the atmosphere in the field is normally less oxidizing. Furthermore, the small quantity of material used in a batch contact test may not be representative of the sorbent material as a whole, especially for multicomponent formulations.

Column tests are used to approximate dynamic field performance by flowing contaminated solutions through a column of soil or adsorbent. Flowthrough tests have advantages such as the ability to use larger samples of material and to simulate actual site conditions more closely, in which water percolates through the barrier. The primary product of a column test is the breakthrough curve, which is a plot of contaminant concentration exiting the column as a function of the number of pore volumes of solution passed through the column. The fundamental purpose of the column test is to produce a contaminant breakthrough curve identical to that of the field barrier. A pore volume is the void space in the adsorbent within the column. Column tests provide less useful data as the laboratory conditions depart from the field conditions. Since the actual barrier is expected to contain contaminants for several hundred years, the actual ESB time span cannot be matched in a 1 aboratory experiment. An example of a typical PNL 1aboratory study on sorbent materials for an LLW site is presented in Section 4.3.2.

\subsubsection{Estimating Sorbent Barrier Thickness and Permeability}

Much of the information described in the prior sections is needed for calculating the thickness of the sorbent barrier required to meet performance objectives. The thickness will depend on the effectiveness of the sorbent material, amount and composition of the waste stored in the trenches, leachability of the waste, annual infiltration rates, soil and aquifer properties, and distance to the site boundary. These data are used as input to analytic equations or to a computer model such as PATHRAE (Rogers and Hung 1987) for 
estimating the levels of contaminants at the site boundary. An iterative approach is used with these models to estimate the barrier thickness. The barrier thickness is adjusted until the model indicates that radionuclide levels meet all regulatory 1 imits.

In addition to evaluating the retardation of contaminant migration, it is also important to evaluate the hydraulic behavior of the barrier system to ascertain that the moisture flow patterns will not compromise barrier performance. Simple analytic equations may not be rigorous enough to project the true performance of the barrier. Moisture flow in layered systems comprising materials with dissimilar properties can be difficult to model and may require the use of finite-element or finite-difference models such as UNSAT2 (Davis and Neuman 1983) or similar models. The results of these moisture simulations may indicate that a different layer thickness or configuration may be necessary to meet performance objectives. The preliminary ESB design determined by this process will be incorporated into a detailed configuration for the disposal site. A detailed performance assessment of the whole facility must then be completed to demonstrate compliance with all applicable regulations.

Contaminant Transport Modeling. A computer model, such as PATHRAE, will be used to determine the barrier thickness by simulating the transport of contaminants from the waste to the site boundary. The thickness of the barrier will be adjusted until the calculated dose at the site boundary is within the applicable limits. PATHRAE is a code developed for the U.S. Environmental Protection Agency (EPA) to estimate annual whole-body doses to a critical population group by landfill or incineration methods. PATHRAE is part of a family of codes used by the EPA to generate basic data for environmental impact statements. PATHRAE calculates doses caused by all pathways, including groundwater, surface water, air, and food chain. For shallow land burial sites, groundwater transport typically contributes an overwhelming majority of the total dose. If the applicable standard used is the interim EPA drinking water standard, then the dose limit would be $4 \mathrm{mrem} / \mathrm{yr}$ (EPA 1986). 
PATHRAE uses analytic equations to determine the transient contaminant transport in the saturated (aquifer) and unsaturated (vadose) zones. Major assumptions of PATHRAE are 1) plug flow in the unsaturated zone, 2) decoupling of longitudinal and transverse dispersion in the saturated zone, and 3) no dispersion in the vertical direction of the saturated zone. El iminating dispersion produces conservative estimates of contaminant concentrations since the contaminant is not diluted or dispersed over larger areas. Once the information is gathered, the final results should be checked using simplified analytic equations.

Moisture Transport Modeling. An unsaturated water flow code such as UNSAT2 also can be used to calculate the effect of the water infiltration rate on residence time of leachate in a barrier; this information can be used to determine the required barrier permeability. Laboratory tests would then be run to determine the proper mix of adsorbent and soil. Another advantage of computer codes is the ability to quickly determine the effects of variation in different parameters for a sensitivity analysis.

\subsubsection{Engineered Sorbent Barrier Construction and Costs}

Waste trenches have been employed for decades to store solid low-level radioactive waste. Placing a sorbent material on the bottom of a waste trench would not introduce any new construction techniques or require significant additional labor. The same equipment and procedures used currently would be employed.

The cost of constructing a trench is normally estimated using the volume of excavated soil. The additional cost of laying down a sorbent layer will also be estimated using the volume of material to be applied. The major additional cost of the sorbent barrier will be the raw material. The greatest cost reduction for an ESB wi11 come from 1) reducing the trench volume by using the maximum trench slope and packing the waste containers tightly and 2) by not exceeding the required adequate sorbent barrier thickness.

The procedures for constructing an ESB waste trench will include site preparation, excavation, barrier mixing and installation, compaction, gravel layer installation, and surface contouring/compaction. Once the gravel layer 
is in place, the waste is emplaced, the trench is backfilled, and after the trench is filled, a soil topcover or barrier is installed.

\subsubsection{Laboratory Studies}

Laboratory testing in FY 1988 focused on the adsorption behavior of clinoptilolite and activated carbon with a simulated leachate. Based on previous testing, these adsorbents were chosen as applicable sorbent barrier materials because adsorption performance was good and the cost was relatively low. Clinoptilolite materials from two different mined deposits (referred to as $\mathrm{CH}$ and $\mathrm{XY}$ ) were examined, but only material from one deposit (CH) was used for most of the tests. The simulated leachate in all the tests contained the standard composition of $1 \mu \mathrm{Ci} / \mathrm{L}$ each of ${ }^{85} \mathrm{Sr},{ }^{60} \mathrm{Co}$, and ${ }^{137} \mathrm{Cs} ; 100 \mathrm{ppm}$ each of calcium, sodium, and magnesium ions; $1 \mathrm{ppm}$ of EDTA as a complexing agent; and adjusted solution $\mathrm{pH}$ of 5 . The ions were added to compete with the radionuclides, and EDTA was added to complex the ${ }^{60}$ Co. Normally ${ }^{60} C_{0}$ is not mobile except in the presence of a complexing agent, which acts as a carrier. All tests were performed using both $\mathrm{CH}$ clinoptilolite and activated carbon; the size fraction of clinoptilolite was $-5+35$ mesh, and the activated carbon was used as received from the manufacturer.

Baseline tests were run under the standard conditions for comparison with tests performed in 1986 (Freeman, Mitche11, and Buelt 1986). The activated carbon showed adsorption results very similar to earlier test results, while the $\mathrm{CH}$ deposit of clinoptilolite was more effective than found in previous testing. This increased effectiveness has been attributed to the new $\mathrm{CH}$ clinoptilolite being mined from a deeper portion of the natural deposit. The $\mathrm{XY} \mathrm{Cl}$ inoptilolite did not perform as well as the $\mathrm{CH} \mathrm{Cl}$ inoptilolite and was not tested further. The $\mathrm{CH}$ clinoptilolite was particularly effective in adsorbing ${ }^{85} \mathrm{Sr}$, and the activated carbon was the only effective adsorbent for EDTA-complexed ${ }^{60} \mathrm{Co}$. The ${ }^{137} \mathrm{Cs}$ was strongly adsorbed by most materials.

Several test conditions were varied in batch contact tests:

(a) Ethylenediaminetetraacetic acid. 
- solution $\mathrm{pH}$ - to determine its effect on adsorption

- solid:solution ratio - to construct an adsorption curve

- length of batch contact time - to determine the rate of adsorption

- adsorbent particle size - to alter the rate of adsorption

- type of ions - to identify potential model contaminants.

Each of these areas is described in more detail in the following sections.

\subsubsection{Solution $\mathrm{pH}$}

Clinoptilolite and activated carbon were tested with an initial solution $\mathrm{pH}$ of $1,3,5,7$, and 9 . The adsorption of both clinoptilolite and activated carbon did not vary at $\mathrm{pH}$ of 3 and above. Figure 4.3 shows a typical curve of the $K_{d}$ of ${ }^{85} \mathrm{Sr}$ on clinoptilolite, activated carbon, and bentonite as a function of $\mathrm{pH}$. Since most groundwater will be above a $\mathrm{pH}$ of 3 , the groundwater $\mathrm{pH}$ will have no effect on the adsorption coefficient. The remainder of the tests were performed at a solution $\mathrm{pH}$ of 5 .

\subsubsection{Adsorption Curves}

An adsorption curve is a plot of the amount of ion adsorbed onto the solid adsorbent versus the concentration in the solution (at equilibrium). The $K_{d}$ is the slope of the adsorption curve. Varying the solid:solution ratio changes the amount of contaminant adsorbed from the solution and

Activated Carbon $\square$ Bentonite Clay $\bullet$ Clinoptilolite

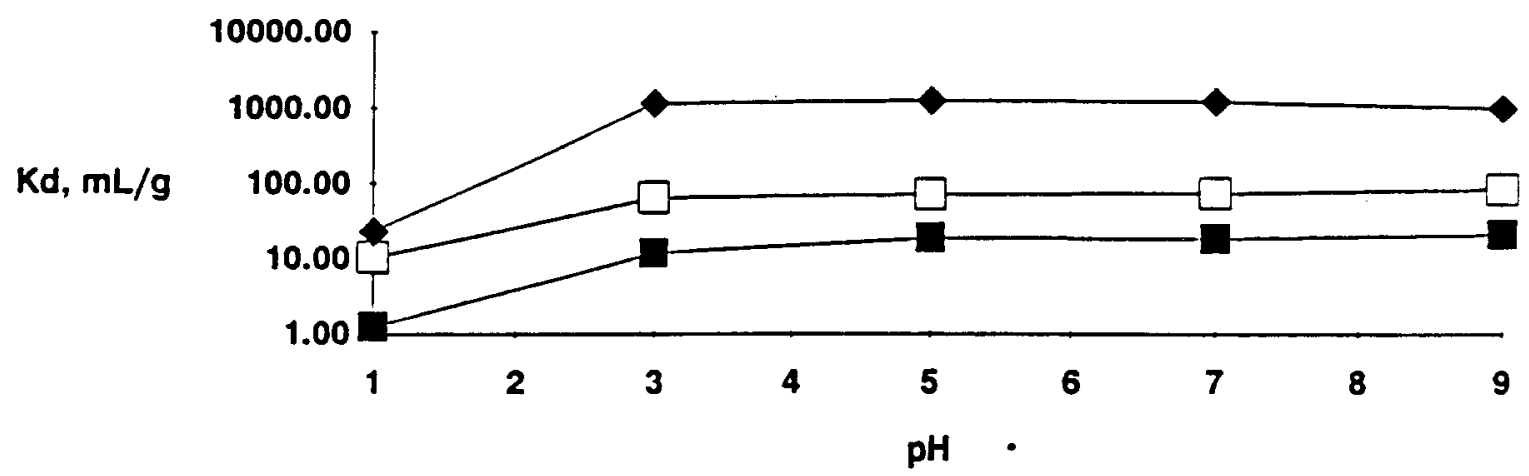

FIGURE 4.3. Effect of $\mathrm{pH}$ on Sorption of ${ }^{85} \mathrm{Sr}$ 
creates different equilibrium solution concentrations. Because all the curves were linear in the low concentration range studied, the use of a constant $K_{d}$ was appropriate when estimating sorption. Figure 4.4 is a typical example of adsorption curves. Those for ${ }^{85} \mathrm{Sr},{ }^{60} \mathrm{Co}$, and ${ }^{137} \mathrm{Cs}$ were linear throughout the expected range of concentrations on both activated carbon and clinoptilolite. Linear adsorption will simplify the groundwater contaminant modeling because the $K_{d}$ will be constant.

Contrasting desorption data were obtained by mixing solids saturated with contaminants with fresh standard solutions. The purpose of these reversibility tests was to determine the amount of contaminants that would desorb from the solid. The desorption data created linear curves similar to
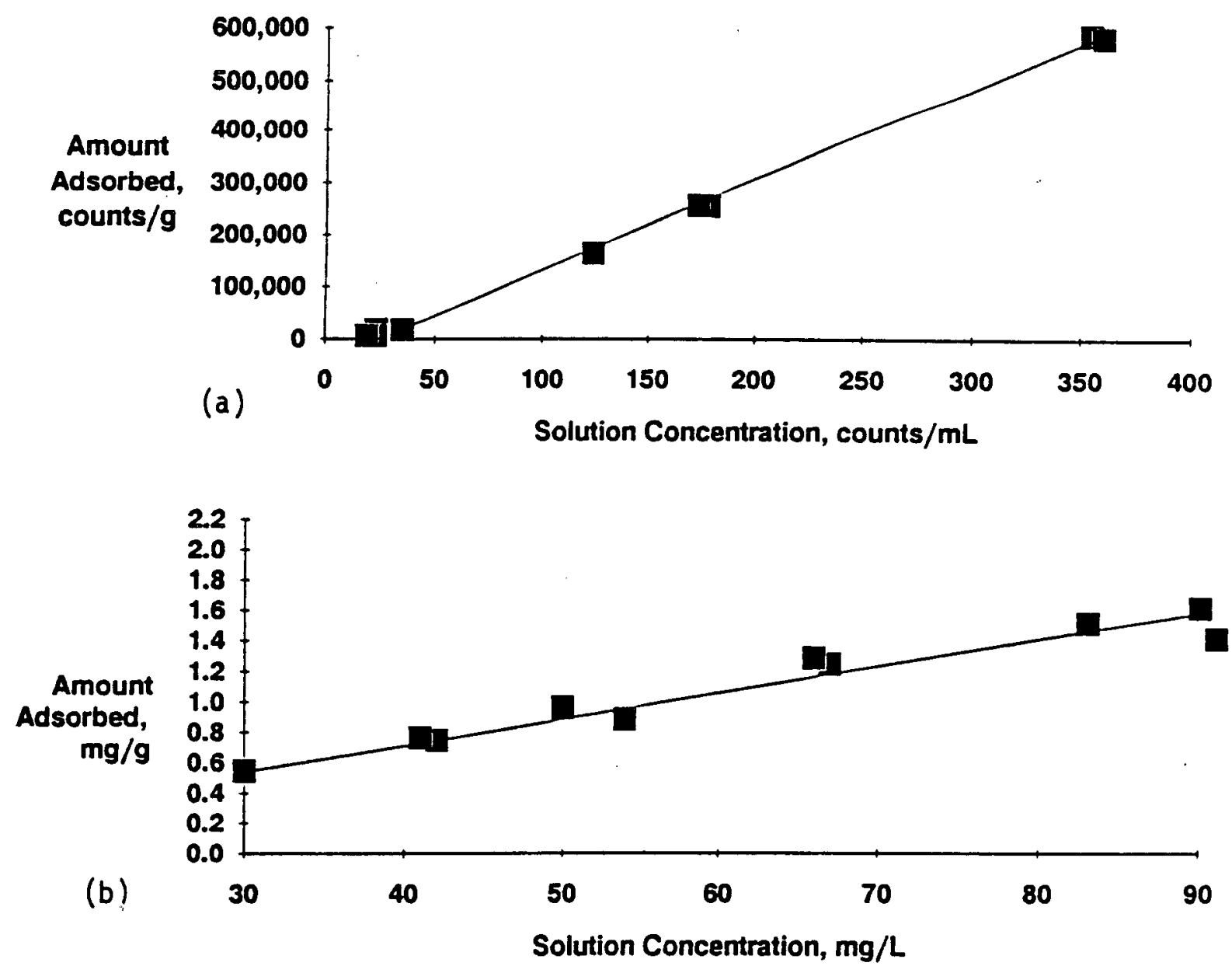

FIGURE 4.4. Typical Adsorption Curve for (a) Strontium and (b) Magnesium 
those of the adsorption data but at lower equilibrium concentrations. In essence, the desorption created additional adsorption data at lower equilibrium concentrations. The reversibility of the adsorption implies that the adsorption mechanism is simply physical adsorption and not irreversible chemisorption.

\subsubsection{Adsorption Kinetics}

The adsorption of ${ }^{85} \mathrm{Sr}$ on clinoptilolite and ${ }^{60} \mathrm{Co}$ on activated carbon required several days to reach equilibrium. This time period contrasts with the instantaneous kinetics assumed when $K_{d}$ values are applied in calculations of radionuclide migration. Figure 4.5 shows the effect of contact time on the $K_{d}$ values for ${ }^{85} \mathrm{Sr}$. Tests were performed at contact times of $0.5,1,4$, $16,72,120$, and $256 \mathrm{hr}$.

The slow adsorption kinetics require that flow-through column tests be run at extremely slow flow rates if equilibrium is to be obtained between the solids and leachate. The kinetics found in this study would require column tests to be run for several years before breakthrough would be observed. Consequently, other methods were examined to identify a method of accelerating column testing. Two alternative methods were investigated for conducting

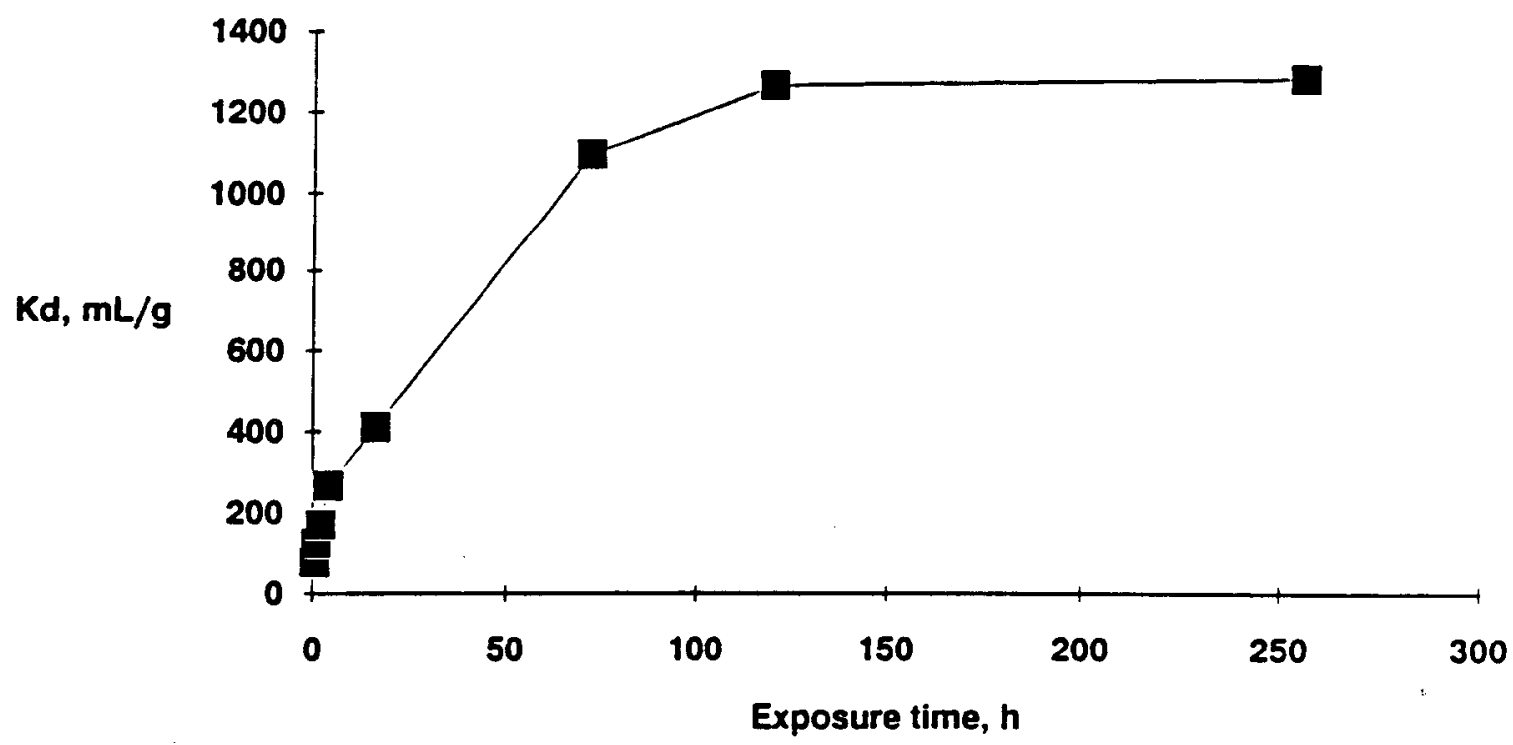

FIGURE 4.5. Effect of Contact Time on ${ }^{85}$ Sr Distribution Coefficient 
the flow-through tests in an equilibrium condition within several months: 1) the use of finely ground material and 2) the use of model contaminants having lower $K_{d}$ values and faster kinetics.

A technique for accelerating column tests, employed by manufacturers of activated carbon, is to use very small particles of adsorbent. The fine particles reduce the path length for interparticle diffusion. The rate of adsorption is increased if the interparticle diffusion controls the overall rate of adsorption. If chemical kinetics are controlling, then reducing the particle size will not increase the adsorption rate.

Batch contact tests were completed with ground and standard-sized clinoptilolite and activated carbon at different solid:solution ratios and contact times. Figure 4.6. shows the effect of particle size on the rate of adsorption. The ground activated carbon ( -200 mesh) had a slightly faster adsorption rate than did the standard-sized activated carbon ( -6 mesh + 16 mesh). The implication is that interparticle diffusion is a significant mechanism for adsorption of ${ }^{60}$ Co $_{0}$ onto activated carbon, al though the relationship is not strong enough to imply that it is the rate-limiting step. The adsorption rate of ${ }^{85} \mathrm{Sr}$ on ground clinoptilolite (-200 mesh) was not altered by the particle size, an indication that the rate of chemical reactions is limiting the adsorption.

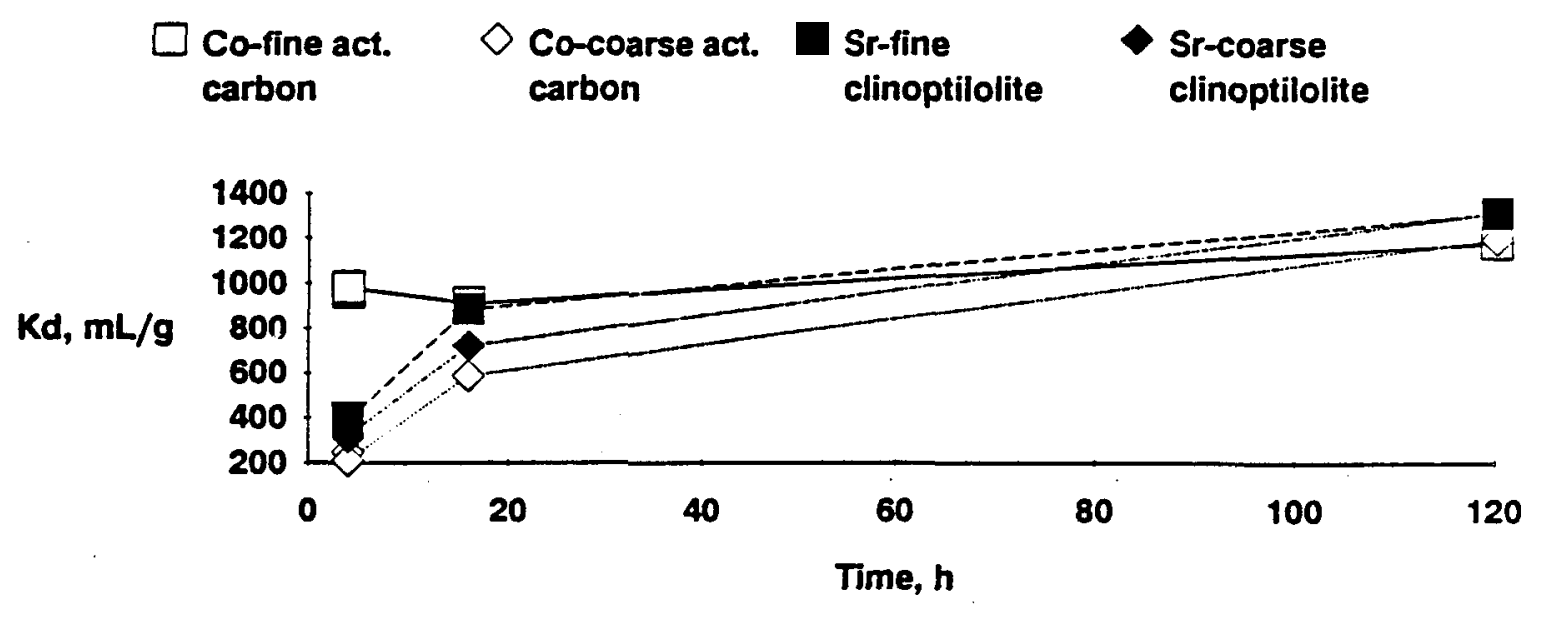

FIGURE 4.6. Effect of Particle Size on Sorption of ${ }^{85} \mathrm{Kr}$ 
Possibly the adsorption of ${ }^{85} \mathrm{Sr}$ onto clinoptilolite follows a series of faster competing ionic adsorption; the adsorption of ${ }^{85} \mathrm{Sr}$ is thermodynamically more stable but occurs at a slower kinetic rate than other competing adsorption. The increased adsorption rate for activated carbon was not high enough to allow this technique to be used for flow-through column tests.

The ions of magnesium, barium, sodium, bromide, copper, and calcium were examined using batch contact tests. The ions were chosen for their chemical similarity to ${ }^{85} \mathrm{Sr}$ or ${ }^{60} \mathrm{Co}$. The most promising ion was magnesium with a low $\mathrm{K}_{\mathrm{d}}$ of 15 to $20 \mathrm{~mL} / \mathrm{g}$ but a slow adsorption rate. Magnesium would be wellsuited for field studies but could not be used in column tests. Figure 4.4 compares adsorption curves of ${ }^{85} \mathrm{Sr}$ and $\mathrm{Mg}^{+2}$ onto clinoptilolite. The amount adsorbed is proportional and linear at all concentrations. The adsorption rate of $\mathrm{Mg}^{+2}$ is slow, requiring $120 \mathrm{hr}$ to reach equilibrium, as with ${ }^{85} \mathrm{Sr}$. No model contaminant with fast adsorption was identified; therefore, column testing was not pursued.

\subsubsection{Conclusion}

Engineered sorbent barriers provide an inexpensive and effective method to give additional radionuclide retention for shallow land burial trenches; they can easily be constructed using existing equipment and procedures. Furthermore, long-term maintenance will not be required. PNL's preliminary design guide will provide guidelines for applying sorbent barrier systems to low-level radioactive waste sites.

Sorbent barriers have other potential applications such as the following:

- a top cover to prevent contaminant uptake from vegetation

- an inner layer within a leachate/liner trench to produce a clean leachate

- a backfill around an above-ground or below-ground vault to prevent release of contaminants should a breach occur in the primary container. 


\subsection{SPECIAL WASTE FORM LYSIMETERS - ARID - T. L. Jones}

In 1983, the Special Waste-Form Lysimeters - Arid Program was initiated at PNL to study the release of radionuclides from commercial solidified waste forms. The program consists of both laboratory- and field-scale testing. The laboratory effort has studied the release of solutes from small samples using "breaker" tests such as the ANS.16.1 leach tests and flow-through column tests (Walter, Graham, and Gee 1984). The field-scale program has centered around a lysimeter facility (Walter et al. 1986) where ten 200-L samples were buried in soil and allowed to be leached by water from natural precipitation. The release of chemicals from the field samples is being studied by analyzing the drainage water collected from the bottom of the lysimeters.

Two topical reports were issued during FY 1988. The first (Criscenti and Serne 1988) summarizes efforts to use the geochemical model MINTEQ (Peterson et a7. 1987) to analyze the laboratory leaching tests. Effluents from the batch and column leach tests were evaluated by MINTEQ to identify possible solid phases that may be controlling solution concentrations. The second report (Jones, Serne, and Toste 1988) issued in FY 1988 summarizes the field data collected at the lysimeter facility from March 1984 to early 1987. These field data include the quantities of radionuclides and major nonradioactive constituents that have leached from the waste forms. The report also includes an analysis of the water balance of the lysimeters, including soil water contents and drainage rates.

\subsubsection{Geochemical Modeling of Laboratory Leach Tests}

Laboratory experiments were conducted by PNL to 1) investigate the performance of solidified LLW in a typical arid, near-surface disposal site and 2) evaluate the ability of 1aboratory tests to predict leaching in actual field conditions. Batch leaching, soil adsorption column, and soil/waste form column experiments were conducted using Portland III cement waste forms containing boiling-water reactor evaporator concentrate and ion-exchange resin waste (Walter et al. 1986). To understand the reaction chemistry of the cement waste form/soil/groundwater system, the compositions of the 
leachates from the laboratory experiments were studied with the aid of the MINTEQ ion speciation/solubility and mass transfer computer code.

Compositional analyses for leachates from the following experiments were available: 1) batch leaching experiments, in which either Portland III cement or Portland III cement mixed with the waste stream was placed in contact with groundwater; 2) soil adsorption column experiments, in which either ground- water or leachate from the batch experiments contacted soil; and 3) soil/waste form column experiments, in which either a blank or a real waste form was buried in soil and exposed to groundwater as it passed through the columns. MINTEQ calculations were performed on the leachate compositions to examine the ion speciation of calcium, magnesium, silicon, boron, $\mathrm{CO}_{3}$, $\mathrm{SO}_{4}$, and $\mathrm{PO}_{4}$ in solution and to evaluate potential solubility controls for these components.

The results indicate that interaction with either Portland III cement or a cement waste form alters the groundwater composition. The effects of the waste on the leachate composition are significant during the initial contact period but decrease with continued waste form/groundwater interaction. The initial effects were an increase in $\mathrm{pH}$ from $\sim 8$ to between 10 and 12 , an increase in alkalinity, and an increase in concentrations of sodium, potassium, $\mathrm{SO}_{4}, \mathrm{PO}_{4}$, and organic carbon. These effects were observed in both the batch leaching and soil/waste form column experiments; they were not observed in either batch soil adsorption column experiments, probably because the leachates from the batch experiments were mixed together before being added to the soil. The major changes in component speciation that result from the presence of the waste are an increase in phosphate- and sodium-bearing species. Minerals that are likely to precipitate to form a reaction rim around the waste form include calcite, dolomite, sepiolite, and quartz. The precipitation of these minerals would maintain the low concentrations of calcium, magnesium, and silicon observed in the leachates. A similar examination of the leachates from the field lysimeters, which are currently being monitored as part of the Special Waste Form Lysimeters - Arid Program, would be useful to indicate whether their major element concentrations are controlled by the same geochemical processes as those of the leachates obtained in the laboratory tests. 


\subsubsection{Lysimeter Data}

The water balance of the field lysimeter during FY 1988 has proceeded similarly to previous years. Table 4.2 summarizes the individual water balance components. The total amount of precipitation was down from $14.5 \mathrm{~cm}$ in FY 1987 to $11.7 \mathrm{~cm}$ in FY 1988; precipitation during both years was below the long-term average for Hanford, $-16 \mathrm{~cm} /$ year. The amount of drainage from the bare-surface lysimeters was $3.7 \mathrm{~cm}$ in FY 1988, which is $32 \%$ of the total precipitation received. The amount returned to the atmosphere through evaporation was $56 \%$. Both of these percentages are consistent with previous years. The only year when significantly more than $30 \%$ of the precipitation ended up as drainage was FY 1986, when the amount of snow received was unusually large; precipitation received in the winter months as snow has a greater probability of becoming drainage water than does spring or summer rain water.

The cumulative release of tritium and ${ }^{60} \mathrm{Co}_{0}$ from the lysimeters is shown in Figures 4.7 and 4.8 , respectively. The cumulative microcuries of radionuclides found in lysimeter drainage is plotted against the cumulative drainage. The release of tritium appears to be a linear function of the amount of water draining from the lysimeters. The waste forms in lysimeters 1 and 7 are the only waste forms containing tritium, and through 1988 they

TABLE 4.2. Average Water Balance Parameters, cm

Parameter

Tota
Snow a) precipitation $(a)$

Change in storage

Drainage

Evaporation

Range of water content, $\mathrm{cm} / \mathrm{m}$

$$
\text { 9-1-86 to } 8-31-87
$$

14.5

21.3

$2.1 \pm 1.8$

$5.3 \pm 0.7$

$7.1 \pm 1.6$

$7.0-9.3$
9-1-87 to $8-31-88$

\section{7}

29.5

$1.6 \pm 0.7$

$3.7 \pm 0.3$

$6.5 \pm 0.7$

$6.8-8.5$

(a) Hanford Meteorological Station 


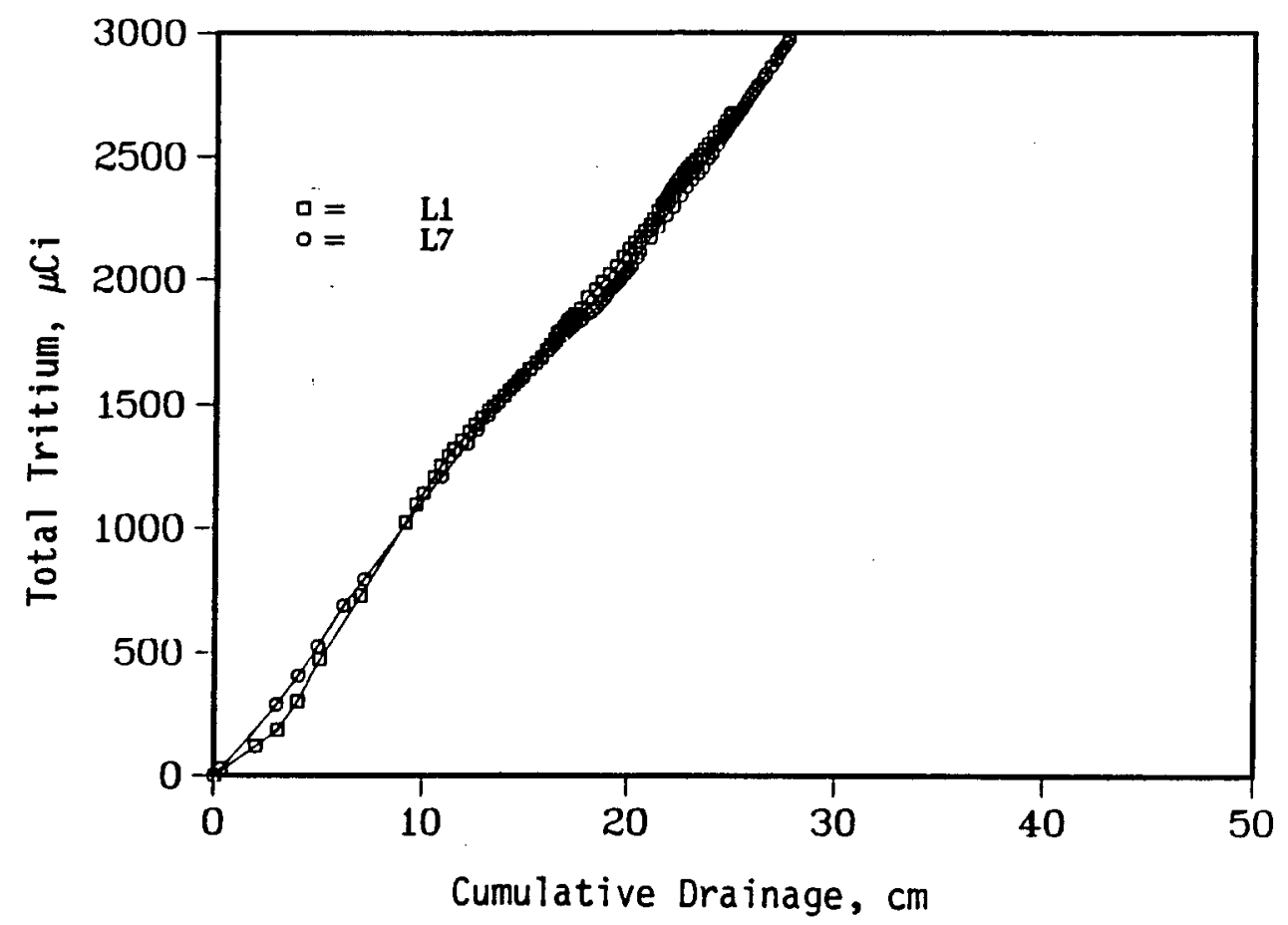

FIGURE 4.7. Cumulative Release of Tritium from Lysimeters

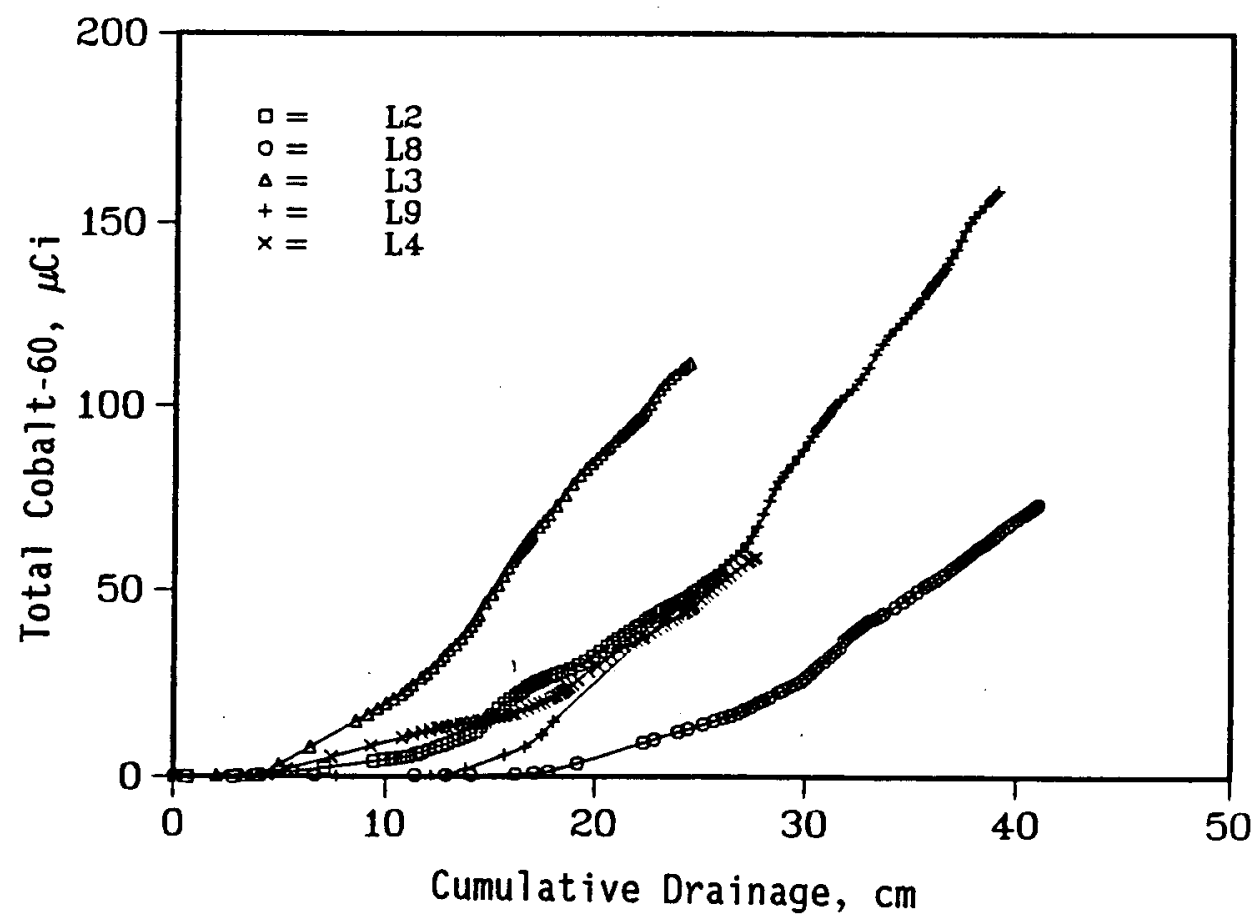

FIGURE 4.8. Cumulative Release of ${ }^{60}$ Co from Lysimeters 
have released $54 \%$ and $59 \%$ of their respective inventories. The rate of release has remained fairly constant at $\sim 106 \mathrm{mCi}$ of tritium per centimeter of water drained.

The release of ${ }^{60}$ Co can also be related to the amount of water passing through the lysimeters, though not linearly. While the absolute amount of ${ }^{60}$ Co being released from the lysimeters has decreased during FY 1987 and FY 1988, the amount of cobalt released per unit of drainage water has increased by $80 \%$ in lysimeters 2 and $8,30 \%$ in lysimeters 3 and 9 , and by nearly $300 \%$ in lysimeter 4 . Only trace amounts of ${ }^{60}$ Co have been detected in leachate from lysimeter 10 . Lysimeters 2, 8, 3, and 9 contain concrete waste forms while lysimeters 4 and 10 contain polymer waste forms. No radionuclides have been detected in leachate from lysimeters 5 and 6 , which contain bitumen waste forms. The total amount of cobalt that has been released from the lysimeters is still less than $0.1 \%$ of the ${ }^{60} \mathrm{Co}_{0}$ inventory. Therefore, the fraction of ${ }^{60}$ Co mobile in the soil appears to be a small percentage of the total ${ }^{60}$ Co contained in the waste forms.

\subsection{DOCUMENTATION OF INTRUDER SCENARIOS USED TO DEVELOP SITE-SPECIFIC DOE} LLW CLASSIFICATION SYSTEMS - W. E. Kennedy, Jr.

During FY 1988, DOE was in the process of revising DOE 5820.2, Chapter III (DOE 1988), which concerns defense LLW management. The revised Order describes the purpose, policy, and requirements necessary for managing and disposing of defense LLW. The DOE policy calls for LLW operations to be conducted in a manner that protects the health and safety of the public, preserves the environment, and ensures that no remedial actions will be necessary after operations are terminated. The basic approach used by DOE is to estabiish overall performance objectives in terms of groundwater protection and public radiation dose limits and to require site-specific performance assessments to determine compliance. As a result of these performance assessments, each site will develop waste acceptance criteria that define the allowable disposal quantities and concentrations of specific radioisotopes. Additional limitations on waste disposal design, waste form, and waste treatment will also be developed on a site-specific basis. 
As a key step in the site-specific performance assessments, potential radiation doses had to be evaluated for intruders who may inadvertently move onto a closed DOE LLW disposal site after loss of institutional controls. The purpose of this study was to provide a document supporting the revised DOE Order that describes the development of site-specific DOE LLW radioactive waste classification systems using a performance assessment of intruder scenarios and compliance with the DOE performance objective limiting doses to intruders. Radiological performance assessment is defined as "a systematic analysis of a LLW treatment, storage, or disposal facility and its local environment for purposes of demonstrating compliance with the performance objectives" (Case and Otis 1988). This working definition does not address the nonradiological components of LLW (because they are assumed to be covered under other DOE Orders), and it does not address worker protection. The document was produced (Kennedy and Peloquin 1988) and submitted to the NLLWMP for publication.

The analysis of intruder scenarios during the performance assessment is useful in setting site-specific limits on waste concentration, whereas analysis of transport through groundwater is useful in setting site inventory limits. Concentration limits set by intruder scenarios are intended to be used along with practical consideration of the waste form and disposal design to establish site-specific waste classification systems. The steps in this part of the performance assessment include 1) establishing the site-specific scenarios, parameters, and assumptions, 2) performing draft calculations for unit concentrations of selected radionuclides, and 3) performing an "inversetype" calculation to establish what waste concentrations would be permitted at burial time in order to meet intruder dose performance objectives at the assumed intrusion time.

When considering human-intrusion scenarios, an effort should be made to match the scenarios considered with the site-specific disposal and waste form conditions encountered. This means that scenarios must be considered in addition to those identified by the U.S. Nuclear Regulatory Commission (NRC) in their analysis supporting 10 CFR Part 61 (NRC 1986). A generic evaluation of scenarios was also conducted for long-lived radionuclides by an Expert 
Group to the Nuclear Energy Agency of the Organization for Economic Cooperation and Development (NEA/OECD 1987). However, the scenarios considered did not differ significantly from those considered by the NRC.

The human intrusion scenarios considered by the NRC and NEA/OECD, and most scenarios involving human intrusion, are deterministic. This means that they are assumed to occur with no probability assigned to their occurrence. It also means that each scenario may be controlled by additional key assumptions concerning the waste dilution and environmental transport. These assumptions may cause an overestimate or underestimate of actual future conditions. However, this approach is justified by the lack of long-term probabilistic data that would permit the use of more sophisticated probabilistic methods. Computerized models are available from the NRC that permit rapid calculation of radiation doses for a wide variety of intruder scenarios (Oztunali and Roles 1986; Kennedy et a1. 1987).

The following sections briefly summarize the important sections contained in the supporting document produced in the study by PNL.

\subsubsection{Performance Objectives for LLW Disposal}

The performance objectives adopted by the DOE in 5820.2A, Chapter III, for LLW disposal (DOE 1988) are as follows:

1. Protect public health and safety in accordance with standards specified in applicable EH Orders and other DOE Orders.

2. Assure that external exposure to the waste and concentrations of radioactive material that may be released into surface water, groundwater, soil, plants and animals results in an effective dose equivalent that does not exceed $25 \mathrm{mrem} / \mathrm{yr}$ to any member of the public. Releases to the atmosphere shall meet the requirements of 40 CFR 61. Reasonable effort should be made to maintain releases of radioactivity in effluents to the general environment as low as is reasonable achievable.

3. Assure that the committed effective dose equivalents received by individuals who inadvertently may intrude into the facility after the loss of active institutional control (100 years) will not exceed $100 \mathrm{mrem} / \mathrm{yr}$ for continuous exposure or $500 \mathrm{mrem}$ for a single acute exposure.

4. Protect groundwater resources, consistent with federal, state and local requirements. 


\subsubsection{Review of Intruder Scenarios}

Intruder scenarios have been developed and applied in a number of previous national and international LLW assessments. Of particular note are the human-intrusion scenarios for near-surface wastes developed by the NRC supporting the commercial LLW classification system (NRC 1981) and additional scenarios for intruder-resistant wastes developed for the Hanford Defense Waste Environmental Impact Statement (DOE 1987). Because of the variability between waste forms, engineered systems, and environmental conditions at DOE LLW disposal sites, it is difficult to identify generic scenarios that apply universally to all sites. However, broad scenarios can be identified for further site-specific consideration with the understanding that they may be modified to include the best available site data. The following paragraphs contain brief discussions of human-intrusion scenarios that have been identified in previous studies, recognizing that additional scenarios may have to be further defined to account for unique conditions encountered at real sites.

\subsubsection{10 CFR 61 Intruder Scenarios}

The NRC considered three basic human intrusion scenarios that defined their commercial waste classification system (1986): 1) intruderconstruction, 2) intruder-discovery, and 3) intruder-agriculture. For setting their Class $A$ and $C l a s s ~ C$ waste classification limits, the more restrictive of scenarios 1 and 3 (by radionuclide) was used. Scenario 2 was used for setting the Class B limits. A summary description of the intruderconstruction and intruder-agriculture scenarios follows.

Intruder-Construction Scenario. The NRC assumed that this scenario would occur after the shutdown of operations at a commercial LLW disposal facility. Institutional controls are assumed to break down (temporarily), and an intruder inadvertently constructs a house on the disposal facility. The NRC assumed that the intruder contacts the disposed wastes while excavating to construct a basement for the house. This construction work is assumed to last for 500 working hours, or the equivalent of a 3-month construction period. For the analysis of DOE wastes, the acute exposure performance objective of 500 mrem effective dose equivalent is used. The NRC 
represented the basement by a hole $3 \mathrm{~m}$ deep with bottom surface area of $20 \mathrm{~m}$ $\times 10 \mathrm{~m}\left(200 \mathrm{~m}^{2}\right)$ and a top surface area of $26 \mathrm{~m} \times 16 \mathrm{~m}\left(416 \mathrm{~m}^{2}\right)$, giving a $1: 1$ slope for the side of the excavation. The volume of the excavation is equal to $906 \mathrm{~m}^{3}$. The NRC further assumed that the cover material placed over the waste during disposal operations was $2 \mathrm{~m}$ thick for a volume of $675 \mathrm{~m}^{2}$, or about $75 \%$ of the volume of the entire excavation. Dose estimates were provided by the NRC using a simple equation that described the inhalation and external exposure pathways. The NRC provided further assumptions about the air concentration and post-disposal decay period, and allowed optional factors to account for the differences between random and stacked wastes in the trenches and the differences between optional waste forms.

Intruder-Agriculture Scenario. For this scenario, the NRC assumed that an intruder inadvertently lives in the house constructed during the intruderconstruction scenario. He also consumes food grown on the disposal site. The farming activities are assumed to occur in the waste/soil mixture excavated during basement construction. The NRC considered three major pathways for this scenario: 1) inhalation of air contaminated by the resuspended waste/soil mixture, 2) ingestion of garden products grown in the contaminated waste/soil mixture, and 3) direct exposure to gamma radiation. For the analysis of DOE wastes, the long-term performance objective of $100 \mathrm{mrem} / \mathrm{yr}$ effective dose equivalent is used. The NRC provided assumptions concerning the duration of exposure, the air concentration, and the quantity of food raised on the site. They further defined specific factors that account for shielding, post-disposal decay, and optional factors that account for differences among waste forms and are used to modify the radiation dose analysis.

\subsubsection{Additional Intruder Scenarios}

In addition to varying parameters and assumptions based on site-specific conditions, the types of intruder scenarios considered may also vary depending on the wastes, engineering methods, and environmental conditions. For example, if wastes are processed into a special form (designed to resist human intrusion) or if they are buried at depths greater than $5 \mathrm{~m}$, the intruder scenarios defined by the NRC for surface excavation may not directly apply. This type of disposal may resemble "Greater Confinement Disposal" 
operations for LLW disposal that are currently used or planned for future use at many DOE sites. Two scenarios that should apply to most sites and disposal systems are the drilling and post-drilling scenarios that were considered in Disposal of Hanford Defense High-Level, Transuranic and Tank Wastes - Environmental Impact Statement (DOE 1987). A brief discussion of these scenarios follows.

Drilling Scenario. Drilling through buried LLW means to penetrate the waste, remove, and transport the waste and soil material to the land surface. Drilling can occur during the exploration for natural resources (i.e., oil, gas, or water) or as part of site characterization as required by the Comprehensive Environmental Response, Compensation, and Liability Act (CERCLA) or the Resource Conservation and Recovery Act (RCRA). Drilling is likely to penetrate the waste zone at all shallow-land burial sites, independent of the waste form, engineered barrier, or near-surface depth. The use of monuments, barriers, or markers can reduce the likelihood of drilling, but they cannot preclude it. The total volume of waste brought to the surface during drilling is a function of the drill core diameter, the thickness of the waste disposal zone, and the time after disposal that drilling is assumed to occur. For example, if a water well of $0.3 \mathrm{~m}$ diameter is drilled through a 5-m-thick waste zone, the volume of waste brought to the surface is about $0.35 \mathrm{~m}^{3}$. This waste volume can expose the drilling crew through two major pathways: inhalation of resuspended material and direct exposure to penetrating radiation. The air concentration, dilution with non-active soils, and exposure duration will all be functions of site-specific conditions and the drilling method used. For the analysis of DOE wastes, the acute exposure performance objective of $500 \mathrm{mrem}$ effective dose equivalent is used.

Post-Drilling Scenario. The post-drilling scenario is similar to the intruder-agriculture scenario defined by the NRC because it considers the long-term exposures that result after wastes have been mixed with surface soils. This scenario has three major exposure pathways: inhalation of resuspended material, direct exposure to penetrating radiation, and ingestion of contaminated vegetables grown on the site. For this scenario, the volume (and quantity) of waste brought to the surface by the drilling scenario is 
assumed to be diluted with surface soil and spread around the site. Previous studies have considered uniform mixing of the wastes with the soil in the plow layer (the top $15 \mathrm{~cm}$ of soil) and distribution over a $2500 \mathrm{~m}^{2}$ area. Roughly $25 \%$ of an individual's diet could be grown in this area of contaminated soil. The individual is further assumed to spend a major portion of the year (up to 6 months) residing on the site. For the analysis of DOE wastes, the long-term performance objective of $100 \mathrm{mrem} / \mathrm{yr}$ effective dose equivalent is used.

\subsubsection{Discussion}

In establishing site-specific performance assessment scenarios for LLW disposal, attempts should be made to assure that the scenarios are representative of the likely events for the specific waste form and disposal technology encountered. The scenarios briefly described in the report produced for this study (Kennedy and Peloquin 1988) are intended to provide guidance concerning the potential categories of generic scenarios that have been considered in previous studies. The report al so provides example calculations useful in setting site-specific waste classification systems. The information in the report should provide useful guidance supporting DOE 5820.2A, Chapter III.

\subsection{REFERENCES}

Case, M. J., and M. D. Otis. 1988. Guidelines for Radiological Performance Assessment of DOE Low-Level Radioactive Waste Disposal Sites. D0E/LLW-62T, EG\&G Idaho, Inc., Idaho Falls, Idaho.

Criscenti, L. J., and R. J. Serne. 1988. Geochemical Analys is of Leachate from Cement/Low-Level Radioactive Waste/Soil Systems. PNL-6544, Pacific Northwest Laboratory, Richland, Washington.

Davis, E. C., et al. 1984. Site Characterization Techniques Used at a LowLevel Waste Shall ow Land Burial Field Demonstration Facility. ORNL/TM9146, Oak Ridge National Laboratory, Oak Ridge, Tennessee.

Davis, L. A., and S. P. Neuman. 1983. Documentation and User's Guide: UNSAT2-Variably Saturated Flow Model. NUREG/CR-3390, U.S. Nuclear Regulatory Commission, Washington, D.C. 
Freeman, H. D. 1987. "Economic Analysis of Engineered Sorbent Barrier Technology." In Proceedings of the Ninth Annual DOE Low-Level Radioactive Waste Management Conference. CONF-870859-17, August 25-27, 1987, Denver, Colorado.

Freeman, H. D., S. J. Mitche11, and J. L. Bue1t. 1986. Engineered Sorbent Barriers for Low-Level Waste Disposal. PNL-6051, Pacific Northwest Laboratory, Richland, Washington.

Jones, T. L., R. J. Serne, and A. P. Toste. 1988. Special Waste-Form Lysimeters-Arid: Three-Year Monitoring Report. PNL-6400, Pacific Northwest Laboratory, Richland, Washington.

Kennedy, W. E., Jr., R. A. Peloquin, B. A. Napier, and S. M. Neuder. 1987. Intruder Dose Pathway Analysis for the Onsite Disposal of Radioactive Wastes: The ONSITE/MAXI1 Computer Program. NUREG/CR-3620 (Supplement 2). U.S. Nuclear Regulatory Commission, Washington, D.C.

Kennedy, W. E., Jr., and R. A. Peloquin. 1988. Intruder Scenarios for SiteSpecific Low-Level Radioactive Waste Classification. DOE/LLW-71T (PNL6718), Pacific Northwest Laboratory, Richland, Washington.

Licensing Requirements for Land Disposal of Radioactive Waste. 1986. 10 CFR Part 61, Washington, D.C.

Nuclear Energy Agency of the Organization for Economic Cooperation and Development (NEA/OECD). 1987. Shallow Land Disposal of Radioactive Waste: Reference Levels for the Acceptance of Long-Lived Radionuclides. A report by an NEA Expert Group, Paris, France.

Oztunali, 0. I., and G.W. Roles. 1986. Update of Part 61 Impacts Analys is Methodology. NUREG.CR-4370, Vol. 1, U.S. Nuclear Regulatory Commission, Washington, D.C.

Peterson, S. R., B. E. Opitz, M. J. Graham, and L. E. Eary. 1987. An Overview of the Geochemical Code MINTEQ: Applications to Performance Assessment for Low-Level Wastes. PNL-6112, Pacific Northwest Laboratory, Richland, Washington.

Resource Conservation and Recovery Act (RCRA) of 1976. 42 USC 6901 et seq. as amended.

Rogers, V., and C. Hung. 1987. Model Documentation PATHRAE-EPA Methodology and Users Manual. EPA 520/1-87-028, U.S. Environmental Protection Agency, Washington, D.C.

U.S. Department of Energy. 1987. Final Environmental Impact Statement: Disposal of Hanford Defense High-Level, Transuranic and Tank Wastes. D0E/EIS-0113, Vol. 1, Chapters 3 and 5, and Vol. 3, Appendices M and R, Richland, Washington. 
U.S. Department of Energy. 1988. Radioactive Waste Management. DOE 5820.2A, September 1988, Washington, D.C.

U.S. Environmental Protection Agency. 1986. National Interim Primary Drinking Water Standards. 40 CFR Part 141, Washington, D.C.

U.S. Nuclear Regulatory Commission. 1981. Draft Environmental Impact Statement on 10 CFR 61, "Licensing Requirements for Land Disposal of Radioactive Waste." NUREG-0782, Vols, 1-4, Washington, D.C.

U.S. Nuclear Regulatory Commission. 1986. Licensing Requirements for Land Disposal of Radioactive Waste. Washington, D.C.

Walter, M. B., M. J. Graham, and G. W. Gee. 1984. A Field Lysimeter Facility for Evaluating the Performance of Commercial Solidified Low-Level Waste. PNL-5253, Pacific Northwest Laboratory, Richland, Washington.

Walter, M. B., R. J. Serne, T. L. Jones, and S. B. Mclaurine. 1986. Chemical Characterization, Leach, and Adsorption Studies of Solidified LowLevel Wastes. PNL-6047, Pacific Northwest Laboratory, Richland, Washington. 


\section{DISTRIBUTION}

No. of

Copies

OFFSITE

12 DOE/Office of Scientific and Technical Information

2 DOE Office of Civilian

Radioactive Waste Management Forrestal Building Washington, DC 20585

ATTN: S. Rousso, RW-10

R. Stein, RW-30

2 DOE Office of Defense Waste \& GTN

Transportation Management

Washington, DC 20545

ATTN: K. A. Chacey, DP-123

T. B. Hindman, DP-12

4 DOE Office of Remedial Action GTN

\& Waste Technology

Washington, DC 20545

ATTN: J. E. Baublitz, NE-20

J. A. Coleman, NE-24

T. W. McIntosh, NE-24

H. F. Walter, NE-24

A. T. Clark

Division of Fuel Material Safety Nuclear Regulatory Commission

Washington, DC 20555

V. Stello

Office for the Executive

Director for Operations

Mail Station 17-G21

Nuclear Regulatory Commission

Washington, DC 20555
No. of

Copies

Sheldon Meyers

Environmental Protection Agency

Office of Radiation Programs

(ANR-458)

401 M Street S.W.

Washington, DC 20460

P. A. Saxman

DOE Albuquerque Operations Office P.0. Box 5400

Albuquerque, NM 87185

E. Maestas

DOE West Valley Project

P.0. Box 191

West Valley, NY 14171

3 DOE Idaho Operations office

785 DOE Place

Idaho Falls, ID 83402

ATTN: C. R. Enos

M. W. Shupe

J. E. Solecki

F. T. Fong

DOE San Francisco Operations

1333 Broadway

Oakland, CA 94612

M. R. Jugan

DOE Oak Ridge Operations office

P.0. Box E

Oak Ridge, TN 37830

W. T. Goldston

DOE Savannah River Operations Office

P.0. Box A

Aiken, SC 29801 
No. of

Copies

M. J. Steindler

Argonne National Laboratory

9700 South Cass Avenue

Argonne, IL 60439

C. S. Abrams

Argonne National Laboratory

P.0. Box 2528

Idaho Falls, ID 83401

3 Battelle Memorial Institute

Project Management Division

505 King Avenue

Columbus, $\mathrm{OH} \quad 43201$

ATTN: W. A. Carbeiner

R. A. Nathan

Technical Library

L. D. Ramspott

Lawrence Livermore National

Laboratory

University of California

P.0. Box 808

Livermore, CA 94550

D. T. 0akley, MS-J521

Los Alamos National Laboratory

P.0. Box 1663

Los Alamos, NM 87545

4 Oak Ridge National Laboratory

P.0. BoX $Y$

Oak Ridge, TN 37830

ATTN: W. D. Burch

R. T. Jubin

L. J. Mezga

D. W. Turner

2 Sandia Laboratories

P.0. Box 5800

Albuquerque, NM 87185

ATTN: R. W. Lynch

Technical Library
No. of

Copies

J. R. Berreth

Westinghouse Idaho Nuclear

Co., Inc.

P.0. Box 4000

Idaho Falls, ID 83401

5 Westinghouse Savannah River

Company

Savannah River Site

Aiken, SC 29801

ATTN: R. G. Baxter

M. D. Boersma 77341A

J. R. Knight 773A

M. J. Plodinec 773A

C. T. Randal1 7042

A. D. Rodgers

MaiT Stop 2411

EG\&G Idaho

P.0. Box 1625

Idaho Falls, ID 83415

R. Shaw

Electric Power Research Institute

3412 Hillview Avenue

P.0. Box 10412

Palo Alto, CA 94303

4 West Valley Nuclear Services Company

P.0. Box 191

West Valley, NY 14171

ATTN: R. R. Borisch

J. Buggy

J. M. Pope

R. A. Thomas

J. L. White, Chairman

Energy Research \& Development Authority

Empire State Plaza

Albany, NY 12223 
No. of

Copies

ONSITE

6 DOE Richland Operations Office

M. J. Furman

R. E. Gerton

E. C. Norman

J. C. Peschong

S. M. Prestwich

G. W. Rosenwald

7 Westinghouse Hanford Company

J. M. Henderson

T. L. Jones

R. E. Lerch

J. L. Scott

R. A. Smith

D. D. Wodrich

B. A. Wolfe

39 Pacific Northwest Laboratory

C. R. Allen

R. P. Allen

S. 0. Bates

W. F. Bonner

L. A. Bray
No. of

Copies

Pacific Northwest Laboratory (contd)

R. A. Brouns

G. H. Bryan

J. L. Buelt

H. C. Burkholder (5)

C. C. Chapman

M. L. Elliott

H. D. Freeman

R. W. Goles

F. E. Haun

W. 0 . Heath

L. K. Holton, Jr.

$Y$. B. Katayama

W. E. Kennedy

J. L. McElroy

G. B. Mellinger

R. F. Nakaoka

J. M. Perez, Jr.

R. D. Peters

J. A. Powell

W. A. Ross

J. M. Seay

S. C. Slate

J. E. Surma

J. H. Westsik

Publishing Coordination

Technical Report Files

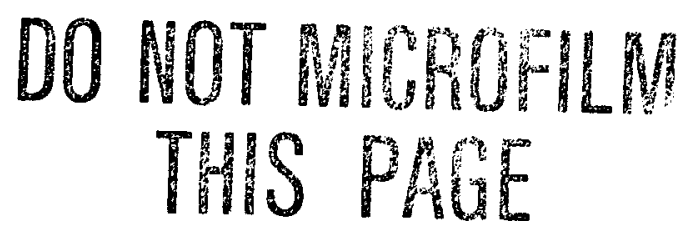

Distr.3 